ZENTRUM

FÜR BIODIVERSITÄT UND NACHHALTIGE LANDNUTZUNG

SEKTION

BIODIVERSITÄT, ÖKOLOGIE UND NATURSCHUTZ

- CENTER FOR BIODIVERSITY AND SUSTAINABLE LAND USE-

SECTION: BIODIVERSITY, ECOLOGY AND NATURE CONSERVATION

\title{
"Effects of moderate Nitrogen and Phosphorus addition on the species composition and dynamics of the tree seedlings community in tropical montane forests in southern Ecuador"
}

\author{
Dissertation zur Erlangung des Doktorgrades der \\ Mathematisch-Naturwissenschaftlichen Fakultäten der \\ Georg-August-Universität Göttingen
}

Vorgelegt von

Licenciada

Dayssy Maritza Cárate Tandalla

aus

Latacunga, Ecuador

Göttingen, October 2015 

Referent: Prof. Dr. Christoph Leuschner

Koreferent: Prof. Dr. Dirk Hölscher 

This dissertation is dedicated to the memory of Dr. Jaime Jaramillo (1944 - 2010), Supporting Curator at the QCA Herbarium - PUCE

"In gratitude for mentoring the first years of my scientific career"

Igualmente está dedicada a Nelly Tandalla y Alonsito Cárate

"Gracias por todo”, ¡Les quiero mucho! 



\section{TABLE OF CONTENTS}

SUMMARY viii

RESUMEN $\quad$ xi

$\begin{array}{ll}\text { Chapter } 1 & 1\end{array}$

GENERAL INTRODUCTION 1

1.1 Global changes effects on tropical forests 2

1.2 How seedlings respond to resources availability 3

1.3 Nutrient deposition effects on seedlings 5

1.4 General Objectives 5

$\begin{array}{lll}1.5 & \text { Outline of chapters } & 6\end{array}$

$\begin{array}{lr}\text { Chapter } 2 & 8\end{array}$

METHODOLOGY AND EXPERIMENTAL DESIGN 8

2.1 Study sites 9

$\begin{array}{lll}2.2 & \text { Experimental design } & 12\end{array}$

2.2.1 Seedling monitoring 13

2.2.2 Seedling Transplantation Experiment (STE) 16

2.2.3 Seedling Morphology 19

$\begin{array}{ll}\text { Chapter } 3 & 21\end{array}$

RESPONSES OF CONTINUED NITROGEN AND PHOSPHORUS ADDITION ON TREE REGENERATION IN A TROPICAL MONTANE FOREST IN SOUTHERN ECUADOR 21

$\begin{array}{lll}3.1 & \text { Summary } & 22\end{array}$

$\begin{array}{lll}3.2 & \text { Introduction } & 23\end{array}$

$\begin{array}{lll}3.3 & \text { Methods } & 24\end{array}$

3.3.1 Study site 24

3.3.2 The nutrient manipulation experiment 25

$\begin{array}{ll}\text { 3.3.3 Seedling monitoring } & 26\end{array}$ 
Contents

$\begin{array}{lll}\text { 3.3.4 Statistical analyses } & 27\end{array}$

3.4 Results 29

3.4.1 Effects of nutrient addition in seedlings density 29

3.4.2 Survival 30

3.4.3 Effects of nutrient addition on seedling recruitment 30

3.4.4 Effects of nutrient addition on seedling survival 30

3.4.5 Height differences among treatments 30

3.4.6 Height growth and leaf production 32

3.4.7 Herbivory 32

3.4.8 Species richness 34

3.5 Discussion 34

3.5.1 Seedling community dynamics 35

3.5.2 Height growth, leaf production and herbivory 36

3.5.3 Seedling species richness 37

3.6 Conclusions 37

3.7 Supplementary information 38

$\begin{array}{ll}\text { Chapter } 4 & 45\end{array}$

CONTRASTING SPECIES RESPONSES AMONG TROPICAL MONTANE FOREST TREE SEEDLINGS TO CONTINUED NITROGEN AND PHOSPHORUS ADDITION

$\begin{array}{lll}4.1 & \text { Summary } & 46\end{array}$

$\begin{array}{lll}4.2 & \text { Introduction } & 47\end{array}$

$\begin{array}{llr}4.3 & \text { Methods } & 50\end{array}$

4.3.1 Study site $\quad 50$

4.3.2 Experiment design 51

4.3.3 Mycorrhizal infection 53

4.3.4 Statistical analyses 53

$\begin{array}{lll}4.4 & \text { Results } & 54\end{array}$

4.4.1 Leaf morphology and herbivory $\quad 54$

4.4.2 Foliar nutrients 56

4.4.3 Biomass allocation $\quad 59$ 
4.4.4 Mycorrhizal colonization 61

4.5 Discussion 62

4.5.1 Leaf morphology, foliar nutrients and herbivory 63

4.5.2 Biomass partitioning and mycorrhizal colonization 65

$\begin{array}{lll}4.6 & \text { Supplementary information } & 67\end{array}$

$\begin{array}{ll}\text { Chapter } 5 & 72\end{array}$

PERFORMANCE OF SEEDLINGS OF A SHADE-TOLERANT TROPICAL TREE SPECIES AFTER MODERATE_ADDITION OF N AND P 72

$\begin{array}{lll}5.1 & \text { Summary } & 73\end{array}$

$\begin{array}{lll}5.2 & \text { Introduction } & 73\end{array}$

$\begin{array}{lll}5.3 & \text { Methods } & 77\end{array}$

$\begin{array}{lll}\text { 5.3.1 Study site } & 77\end{array}$

$\begin{array}{lll}\text { 5.3.2 Study species } & 77\end{array}$

5.3.3 Experimental design 78

$\begin{array}{lll}\text { 5.3.4 Leaf analyses } & 79\end{array}$

5.3.5 Nutrient analyses $\quad 80$

5.3.6 Data treatment and statistical analyses $\quad 80$

5.4 Results 81

5.4.1 Seedling growth and mortality 81

5.4.2 Leaf properties and herbivory 82

5.4.3 Biomass allocation 83

$\begin{array}{lll}5.5 & \text { Discussion } & 84\end{array}$

5.5.1 Seedling mortality and growth 84

5.5.2 Leaf properties and herbivory 87

5.5.3 Biomass allocation 89

$\begin{array}{llr}5.6 & \text { Conclusion } & 89\end{array}$

$\begin{array}{lll}5.7 & \text { Supplementary information } & 90\end{array}$

$\begin{array}{lr}\text { Chapter } 6 & 92\end{array}$

$\begin{array}{ll}\text { GENERAL DISCUSSION } & 92\end{array}$

$\begin{array}{lll}6.1 & \text { Introduction } & 93\end{array}$ 
Contents

6.2 Summary of main results and conclusions 93

$\begin{array}{lll}\text { 6.3 Effects of nutrient addition on tropical tree seedlings } & 100\end{array}$

6.3.1 Experimental approaches 101

6.3.2 Contrasting seedlings responses 103

$\begin{array}{lll}6.4 & \text { General conclusions } & 118\end{array}$

6.4.1 Final conclusions 118

6.4.2 Implications 121

6.5 Future work 122

$\begin{array}{ll}\text { REFERENCES } & 124\end{array}$

$\begin{array}{ll}\text { ACKNOWLEDGMENTS } & 145\end{array}$ 


\section{LIST OF TABLES}

Table 2.1 Summary of biotic and abiotic characteristics of the three study sites in Podocarpus National Park (PNP) and The San Francisco Reserve (SFR) in Southern Ecuador..

Table 3.1 Summary of mean seedling attributes of the six most common species in the seedling community

Table. S3.1 Species and morphospecies of woody plant seedlings registered from 2010-2013 in the NUMEX regeneration plots in the San Francisco Reserve.

Table. S3.2 Results of the models fit with nlme::: lme(). Details of the linear mixed effects models fitted with $\mathrm{R}$ package nlme.

Table S3.3 Results of the models fit with glmmADMB::: glmmadmb(). Details of the linear mixed effects models fitted with $\mathrm{R}$ package glmmADMB.

Table 4.1 Physiogeographic and stand structural characteristics of the three study sites.......51

Table 4.2 Summary of seedling responses to continued nutrient addition.. .54

Table. S4.1 Study site soil characteristics after continued nutrient addition. .68

Table. S4.2 Summary of the attributes of harvested seedlings of the six most common species in the three study sites

Table.S4.3 Summary of mean values of the attributes analyzed in the six most common species

Table 5.1 Properties of the initial seedling cohort before transplantation to NUMEX plots in June 2011.

Table 5.2 Summary of the properties of surviving Pouteria torta seedlings after one year...87

Table S5.1 Soil biochemical characteristics in top 5-cm of mineral soil of the Numex plots at 1000 m, measured in April 2012 after 4 years of treatment. .91

Table.S5.2 Structure of the used statistical models. 91

Table.6.1 Summary of 36 references published about fertilization experiments in tree seedlings in tropical forests worldwide from 1987-2014.. 


\section{LIST OF FIGURES}

Figure 2.1 Map of Ecuador showing the most important National Parks and Reserve Areas...

Figure 2.2 Vegetation structure of the three study stands.

Figure 2.3 NUMEX experimental factorial design for regeneration monitoring.

Figure 2.4 Diagram showing the dimensions of a vertical projection measured as seedling height.

Figure2.5 Output image produced by Gap Light Analyzer software

Figure2.6 Setup of seedling transplantation experiment in NUMEX experimental plots

Figure2.7 Summary of Seedling Transplantation Experiment 1 (STE1) setting up in Bombuscaro with Pouteria torta as target species

Figure 2.8 The most common species in the three altitudinal stands harvested for leaf morphological analyses

Figure.3.1 Effects of moderate nutrient addition on the whole seedling community and on the common and the rare species censussed during 3 years after 5 years of fertilization in San Francisco. Seedling density, seedling recruitment, and survival

Figure 3.2 Effects of moderate nutrient addition on the whole seedling community and on the common and the rare species censussed in San Francisco. Seedling height, relative height growth rate, relative increase in leaf number and extent of leaf herbivory

Figure 3.3 Effect of moderate nutrient addition on the species richness according to the seedling community

Figure 4.1 Morphological leaf attributes of the seedlings of six common tree species after N,

$\mathrm{P}$ or combined $\mathrm{N}$ and $\mathrm{P}$ addition

Figure 4.2 Leaf area loss due to herbivory in the seedlings of six common tree species after

$\mathrm{N}, \mathrm{P}$ or combined $\mathrm{N}$ and $\mathrm{P}$ addition .56

Figure 4.3 Foliar $\mathrm{N}$ and $\mathrm{P}$ concentrations in the seedlings of six common tree species after $\mathrm{N}$, $\mathrm{P}$ or combined $\mathrm{N}$ and $\mathrm{P}$ addition .58

Figure 4.4 Foliar N:P ratios in the seedlings of six common tree species after N, P or combined $\mathrm{N}$ and $\mathrm{P}$ addition.

Figure 4.5 Comparison of the proportions of biomass assignable to roots, shoots and leaves in the seedlings of six common tree species after $\mathrm{N}$ or/and $\mathrm{P}$ addition. 
Figure 4.6 Root:shoot ratio of the seedlings of six common tree species after N, P or combined $\mathrm{N}$ and $\mathrm{P}$ addition.....

Figure 4.7 Response in the percentage of AMF root colonization to N, P or combined N and $\mathrm{P}$ addition in seedlings of five common tree species

Figure.S4.1 Location of the three study sites in Podocarpus National Park and San Francisco

Reserve

Figure 5.1 Mean percentages of mortality in Pouteria torta seedlings observed during one year of exposure to moderate nutrient additions.

Figure 5.2 Relative diameter growth rates of Pouteria torta seedlings as a response to moderate nutrient addition

Figure 5.3 Leaf morphology, leaf area loss and nutrient ratios of Pouteria torta seedlings after one year of experimental exposure to nutrient addition. Specific leaf area (SLA), lost leaf area, foliar $\mathrm{N}: \mathrm{P}$ ratio and leaf $\mathrm{C}: \mathrm{N}$ ratio

Figure 5.4 Effects of nutrient addition on the biomass allocation of Pouteria torta seedlings. Changes in the root:shoot ratio, root:leaf ratio, leaf area ratio (LAR).

Figure S5.1 Nutrient manipulation experiment (NUMEX) and seedling study design. Above:

Schematic overview of the experimental design 90

Figure 6.1 Summary of the type of responses found in seedling growth in 36 studies from 1987-2015

Figure.6.2 Comparisons of growth rates for 37 seedling species responding to N, P and NP experiments from 36 publications for tropical forests 


\section{SUMMARY}

Anthropogenic activities have produced changes in natural ecosystems worldwide. In tropical regions in South America, industrialization of cities and forest clearance via burning are the main activities releasing pollutants into the atmosphere and inducing changes in nutrient deposition patterns and climate of primary forests.

Nitrogen $(\mathrm{N})$ and phosphorus $(\mathrm{P})$ are considered the main limiting nutrients of plant growth since their availability is vital for net primary productivity. Therefore, any change in $\mathrm{N}$ or $\mathrm{P}$ availability in soils would likely alter important mechanisms of forests dynamics such as growth and survival. Changes in soil $\mathrm{pH}$ (acidity), nutrient cycles and altered nutrient stocks affect $\mathrm{N}$ and $\mathrm{P}$ availability and affect various physiological processes of trees. Although low levels of nutrient deposition have been reported for montane forests in southern Ecuador (ca. $5 \mathrm{~kg} \mathrm{ha}^{-1}$ for $\mathrm{N}, 0.49 \mathrm{~kg} \mathrm{ha}^{-1}$ for P), even these levels are expected to lead to changes in forest structure and dynamics over the long term.

The responsiveness of forest to changes in resource availability varies with forest age and successional status, as well as life stage of the plant. Young plants (tree seedlings) should be more responsive to changes in nutrient availability than mature forest trees. Further, any demographic response is more likely to be visible in seedlings before mature trees because of the more rapid dynamics of seedlings. Therefore, I studied the regeneration dynamics of montane forest to understand which nutrient-related processes are involved in the growth and establishment of seedlings at both the individual and community levels.

The Ecuadorian NUtrient Manipulation EXperiment (NUMEX) has been designed to study the response of montane forest to moderate fertilization. The experiment has been set up over an elevation range across three main study sites (1000 m. a.s.l: Bombuscaro; $2000 \mathrm{~m}$. a.s.l: San Francisco; 3000 m. a.s.l: Cajanuma) within the Podocarpus National Park and San Francisco Reserve. The factorial experiment consists of four blocks containing four experimental plots (N, P, NP and control) in every study site (16 plots per elevation). Fertilization has been done since 2008, adding moderate quantities of fertilizer (50 kg ha $\mathrm{y}^{-1}$ of $\mathrm{N}$ and/or $10 \mathrm{~kg} \mathrm{ha}^{-1} \mathrm{y}^{-1}$ of $\mathrm{P}$ ). Three different approaches were used to assess the seedling community and common species responses to fertilization. First, the seedling community was monitored in natural forest at $2000 \mathrm{~m}$ over three consecutive years $(2011$ - 2013). In 192 monitoring subplots ( $1 \mathrm{~m}^{2}$ each) in San Francisco, all seedlings and saplings were mapped and 
tagged. Measurements of height, diameter, herbivory and leaf production were recorded for all individuals, and the number of recruited and dead seedlings was counted every year.

Second, allocation patterns and stoichiometry of seedlings of the six most common species were determined across the elevation gradient. Naturally occurring seedlings of the following species were harvested: Clarisia racemosa and Pouteria torta in Bombuscaro, Graffenrieda emarginata and Palicourea angustifolia in San Francisco and Grafferieda harlingii and Hedyosmum purpuracens in Cajanuma. Morphology (biomass allocation, herbivory and foliar areas such as SLA, LAR and LA) and foliar stoichiometry (nutrient contents and N:P ratios) were recorded and analyzed.

Third, a reciprocal transplantation experiment (STE) within the NUMEX experimental plots monitored seedlings of the most common species in Bombuscaro, (Pouteria torta), to assess specific responses in seedling performance over one year.

These three levels of analysis showed differential responses of the species community and common species to fertilization. Contrary to lowland forests, the community seedlings in this montane forest showed a moderate response. The density of seedling individuals decreased following nutrient addition, as a result of lower recruitment in treatments plots, but mortality was unaffected. Consequently, density-dependent mechanisms activated by additional $\mathrm{N}$ uptake did not show evidence of being a main driver to changes in species density.

The community of seedlings did not show significant growth in response to fertilization although seedlings were higher in the $\mathrm{N}$ treatment. However, $\mathrm{N}$ addition increased herbivory over all seedlings and plots, which could have masked other seedlings growth responses.

Common species seem to be well adapted to the relatively poor soils since these species were not favored by nutrient addition showing no change in growth or leaf traits. Over the long-term, common species might lose their dominance by being less competitive than faster growing species. However, it would need a longer period of monitoring under continued fertilization to produce visible shifts in community composition.

Species-specific responses are hard to determine in such species rich communities. Therefore, analyses of the six common species were conducted to complement the 
community-level study. Leaf morphology and foliar stoichiometry were assessed from harvested seedling from the experimental plots. Both $\mathrm{N}$ and $\mathrm{P}$ had effects on seedling traits, suggesting co-limitation of $\mathrm{N}$ and $\mathrm{P}$ in montane tree species in all elevations. However, foliar $\mathrm{N}: \mathrm{P}$ ratios and the more frequently response to $\mathrm{P}$ addition indicated this nutrient might be more limiting than $\mathrm{N}$ along the gradient.

Responsiveness of the studied species varied between the six species. Stronger foliar $\mathrm{P}$ concentration compared with $\mathrm{N}$ in all species but Pouteria torta suggested higher $\mathrm{P}$ consumption in montane forest species, similar to the responses of several other tropical plant species after $\mathrm{P}$ addition. Increased herbivory was only evident in the opposite responses of $G$. emarginata ( $\mathrm{N}$ and $\mathrm{N}+\mathrm{P}$ addition) and $P$. angustifolia (P addition) at $2000 \mathrm{~m}$ suggesting that plant selection by herbivores is driven by resource quality. Most of the species had higher belowground biomass in root fractions following fertilization, except for G. harlingii at 3000 $\mathrm{m}$, the only species that showed significant increase in aboveground biomass after nutrient addition.

Pouteria torta seedlings showed no significant changes in species performance after fertilization one year after establishment of the STE. Pouteria seems to be well-adapted to poor soils, since $\mathrm{N}$ and $\mathrm{P}$ addition did not alter foliar nutrient concentrations. Nevertheless, $\mathrm{N}$ and $\mathrm{N}+\mathrm{P}$ addition significantly increased mortality and diameter growth rates. $\mathrm{P}$ addition resulted in higher leaf area loss and shifted carbon allocation to root growth. These responses indicated consequences in the competitive strength in the understory and recruitment success of Pouteria torta. However, the ambiguous response in some attributes (growth and herbivory) not related with mortality made it difficult to predict the future abundance of this species in long term.

In conclusion, complementary studies demonstrated that specific nutrient limitation for $\mathrm{N}$ or $\mathrm{P}$ in montane species seem not to be a rule in rich species ecosystems although nutrient addition did alter some pattern of growth and survival. Thus, nutrient fertilization might affect various mechanisms and dynamics of plant communities, the balance of which will only play out over long time scales. 


\section{RESUMEN}

Las actividades antropogénicas han producido cambios en los ecosistemas alrededor del mundo. En las regiones tropicales de suramérica, la industrialización de las ciudades y el desmonte de los bosques por medio de quemas son las principales actividades que producen y expulsan contaminantes a la atmósfera e inducen cambios en los patrones de deposición de nutrientes y en el clima de los bosques primarios.

El nitrógeno $(\mathrm{N})$ y el fósforo $(\mathrm{P})$ son considerados los principales nutrientes que limitan crecimiento en las plantas ya que su disponibilidad es vital para la cadena de producción primaria de los bosques. Por esta razón, cualquier cambio en la disponibilidad de $\mathrm{N}$ o $\mathrm{P}$ en los suelos probablemente alteraría importantes mecanismos de la dinámica de los bosques tales como el crecimiento y la sobrevivencia. Cambios en el pH de los suelos (acidez), en los ciclos de nutrientes y en la cantidad de nutrientes afectan la disponibilidad de $\mathrm{N}$ y $\mathrm{P}$ y producen cambios en varios procesos fisiológicos de los árboles. Si bien bajas proporciones de nutrientes depositados han sido descritas para los bosque montanos del sur del Ecuador (ca. $5 \mathrm{~kg} \mathrm{ha}^{-1}$ for $\mathrm{N}, 0.49 \mathrm{~kg} \mathrm{ha}^{-1}$ for P), incluso a estos niveles se espera cambios en la estructura y en la dinámica de los bosques a largo plazo.

El grado de reacción de los bosques a los cambios en la disponibilidad de recursos es diferente con cada edad, estatus de sucesión natural, tanto como la etapa de vida de las plantas. Las plántulas de árboles (plantas jóvenes) deberían ser más sensibles a responder a cambios en la disponibilidad de nutrientes que los árboles del bosque maduro. Además, cualquier respuesta en la demografía de las plantas es probablemente más visible en las plántulas antes que en el bosque maduro debido a que las plántulas tienen una dinámica más rápida. Por esta razón, yo estudié la dinámica de la regeneración del bosque montano para entender qué procesos relacionados con los nutrientes están involucrados en el crecimiento y el establecimiento de las plántulas en ambos niveles, individual y de la comunidad de especies.

El experimento ecuatoriano de manipulación de nutrientes (NUMEX) ha sido diseñado para estudiar los cambios en el bosque montano como respuesta a la moderada fertilización. El experimento ha sido instalado en un gradiente altitudinal en tres principales sitios de estudio (1000 m.s.n.m.: Bombuscaro, 2000 m.s.n.m.: San Francisco, 3000 m.s.n.m.: Cajanuma) dentro del Parque Nacional Podocarpus y de la Reserva San Francisco. El 
Resumen

experimento factorial consiste en cuatro bloques que contienen las parcelas experimentales $(\mathrm{N}, \mathrm{P}, \mathrm{N}+\mathrm{P}$, control) en cada sitio de estudio (16 parcelas por elevación). La fertilización ha sido realizada desde el 2008 añadiendo moderada cantidad de fertilizantes (i.e., $50 \mathrm{~kg} \mathrm{ha}^{-1} \mathrm{y}^{-1}$ of $\mathrm{N}$ and/o $10 \mathrm{~kg} \mathrm{ha}^{-1} \mathrm{y}^{-1}$ of P).

Para el estudio de la regeneración de las plántulas de especies de árboles, se utilizaron tres diferentes metodologías para evaluar la comunidad de especies y las respuestas de las especies comunes a la fertilización.

La primera metodología consiste en el monitoreo de las comunidades de plántulas en el bosque a $2000 \mathrm{~m}$ en tres años consecutivos (2011 - 2013). En 192 sub-parcelas de monitoreo ( $1 \mathrm{~m}^{2}$ cada uno) en San Francisco, todas las plántulas y retoños fueron mapeados y etiquetados. Se estimaron y midieron altura, diámetro, herbivoría y producción de hojas en todos los individuos y se contó en número de nuevos reclutados en cada censo.

La segunda metodología determinó patrones de alocación de biomasa y la estequiometría de las plántulas de las seis especies comunes a lo largo del gradiente altitudinal. Las siguientes especies naturalmente abundantes fueron cosechadas: Clarisia racemosa y Pouteria torta en Bombuscaro, Graffenrieda emarginata y Palicourea angustifolia en San Francisco and Grafferieda harlingii y Hedyosmum purpuracens en Cajanuma. Morfología (alocación de biomasa, herbivoría y áreas foliares como: SLA, LAR, LA) y estequiometría de las hojas (contenidos de nutrientes y radios de $\mathrm{N}: \mathrm{P}$ ) fueron medidos y analizados.

La tercera metodología consiste en un experimento recíproco de transplante de plántulas (STE) dentro de las parcelas experimentales de NUMEX usando como especie focal, Pouteria torta, para evaluar respuestas específicas en el desenvolvimiento de las plántulas después de un año del experimento.

Los tres niveles de análisis mostraron respuestas diferentes a la fertilización de la comunidad de especies de plántulas y de las especies comunes. Contrariamente a los bosques bajos, la comunidad de especies en el bosque montano mostró una moderada respuesta a la fertilización. La densidad de los individuos decreció como consecuencia de la adición de nutrientes y como resultado del bajo reclutamiento en las parcelas experimentales, pero la mortalidad de las plántulas no fue afectada. Consecuentemente los mecanismos dependientes 
de la densidad activados por la absorción de $\mathrm{N}$ no mostraron evidencia de ser el principal eje impulsor de cambios en la densidad de las especies.

La comunidad de plántulas no mostró crecimiento por la adición de nutrientes a pesar de que las plántulas en los parcelas de $\mathrm{N}$ en general fueron siempre más altas con relación a las plántulas de las parcelas control. Sin embargo, la adición de N incrementó la herbivoría en todas las plántulas lo cual podría enmascarar las reales respuestas de crecimiento.

Las especies comunes aparentemente están bien adaptadas a los suelos relativamente pobres debido a que las especies no fueron favorecidas por los cambios en los nutrientes del suelo, mostrando pocos o ningún cambio en crecimiento o en la morfología de las hojas. En un largo período de tiempo, las especies comunes perderían su dominancia por ser menos competitivas que las especies de crecimiento rápido. Sin embargo, se necesitaría un período de tiempo de monitoreo largo bajo continua fertilización para producir cambios visibles en la composición de las comunidad.

Las respuestas específicas son difíciles de determinar en comunidades ricas en especies. Por ello, se llevó a cabo el análisis de las seis especies más comunes en un estudio complementario al monitoreo de las comunidad de especies de plántulas. Se evaluó la morfología de las hojas y plántulas además de la estequiometría de las hojas en plántulas cosechas en las parcelas experimentales. Ambos nutrientes (N y P), provocaron efectos en los atributos estudiados sugiriendo una estrecha co-limitación de $\mathrm{N}$ y $\mathrm{P}$ en las especies de árboles en todos los niveles altitudinales. Sin embargo, los radios de N:P y la frecuente respuesta de las especies a la adición del $\mathrm{P}$ indicaron que este nutriente podría ser más limitante que el $\mathrm{N}$ a lo largo del gradiente.

El grado de reacción de las especies estudiadas varía entre las seis especies. Mayor concentración de $\mathrm{P}$ en las hojas en relación al $\mathrm{N}$ fue evidente en todas las especies menos en Pouteria torta sugiriendo un alto consumo de $\mathrm{P}$ en las especies del bosque montano, similar a las respuestas encontradas en otras especies de plantas tropicales después de fertilización con P. El incremento de la herbivoría fue evidente solamente en dos especies aunque las respuestas fueron opuestas en G. emarginata $(\mathrm{N}$ y N+P) y en P.angustifolia (P) a $2000 \mathrm{~m}$ mostrando que la selección de las plantas por herbivoría es impulsada por la calidad de los recursos. Muchas de las especies estudiadas mostraron alta maximización de la adquisición de recursos debajo del suelo por la acumulación de biomasa en las raíces, con excepción de 
Resumen

G. harlingii a 3000 m., la única especies que mostró alocación significativa de biomasa sobre el suelo como respuesta de la adición de nutrientes.

Las plántulas de Pouteria torta mostraron un cambio no significativo en el desenvolvimiento de las especies después de un año de fertilización en STE. Pouteria torta está bien adaptada a los suelos pobres, ya que la adición de $\mathrm{N}$ y $\mathrm{P}$ no alteró las concentraciones foliares de nutrientes. Sin embargo, la adición de N y N+P significantemente incrementó la mortalidad y el crecimiento de diámetro. La adición de $\mathrm{P}$ resultó en un incremento de la perdida de área foliar por herbivoría y desplazó la alocación de carbono al crecimiento de las raíces. Estas respuestas indicaron consecuencias en la fuerza de competencia en el sotobosque y el éxito de reclutamiento de Pouteria. Sin embargo, debido a que las respuestas son ambigüas de algunos atributos (crecimiento y herbivoría) y no están relacionadas con mortalidad es difícil establecer predicciones acerca de la futura abundancia de esta especie a largo plazo.

En conclusión, estudios complementarios demostraron que la limitación de un único nutriente en las especies de los bosques montanos no ocurre en un ecosistema rico en especies, a pesar de que los nutrientes están fuertemente correlacionados en mecanismos para la supervivencia y crecimiento. Por consiguiente, la fertilización con nutrientes afectaría varios mecanismos y dinámicas en las comunidades de plantas, el resultado de los cuales se desarrollaría en una escala de largo tiempo. 


\section{Chapter \\ 1}

GENERAL INTRODUCTION 


\subsection{Global changes effects on tropical forests}

Population growth and growing consumption of resources affect tropical ecosystems in a variety of ways (Luque et al., 2013). Aerial pollution is produced by many activities such as biomass burning, agricultural expansion and industrialization of cities. Consequently, ecosystems worldwide are sensitive to additional doses of pollutants deposited remotely on soils. Major effects caused by such deposition would produce noticeable reduction in biodiversity of ecosystems. As such, deposition represents a significant danger to ecosystems services and human societies using those resources.

Nutrient availability is a strong driver of ecosystems processes. Variability in ecosystem functioning depends directly on soil nutrient contents, which enhance a variety of patterns and mechanisms for survival. Those mechanisms are associated with changes in plant growth rates, nutrient cycles, net primary productivity and biodiversity (Hyvönen et al., 2006; Galloway, 2008; Elser et al., 2007; Bellard et al., 2012). So far, several meta-analyses concerning net primary productivity worldwide indicated that nitrogen $(\mathrm{N})$ is the most limiting nutrient in global terrestrial ecosystems although phosphorus (P) limitation can be equally strong if not stronger in some regions (Elser et al., 2007; Le Bauer \& Tresender, 2008; Gruber \& Galloway, 2008; Xia \& Wan, 2008).

Several experiments of nutrient fertilization have shown strongly positive synergetic responses among the $\mathrm{N}$ and $\mathrm{P}$ (e.g., Ceccon, 2004; Le Bauer \& Tresender, 2008; Davidson et al., 2004). Ecosystems responses include enhanced soil $\mathrm{C}$ sequestration (after $\mathrm{N}$ and $\mathrm{P}$ addition: Li et al., 2006), decrease of belowground $\mathrm{C}$ cycling (after $\mathrm{N}$ and $\mathrm{P}$ addition: in Giardina et al., 2004), large soil $\mathrm{CO}_{2}$ losses (after P addition: Cleveland \& Townsend, 2006) or increases in soil carbon stocks (after $\mathrm{N}$ and P addition: Gamboa et al., 2009) suggesting complex interactions between nutrient availability and $\mathrm{C}$ turnover, and highlighting our incomplete understanding about the responses of the $\mathrm{C}$ cycle to future changes in nutrient availability (Cleveland \& Towsend, 2006; Cleveland et al., 2006; Wright, 2005). Nutrient deposition might also increase acidification and subsequently negatively affect forest growth where forests are not $\mathrm{N}$-limited (Lewis et al., 2004).

Few studies have quantified tropical forest growth in terms of stem diameter growth in mature trees. The most important experiments have been done in lowland tropical forest showing responses after $\mathrm{N}$ addition (Andersen et al., 2010; Bungard et al., 1994; Cai et al., 
2008; Mo, Li \& Gundersen, 2008; Schreeg et al., 2014; Thompson et al., 1995). In the last decades, experiments in Jamaican montane forests (Tanner et al., 1990) and Hawaiian Metrosideros forests (Vitousek \& Farrington, 1997) have also shown responses to N. Others experiments (e.g., Cavelier et al., 2000) have shown growth responses after combined N+P addition possibly suggesting a nutrient co-limitation. In the last years, new experimental results in montane forests also showed responses which support co-limitation in nutrient interactions (Wullaert et al., 2010; Wright et al., 2011; Homeier et al., 2013, Fisher et al., 2013; Camenzind, et al., 2014). However, these results are still inconclusive and partly contradictory.

Above a certain level of nutrient deposition, tropical ecosystems might move towards saturation with resulting bio-chemical responses (e.g., increased nitrate leaching and soil acidification) as it is known for temperate forests. The effects of elevated $\mathrm{N}$ inputs into temperate ecosystems has been investigated by a number of coordinated studies (Aber et al., 2008; Högberg et al., 2006; Magil et al., 2004; Mo et al., 2008) and showed that species which are adapted to poor soils and have lower biological $\mathrm{N}$ demand are affected more strongly by the increase of soil $\mathrm{N}$ availability (Pardo et al., 2007).

By investigating species performance in different stages of development under nutrient addition (Alvarez-Claré et al., 20013), it might be possible to quantify responses to additional nutrient availability in the long term and elucidate how nutrients might alter species composition and therefore diversity, community structure and ecosystem functioning under global change scenarios.

\subsection{How seedlings respond to resources availability}

Processes affecting early stages (e.g., tree seedlings and saplings) act as a strong filter for controlling pattern of tree recruitment and thereby influence future forest composition (Metz et al., 2008; Swaine, 1996; Whitmore, 1996). Tree seedlings in the understory depend on resources such as light, water and essential mineral nutrients to survive and grow in a highly competitive environment.

Water is important for plants due to the relationship between soil drainage with physical properties. In early stages, water affects seedling survival and establishment through 
damages caused by desiccation and reduction of seed germination (Turner, 2002). Then, water might also control initial densities of germinated young plants (Kitajima \& Fenner, 2000; Turner, 2002).

Light was considered to be the most important factor determining the success of tree seedling establishment in all forests (Swaine, 1996; Whitmore, 1996). Seedlings have been classified as light demanding and shade tolerant according to main characteristics shown in the adaptability to light in the understory. Both types are distinguished by the different tradeoffs they perform to compensate for light limitation (Garwood, 1996; Kitajima, 1996; Kitajima \& Fenner, 2000; Turner, 2002; Metz et al., 2008). For decades, mechanisms of coexistence between seedlings types have captured the attention of scientists. As a result, a variety of compensatory functional strategies has been identified for seedlings survival and growth (i.e., store nutrients in cotyledons, carbon allocation after germination, leaf morphological traits, and germination synchrony) (Ericsson \& Ehrlén, 2008; Kitajima \& Myers, 2008; Kollman, 2008; Queenborough, 2007; Garwood, 2009).

Coexistence in early stages additionally depends on a number of biotic factors often causing stresses by conspecific and heterospecific competition, physical damage, tramping by no-herbivores and litter burial (Kitajima \& Fenner, 2000). But importantly, physiological adaptations to nutrient availability have been observed to play the most important role for seedling performance in the understory.

Numerous studies carried out in the last decades focussed on separating the effects of above-and below-ground seedling competition by using reciprocal transplantation experiments (Baltzer et al., 2005; Lewis \& Tanner, 2000; Dent \& Burslem, 2009), trenching (Barberis \& Tanner, 2005; Coomes \& Grubb, 1998) or experimental nutrient addition (Baraloto et al., 2006; Mo et. al., 2008; Yawitt \& Wright, 2008; Santiago et al., 2006; Andersen et al., 2014). The results showed that below-ground competition for nutrients has to be considered as an important factor influencing seedling growth, especially on less fertile soils (Coomes \& Grubb, 1998 and 2000; Kueffer et al., 2007; Lewis \& Tanner, 2000). In fact, soil nutrient availability mediates different seedling performance (recruitment and survival), influencing the further spatial distribution of tropical forest tree species and this is likely to play an important role in structuring future forests communities (Beckage \& Clark, 2003; Palmioto et al., 2004; Bellingham \& Richardson, 2006). 


\subsection{Nutrient deposition effects on seedlings}

Fertilization experiments with tree seedlings have demonstrated that the growth response of young plants to limited nutrient availability can be expressed in terms of height or diameter increment (Bungard et al., 2000; Yavitt \& Wright, 2008), productivity of foliar structures (Burslem et al., 1994; Gunatilleke et al., 1997), reallocation of biomass (Cai et al., 2008; Palmiotto et al., 2004) and/or changes in photosynthetic efficiency in leaves (Pasquini \& Santiago, 2012). Additionally, high concentration of $\mathrm{N}$ in leaves has been found to increase the palatability of foliar structures (Andersen et al., 2010; Campo \& Dirzo, 2003).

Intensity of seedling responses is associated with resource requirement to physiological functioning of individuals and species (Boege \& Marquis, 2005). Thus, adequate availability of resources would benefit young plants for establishment and growth.

A variety of experimental approaches have been used in tropical forests to investigate the differential responses of seedlings to different levels of nutrient availability. The most notable compilation of those studies is a meta-analysis published by Lawrence (2003) including fifteen studies across three major tropical forests regions (America, Africa, Asia/Australia). For the present work, a short systematic review of fertilization studies is presented to evaluate seedlings responses in tropical forests with the aim to contrast different approaches with the findings in this dissertation. Since 2003, approximately 24 additional experiments have been carried out with tropical tree seedlings using three main methodologies to evaluate seedling responses. Those experimental designs and their results will be briefly classified, summarized and discussed in the last chapter.

\subsection{General Objectives}

As part of the Ecuadorian Nutrient Manipulation Experiment (NUMEX), this research is focused on the regeneration of tropical montane forest trees under experimental nutrient addition.

The main aim of this research was to study seedling dynamic responses from community to specific levels to understand how shifts in seedling composition might be affected by moderate changes in soil nutrient availability. To assess the responses of the 
Chapter 1

young tropical montane forests to moderate nutrient addition, the following main hypotheses have been proposed:

1. Seedling dynamics (i.e., growth, mortality and recruitment) is fastened, and density of individuals is changing as a response to long term nutrient addition to Andean montane forests.

2. Continued nutrient addition might lead to compositional changes in the tree seedling assemblages by modifying species-specific responses to increased nutrient availability.

3. Seedlings are more responsive to nutrient additions than mature montane forest trees, and changes in seedling traits (i.e., growth rates, leaf morphology and biomass allocation) might vary in the presence of additional nutrient input.

\subsection{Outline of chapters}

The present dissertation is a compilation of three different approaches to investigate seedling dynamics in responses to moderate addition of $\mathrm{N}$ and $\mathrm{P}$.

At the start, a methodological description of the NUMEX experimental design is given in Chapter 2 due to the fact that this study belongs to a bigger multidisciplinary approach. Details of the specific study area and the specific methodology of seedling experiments and monitoring are also described in this chapter in order to include relevant information not detailed in the further chapters.

Community responses are important to evaluate changes in species richness and composition. The first approach addressed in Chapter $\mathbf{3}$ focuses on the community responses to $\mathrm{N}$ and $\mathrm{P}$ addition, separating and comparing performance of common and rare species.

Species specific responses may be different depending on resource availability. In Chapter 4, a comparison between the most common species in the three study sites evaluates morphological traits changes as a result of nutrient addition. Differences in leaf traits, nutrient contents and biomass allocations have been analyzed in six common species: Clarisia racemosa (Moraceae) and Pouteria torta (Sapotaceae) at $1000 \mathrm{~m}$, Graffenrieda emarginata 
(Melastomataceae) and Palicourea angustifolia (Rubiaceae) at $2000 \mathrm{~m}$, Graffenrieda harlingii (Melastomataceae) and Hedyosmun purpuracens (Chloranthaceae) at $3000 \mathrm{~m}$.

Individual species responses are important to understand strategies of coexistence driven by limiting resources. In Chapter 5, the results of a seedling transplantation experiment conducted in premontane forest (at $1000 \mathrm{~m}$ ) is presented. Seedlings of the most common species in this study site, Pouteria torta (Sapotaceae), were used to assess effects of nutrient amendments on seedling performance during one year of monitoring growth performance and leaf traits.

Finally, in Chapter 6, a general discussion summarizes the results of community and specific experimental approaches and presents a general conclusion. A short systematic review contrasts different results about responses of tropical tree seedlings to nutrient addition in different experimental approaches. A summary of all experiments conducted so far, including the contributions of this study, demonstrates there are still many open questions about montane forest seedlings dynamics. At the end, a perspective of complementary studies being conducted in tropical montane forest will be addressed. 


\section{Chapter \\ 2}

METHODOLOGY AND EXPERIMENTAL DESIGN 


\subsection{Study sites}

The Ecuadorian NUtrient Manipulation Experiment (NUMEX) was set up in 2007 in the tropical montane forests (TMF) of southern Ecuador. The study sites were established within the Podocarpus National Park (PNP) and in the San Francisco Reserve (RSF) which is located at the northern boundary of the park. Three study sites were established along an altitudinal gradient of montane forests as follows:

- the lowermost site, “Bombuscaro", is located at ca.1000 m. in the eastern part of the cordillera belonging to the PNP near to the city Zamora;

- the mid-elevation site, "San Francisco", located between the cities of Loja and Zamora at ca. $2000 \mathrm{~m}$. in the valley of the Río San Francisco; and,

- the uppermost site, "Cajanuma", at ca. $3000 \mathrm{~m}$. in the western part of the PNP located between the city of Loja and the town of Vilcabamba, (Figure 2.1).

The three study sites comprise evergreen old-growth montane forest showing remarkable differences between them concerning forest structure, climate and soil characteristics (Figure 2.2, Table 2.1).

Natural vegetation in Bombuscaro corresponds to premontane forest characterized by an open understory occupied by tree species reaching heights between 20-25 up to $40 \mathrm{~m}$ (Homeier et al., 2013), plant families like Sapotaceae, Moraceae are common in this stand (Homeier et al., 2013). Species composition is influenced by common taxa distributed in lowland tropical forests (e.g., Sapotaceae, Moraceae and Lauraceae) as well as those distributed in Andean forests (e.g., Asteraceae, Araliaceae and Melastomataceae).

The lower montane forest, San Francisco is characterized by the increment in abundance of epiphytic lifeforms growing on tree trunks and denser shrub layer in the understory. The canopy is lower than in Bombuscaro reaching approximately 10-14 m height. Common plant families in this stand are Melastomataceae, Euphorbiaceae and Lauraceae (Homeier et al., 2013). 


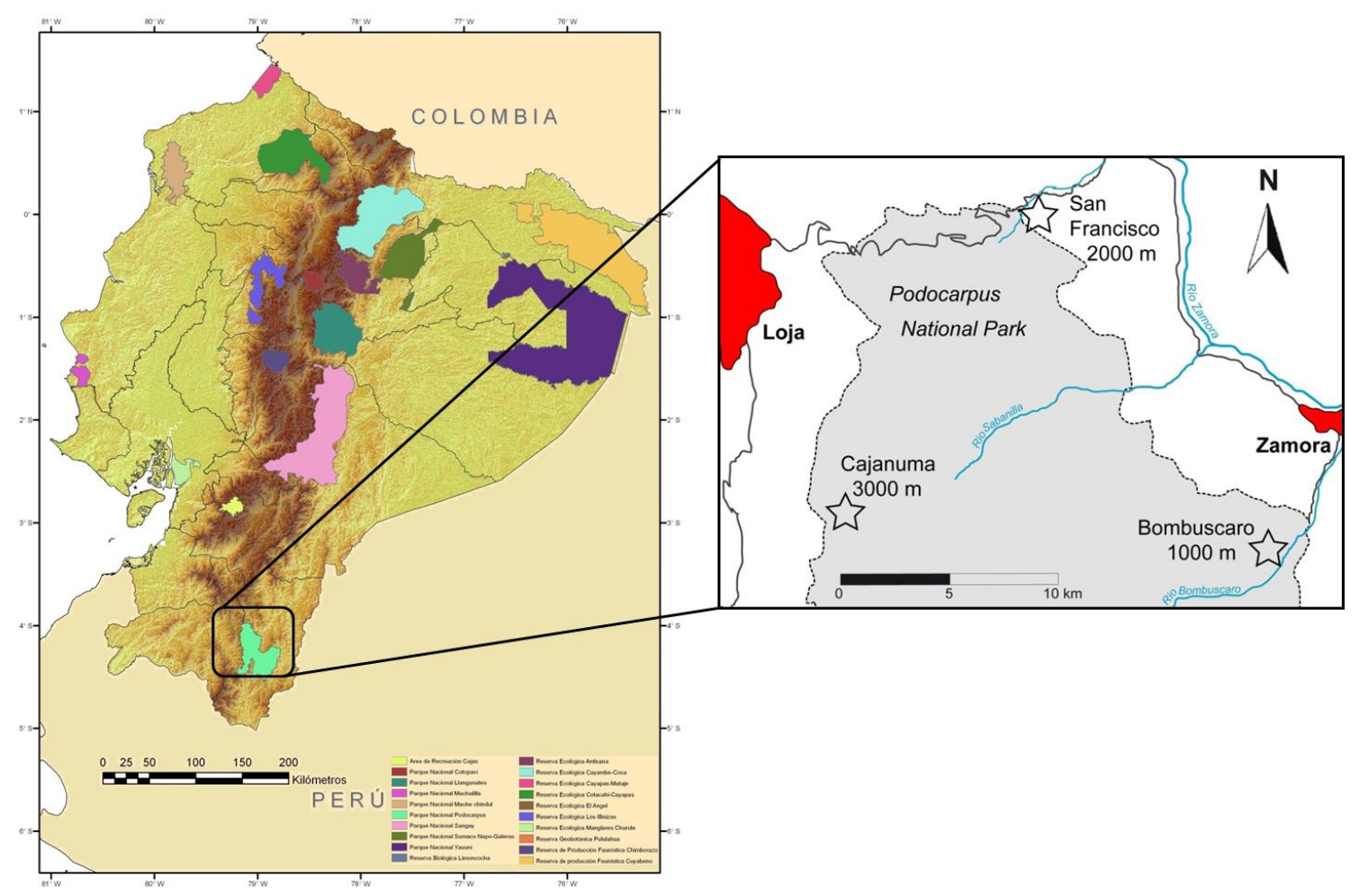

Figure 2.1 Map of Ecuador showing the most important National Parks and Reserve Areas (Left). Podocarpus National Park (PNP) area is highlighted in black and a close up of the region (Right) shows the approximate locations of the three stands: Bombuscaro (1000 m.a.s.1.), San Francisco (2000 m.a.s.1.) and Cajanuma (3000 m.a.s.l.). Left picture is a courtesy of B.S. Janeth Santiana. Right picture is adapted from Homeier et al., 2012.

The upper montane forest, Cajanuma harbors dense vegetation with trees growing mixed with numerous shrubs species. Canopy reaches between 6-8 $\mathrm{m}$ height with common plant families such as: Cunnoniaceae, Chlorantaceae, Clusiaceae and Melastomataceae (Homeier et al., 2012). Additional characteristics of forest structure are summarized in the information of Table 2.1.

Climate conditions are also remarkably different in the three sites. Bombuscaro is the warmest site with an average temperature of $20{ }^{\circ} \mathrm{C}$. San Francisco is moderately warm with temperature ca. $16{ }^{\circ} \mathrm{C}$ and Cajanuma average temperature reach to $10{ }^{\circ} \mathrm{C}$ (Richter et al., 2013). Precipitation patterns are diverse throughout the year, with the biggest episodes of precipitation are registered from February to June. However, those patterns were not considered strong enough to be defined as a rainy season in previous climate studies (Emck, 2007). 
Table 2.1 Summary of biotic and abiotic characteristics of the three study sites in Podocarpus National Park (PNP) and The San Francisco Reserve (SFR) in Southern Ecuador. Forest structure values represent mean values.

\begin{tabular}{|c|c|c|c|}
\hline & Bombuscaro & San Francisco & Cajanuma \\
\hline \multicolumn{4}{|l|}{ Location } \\
\hline Altitudinal range (m.a.s.l.) & $990-1100$ & $1950-2100$ & $2900-3050$ \\
\hline Coordinates & $4^{\circ} 7^{\prime} \mathrm{S}, 78^{\circ} 58^{\prime} \mathrm{W}$ & $3^{\circ} 58^{\prime} \mathrm{S}, 79^{\circ} 11^{\prime} \mathrm{W}$ & $4^{\circ} 7^{\prime} \mathrm{S}, 79^{\circ} 11^{\prime} \mathrm{W}$ \\
\hline Temperature $\left({ }^{\circ} \mathrm{C}\right) £$ & 19.4 & 15.7 & 9.4 \\
\hline Mean precipitation $(\mathrm{mm}) \mathfrak{f}$ & 2200 & 1900 & 4500 \\
\hline \multicolumn{4}{|l|}{ Forest Structure } \\
\hline Stand height (m) & $20-25$ & $10-14$ & $6-8$ \\
\hline Tree density $\left(\right.$ trees $\left.\mathrm{ha}^{-1}\right)$ & 748 & 1143 & 1305 \\
\hline Basal area $\left(\mathrm{m}^{2} \mathrm{ha}^{-1}\right)$ & 33.4 & 22.8 & 25.5 \\
\hline Vegetation Type $\gamma$ & $\begin{array}{c}\text { Evergreen } \\
\text { premontane forest }\end{array}$ & $\begin{array}{c}\text { Evergreen } \\
\text { lower montane forest }\end{array}$ & $\begin{array}{c}\text { Evergreen } \\
\text { upper montane forest }\end{array}$ \\
\hline Common families $\gamma$ & $\begin{array}{l}\text { Moraceae, } \\
\text { Sapotaceae }\end{array}$ & $\begin{array}{c}\text { Melastomataceae, } \\
\text { Euphorbiaceae, } \\
\text { Lauraceae }\end{array}$ & $\begin{array}{c}\text { Cunnoniaceae, } \\
\text { Clusiaceae, } \\
\text { Melastomataceae }\end{array}$ \\
\hline Common species $\gamma$ & $\begin{array}{l}\text { Clarisia racemosa, } \\
\text { Pouteria torta, } \\
\text { Hedyosmum sprucei, }\end{array}$ & $\begin{array}{c}\text { Myrcia sp. nov., } \\
\text { Graffenrieda } \\
\text { emarginata, } \\
\text { Palicourea } \\
\text { angustifolia, Miconia } \\
\text { punctata }\end{array}$ & $\begin{array}{l}\text { Hedyosmum } \\
\text { purpuracens, } \\
\text { Graffenrieda harlingii, } \\
\text { Weinmmania } \\
\text { pubescens, } \\
\quad \text { Clusia eliptica }\end{array}$ \\
\hline Soil type ${ }^{\delta}$ & Dystric Cambisol & Stagnic Cambisol & Stagnic Histosol \\
\hline Organic layer ${ }^{\delta}$ & $<1 \mathrm{~cm}$ & $10-30 \mathrm{~cm}$ & $10-40 \mathrm{~cm}$ \\
\hline \multicolumn{4}{|l|}{ Soil features $(0-5 \mathrm{~cm}) \dagger$} \\
\hline Mineral soil ${ }^{\delta}$ & Mineral soil & Organic layer & Organic layer \\
\hline $\mathrm{pH}(\mathrm{H} 2 \mathrm{O}) \dagger$ & $4.3 \pm 0.2$ & $4.0 \pm 0.1$ & $3.7 \pm 0.2$ \\
\hline Total $\mathrm{C}\left(\mathrm{kg} \mathrm{C} \mathrm{m}^{-2}\right) \dagger$ & $2.5 \pm 0.7$ & $4.4 \pm 0.1$ & $2.6 \pm 0.1$ \\
\hline Total $\mathrm{N}\left(\mathrm{g} \mathrm{N} \mathrm{m}^{-2}\right) \dagger$ & $168 \pm 35$ & $167 \pm 12$ & $75 \pm 4$ \\
\hline $\mathrm{C} / \mathrm{N}$ ratio $\dagger$ & $14 \pm 1$ & $26 \pm 2$ & $35 \pm 1$ \\
\hline Total $\mathrm{P}\left(\mathrm{g} \mathrm{P} \mathrm{m}^{-2}\right) \dagger$ & $29 \pm 7$ & $6 \pm 1$ & $3 \pm 1$ \\
\hline
\end{tabular}


Chapter 2
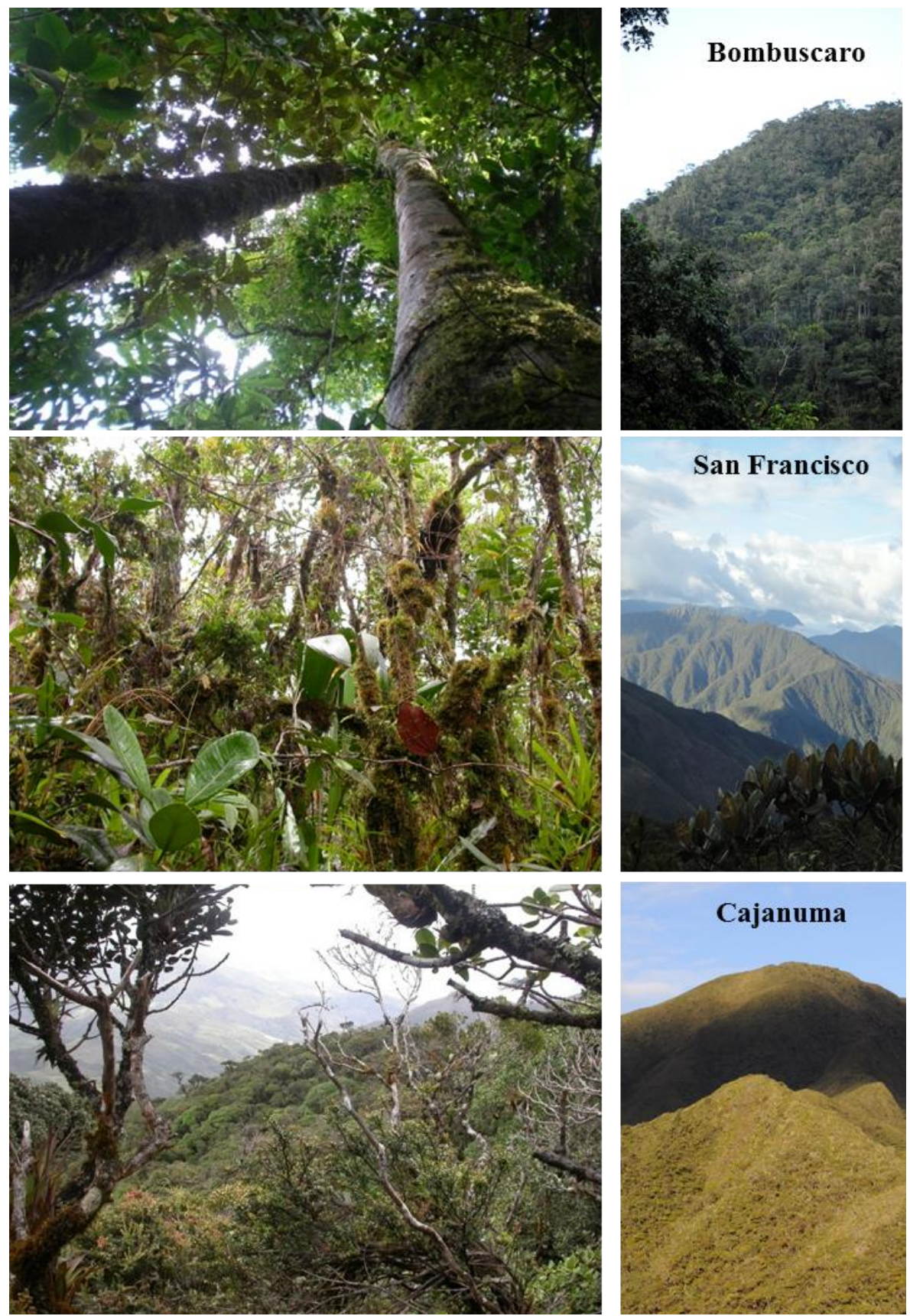

Figure 2.2 Vegetation structure of the three study stands. (Left pictures) Vegetation view from understory. (Right pictures) External view of the vegetation in Bombuscaro, San Francisco and Cajanuma. Photos: D.Cárate-Tandalla, J. Homeier.

\subsection{Experimental design}

A full factorial nutrient experiment was established in old-growth montane forest stands in southern Ecuador. Bombuscaro (1000 m), San Francisco (2000 m) and Cajanuma 
(3000 m) study sites are located in protected areas (i.e., Podocarpus National Park and San Francisco Reserve).

Annual bulk $\mathrm{N}$ deposition by precipitation ranged from $9.5-10 \mathrm{~kg} \mathrm{~N} \mathrm{ha}^{-1}$ during the period of 1998 - 2003 (Boy et al., 2008). However, recent data from monitoring bulk and dry deposition during 1998 - 2010 (Wilcke et al., unpublished data) indicated annual deposition of $14-45 \mathrm{~kg} \mathrm{~N} \mathrm{ha}^{-1}$ and $0.4-4.9 \mathrm{~kg} \mathrm{P} \mathrm{ha}^{-1}$ (Homeier et al., 2013).

In each elevation stand, four blocks, with 16 plots (Figure 2.3, Left-up), of $400 \mathrm{~m}^{2}$ each $(20 \times 20 \mathrm{~m})$ were set up inside the primary forests with no visible signs of human or natural disturbance. Each block accommodated four experimental plots $(+\mathrm{N},+\mathrm{P}, \mathrm{N}+\mathrm{P}$ and control) separated from each other by at least $10 \mathrm{~m}$.

Additionally, 6 sub-plots $(2 \times 2 \mathrm{~m})$ were randomly installed inside every experimental placed along two perpendicular transects (Figure 2.3., Right-up). Complementary studies for monitoring litter production, water drainage, below-ground biomass and soil gas emissions in response of extra nutrient addition were conducted within every $4 \mathrm{~m}^{2}$.

Fertilization in the experimental plots started in February 2008, nutrients were addedtwice per year (i.e., February/March and August/September). Fertilizer was added by hand in moderate quantities: nitrogen ( $\mathrm{N}: 50 \mathrm{~kg} \mathrm{ha}^{-1} \mathrm{yr}^{-1}$, as urea), phosphorus ( $\mathrm{P}: 10 \mathrm{~kg} \mathrm{ha}{ }^{-}$ ${ }^{1} \mathrm{yr}^{-1}$, as $\mathrm{NaH}_{2} \mathrm{PO}_{4} 2 \mathrm{H}_{2} \mathrm{O}$ with analytical grade quality) and the combination of $\mathrm{N}+\mathrm{P}$ (Homeier et al., 2013).

\subsubsection{Seedling monitoring}

Twelve small permanent regeneration plots $\left(1 \mathrm{~m}^{2}\right)$ were placed randomly within each experimental plot resulting in a total of 192 regeneration plots, (48 per treatment). Regeneration monitoring plots were set up in pairs following the arrangement of the perpendicular transect installed in every NUMEX experimental plot (Figure 2.3, upper right). Within regeneration plots, all woody plant seedlings and saplings were marked, labeled and mapped (Figure 2.3, lower right). All stems of a height $\geq 5 \mathrm{~cm}$ and a basal diameter $\leq 1 \mathrm{~cm}$ were tagged (Figure 2.3, lower left). 

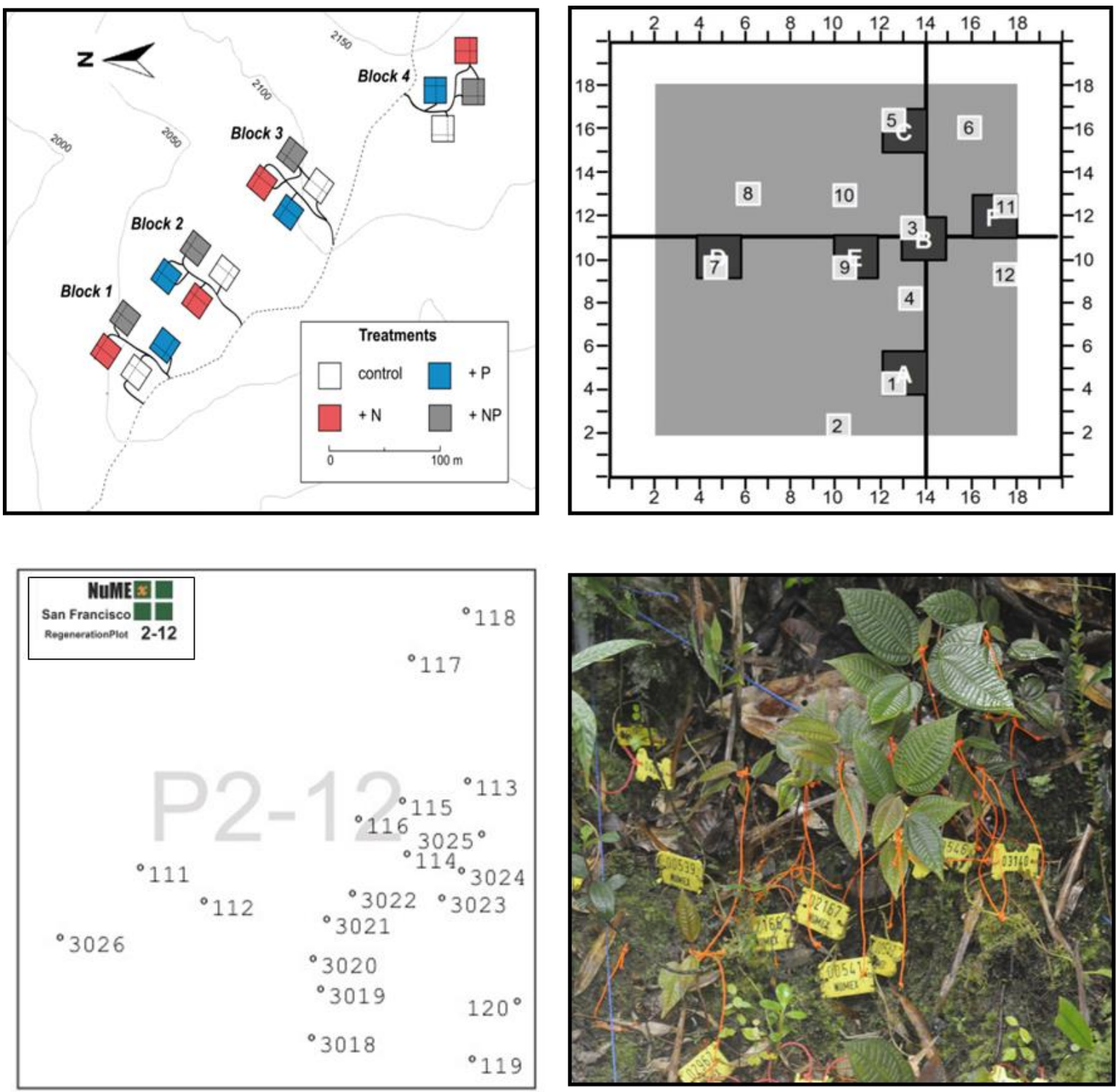

Figure 2.3 NUMEX experimental factorial design for regeneration monitoring. (Lower left) Blocks arrangement and experimental plots. (Upper right) Diagram of the distribution of 6 subplots $(2 \times 2 \mathrm{~m})$ identified with letters following the guide lines in every experimental plot, and regeneration monitoring plots $\left(1 \mathrm{~m}^{2}\right)$ in white identified with numbers (Lower left). One regeneration plot map indicating the exact location of every seedling tagged (Lower right) .Inside of one of the 192 seedling monitoring plots in San Francisco, seedling are tagged and numbered. Photo: D. Cárate-Tandalla

All study sites were censussed three times: 1) April-May 2011; 2) April-May 2012 and 3) May-June 2013. Every year, newly recruited individual were tagged and dead individuals were registered. In surviving seedlings, the following parameters were recorded: 
stem height (vertical projection from the forest floor to the apical tip), stem diameter (at stem base), number of leaves or leaflets, and an estimated percentage of leaf area loss by folivory (Figure 2.4).

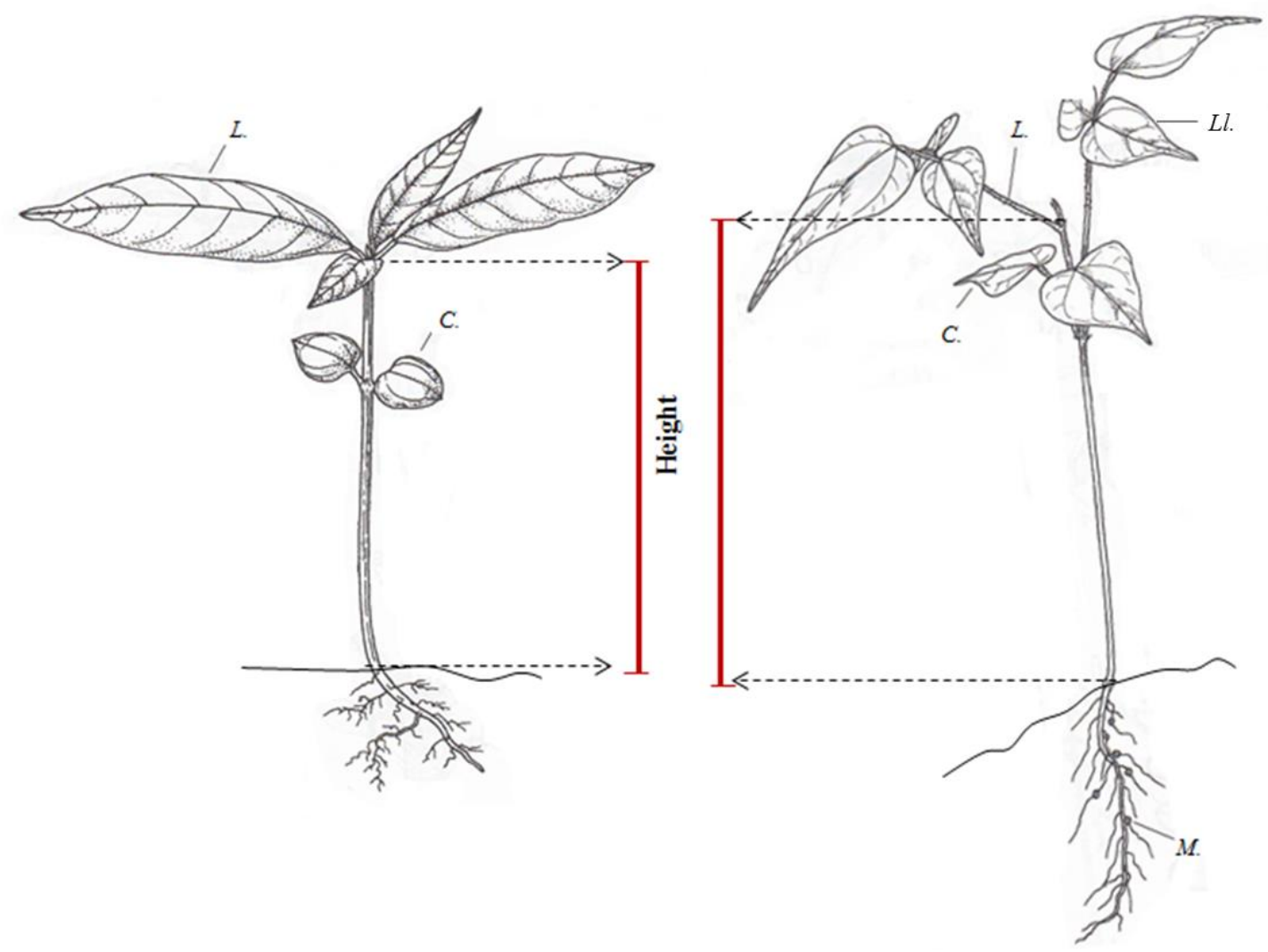

Figure 2.4 Diagram showing the dimensions of a vertical projection measured as seedling height. Apical tip depends of the leaf type of seedlings. Left: seedling of Palicourea sp. (Rubiaceae) "simple leaf" is growing on flat ground. Right: seedling of Inga sp. (Mimosaceae) "compound leaf" is growing on an irregular ground. Letters indicate important seedling structures and associations: (L.) leaves, (C) Cotyledons, (Ll) Leaflets, and (M) Mychorriza. Illustration was modified from Garwood (2009).

Light availability was quantified for every regeneration monitoring plot by hemispherical photos $1 \mathrm{~m}$ above the center of every plot using a Nikon D5000 camera with a 8 mmfish-eye lens. Images were taken in the first census (July 2011) under cloud conditions. Photos were analyzed with Gap Light Analyzer software (Frazer et al., 1999) to calculate canopy openness, diffuse light transmission and direct light transmission (Figure 2.5). 
Chapter 2

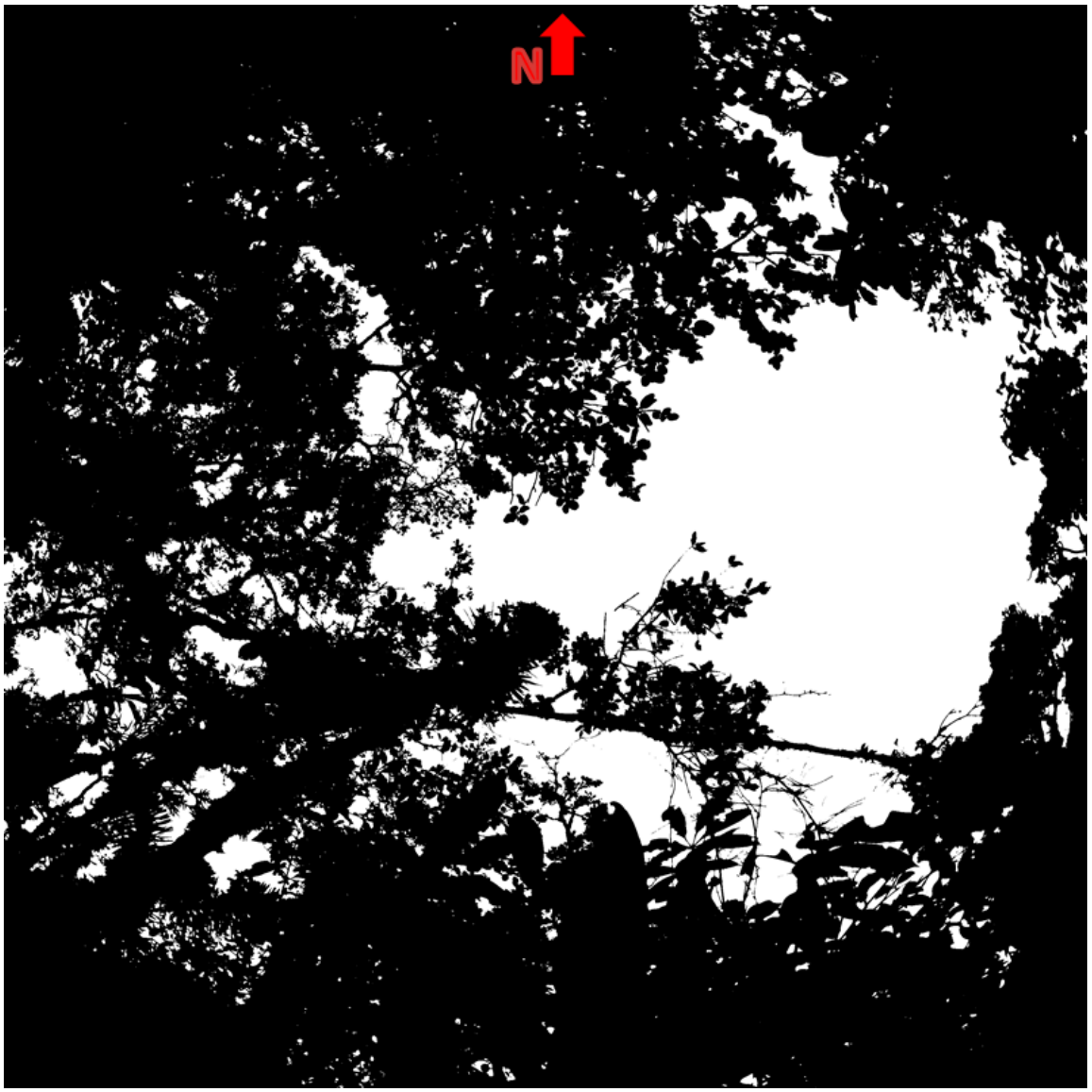

Figure 2.5 Output image produced by Gap Light Analyzer software. The program transformed hemispherical photos to binary images, where pixels in black represent vegetation cover and pixel in white represent the open sky.

\subsubsection{Seedling Transplantation Experiment (STE)}

It is known that plant species composition shows strong variation between adjacent microhabitats (Homeier, 2008; Homeier et al., 2010), particularly due to edaphic specialization (Svenning et al., 2009; Baltzer et al., 2005) or responses to critical resources (Werner \& Homeier, 2015; Metz et al., 2008).

In order to test the differences in resource limitation and habitat specificity of juvenile stages of tree species, and so predict probable habitat shifts which may result from nutrient limitation, a seedling transplantation experiment (STE) was carried out in Bombuscaro. This experiment was established in 2011 to evaluate biotic and abiotic factors affecting the performance of Pouteria torta seedlings after nutrient treatment. This species is the most 
abundant species in Bombuscaro and was chosen to evaluate responses to nutrient availability driving specific strategies for survival and growth.
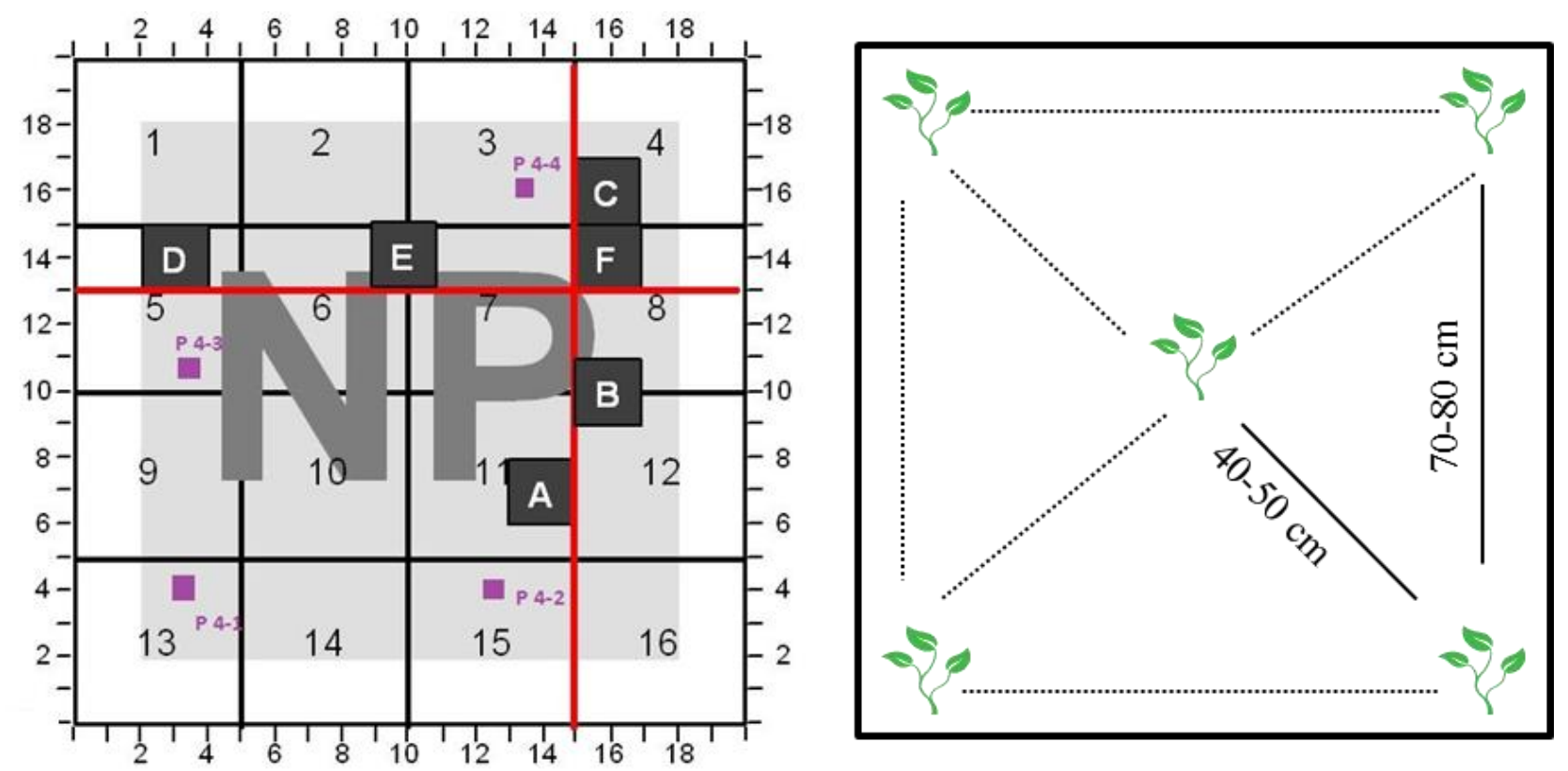

Figure 2.6 Setup of seedling transplantation experiment in NUMEX experimental plots. (Left) Location of the four additional experimental STE-plots inside a NUMEX plot. STE-plots are mapped in purple. (Right) Location of seedlings planted in $1 \mathrm{~m}^{2}$ plot.

For establishing a STE in the experimental NUMEX plots, four additional regeneration plots $\left(1 \mathrm{~m}^{2}\right)$ were set up in Bombuscaro (STE1). Every plot was cleared of tree seedlings and herbs to eliminate competition with established individuals. Five seedlings of the target species were planted in each plot, taking into consideration distance between 40

$80 \mathrm{~cm}$ from each other (Figure 2.6). Individual measurements were taken every 4 months

(i.e., height, stem diameter, leaf sizes and number, and percentage of herbivory).

In the year previous to the experiment, seeds were collected and seedlings of the target species were sowed and produced.

After a complete year, all surviving seedlings were harvested and additional parameters were evaluated using fresh leaves. All leaves were scanned in fresh state with a flatbed scanner for herbivory analysis. Seedlings were separated into roots, stems and leaves, and dried at $64{ }^{\circ} \mathrm{C}$ for 24-48 hours. Parameters assessed in dried material were: root, stem and leaf weights, leaf 
Chapter 2

nutrient contents and presence of mycorrhizae. A summary of the experimental design is shown in Figure 2.7.

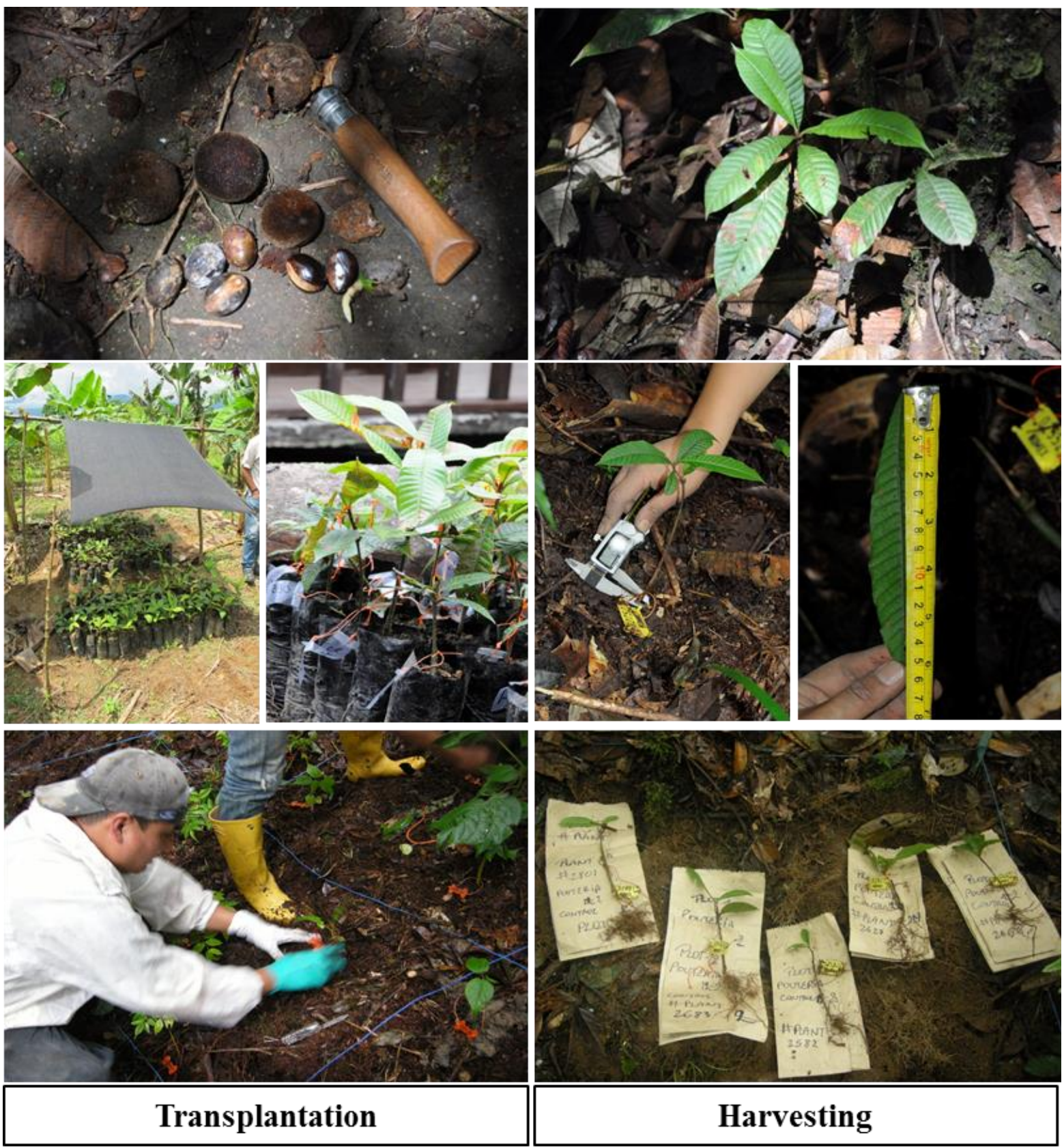

Figure 2.7 Summary of Seedling Transplantation Experiment 1 (STE1) setting up in Bombuscaro with Pouteria torta as target species. Left-top: seedlings collected from productive trees in 2010, Left-middle: seedling produces in local nursery, Left-bottom: seedlings transplantation in regeneration plots; Right-top: seedlings after one year of planting, Right-middle: measurements in situ to every individual, Right -bottom: harvested seedlings. Photos: D. Cárate-Tandalla, J. Homeier. 


\subsubsection{Seedling Morphology}

The last step to investigate the effects of nutrients in the performance of common species is the analysis of species-specific foliar nutrient content and changes in seedlings morphology traits. For this aim, a representative number of individuals of the two most common species at every study site were collected inside every experimental plot. The sampling collection consists in harvesting intact individuals of every species.

The two most common species in every altitudinal range were chosen. The selection was based on the highest number of individuals recorded along the three monitoring years in every site:

For Bombuscaro: Clarisia racemosa (Moraceae) and Pouteria torta (Sapotaceae); for San Francisco: Graffenrieda emarginata (Melastomataceae) and Palicourea angustifolia (Rubiaceae); for Cajanuma: Graffenrieda harlingii (Melastomataceae) and Hedyosmum purpuracens (Chloranthaceae).

The number of individuals established to be harvested per treatment was twenty (i.e., five in every experimental plot). However, for some species the number varied (Figure 2.8).

Previous to harvesting, seedlings were measured and photographed. After harvesting, seedlings were separated into leaves, shoots and roots. Fresh leaves were scanned to determine exact leaf areas (i.e., hole area, total area, foliar area). Scanned pictures were analyzed using the software WinFolia 2005b (WinFOLIA T. M., 2001). All plant parts were then oven-dried at $60-65^{\circ} \mathrm{C}$ for $24-48$ hours.

Once transferred to the laboratories of the Department of Plan Ecology in Göttingen, seedlings were weighed (roots, stems, leaves) and leaves were ground. Further analyses of the following nutrients were conducted: $\mathrm{N}, \mathrm{P}, \mathrm{C}, \mathrm{K}, \mathrm{Mg}, \mathrm{Mn}, \mathrm{Na}, \mathrm{Fe}, \mathrm{Al}, \mathrm{Ca}$ and $\mathrm{C} / \mathrm{N}$ ratio. Nitrogen and carbon contents were quantified with a $\mathrm{C} / \mathrm{N}$ analyser (Vario El III, Elemetaranalysesysteme GmbH Hanau, Deutschland). Phosphorus was determined with an ICP (Optima 5300DVICP-OES Perkin Elmer, Waltham, Massachusetts, USA) after digestion with $\mathrm{HNO}_{3}$. 


\section{Chapter 2}

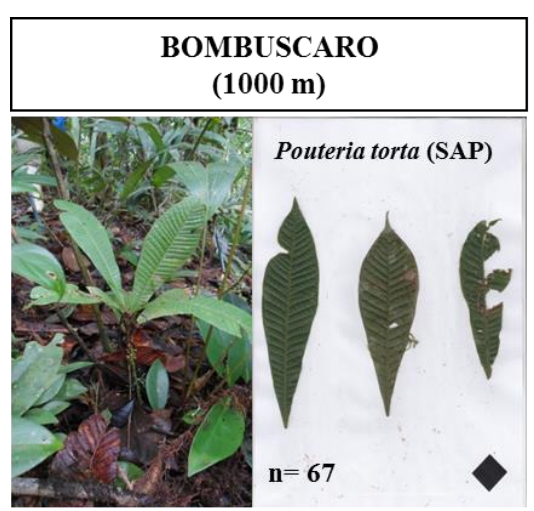

SAN FRANCISCO
$(2000 \mathrm{~m})$
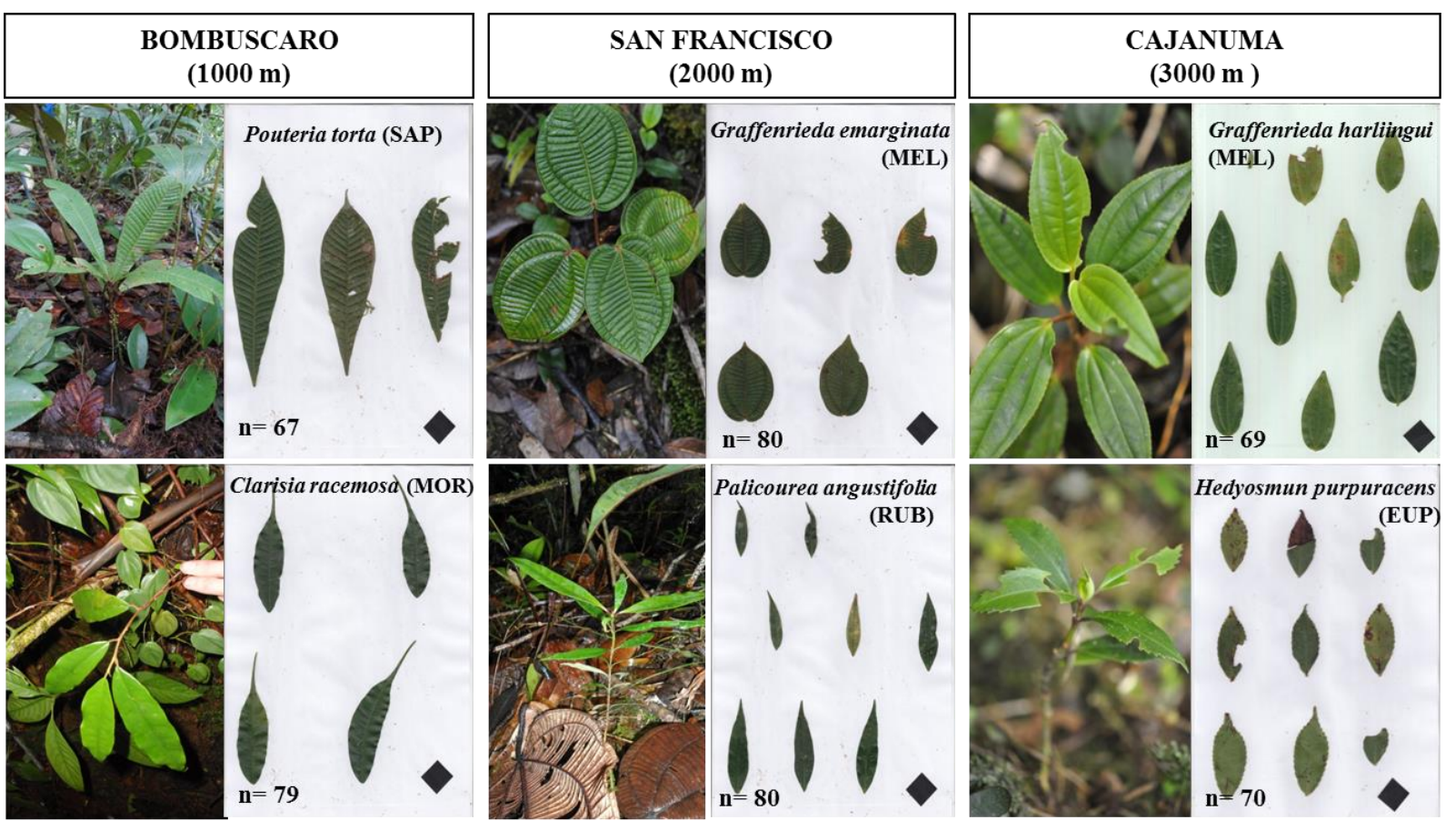

Figure 2.8 The most common species in the three altitudinal stands harvested for leaf morphological analyses. Leaf pictures: seedlings growing on the field; Right pictures: leaf scans to analyze leaf area loss. Number of individuals per species is indicated at the bottom of every scan. Photos: D.Cárate-Tandalla. 


\section{Chapter \\ 3}

RESPONSES OF CONTINUED NITROGEN AND PHOSPHORUS ADDITION ON TREE REGENERATION IN A TROPICAL MONTANE FOREST IN SOUTHERN ECUADOR

With Roman Link, Christoph Leuschner and Jürgen Homeier 


\subsection{Summary}

The effects of continued nutrient addition on woody regeneration were investigated in the ongoing Ecuadorian Nutrient Manipulation Experiment (NUMEX). In this experiment, moderate amounts of $\mathrm{N}\left(50 \mathrm{~kg} \mathrm{ha}^{-1}\right), \mathrm{P}\left(10 \mathrm{~kg} \mathrm{ha}^{-1}\right)$, and $\mathrm{N}$ plus $\mathrm{P}$ have been added annually to representative montane forest stands since 2008.

By studying seedlings dynamics we aim to understand which nutrient-related processes are relevant for seedling establishment and how increasing nutrient availability will affect the woody plant community. Compositional shifts in communities of long-lived organisms like trees need decades to become visible. For this reason, we focused our study on seedlings, since they should be more sensitive to a changing environment than mature trees. We monitored the seedling community in natural forests at $2000 \mathrm{~m}$ for three consecutive years (2011-2013), 3-5 years after the onset of NUMEX, using permanent seedling plots. Densities, recruitment, survival, plant height, height growth, leaf production, herbivory and the species richness of seedlings were examined in a fully factorial analysis to identify the effects of $\mathrm{N}$ and $\mathrm{P}$ addition.

The effects observed in this montane forest seedling community were not as strong as expected and partly contrary to those reported from lowland forests. After 5 years of fertilization, seedlings showed a general decrease in recruitment on the community level, resulting in lower densities after $\mathrm{N}$ addition. Negative effects of nutrient addition on recruitment in 2013 showed that soil nutrients are possibly not a major limiting factor for the establishment of rare tree species. There was no support for density as a driver of seedling mortality in the studied montane forest. Seedling height growth was not affected by nutrient addition, but after $\mathrm{N}$ addition, seedlings were, on average, taller than in the control plots, partly as a result of the reduced recruitment in this treatment. Nitrogen addition increased leaf area loss by herbivory and seedling species richness decreased in the fifth study year after $\mathrm{N}$ addition.

Locally common species did not take advantage of the changed nutrient conditions; they seem to be well adapted to the relatively nutrient poor soils but not able to adjust their growth and leaf properties to increased nutrient availability. This suggests that in the longterm, these species will most likely be replaced by invading species with faster growth. 
Key words: seedling dynamics, nutrient addition, nitrogen, phosphorus, communitylevel responses, seedling growth, herbivory, diversity.

\subsection{Introduction}

Processes affecting the seedling stage act as strong selective filters in woody plant regeneration, controlling patterns of recruitment and mortality (Ceccon et al., 2004) and influencing future species composition and structure of plant communities (Metz et al., 2008; Swaine et al., 1996; Whitmore, 1996; Connell et al., 1984; Beckage \& Clark, 2003; Palmiotto et al., 2004; Bellingham \& Richardson, 2006).

In general, there are three main resources young plants require and compete for: light, water and essential nutrients, most of them closely linked to habitat characteristics such as topography and elevation (Lieberman et al., 1985; Hubbell \& Foster, 1986). Initial studies conducted in tropical forests identified light as a key parameter determining the success of tree seedling establishment in canopy gaps (Swaine et al., 1996; Whitmore, 1996). However, later studies focussed on separating the effects of above- and belowground seedling competition by using pot experiments (Lawrence, 2003), transplantation (Baltzer et al., 2005; Baraloto et al., 2006), trenching (Coomes \& Grubb, 1998; Lewis \& Tanner, 2000; Barberis \& Tanner, 2005) or experimental nutrient addition (Andersen et al., 2010; Ceccon, 2003; Yawitt \& Wright, 2008; Santiago et al., 2011; Alvarez-Clare et al., 2013). The results of these experiments showed that belowground competition for nutrients must be considered as a vital factor influencing seedling growth, especially on less fertile soils.

A meta-analysis of pot studies with tropical tree seedlings showed that a high proportion of species investigated had the potential for a positive growth response to added $\mathrm{N}$ or P or both nutrients (Lawrence, 2003). From a field experiment, Ceccon et al. (2004) reported altered rates of mortality and recruitment after $\mathrm{N}$ and $\mathrm{P}$ fertilization with species responses differing strongly in magnitude. Other studies (Beckage \& Clark, 2003; Palmiotto et al., 2004; Bellingham \& Richardson, 2006; Holste et al., 2011) found soil nutrient availability to mediate seedling performance (i.e., seedling recruitment, survival and growth) thereby influencing the further spatial distribution of trees in tropical forests. 
Nevertheless, the degree to which species respond differentially to soil resources seems to depend on species-specific nutrient requirements, and the effects of long-term changes in nutrient availability on species composition remain unclear (Baraloto, 2006; Buslem et al., 1995; Mo et al., 2008; Yawitt \& Wright, 2008; Holste et al., 2011).

The Ecuadorian Nutrient Manipulation Experiment (NUMEX) was started in 2008 adding moderate amounts of $\mathrm{N}\left(50 \mathrm{~kg} \mathrm{ha}^{-1} \mathrm{yr}^{-1}\right)$ or/and $\mathrm{P}\left(10 \mathrm{~kg} \mathrm{ha}^{-1} \mathrm{yr}^{-1}\right)$ to old-growth montane forest stands with the aim to simulate future environmental conditions with increasing airborne $\mathrm{N}$ and $\mathrm{P}$ inputs (Homeier et al., 2012; Camenzind et al., 2014; Matson et al., 2014). After the first year of NUMEX, the studied forest already responded to the nutrient additions, indicating the vulnerability of tropical montane forests to the expected increase in nutrient inputs: $\mathrm{N}$ and $\mathrm{P}$ additions led to an increase in foliar $\mathrm{N}$ and $\mathrm{P}$ concentrations and altered standing fine root biomass, stem growth, and litterfall. The reported effects so far suggest that most tree species in the study area are limited by $\mathrm{P}$ or co-limited by $\mathrm{N}$ and $\mathrm{P}$ (Homeier et al., 2012; Camenzind et al., 2014). Partly contrasting responses of different tree species suggest marked changes in species composition and diversity of these forests by nutrient inputs in the long-term.

In 2011, three years after the onset of NUMEX, we started the monitoring of the woody seedling community, since we expected that seedlings would be more responsive to nutrient addition than mature montane forest trees and that therefore changes in the performance and composition of tree species would first become visible in seedlings.To demonstrate that continued nutrient addition affects tree regeneration dynamics, we addressed the following hypotheses: a) Seedling dynamics (survival and recruitment) would be altered, b) seedling growth performance and folivory would be altered, and as a result, c) seedling density would change and d) compositional changes in the tree seedling assemblage would become visible as a response to chronic nutrient addition to Andean montane forests.

\subsection{Methods}

\subsubsection{Study site}

The study site is located in the tropical montane forest of the San Francisco Reserve ( $\left.3^{\circ} 58^{\prime} \mathrm{S}, 7^{\circ} 04^{\prime} \mathrm{W}\right)$, on the eastern slope of the Andes in southern Ecuador (2020-2120 
m.a.s.1.). Paleozoic metamorphic schists and sandstones with some quartz veins form the parent materials for soil development (Wolf et al., 2011; Wullaert et al., 2010). Soils are nutrient-poor stagnic cambisols with thick organic layers locally accumulating high nutrient stocks that are usually slowly bioavailable (Wilcke, 2002; Homeier et al., 2012; Werner \& Homeier, 2015). The research area has a tropical humid climate, mean annual precipitation is $\sim 2200 \mathrm{~mm}$ and mean annual temperature is $\sim 15^{\circ} \mathrm{C}$ (Homeier et al., 2012), rainfall shows little seasonality and no regularly occurring dry periods (Emck, 2007). During the last decades, background $\mathrm{N}$ deposition has increased in the study area as $\mathrm{NH}_{4}^{+}$(Wilcke et al., 2013) and was estimated in an average of $14-45 \mathrm{~kg} \mathrm{ha}^{-1}$ of $\mathrm{N}$ and $0.4-4.9 \mathrm{~kg} \mathrm{ha}^{-1}$ of $\mathrm{P}$ (Homeier et al., 2012).

The San Francisco Reserve harbors one of the best-studied tropical montane forests worldwide, known for its exceptional richness and endemism in tree species as well as other plant and animal groups (Brehm et al., 2008; Homeier et al., 2010; Bendix et al., 2013). Mean canopy height of the evergreen lower montane forest at the study site is $10-14 \mathrm{~m}$, characteristic tree families are: Euphorbiaceae, Lauraceae, Melastomataceae and Rubiaceae (Homeier et al., 2008; 2012; 2013).

\subsubsection{The nutrient manipulation experiment}

NUMEX was started in the San Francisco Reserve in 2008 with the aim of studying the effects of moderate addition of $\mathrm{N}$ and $\mathrm{P}$ on forest productivity and biogeochemical cycles (Homeier et al., 2012). The fully-factorial experiment consists of 16 plots of $400 \mathrm{~m}^{2}(20 \times 20$ m) in four treatments (control, $+\mathrm{N},+\mathrm{P}, \mathrm{N}+\mathrm{P}$ ) located in old-growth montane forest stands with closed canopy. One replicate of each treatment is arranged randomly in each of the four blocks; plots are separated by a distance of at least $10 \mathrm{~m}$. $\mathrm{N}$ and $\mathrm{P}$ are added to the plots at an annual rate of $50 \mathrm{~kg} \mathrm{~N} h a^{-1}$ (as urea, $\mathrm{CH}_{4} \mathrm{~N}_{2} \mathrm{O}$ ) and $10 \mathrm{~kg} \mathrm{P}^{-1}$ (as $\mathrm{NaH}_{2} \mathrm{PO}_{4}$ ). The nutrients are dispersed by hand homogeneously within the plots on two application dates per year. In the study plots mean tree density $(\mathrm{dbh} \geq 10 \mathrm{~cm})$ is 1143 trees $\mathrm{ha}^{-1}$ and mean basal area is $22.8 \mathrm{~m}^{2} \mathrm{ha}^{-1}$ and the most common tree species among adult individuals $(\mathrm{dbh} \geq 10 \mathrm{~cm})$ are Graffenrieda emarginata (Melastomataceae) (29\% of all stems), Dictyocaryum lamarckianum (Arecaceae), Hieronyma fendleri (Phyllanthaceae), Alchornea lojaensis (Euphorbiaceae) and Myrcia sp. nov. (Myrtaceae) (Homeier et al., 2012; 2013). 


\subsubsection{Seedling monitoring}

Inside every experimental $20 \times 20 \mathrm{~m}$ plot, 12 permanent regeneration plots of $1 \times 1 \mathrm{~m}$ were established (resulting in a total of 192 regeneration plots, 48 per treatment) in AprilMay 2011, three years after the onset of NUMEX. Regeneration plots were placed in pairs following the perpendicular random transects installed in every NUMEX experimental plot. Within each regeneration plot all woody plant seedlings and saplings with stem height between $5-120 \mathrm{~cm}$ and $\mathrm{dbh} \leq 1 \mathrm{~cm}$ were mapped, tagged, and identified.

All regeneration plots were recensused in April-May 2012 and May-June 2013. For all existing seedlings and new recruits, the following parameters were recorded: stem length (from the forest floor to the apical tip, in $\mathrm{cm}$ ), stem diameter (at the base, in $\mathrm{mm}$ ), number of leaves, and estimated leaf area loss by folivory (\%) quantified as the percentage of the area damaged on leaves compared with total foliar area in every individual.

Relative rates of height growth (RGRh) and increment in leaf number (RGRl) were calculated following the equation suggested by Hoffman \& Poorter (2002). RGRh and RGRl were calculated separately for each census interval as:

$$
\left(\ln \left(\mathrm{H}^{1}\right)-\ln \left(\mathrm{H}^{0}\right)\right) /\left(\mathrm{t}^{1}-\mathrm{t}^{0}\right)
$$

where $\mathrm{H}^{1}$ and $\mathrm{H}^{0}$ represent the initial and final height $(\mathrm{cm})$ or number of leaves and $\left(\mathrm{t}^{1}-\mathrm{t}^{0}\right)$ represents the time between censuses. The total number of individuals surviving between censuses was 460 for 2011-2012 and 614 for 2012-2013. All plants with large negative growth $\left(<-5 \mathrm{~cm} \mathrm{y}^{-1}\right)$ were excluded from further analyses.

Species identification of tropical tree seedlings is a challenging task since many species (e.g., Rubiaceae and Myrtaceae) share similar vegetative features in early stages. With our knowledge of tree species composition at the study site we determined $40 \%$ of the seedlings to species level, $58 \%$ of the remaining seedlings were determined to genus level and the rest were classified to morpho-species (Table S3.1).

To quantify light availability, we took hemispherical photos in April 2011. Photos were taken at the midpoint of every regeneration plot $1 \mathrm{~m}$ above ground under uniform sky conditions using a Nikon D5000 camera and an $8 \mathrm{~mm}$ fisheye lens. Resulting images were analyzed using Gap Light Analyzer software (Frazer et al., 1999). Analyses of light 
parameters indicated a mean canopy openness of $9.8 \% \pm 5.6(\mathrm{SD})$ with a range of $1.7-$ $33.1 \%$.

\subsubsection{Statistical analyses}

Overview.- To test how the seedling community responds to nutrient addition, we investigated whether the different nutrient treatments resulted in differences in seedling density, recruitment, survival, height, height growth, leaf production, folivory, and species counts on the level of regeneration plots. The analysis of seedling data was based on data sets from censuses performed in three consecutive years (2011, 2012 and 2013), encompassing a total number of 606,825 , and 2165 individuals, respectively.

Due to the high number of species, and the large variability in the number of seedlings in the regeneration plots (range $=0$ to 47 ), it was not possible to perform valid analyses at the species level even for the most common species in the dataset. Therefore, to investigate species-specific differences in the response to nutrient addition, we performed separate analyses for three subsets of data:

a) pooled data from all species at the community level,

b) pooled data for the six most common species and

c) pooled data for the remaining species (rare species).

The six most common species comprised $41 \%, 42 \%$ and $68 \%$ of all individuals in 2011, 2012 and 2013, respectively, and included Graffenrieda emarginata (Melastomataceae), Myrcia sp. nov. (Myrtaceae), Prunus sp. nov. (Rosaceae), Faramea uniflora, Palicourea luteonivea and Palicourea angustifolia (all Rubiaceae) (Table 3.1).

As growth conditions varied strongly between years, we set up separate analyses for the three study years. To account for the nested design of the NUMEX experiment, all analyses were based on mixed effects models with a random intercept for plots nested in blocks. In all analyses, the effects of the nutrient treatment were analyzed with a full factorial set-up using nitrogen addition, phosphorus addition and their interaction as fixed effects. The fixed effects were then consecutively simplified by stepwise backward selection based on Akaike's information criterion (AIC). 
Analysis of seedling height, height growth, leaf production and folivory.- The variability in seedling density between regeneration plots led to an extremely unbalanced design for analyses of the variables measured on individual level. Therefore, it was decided to work with average values for regeneration plots $(n \leq 192)$. In some cases, only one or two individuals with extreme values were present in a regeneration plot, resulting in obvious outliers. If extreme values backed up by few observations were found to seriously affect the results, they were excluded from the models. It was observed that the variance in the average values decreased with the number of observations per sampling unit; moreover, in several cases variances were not homogeneous between blocks. To account for the heteroscedasticity, we decided to analyze the differences in seedling height, height growth, leaf production, and herbivory with linear mixed models (LMM) using the lme function from R package nlme (Pinheiro et al., 2014), which allows for the use of variance covariates.

For each of the variables, we fitted a set of LMM with fixed and random terms as described above using restricted maximum likelihood estimation (REML), with separate variances per block, and using the number of observations as a variance covariate (testing both an exponential and a power law relationship). We then simplified the random term of the models by removing the separate variances, the variance covariate, or both, and selecting the best random term based on AIC following the framework of Zuur et al. (2009). The resulting model was then refitted with maximum likelihood, the fixed term was simplified as described above, and the simplified models were refitted with REML. Inference was based on conditional t-tests of the significance of parameter estimates. While the relative growth of leaves and seedling height were assumed to be approximately normal, height and leaf area loss by folivory had to be normalized by a ln- and a logit-transformation, respectively (Table S3.2). All analyses were conducted in R version 3.0.3. (R development Core Team, 2013).

Analysis of density, recruitment, survival, and species counts.- The analysis of counts and proportions of individuals in regeneration plots $(n=192)$ was performed with generalized linear mixed models (GLMM) using AD Model Builder (Fournier et al., 2012) as implemented in the R package glmmADMB v. 0.8.0 (Skaug et al., 2014). Density was expressed as the number of living seedlings per regeneration plot, recruitment as the number of individuals in a census that were not present in the previous census, and survival as the 
proportion of individuals that survived from one census to the next. Species counts represent the number of morphospecies per sampling unit (only analyzed on community level). The unequal distribution of seedlings over the regeneration plots led to a large number of zeroes in the count datasets (i.e., density, recruitment and species counts). Moreover, tests with a simple estimator of overdispersion based on the ratio of the squared Pearson residuals and the approximated degrees of freedom of the models (e.g., Zuur et al., 2009: p. 233) suggested that the models of density and recruitment might be affected by overdispersion. To account for possible overdispersion and zero inflation, four alternatives GLMM were fitted with Poisson and negative binomial error distributions and their zero-inflated equivalents, and fixed and random terms as described above. The model that achieved best fit was then selected based on AIC, and the fixed term was simplified as detailed above. For the proportion of surviving seedlings, analogous models were set up with binomial errors. Inference was based on Wald Z-tests of parameter estimates (Table S3.3). Due to the large variation in density, in some cases there were extreme observations that had to be excluded as they distorted model results.

\subsection{Results}

We identified 82 species and morphospecies of woody seedlings from 42 genera and 29 plant families which represent about $25 \%$ of the total tree species richness registered for San Francisco reserve (Homeier \& Werner, 2008) (Table S3.1).

\subsubsection{Effects of nutrient addition in seedlings density}

Over all plots, seedling density increased slightly from 2011 to 2013, largely driven by recruitment of the common species (Figure 3.1, Table 3.1). However, comparing between treatments, plots with added $\mathrm{N}$ (both $\mathrm{N}$ and $\mathrm{N}+\mathrm{P}$ plots) showed significantly lower seedling densities than control and added P treatment, for common species in 2011 ( $\mathrm{p}=0.025)$, but not 2012 or 2013, and rare species in 2012 ( $\mathrm{p}=0.047)$, but not 2011 or 2013. Similar trends were observed at the community level but no significant differences were found. 
Chapter 3

\subsubsection{Survival}

We found no significant effects of nutrient addition on mortality (data not shown) and survival neither at the community level nor at the non-common species level. Only the common species were negatively responding to $\mathrm{N}$ addition $(\mathrm{p}=0.043)$ and marginally to $\mathrm{P}$ addition ( $\mathrm{p}=0.095)$ in 2013. The combined addition of both nutrients resulted in the lowest seedling survival rate of about $60 \%$ in 2013 .

\subsubsection{Effects of nutrient addition on seedling recruitment}

Community level recruitment in 2013 responded negatively mainly to $\mathrm{N}$ addition $(p=0.010)$ and also marginally to $P(p=0.069)$. Common species recruitment was not affected by nutrient addition whereas rare species reacted in the same way like seedlings on community level did with negative responses after both $\mathrm{N}$ addition $(\mathrm{p}<0.001)$ and $\mathrm{P}$ addition $(\mathrm{p}=0.021)($ Fig.3.1b).

\subsubsection{Effects of nutrient addition on seedling survival}

We found no significant effects of nutrient addition on survival neither at the community level nor in the rare species category. Only the common species were negatively responding to $\mathrm{N}$ addition ( $\mathrm{p}=0.043$ ) in 2013. The combined addition of both nutrients resulted in the lowest seedling survival rate of about $60 \%$ in 2013.

\subsubsection{Height differences among treatments}

Average seedling heights in all treatments decreased from 2011 to 2013 due to the newly recruited seedlings. Nevertheless, on community level $(\mathrm{p}=0.015, \mathrm{p}=0.061, \mathrm{p}=0.010$, respectively) and for the rare species ( $\mathrm{p}=0.020, \mathrm{p}=0.084, \mathrm{p}=0.002$, respectively), linear mixed models revealed comparatively taller seedling after $\mathrm{N}$ addition during the consecutive study years.

Common species height responded with the same trend but expressed in a different significant effects. On one hand in 2012 there were no significant responses to $+\mathrm{N}$ compared 
with the control but significant differences were found in a negative response after $+\mathrm{P}$ $(\mathrm{p}=0.027$ ) addition, which also provoked a positive significant response in the $\mathrm{N}+\mathrm{P}$ treatment $(\mathrm{p}=0.036)$. In 2013 seedling height of the common species responded only to $+\mathrm{N}(\mathrm{p}=0.064)$ addition, and this was not significant in the $\mathrm{N}+\mathrm{P}$ treatment (Fig 3.2a).

Table 3.1 Summary of mean seedling attributes of the six most common species in the seedling community

\begin{tabular}{|c|c|c|c|c|c|c|c|c|c|c|c|c|}
\hline \multirow[t]{2}{*}{ Species } & \multirow[t]{2}{*}{ Treat } & \multicolumn{3}{|c|}{ Height (cm) } & \multicolumn{3}{|c|}{ Diameter $(\mathrm{mm})$} & \multicolumn{3}{|c|}{ Density $\left(\mathrm{m}^{2}\right)$} & \multicolumn{2}{|c|}{$\begin{array}{l}\text { Recruitment } \\
\left(\mathrm{m}^{2}\right)\end{array}$} \\
\hline & & 2011 & 2012 & 2013 & 2011 & 2012 & 2013 & 2011 & 2012 & 2013 & 2012 & 2013 \\
\hline \multirow[t]{4}{*}{$\begin{array}{c}\text { Graffenrieda } \\
\text { emarginata }\end{array}$} & Con. & 13.00 & 9.42 & 7.16 & 2.92 & 2.28 & 1.73 & 4 & 6 & 19 & 2 & 14 \\
\hline & $\mathrm{N}$ & 17.20 & 7.13 & 7.05 & 2.70 & 1.76 & 2.20 & 5 & 8 & 10 & 5 & 4 \\
\hline & $\mathrm{P}$ & 17.75 & 11.68 & 13.25 & 2.50 & 2.42 & 2.56 & 23 & 27 & 32 & 7 & 8 \\
\hline & NP & 12.59 & 12.13 & 7.36 & 2.51 & 3.54 & 1.61 & 4 & 4 & 7 & 2 & 4 \\
\hline \multirow[t]{4}{*}{$\begin{array}{l}\text { Myrcia } \\
\text { sp.nov. }\end{array}$} & Con. & 23.05 & 18.77 & 7.62 & 1.27 & 1.57 & 0.94 & 10 & 15 & $216 \div$ & 7 & $204 \%$ \\
\hline & $\mathrm{N}$ & 15.77 & 18.03 & 8.90 & 1.14 & 2.26 & 1.16 & 15 & 15 & $138 \div$ & 2 & $125 t$ \\
\hline & $\mathrm{P}$ & 15.77 & 12.81 & 7.81 & 1.16 & 1.49 & 0.98 & 15 & 21 & $207 t$ & 7 & $193 \%$ \\
\hline & NP & 22.68 & 21.88 & 10.24 & 1.23 & 1.93 & 1.15 & 11 & 12 & $79 \$$ & 1 & $72 \ddagger$ \\
\hline \multirow[t]{4}{*}{ Prunus sp. } & Con. & 21.50 & 12.96 & 9.74 & 2.56 & 1.87 & 1.46 & 10 & 14 & $111 t$ & 7 & $101+$ \\
\hline & $\mathrm{N}$ & 19.25 & 17.57 & 10.60 & 1.62 & 2.18 & 1.44 & 4 & 7 & $83 \%$ & 4 & $78 \div$ \\
\hline & $\mathrm{P}$ & 41.83 & 20.13 & 10.51 & 2.78 & 2.69 & 1.29 & 3 & 8 & $70 \%$ & 5 & $64 t$ \\
\hline & NP & 41.67 & 30.40 & 10.06 & 5.64 & 3.70 & 1.19 & 3 & 5 & $184+$ & 2 & $181 t$ \\
\hline \multirow[t]{4}{*}{$\begin{array}{l}\text { Faramea } \\
\text { uniflora }\end{array}$} & Con. & 12.90 & 10.93 & 10.74 & 1.52 & 1.61 & 1.68 & 21 & 27 & 45 & 9 & 21 \\
\hline & $\mathrm{N}$ & 10.20 & 8.67 & 10.77 & 1.53 & 1.56 & 1.54 & 5 & 9 & 15 & 4 & 8 \\
\hline & $\mathrm{P}$ & 10.92 & 10.56 & 11.98 & 1.60 & 1.80 & 1.65 & 18 & 16 & 25 & 3 & 10 \\
\hline & NP & 17.81 & 15.52 & 18.11 & 1.68 & 1.89 & 1.95 & 18 & 20 & 17 & 6 & 5 \\
\hline \multirow[t]{4}{*}{$\begin{array}{l}\text { Palicourea } \\
\text { luteonivea }\end{array}$} & Con. & 23.10 & 19.90 & 17.72 & 1.74 & 2.21 & 1.82 & 12 & 15 & 23 & 7 & 10 \\
\hline & $\mathrm{N}$ & 14.68 & 10.53 & 12.71 & 1.45 & 1.82 & 1.84 & 10 & 18 & 26 & 9 & 13 \\
\hline & $\mathrm{P}$ & 11.14 & 11.71 & 12.66 & 1.72 & 1.99 & 1.68 & 11 & 12 & 16 & 2 & 6 \\
\hline & NP & 12.17 & 11.55 & 10.46 & 1.51 & 1.57 & 1.43 & 6 & 11 & 24 & 7 & 17 \\
\hline \multirow[t]{4}{*}{$\begin{array}{l}\text { Palicourea } \\
\text { angustifolia }\end{array}$} & Con. & 11.50 & 11.06 & 13.21 & 1.43 & 1.52 & 1.64 & 11 & 18 & 28 & 10 & 13 \\
\hline & $\mathrm{N}$ & 10.25 & 6.91 & 9.45 & 0.97 & 1.09 & 1.13 & 4 & 16 & 40 & 14 & 27 \\
\hline & $\mathrm{P}$ & 7.44 & 7.56 & 8.92 & 1.04 & 1.18 & 1.19 & 9 & 16 & 24 & 8 & 14 \\
\hline & NP & 12.80 & 7.87 & 7.22 & 1.36 & 1.25 & 1.14 & 5 & 15 & 25 & 12 & 15 \\
\hline
\end{tabular}

NOTES: Values are mean of individuals alive in every treatment in every year. $\$=$ numbers indicate big proportion changes in density and recruitment in two common species after a massive event of fruiting in 2012. 


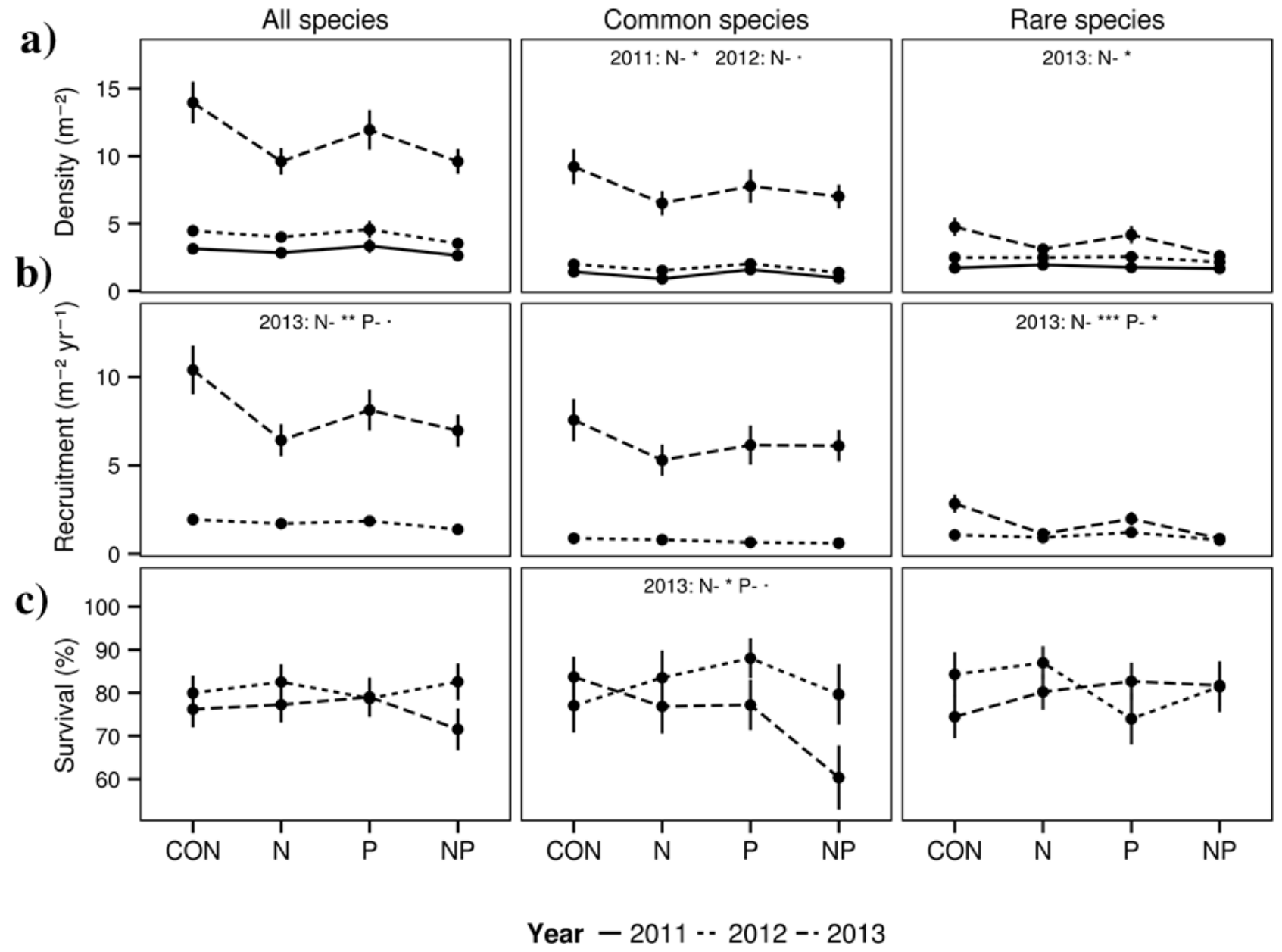

Figure 3.1 Effects of moderate nutrient addition on the whole seedling community and on the common and the rare species (mean $\pm \mathrm{SE}$ ) censussed during 3 years after 5 years of fertilization in San Francisco. (A) Seedling density, (B) seedling recruitment, and (C) survival of seedlings since the last census. Significance in all groups is indicated per year according to a two-way ANOVA with $\mathrm{N}$ and $\mathrm{P}$ as explanatory variables. A point indicates marginal significance for the effects and asterisks shows significant differences $(* \mathrm{p}<0.05, * * \mathrm{p}<0.01)$. Also shown are the direction of the effects (-) or (+).

\subsubsection{Height growth and leaf production}

Relative height growth rates varied strongly between the study years but showed no significant effects of the treatment. The common species decreased their leaf production after $\mathrm{P}$ addition in $2012(\mathrm{p}=0.025)$.

\subsubsection{Herbivory}


Leaf area loss of the seedling community increased with $\mathrm{N}$ addition in $2012(\mathrm{p}=0.026)$ and 2013 ( $\mathrm{p}=0.022$ ). The same effect of $\mathrm{N}$ addition was found in 2013 when only the rare species were considered $(\mathrm{p}=0.013)($ Fig 3.2d).

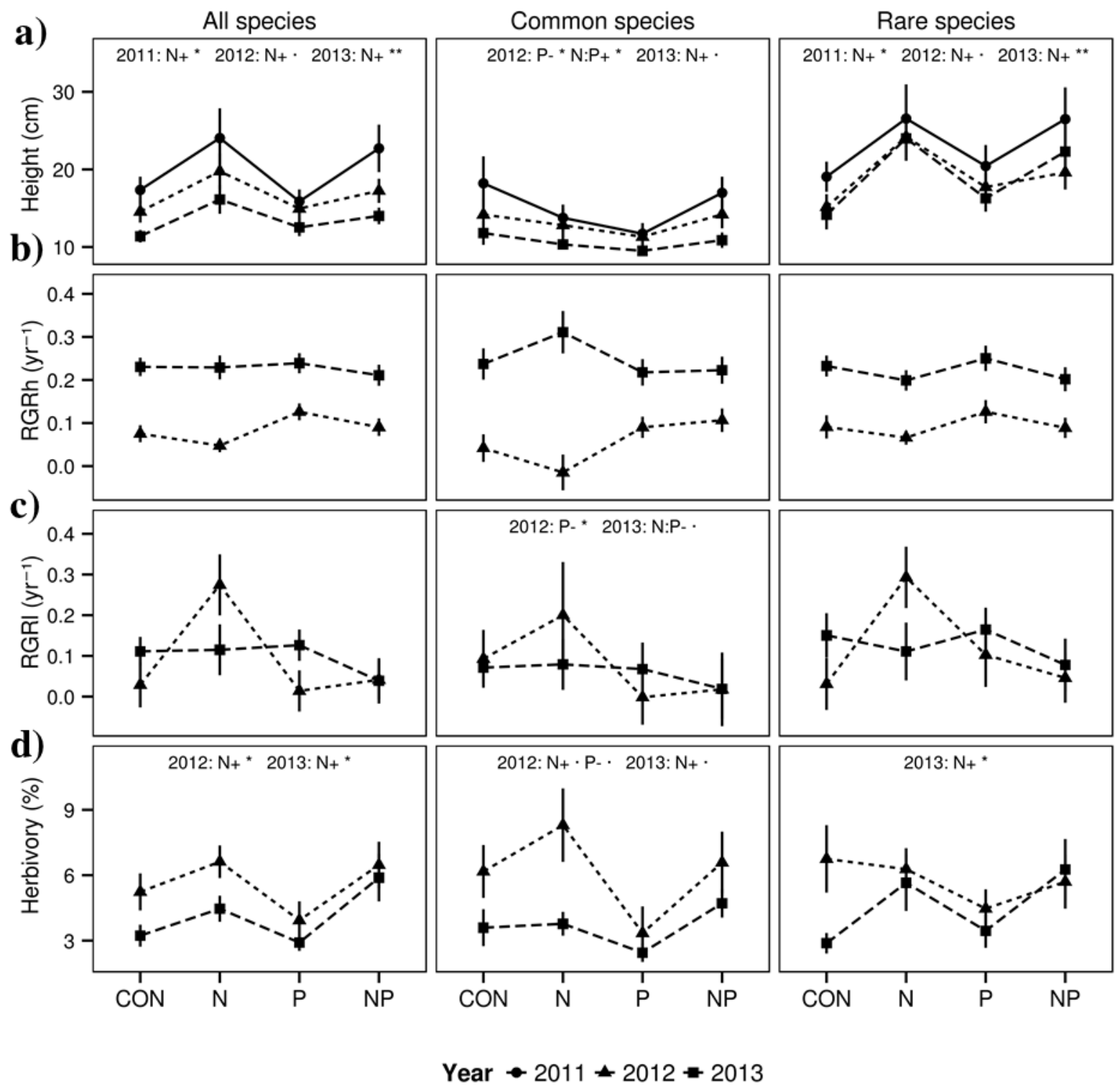

Figure 3.2 Effects of moderate nutrient addition on the whole seedling community and on the common and the rare species (mean \pm SE) censussed during 3 years after 5 years of fertilization in San Francisco. (A) Seedling height, (B) relative height growth rate (RGRh), (C) relative increase in leaf number (RGRl) and (D) extent of leaf herbivory (\% of area lost). Significance in all groups is indicated per year according two-way ANOVA with N and $\mathrm{P}$ as explanatory variables. A point indicates marginal significance for the effects and one asterisks shows significant differences $(* ; \mathrm{p}<0.05, * * ; \mathrm{p}<0.01)$. Also shown are the direction of the effects $(-)$ or $(+)$. 
Chapter 3

\subsubsection{Species richness}

Due to the high recruitment rates, especially in 2012-2013, species richness increased in all treatments (Fig 3). Mean species numbers tended to the lower in all nutrient addition treatments than in the control for the three consecutive years, this difference was significant only in the $\mathrm{N}$ treatment in 2013.

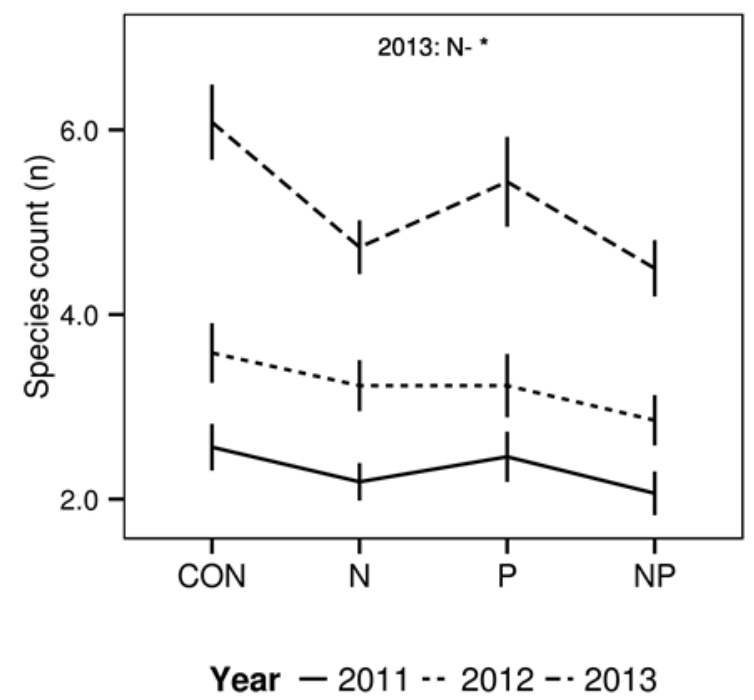

Figure 3.3 Effect of moderate nutrient addition on the species richness according to the seedling community (mean $\pm \mathrm{SE}$ ). Significance in all groups is indicated per year after a two-way ANOVA with $\mathrm{N}$ and $\mathrm{P}$ as explanatory variables. Asterisks shows significant differences (*; $\mathrm{p}<0.05, * * ; \mathrm{p}<0.01)$. Also shown are the direction of the effects (-) or (+).

\subsection{Discussion}

Results from earlier nutrient addition experiments in tropical montane forests suggest that both $\mathrm{N}$ and $\mathrm{P}$ may be limiting tree growth and forest productivity and that in most cases N seems to improve growth conditions for montane forest trees (Tanner et al., 1990; 1992; 1998; Cavelier et al., 2000; Wolf et al., 2011). From the research conducted in NUMEX we know that the soil compartment does react to $\mathrm{N}$ and $\mathrm{P}$ addition with significant alterations of the soil community composition, nutrient fluxes and trace gas emissions (Wullaert et al., 2010; Homeier et al., 2012; Martinson et al., 2013; Camenzind et al., 2014; Krashevska et al., 2014). In addition, the $\mathrm{N}$ cycling in the forest canopy was affected (Matson et al., 2015). The study site is probably co-limited by $\mathrm{N}$ and P (Werner \& Homeier, 2015) as has been reported 
from other tropical forests (e.g., Holste et al., 2011; Santiago et al., 2012). This is supported by the fact that in some parameters, effects were already visible after the first year of nutrient addition (Wullaert et al., 2010; Homeier et al., 2012). Therefore, we expected strong effects on the composition and performance of the seedling community after three to five years of continued nutrient addition.

\subsubsection{Seedling community dynamics}

A strong inter-annual variation in tree seedling density is a typical characteristic of tropical natural forests and is mainly determined by high variability in recruitment rates (e.g., Wright et al., 2005; Metz et al., 2008). Recruitment rates depend on the climatic conditions of the previous years since the underlying processes such as: pollination, seed production, seed germination and seedling establishment in most species are highly dependent on favorable weather conditions (e.g., Bendix et al., 2006).

In spite of the high variation in both seedling density and recruitment rates that could mask effects of nutrient addition, we recorded negative effects of $\mathrm{N}$ addition. Interestingly, there was a difference between the reactions of common and rare species. In the first group, survival was reduced, whereas the latter showed reduced recruitment rates.

We had expected higher seedling densities after nutrient addition that in turn could result in increased (density-dependent) mortality as shown in other studies (Clark \& Clark, 1985; Metz et al., 2012; Webb \& Peart, 2000; Harms et al., 2000; Hille Ris Lambers et al., 2002). However, contrary to our expectations, the $\mathrm{N}$ and the $\mathrm{P}$ treatment, where the negative effect on the survival of common species occurred, had similar or even lower seedling densities than the control. Therefore, low seedling survival must be caused by other factors such as altered herbivory rates (Eichhorn et al., 2010) or competition with adult trees which are reducing the competitive strength of the seedlings of the common species. This result differs from the higher seedling survival rates after $\mathrm{N}$ and $\mathrm{N}+\mathrm{P}$ addition reported by AlvarezClare et al. (2013) for a Costa Rican lowland forest. On the other hand, the negative effects of $\mathrm{N}$ or $\mathrm{P}$ addition on recruitment showed that soil nutrients are possibly not a major limiting factor for the establishment of rare species. 


\subsubsection{Height growth, leaf production and herbivory}

Although we did not measure elevated growth rates, the seedlings when averaged at the community level, and the seedlings of the rare species were on average taller in the $\mathrm{N}$ treatment; this positive $\mathrm{N}$ effect was not found in the common species. The higher values for seedling height at the community level and for the rare species could be partly due to the lower recruitment rates in these groups after $\mathrm{N}$ addition, which reduced the number of newly established and smaller individuals.

In contrast to our study, in two Neotropical lowland forests on relatively fertile soils, seedlings and saplings grew faster after nutrient addition: the adding of $\mathrm{P}$ increased the percentage of growing seedlings in the Costa Rican forest studied by Alvarez-Clare et al. (2013) and the addition of $\mathrm{N}$ and $\mathrm{K}$ increased the growth rates of saplings at Barro Colorado Island, where P had no effect (Wright et al., 2011). Holste et al. (2011) reported that at La Selva lowland forest in Costa Rica, soil nutrients (in the order base cations, nitrogen, and phosphorus) were good predictors of seedling growth in most species.

As opposed to Alvarez-Clare et al. (2013) who found that $\mathrm{P}$ addition resulted in a higher percentage of seedlings that increased leaf number, at our study site there was a negative effect of $\mathrm{P}$ on leaf production of the seedlings of common species and a trend of increased leaf production after $\mathrm{N}$ addition for all species groups.

In contrast with studies from lowland forests, where $\mathrm{P}$ and $\mathrm{K}$ addition increased the level of seedling leaf damage by herbivores (Santiago et al., 2012: BCI, Panama) or no effects were observed after addition of a complete fertilizer $(\mathrm{N}+\mathrm{P}+\mathrm{K}+\mathrm{Mg})$ on seedling herbivory (Eichhorn et al., 2006: Sepilok, Sabah), we found that N addition increased leaf area loss in the studied montane forest. Increased soil nutrient availability probably resulted in higher foliar nutrient concentrations in most species (this was confirmed for foliar $\mathrm{N}$ concentrations in seedlings of the common species Graffenrieda emarginata and Palicourea angustifolia from the NUMEX plots; Cárate et al. in prep.) and thereby made leaves more attractive for herbivores. Folivory rates of adult trees at the study site were found to be highly correlated with both leaf $\mathrm{N}$ and leaf P concentrations (Werner \& Homeier, 2015).

Herbivory plays an essential role in the nutrient cycling of tropical forests and shifts in herbivore abundance or activity caused by environmental change can have strong impacts 
on soil fertility, ecosystem carbon storage and plant species composition (Metcalfe et al., 2014; Werner \& Homeier, 2015).

Since there is a trade-off between seedling growth, survival and herbivory (e.g., Goodale et al., 2014; Norghauer \& Newberry, 2014), herbivory rates may be an important factor influencing niche differentiation among coexisting species in the study area as was shown for other tropical forests (Fine et al., 2004; Eichhorn et al., 2006; Andersen et al., 2010). On the other hand, enhanced herbivory after nutrient addition could mask positive seedling growth responses to elevated nutrient supply as suggest by Andersen et al. (2010) and Santiago et al. (2012).

\subsubsection{Seedling species richness}

Variation in seedling species richness in our study depended on recruitment dynamics and a negative effect of $\mathrm{N}$ addition became visible in the last study year (after five years of continued nutrient addition). A similar negative effect of $\mathrm{N}$ on plant diversity was found by Lu et al. (2010) after long-term addition of high levels of $\mathrm{N}\left(150 \mathrm{~kg} \mathrm{ha}^{-1} \mathrm{yr}^{-1}\right)$ to an oldgrowth tropical forest in China and attributed to N-mediated changes in soil chemistry such as lowered $\mathrm{pH}$, increased $\mathrm{Al}$ mobility, leaching of cations.

\subsection{Conclusions}

The effects found in the studied seedling community of a mountain forest were not as strong as expected and partly contrary to those reported from lowland forests. This deviating response likely indicates the more important role played by $\mathrm{N}$ shortage in montane forests compared to tropical lowlands (Tanner et al., 1998).

Although there is lot of evidence that seedling dynamics of tropical lowland forests is density-dependent, we did not find evidence that seedling density is a strong driver of mortality in the studied montane forest.

The locally common species did not take advantage of the changed nutrient conditions; they seem to be well adapted to the relatively nutrient poor soils but not able to adjust their growth and leaf properties to increased nutrient availability. This suggests that in 
Chapter 3

the long-term, currently common species are going to lose their dominance and most likely be replaced by invading species with faster growth. But since those species first have to reach the study plots with their propagules and then have to establish, it may need a longer period of continued nutrient addition to produce visible shifts in the seedling community composition.

Species-specific responses are hard to recognize in species rich communities where even common species are only present with a few individuals. Therefore, experimental approaches, such as the transplanting of same-aged seedlings to fertilized forest stands, may offer a better way to demonstrate reactions of single species to changes in nutrient availability (e.g., Dent \& Burslem, 2009; Eichhorn et al., 2010).

\subsection{Supplementary information}


TableS3.1 Species and morphospecies of woody plant seedlings registered from 2010-2013 in the NUMEX regeneration plots in the San Francisco Reserve.

\begin{tabular}{|c|c|c|c|}
\hline Family & Genus & Species & Individuals \\
\hline Annonaceae & Guatteria & glauca & 20 \\
\hline Apocynaceae & Indet & sp1 & 2 \\
\hline Aquifoliaceae & Ilex & hippocrateoides & 3 \\
\hline Araliaceae & Schefflera & sp1 & 20 \\
\hline Asteraceae & Indet & sp1 & 4 \\
\hline Asteraceae & Indet & $\mathrm{sp} 3$ & 18 \\
\hline Asteraceae & Indet & sp4 & 29 \\
\hline Asteraceae & Indet & $\mathrm{sp} 5$ & 2 \\
\hline Asteraceae & Indet & sp6 & 1 \\
\hline Asteraceae & Indet & $\mathrm{sp} 2$ & 5 \\
\hline Chloranthaceae & Hedyosmuт & sp1 & 8 \\
\hline Chloranthaceae & Hedyosmuт & $\mathrm{sp} 2$ & 5 \\
\hline Clethraceae & Purdieae & nutans & 13 \\
\hline Clusiaceae & Clusia & sp1 & 74 \\
\hline Clusiaceae & Indet & sp1 & 2 \\
\hline Clusiaceae & Tovomita & weddelliana & 16 \\
\hline Cunnonaceae & Indet & $\mathrm{sp} 1$ & 1 \\
\hline Cunnonaceae & Indet & $\mathrm{sp} 2$ & 2 \\
\hline Elaeocarpaceae & Sloanea & sp1 & 1 \\
\hline Ericaceae & Indet & sp1 & 1 \\
\hline Euphorbiaceae & Alchornea & lojaensis & 12 \\
\hline Euphorbiaceae & Alchornea & sp1 & 5 \\
\hline Euphorbiaceae & Alchornea & triplinervia & 1 \\
\hline Euphorbiaceae & Hieronyma & moritziana & 68 \\
\hline Euphorbiaceae & Indet & sp1 & 15 \\
\hline Indeterminated & Indet & $\operatorname{sp} 1^{\gamma}$ & 5 \\
\hline Indeterminated & Non-identified $^{\delta}$ & & 39 \\
\hline Lauraceae & Aniba & sp1 & 4 \\
\hline Lauraceae & Endlicheria & oreocola & 5 \\
\hline Lauraceae & Indet & sp1 & 9 \\
\hline Lauraceae & Indet & sp1 & 2 \\
\hline Lauraceae & Ocotea & aciphylla & 1 \\
\hline Lauraceae & Ocotea & sp1 & 3 \\
\hline Lauraceae & Persea & weberbaueri & 1 \\
\hline Lecytidaceae & Eschweilera & sp1 & 1 \\
\hline Melastomataceae & Graffenrieda & emarginata & 84 \\
\hline Melastomataceae & Graffenrieda & penneysii & 19 \\
\hline Melastomataceae & Indet & sp1 & 2 \\
\hline Melastomataceae & Indet & $\mathrm{sp} 2$ & 11 \\
\hline Melastomataceae & Miconia & asperrima & 32 \\
\hline Melastomataceae & Miconia & calophylla & 7 \\
\hline Melastomataceae & Miconia & punctata & 11 \\
\hline
\end{tabular}




\section{Chapter 3}

\begin{tabular}{|c|c|c|c|}
\hline Melastomataceae & Miconia & radula & 54 \\
\hline Melastomataceae & Miconia & $\mathrm{sp} 2$ & 11 \\
\hline Melastomataceae & Miconia & sp3 & 12 \\
\hline Melastomataceae & Miconia & sp4 & 36 \\
\hline Melastomataceae & Miconia & sp5 & 10 \\
\hline Melastomataceae & Miconia & $\mathrm{sp} 1$ & 38 \\
\hline Melastomataceae & Topobea & bullata & 1 \\
\hline Mimosaceae & Abarema & killippii & 6 \\
\hline Monimiaceae & Mollinedia & sp1 & 1 \\
\hline Myricaceae & Myrica & pubescens & 1 \\
\hline Myrsinaceae & Indet & sp1 & 11 \\
\hline Myrsinaceae & Myrsine & coriaceae & 2 \\
\hline Myrtaceae & Calyptranthes & concinna & 2 \\
\hline Myrtaceae & Calyptranthes & sp1 & 1 \\
\hline Myrtaceae & Eugenia & $\mathrm{sp} 1$ & 14 \\
\hline Myrtaceae & Indet & sp1 & 6 \\
\hline Myrtaceae & Myrcia & sp. nov. & 666 \\
\hline Myrtaceae & Myrcia & sp1 & 3 \\
\hline Piperaceae & Piper & sp1 & 13 \\
\hline Piperaceae & Piper & $\mathrm{sp} 2$ & 6 \\
\hline Piperaceae & Piper & sp3 & 1 \\
\hline Podocarpaceae & Podocarpus & oleifolius & 1 \\
\hline Polygalaceae & Monnina & sp1 & 1 \\
\hline Proteaceae & Panopsis & sp1 & 11 \\
\hline Rosaceae & Prunus & sp1 & 464 \\
\hline Rubiaceae & Elaeagia & pastoensis & 23 \\
\hline Rubiaceae & Faramea & glandulosa & 11 \\
\hline Rubiaceae & Faramea & sp1 & 2 \\
\hline Rubiaceae & Faramea & $\mathrm{sp} 2$ & 6 \\
\hline Rubiaceae & Faramea & uniflora & 134 \\
\hline Rubiaceae & Indet & sp1 & 4 \\
\hline Rubiaceae & Indet & $\mathrm{sp} 2$ & 17 \\
\hline Rubiaceae & Indet & sp3 & 2 \\
\hline Rubiaceae & Palicourea & andina & 8 \\
\hline Rubiaceae & Palicourea & angustifolia & 146 \\
\hline Rubiaceae & Palicourea & luteonivea & 114 \\
\hline Rubiaceae & Psychotria & subtomentosa & 25 \\
\hline Rubiaceae & Pyschotria & reticulata & 2 \\
\hline Rubiaceae & Stilpnophyllum & oellgaardii & 66 \\
\hline Sapindaceae & Matayba & inelegans & 5 \\
\hline Symplocaceae & Indet & $\mathrm{sp} 1$ & 1 \\
\hline Theaceae & Gordonia & sp1 & 2 \\
\hline
\end{tabular}

Notes: $\gamma$ Groups of individuals with similar features but without an identification neither of genus nor of family. ${ }^{\delta}$ Unidentified species include individuals unique individuals whose characteristics could not be recognized or classified as a morphospecies. 
TableS3.2 Results of the models fit with $n \operatorname{lme}:: \operatorname{lm} e()$. Details of the linear mixed effects models fitted with R package nlme. Significant parameters are highlighted with $* \mathrm{p}<0.05$ or $* * \mathrm{p}<0.01$, marginally significant parameters in (.). Significances are based on conditional t-tests. All models were fit with a full model including $\mathrm{N}$ and $\mathrm{P}$ addition and its interaction, and then subjected to a stepwise selection by AIC, and thus in some cases may contain insignificant terms. Variance covariates were calculated with varPower (power law function of the number of observations) or with varExp (exponential function of the number of observations).

\begin{tabular}{|c|c|c|c|c|c|c|c|c|c|c|}
\hline Subset & Variable & Year & Trans. & $\begin{array}{c}\text { Separate } \\
\text { var. } \\
\text { per block }\end{array}$ & Variance covariate & $\begin{array}{l}\text { Intercept } \\
\text { Estimate }\end{array}$ & $\begin{array}{c}\text { Standard } \\
\text { Error }\end{array}$ & DF & t-Statistic & p-Value \\
\hline All & Height & 2011 & $\log (x)$ & 0 & $\operatorname{varPower}($ form $=\sim \mathrm{n})$ & 2.545 & 0.048 & 149 & 52.675 & $0.000 * * *$ \\
\hline All & Height & 2012 & $\log (x)$ & 1 & $\operatorname{varExp}($ form $=\sim n)$ & 2.400 & 0.050 & 165 & 47.608 & $0.000 * * *$ \\
\hline All & Height & 2013 & $\log (x)$ & 0 & $\operatorname{varPower}($ form $=\sim n)$ & 2.192 & 0.034 & 174 & 65.162 & $0.000 * * *$ \\
\hline All & Herbivory & 2012 & $\operatorname{logit}(\mathrm{x})$ & 0 & varPower(form= n) & -3.002 & 0.058 & 165 & -51.938 & $0.000 * * *$ \\
\hline All & Herbivory & 2013 & $\operatorname{logit}(x)$ & 1 & varPower(form= n) & -3.254 & 0.062 & 173 & -52.734 & $0.000 * * *$ \\
\hline All & $\mathrm{RGRh}$ & 2012 & & 0 & varPower(form= n) & 0.078 & 0.011 & 143 & 6.882 & $0.000 * * *$ \\
\hline All & RGRh & 2013 & & 1 & varPower(form= n) & 0.228 & 0.021 & 151 & 10.780 & $0.000 * * *$ \\
\hline All & RGRl & 2012 & & 1 & $\operatorname{varPower}($ form $=\sim \mathrm{n})$ & 0.134 & 0.044 & 141 & 3.065 & $0.003 * *$ \\
\hline All & RGRl & 2013 & & 1 & $\operatorname{var} \operatorname{Exp}($ form $=\sim \mathrm{n})$ & 0.094 & 0.026 & 148 & 3.634 & $0.000 * * *$ \\
\hline Common & Height & 2011 & $\log (\mathrm{x})$ & 0 & $\operatorname{varPower}($ form $=\sim n)$ & 2.428 & 0.078 & 95 & 31.220 & $0.000 * * *$ \\
\hline Common & Height & 2012 & $\log (x)$ & 0 & $\operatorname{var} \operatorname{Exp}($ form $=\sim \mathrm{n})$ & 2.357 & 0.075 & 127 & 31.456 & $0.000 * * *$ \\
\hline Common & Height & 2013 & $\log (x)$ & 1 & $\operatorname{varPower}($ form $=\sim \mathrm{n})$ & 2.104 & 0.025 & 168 & 83.064 & $0.000 * * *$ \\
\hline Common & Herbivory & 2012 & $\operatorname{logit}(x)$ & 1 & varPower(form= n) & -2.913 & 0.100 & 127 & -29.097 & $0.000 * * *$ \\
\hline Common & Herbivory & 2013 & $\operatorname{logit}(x)$ & 1 & varPower(form= n) & -3.301 & 0.056 & 169 & -58.936 & $0.000 * * *$ \\
\hline Common & $\mathrm{RGRh}$ & 2012 & & 0 & $\operatorname{varPower}($ form $=\sim \mathrm{n})$ & 0.073 & 0.014 & 84 & 5.331 & $0.000 * * *$ \\
\hline Common & RGRh & 2013 & & 0 & $\operatorname{varPower}($ form $=\sim \mathrm{n})$ & 0.232 & 0.026 & 106 & 8.950 & $0.000 * * *$ \\
\hline Common & RGR1 & 2012 & & 0 & $\operatorname{varExp}($ form $=\sim n)$ & 0.133 & 0.054 & 84 & 2.440 & $0.017 * *$ \\
\hline Common & RGRl & 2013 & & 1 & $\operatorname{var} \operatorname{Exp}($ form $=\sim n)$ & 0.138 & 0.032 & 105 & 4.341 & $0.000 * * *$ \\
\hline Rare & Height & 2011 & $\log (\mathrm{x})$ & 0 & varPower(form= n) & 2.657 & 0.064 & 125 & 41.201 & $0.000 * * *$ \\
\hline Rare & Height & 2012 & $\log (x)$ & 0 & $\operatorname{varExp}($ form $=\sim n)$ & 2.506 & 0.073 & 142 & 34.133 & $0.000 * * *$ \\
\hline Rare & Height & 2013 & $\log (x)$ & 0 & $\operatorname{varPower}($ form= n) & 2.284 & 0.091 & 155 & 25.014 & $0.000 * * *$ \\
\hline Rare & Herbivory & 2012 & $\operatorname{logit}(x)$ & 0 & $\operatorname{varPower}($ form $=\sim \mathrm{n})$ & -2.912 & 0.045 & 142 & -64.113 & $0.000 * * *$ \\
\hline Rare & Herbivory & 2013 & $\operatorname{logit}(x)$ & 1 & $\operatorname{varPower}($ form $=\sim n)$ & -3.152 & 0.088 & 155 & -35.789 & $0.000 * * *$ \\
\hline Rare & $\mathrm{RGRh}$ & 2012 & & 0 & $\operatorname{varPower}($ form $=\sim \mathrm{n})$ & 0.088 & 0.013 & 114 & 6.537 & $0.000 * * *$ \\
\hline Rare & RGRh & 2013 & & 0 & $\operatorname{varExp}($ form $=\sim n)$ & 0.113 & 0.022 & 129 & 5.076 & $0.000 * * *$ \\
\hline Rare & RGRl & 2012 & & 1 & $\operatorname{varPower}($ form $=\sim \mathrm{n})$ & 0.029 & 0.081 & 112 & 0.357 & 0.722 \\
\hline
\end{tabular}


Chapter 3

Table S3.2 (Continued)

\begin{tabular}{|c|c|c|c|c|c|c|c|c|c|c|c|c|c|c|c|c|c|}
\hline & & & & & $\mathbf{N}$ & & & & & $\mathbf{P}$ & & & & & $\mathrm{N}:$ & & \\
\hline Subset & Variable & Year & Est. & $S E$ & $D F$ & t-Stats & p-Value & Est. & $S E$ & $D F$ & $t$-Stats & p-Value & Est. & $S E$ & $D F$ & t-Stats & p-Value \\
\hline All & Height & 2011 & 0.200 & 0.070 & 11 & 2.862 & $0.015^{*}$ & & & & & & & & & & \\
\hline All & Height & 2012 & 0.154 & 0.074 & 11 & 2.086 & 0.061 & & & & & & & & & & \\
\hline All & Height & 2013 & 0.145 & 0.047 & 11 & 3.115 & $0.010^{*}$ & & & & & & & & & & \\
\hline All & Herbv. & 2012 & 0.198 & 0.077 & 11 & 2.576 & $0.026^{*}$ & & & & & & & & & & \\
\hline All & Herbv. & 2013 & 0.182 & 0.069 & 11 & 2.657 & $0.022 *$ & & & & & & & & & & \\
\hline All & RGRh & 2012 & & & & & & & & & & & & & & & \\
\hline All & RGRh & 2013 & & & & & & & & & & & & & & & \\
\hline All & RGRl & 2012 & & & & & & -0.088 & 0.062 & 11 & -1.408 & 0.187 & & & & & \\
\hline All & RGRl & 2013 & & & & & & & & & & & & & & & \\
\hline Common & Height & 2011 & 0.014 & 0.121 & 9 & 0.113 & 0.912 & -0.131 & 0.111 & 9 & -1.179 & 0.269 & 0.274 & 0.171 & 9 & 1.603 & 0.143 \\
\hline Common & Height & 2012 & -0.092 & 0.102 & 9 & -0.910 & 0.387 & -0.204 & 0.077 & 9 & -2.642 & $0.027 *$ & 0.342 & 0.139 & 9 & 2.463 & $0.036^{*}$ \\
\hline Common & Height & 2013 & 0.067 & 0.032 & 11 & 2.059 & 0.064 & & & & & & & & & & \\
\hline Common & Herbv. & 2012 & 0.260 & 0.124 & 10 & 2.105 & 0.062 . & -0.245 & 0.122 & 10 & -2.005 & 0.073 . & & & & & \\
\hline Common & Herbv. & 2013 & 0.158 & 0.081 & 11 & 1.951 & 0.077 & & & & & & & & & & \\
\hline Common & RGRh & 2012 & & & & & & & & & & & & & & & \\
\hline Common & RGRh & 2013 & 0.053 & 0.033 & 10 & 1.621 & 0.136 & -0.046 & 0.032 & 10 & -1.432 & 0.183 & & & & & \\
\hline Common & RGRl & 2012 & & & & & & -0.146 & 0.057 & 11 & -2.587 & $0.025^{*}$ & & & & & \\
\hline Common & RGR1 & 2013 & -0.022 & 0.055 & 9 & -0.394 & 0.702 & 0.010 & 0.032 & 9 & 0.317 & 0.759 & -0.157 & 0.082 & 9 & -1.908 & 0.089 . \\
\hline Rare & Height & 2011 & 0.246 & 0.090 & 11 & 2.726 & $0.020^{*}$ & & & & & & & & & & \\
\hline Rare & Height & 2012 & 0.192 & 0.101 & 11 & 1.897 & 0.084 & & & & & & & & & & \\
\hline Rare & Height & 2013 & 0.362 & 0.090 & 10 & 4.026 & $0.002 *$ & 0.137 & 0.089 & 10 & 1.538 & 0.155 & & & & & \\
\hline Rare & Herbv. & 2012 & & & & & & & & & & & & & & & \\
\hline Rare & Herbv. & 2013 & 0.201 & 0.068 & 11 & 2.944 & $0.013^{*}$ & & & & & & & & & & \\
\hline Rare & RGRh & 2012 & & & & & & & & & & & & & & & \\
\hline Rare & RGRh & 2013 & & & & & & & & & & & & & & & \\
\hline Rare & RGRl & 2012 & 0.205 & 0.113 & 9 & 1.812 & 0.103 & 0.068 & 0.117 & 9 & 0.586 & 0.572 & -0.240 & 0.163 & 9 & -1.472 & 0.175 \\
\hline
\end{tabular}


TableS3.3 Results of the models fit with glmmADMB::: glmmadmb(). Details of the linear mixed effects models fitted with R package glmmADMB. Significant parameters are highlighted with $* \mathrm{p}<0.05$ or $* * \mathrm{p}<0.01$, marginally significant parameters in (.). Significances are based on Wald z-tests. All models were fit with a full model including $\mathrm{N}$ and $\mathrm{P}$ addition and its interaction, and then subjected to a stepwise simplification procedure based on AIC. This table shows the results of the final models favored by AIC, and thus in some cases may contain insignificant terms.

\begin{tabular}{|c|c|c|c|c|c|c|c|c|}
\hline Subset & Variable & Year & Distribution & Zero inflation & $\begin{array}{l}\text { Intercept } \\
\text { Estimate }\end{array}$ & Standard Error & z-Statistic & p-Value \\
\hline All & Density & 2011 & negative binomial & 0 & 1.081 & 0.115 & 9.389 & $0.000 * * *$ \\
\hline All & Density & 2012 & negative binomial & 0 & 1.363 & 0.071 & 19.110 & $0.000 * * *$ \\
\hline All & Density & 2013 & negative binomial & 0 & 2.324 & 0.158 & 14.699 & $0.000 * * *$ \\
\hline All & Recruitment & 2012 & negative binomial & 0 & 0.510 & 0.092 & 5.537 & $0.000 * * *$ \\
\hline All & Recruitment & 2013 & negative binomial & 0 & 2.244 & 0.220 & 10.178 & $0.000 * * *$ \\
\hline All & Survival & 2012 & binomial & 0 & 1.494 & 0.158 & 9.479 & $0.000 * * *$ \\
\hline All & Survival & 2013 & binomial & 0 & 1.387 & 0.103 & 13.444 & $0.000 * * *$ \\
\hline All & Spec. count & 2011 & poisson & 0 & 0.906 & 0.101 & 8.961 & $0.000 * * *$ \\
\hline All & Spec. count & 2012 & poisson & 0 & 1.123 & 0.083 & 13.565 & $0.000 * * *$ \\
\hline All & Spec. count & 2013 & poisson & 0 & 1.719 & 0.105 & 16.413 & $0.000 * * *$ \\
\hline Common & Density & 2011 & negative binomial & 0 & 0.295 & 0.117 & 2.513 & $0.012 *$ \\
\hline Common & Density & 2012 & negative binomial & 0 & 0.602 & 0.095 & 6.337 & $0.000 * * *$ \\
\hline Common & Density & 2013 & negative binomial & 0 & 1.959 & 0.129 & 15.162 & $0.000 * * *$ \\
\hline Common & Recruitment & 2012 & negative binomial & 0 & -0.195 & 0.147 & -1.325 & 0.185 \\
\hline Common & Recruitment & 2013 & negative binomial & 0 & 1.729 & 0.178 & 9.702 & $0.000 * * *$ \\
\hline Common & Survival & 2012 & binomial & 0 & 1.518 & 0.179 & 8.484 & $0.000 * * *$ \\
\hline Common & Survival & 2013 & binomial & 0 & 1.744 & 0.244 & 7.158 & $0.000 * * *$ \\
\hline Rare & Density & 2011 & poisson & 0 & 0.488 & 0.110 & 4.453 & $0.000 * * *$ \\
\hline Rare & Density & 2012 & negative binomial & 0 & 0.842 & 0.102 & 8.285 & $0.000 * * *$ \\
\hline Rare & Density & 2013 & negative binomial & 0 & 1.343 & 0.182 & 7.387 & $0.000 * * *$ \\
\hline Rare & Recruitment & 2012 & negative binomial & 0 & -0.159 & 0.205 & -0.773 & 0.439 \\
\hline Rare & Recruitment & 2013 & negative binomial & 0 & 0.799 & 0.287 & 2.781 & $0.005 * *$ \\
\hline Rare & Survival & 2012 & binomial & 0 & 1.499 & 0.214 & 6.994 & $0.000 * * *$ \\
\hline Rare & Survival & 2013 & binomial & 0 & 1.299 & 0.158 & 8.225 & $0.000 * * *$ \\
\hline
\end{tabular}


Chapter 3

Table S3.3 (Continued)

\begin{tabular}{|c|c|c|c|c|c|c|c|c|c|c|c|c|c|c|}
\hline & & & & & $\mathbf{N}$ & & & & $\mathbf{P}$ & & & & $\mathbf{N}: \mathbf{P}$ & \\
\hline Subset & Variable & Year & Est. & $S E$ & z-Statistic & $p$-Value & Est. & $S E$ & $z$-Statistic & p-Value & Est. & $S E$ & z-Statistic & p-Value \\
\hline All & Density & 2011 & & & & & -0.079 & 0.119 & -0.660 & 0.510 & & & & \\
\hline All & Density & 2012 & & & & & & & & & & & & \\
\hline All & Density & 2013 & & & & & & & & & & & & \\
\hline All & Recruitment & 2012 & & & & & & & & & & & & \\
\hline All & Recruitment & 2013 & -0.446 & 0.173 & -2.581 & $0.010 *$ & -0.313 & 0.172 & -1.821 & 0.069 . & 0.395 & 0.246 & 1.606 & 0.108 \\
\hline All & Survival & 2012 & & & & & & & & & & & & \\
\hline All & Survival & 2013 & & & & & & & & & & & & \\
\hline All & Spec. count & 2011 & -0.164 & 0.102 & -1.618 & 0.106 & & & & & & & & \\
\hline All & Spec. count & 2012 & & & & & & & & & & & & \\
\hline All & Spec. count & 2013 & -0.202 & 0.091 & -2.226 & $0.026^{*}$ & & & & & & & & \\
\hline Common & Density & 2011 & -0.374 & 0.167 & -2.241 & $0.025^{*}$ & & & & & & & & \\
\hline Common & Density & 2012 & -0.236 & 0.138 & -1.705 & 0.088 & & & & & & & & \\
\hline Common & Density & 2013 & & & & & & & & & & & & \\
\hline Common & Recruitment & 2012 & & & & & -0.289 & 0.184 & -1.571 & 0.116 & & & & \\
\hline Common & Recruitment & 2013 & & & & & & & & & & & & \\
\hline Common & Survival & 2012 & & & & & & & & & & & & \\
\hline Common & Survival & 2013 & -0.542 & 0.268 & -2.019 & $0.043^{*}$ & -0.450 & 0.270 & -1.668 & 0.095 . & & & & \\
\hline Rare & Density & 2011 & & & & & & & & & & & & \\
\hline Rare & Density & 2012 & & & & & & & & & & & & \\
\hline Rare & Density & 2013 & -0.316 & 0.159 & -1.985 & $0.047 *$ & & & & & & & & \\
\hline Rare & Recruitment & 2012 & & & & & & & & & & & & \\
\hline Rare & Recruitment & 2013 & -0.746 & 0.166 & -4.489 & $0.000 * * *$ & -0.378 & 0.164 & -2.312 & $0.021 *$ & & & & \\
\hline Rare & Survival & 2012 & & & & & & & & & & & & \\
\hline Rare & Survival & 2013 & & & & & 0.359 & 0.241 & 1.490 & 0.136 & & & & \\
\hline
\end{tabular}




\section{Chapter \\ 4}

CONTRASTING SPECIES RESPONSES AMONG TROPICAL MONTANE FOREST TREE SEEDLINGS TO CONTINUED NITROGEN AND PHOSPHORUS ADDITION

With Tessa Camenzind, Christoph Leuschner and Jürgen Homeier 


\subsection{Summary}

With the replicated nutrient manipulation experiment NUMEX, we studied the effects of increased $\mathrm{N}$ and $\mathrm{P}$ availability on the seedlings of six common tree species in montane forests of southern Ecuador. Since earlier studies had produced evidence of $\mathrm{P}$ and $\mathrm{N}$ limitation in our study region, we expected that continued nutrient addition would release tree seedlings from nutrient limitation. We predicted that the seedlings would adjust leaf traits, suffer from increased herbivory, and allocate less carbohydrates to the roots.

After five years of continued N, P or N+P addition, 2-3 year-old seedlings of each two common species at three elevation levels (1000, 2000 and $3000 \mathrm{~m})$ were harvested for studying leaf morphology, nutrient content, herbivory rate, aboveground/belowground biomass allocation and root colonization with arbuscular mycorrhizal fungi (AMF) in response to nutrient addition.

The control plants had foliar N:P ratios > 20 in all plots suggesting growth limitation primarily by $\mathrm{P}$ rather than $\mathrm{N}$. Most species showed increased foliar $\mathrm{N}$ and $\mathrm{P}$ concentrations after addition of the respective element (except for Pouteria torta at $1000 \mathrm{~m}$ with no response). However, increased herbivory was only evident in Graffenrieda emarginata (after $\mathrm{N}$ and $\mathrm{N}+\mathrm{P}$ addition) and Palicourea angustifolia (after P addition) at $2000 \mathrm{~m}$. SLA and leaf area ratio were modified upon nutrient addition only in a minority of species; in particular the species at $3000 \mathrm{~m}$ responded to $\mathrm{N}$ addition (Hedyosmum purpurascens) or $\mathrm{P}$ addition (Graffenrieda harlingii) with higher SLA. Both Graffenrieda species responded to $\mathrm{N}$ and $\mathrm{P}$ addition with increased stem biomass fractions, while the other species showed no systematic effect on biomass allocation. In $G$. harlingii, the root biomass fraction was reduced, while in G. emarginata, the leaf fraction decreased. The infection rate by AMF was reduced upon nutrient addition only in G. emarginata. We conclude that the response of tropical montane forest tree seedlings to continued $\mathrm{N}$ and $\mathrm{P}$ addition is highly species-specific, reflecting different adaptation strategies. The responsiveness varied with elevation and was more pronounced at higher elevations, where the nutrient addition had a stronger effect on nutrient availability.

Key words: AMF, Ecuador, foliar nutrients, NUMEX, nutrient manipulation, root-shoot ratio, SLA, biomass allocation 


\subsection{Introduction}

Human alteration of nutrient availability in most ecosystems on earth is one of the most severe environmental problems of our time. In particular, changes in the availability of phosphorus $(\mathrm{P})$ and nitrogen $(\mathrm{N})$ are supposed to affect ecosystem dynamics in the majority of tropical forests (Tanner et al., 1998; Lewis \& Tanner, 2000; Elser et al., 2007; Vitousek et al., 2010; Harpole et al., 2011; Homeier et al., 2012; Fisher et al., 2013; Peñuelas et al., 2013). Additional $\mathrm{N}$ inputs include $\mathrm{N}$ compounds emitted with farming, livestock breeding, fossil fuel combustion and biomass burning (Galloway et al., 2008; Peñuelas et al., 2013), whereas the only source of atmospheric P deposition are mineral aerosols (Mahowald et al., 2005; 2008; Peñuelas et al., 2013). The deposition of $\mathrm{P}$ is small compared to $\mathrm{N}$ deposition.

Previous studies concluded that tropical lowland forests on old soils are likely to be limited in growth mainly by $\mathrm{P}$, whereas in tropical montane forests on younger soils, plant growth might be primarily limited by low N supply (Tanner et al., 1998; Unger et al., 2010; Vitousek et al., 2010; Wolf et al., 2011; Fisher et al., 2013). Apart from this general elevation-dependent pattern, the combination of specific local conditions (temperature, precipitation, soil type and local biota) should determine if an element becomes limiting for plant growth or not.

Several fertilization experiments in tropical forests that focused on regeneration processes have been conducted to determine how juvenile trees respond to the addition of limiting nutrients in different forest types (Ceccon et al., 2003; Lu et al., 2010; Santiago et al., 2012). According to these studies, seedlings showed varying responses to nutrient addition (Palmiotto et al., 2004; Davitt \& Wright, 2008; Eichhorn et al., 2010; Santiago et al., 2012; Alvarez-Clare et al., 2013). Some studies demonstrated that juvenile trees respond to $\mathrm{N}$ and /or $\mathrm{P}$ addition by increased height growth or the production of additional leaves (Yavitt \& Wright, 2008; Bungard et al., 2000; Zalamea et al., 2016).

Foliar nutrient concentrations after fertilization can represent a suitable means for detecting nutrient limitation of ecosystems (Ostertag \& DiManno, 2016). In earlier studies, tropical tree seedlings were found to respond to an increase of $\mathrm{N}$ and $\mathrm{P}$ availability with higher SLA (e.g., Burslem et al., 1995; Cárate-Tandalla et al., 2015; Wan Juliana et al., 2009), higher foliar nutrient concentrations (e.g., Ostertag \& DiManno, 2016; Palmiotto et 
al., 2004; Santiago et al., 2012), and altered N:P ratios (e.g., Ostertag \& DiManno, 2016; Schreeg et al., 2014). In several fertilization experiments it was shown that the fertilised plants had thinner leaves with higher nutrient content and thus were more attractive to herbivores (e.g., Andersen et al., 2010; Campo \& Dirzo, 2003; Cárate-Tandalla et al., 2015; Santiago et al., 2012). The availability of nutrients is, apart from light, one of the determinants of $\mathrm{C}$ allocation patterns in tree seedlings and increased nutrient availability is expected to result in a higher leaf mass fraction and a reduction of root mass fraction (Paz, 2003; Poorter et al., 2012).

However, few studies have examined in situ, how tropical rain forest tree seedlings perform under experimentally modified $\mathrm{N}$ and $\mathrm{P}$ levels and whether changes in nutrient availability are resulting in morphological adaptations (Kobe, 1999; Baraloto et al., 2006; Dent \& Burslem, 2009; Wan Juliana et al., 2009). For tropical montane forests, knowledge is particularly scarce (Andersen et al., 2010, Cárate-Tandalla et al., 2015).

The ongoing Ecuadorian Nutrient Manipulation EXperiment (NUMEX) was started in 2008 to study if and to what extent $\mathrm{N}$ and $\mathrm{P}$ limitation control tropical montane forest functioning at three elevation levels $(1000 \mathrm{~m}, 2000 \mathrm{~m}$ and $3000 \mathrm{~m})$ with the overarching goal to simulate the effects of future increasing atmospheric nutrient deposition on ecosystem processes (Homeier et al., 2012; 2013).

Along the studied elevation gradient, forest structure and species composition are changing as a result of shifting abiotic and biotic conditions; with increasing elevation temperature decreases, precipitation increases and forest productivity and soil $\mathrm{N}$ mineralization decrease (Leuschner et al., 2007; Bendix et al., 2008; Homeier et al., 2010; Wolf et al., 2011). Leuschner et al. (2007) showed that the root-shoot ratio of the trees strongly increased from 1000 to $3000 \mathrm{~m}$ as a consequence of the less favorable soil conditions at upper elevations, in particular low $\mathrm{N}$ availability. Leaf area loss by herbivory was shown to depend on foliar $\mathrm{N}$ and $\mathrm{P}$ concentrations which in turn reflected soil nutrient availability (Werner \& Homeier, 2015). Average foliar N:P ratios $\geq 22$ measured in the nonfertilized trees at all study sites $(\geq 65$ trees from $\geq 16$ plant families per site, Homeier et al. unpublished) suggest that $\mathrm{P}$ is the prevailing limiting nutrient for plant growth at all elevations in this study region (Townsend et al., 2007). 
Nutrient addition in the NUMEX experiment had already altered several state variables of the ecosystem after the first year and is increasingly affecting biological and biogeochemical processes, which may influence seedling vitality, growth and survival. For common tree species, Homeier et al. (2012) reported a positive growth response after N (two of four studied species), $\mathrm{P}$ (two of four species) and $\mathrm{N}+\mathrm{P}$ addition (three out of four species) and increased foliar $\mathrm{N}$ and $\mathrm{P}$ concentrations in three of the four study species after $\mathrm{N}+\mathrm{P}$ addition suggesting that $\mathrm{N}$ and $\mathrm{P}$ might be co-limiting at $2000 \mathrm{~m}$. At the same site, Camenzind et al. (2014) detected reductions in the abundance and species richness of arbuscular mycorrhizal fungi (AMF) after N and P addition. Krashevska et al. (2013) found that the decomposer system (microorganisms and saprophytic fungi) responded to the nutrient addition, concluding that soil microorganisms were generally limited by $\mathrm{N}$ at all elevations and saprophytic fungi also by P. Moreover, P (but not N) addition increased the amount of water-stable soil macro-aggregates at $1000 \mathrm{~m}$, which play an important role for soil stability and nutrient cycling (Camenzind et al., 2016). Four years of $\mathrm{N}$ and N+P addition (but not of $\mathrm{P}$ addition alone) resulted in increased mineral $\mathrm{N}$ production and decreased microbial $\mathrm{N}$ retention (Baldos et al., 2015). In addition, the topsoil $\mathrm{NO}_{3}$ - concentration was increased in the $\mathrm{N}$ and $\mathrm{N}+\mathrm{P}$ treated plots but reduced when only $\mathrm{P}$ was added (Müller et al., 2015, Table S1). Dietrich et al. (2016) found that $\mathrm{P}$ and $\mathrm{N}+\mathrm{P}$ addition increased the bioavailable inorganic $\mathrm{P}$ concentration and decreased the phosphatase activity in the organic layer (Table S1).

In this study, we aimed to understand the seedling response of several common tree species of this old-growth montane forest to continued $\mathrm{N}$ and $\mathrm{P}$ addition. We were especially interested in adaptive modifications of leaf morphology and chemistry, and altered $\mathrm{C}$ allocation patterns towards roots, whereby nutrient uptake capacity would be increased. Such modifications in response to nutrient addition could give hints on the prevailing growth limitation at different elevations by $\mathrm{N}, \mathrm{P}$ or both elements. With reference to earlier results from the study region and published data from other tropical montane forests, we assumed that the tree seedlings were limited by both $\mathrm{N}$ and $\mathrm{P}$ at the NUMEX control sites, while $\mathrm{N}$ and $\mathrm{P}$ addition should partly release the plants from nutrient limitation. We hypothesized that $\mathrm{N}$ and $\mathrm{P}$ addition would lead (i) to higher SLA, a greater leaf area fraction and increased foliar $\mathrm{N}$ and $\mathrm{P}$ concentrations, ii) to higher herbivory levels due to a herbivore preference for 
Chapter 4

higher-quality food, and iii) to reduced carbohydrate allocation to the root system, a lowered root:shoot ratio, and a reduced mycorrhizal infection rate of the roots.

\subsection{Methods}

\subsubsection{Study sites}

The study was conducted in the tropical montane forests of the southern Andes of Ecuador within Podocarpus National Park (PNP) and the San Francisco Reserve (SFR) east of the city of Loja (Figure 4.S1). Three study sites were selected along an elevation gradient at ca. 1000m a.s.l. (Bombuscaro), ca. 2000 m (San Francisco) and ca. 3000 m (Cajanuma). All study sites comprise evergreen old-growth forest (Homeier et al., 2013) with noticeable differences in climate, soil characteristics and forest structure (Table 4.1, Table 4.S1).

The climate of the study area is tropical humid with a wet season from April to July and a less humid period from September to December (Emck, 2007). Mean annual temperature decreases with elevation at a lapse rate of $\sim 5^{\circ} \mathrm{C} \mathrm{km}^{-1}$ from $19.4{ }^{\circ} \mathrm{C}$ at $1000 \mathrm{~m}$ to $9.4^{\circ} \mathrm{C}$ at $3000 \mathrm{~m}$. Annual precipitation increases from about $2000 \mathrm{~mm}$ at 1000 and $2000 \mathrm{~m}$ to $4500 \mathrm{~mm}$ at $3000 \mathrm{~m}$ (Bendix et al., 2008; Wittich et al., 2015; Wolf et al., 2011).

Soils are Dystric Cambisols at the $1000 \mathrm{~m}$ site, Stagnic Cambisols at $2000 \mathrm{~m}$ and Stagnic Histosols at 3000 m (Wolf et al., 2011; Homeier et al., 2013). The three study sites harbor different forest types. Evergreen premontane rain forest (PMF) that reaches up to $40 \mathrm{~m}$ height occurs at the lowest site. Evergreen lower montane rain forest (LMF) is present at the second site at $2000 \mathrm{~m}$ with a canopy height of 18 to $22 \mathrm{~m}$. Evergreen upper montane rain forest (UMF) with a canopy height rarely exceeding 8 to $10 \mathrm{~m}$ occurs at the highest site (Homeier et al., 2008). At the NUMEX sites, canopy openness increased with elevation from $9.7 \pm 0.3 \%$ (mean \pm SE) at $1000 \mathrm{~m}$ to $9.8 \pm 0.4 \%$ at $2000 \mathrm{~m}$, and to $16.4 \pm 0.9 \%$ at $3000 \mathrm{~m}$. 
Table4.1 Physiogeographic and stand structural characteristics of the three study sites.

\begin{tabular}{|c|c|c|c|}
\hline & $1000 \mathrm{~m}$ & $2000 \mathrm{~m}$ & $3000 \mathrm{~m}$ \\
\hline \multicolumn{4}{|l|}{ Location } \\
\hline Altitudinal range $\mathrm{A}^{\mathrm{A}}$ & 990-1100 m.a.s.1. & 2020-2100 m.a.s.l. & 2900-3020 m.a.s.1. \\
\hline Coordinates $^{\mathrm{A}}$ & $4^{\circ} 7^{\prime} \mathrm{S}, 78^{\circ} 58^{\prime} \mathrm{W}$ & $3^{\circ} 58^{\prime} \mathrm{S}, 79^{\circ} 11^{\prime} \mathrm{W}$ & $4^{\circ} 7^{\prime} \mathrm{S}, 79^{\circ} 11^{\prime} \mathrm{W}$ \\
\hline Temperature $^{\mathrm{B}}$ & $19.4{ }^{\circ} \mathrm{C}$ & $15.7^{\circ} \mathrm{C}$ & $9.4^{\circ} \mathrm{C}$ \\
\hline $\begin{array}{l}\text { Mean } \\
\text { precipitation }^{B}\end{array}$ & $2230 \mathrm{~mm}$ & $1950 \mathrm{~mm}$ & $4500 \mathrm{~mm}$ \\
\hline \multicolumn{4}{|l|}{ Forest Structure } \\
\hline Canopy height ${ }^{\mathrm{A}}$ & $20-25 \mathrm{~m}$ & $10-14 \mathrm{~m}$ & $6-8 \mathrm{~m}$ \\
\hline Tree density ${ }^{\mathrm{A}}$ & 748 trees ha $^{-1}$ & 1143 tree ha $^{-1}$ & 1305 trees $^{-1}$ \\
\hline Basal area ${ }^{\mathrm{A}}$ & $33.4 \mathrm{~m}^{2} \mathrm{ha}^{-1}$ & $22.8 \mathrm{~m}^{2} \mathrm{ha}^{-1}$ & $25.5 \mathrm{~m}^{2} \mathrm{ha}^{-1}$ \\
\hline Vegetation type $\mathrm{A}^{\mathrm{A}}$ & $\begin{array}{c}\text { Evergreen premontane } \\
\text { forest }\end{array}$ & $\begin{array}{l}\text { Evergreen lower } \\
\text { montane forest }\end{array}$ & $\begin{array}{l}\text { Evergreen upper montane } \\
\text { forest }\end{array}$ \\
\hline Soil type $\mathrm{A}^{\mathrm{A}}$ & Dystric Cambisol & Stagnic Cambisol & Stagnic Histosol \\
\hline $\begin{array}{l}\text { Organic layer } \\
\text { depth }^{\mathrm{A}}\end{array}$ & $<1 \mathrm{~cm}$ & $10-30 \mathrm{~cm}$ & $10-40 \mathrm{~cm}$ \\
\hline
\end{tabular}

${ }^{\mathrm{A}}$ (Homeier et al. 2013); ${ }^{\mathrm{B}}$ (Wittich et al. 2015)

\subsubsection{Experiment design}

The Ecuadorian Nutrient Manipulation Experiment has been designed with the aim to examine the effects of moderate nutrient deposition on tropical montane forests at different elevation. Within a full-factorial experimental approach set up at each study site (1000, 2000 and $3000 \mathrm{~m}), 16$ plots of $400 \mathrm{~m}^{2}$ each $(20 \mathrm{~m}$ x $20 \mathrm{~m})$ were established. These accommodate four treatments $(\mathrm{N}, \mathrm{P}, \mathrm{N}+\mathrm{P}$, control) in fourfold replication. Each one replicate plot per treatment was assigned to four different blocks in which they were placed randomly. The plots were installed in old-growth, closed-canopy stands without visible signs of human or natural disturbance and were at least $10 \mathrm{~m}$ distant to each other. $\mathrm{N}$ and $\mathrm{P}$ were added to the plots at an annual rate of $50 \mathrm{~kg} \mathrm{~N} \mathrm{ha}^{-1}$ (as urea, $\mathrm{CH}_{4} \mathrm{~N}_{2} \mathrm{O}$ ) and $10 \mathrm{~kg} \mathrm{P}^{-1}\left(\right.$ as $\mathrm{NaH}_{2} \mathrm{PO}_{4}$ ). The nutrients were dispersed homogeneously within the plots on two application dates per year. NUMEX was started in February 2008 and was in its 5th year in 2013, when this study was conducted.

For this study on seedling responses, individuals of the two most common tree species at each elevation level were collected. We selected Clarisia racemosa (Moraceae) and 
Chapter 4

Pouteria torta (Sapotaceae) at $1000 \mathrm{~m}$, Graffenrieda emarginata (Melastomataceae) and Palicourea angustifolia (Rubiaceae) at $2000 \mathrm{~m}$, and Graffenrieda harlingii (Melastomataceae) and Hedyosmum purpurascens (Chloranthaceae) at $3000 \mathrm{~m}$ which represented the most abundant species in the tree seedling communities at the respective sites (Cárate-Tandalla, unpublished data). We attempted to harvest 20 individual seedlings of each species equally distributed to the four treatment plots, which had an age of ca. 2-3 years and showed variation in terms of height, stem diameter and leaf number depending on species and locality. The age of the seedlings was estimated from seedling monitoring data collected in tree regeneration plots in all NUMEX sites. We omitted plants growing in recent understory gaps. Since the seedling density of the six target species varied considerably in these speciesrich forest stands, we were not able to study 20 seedling individuals in each species and treatment. Details on realized replicate numbers in the different plots and the size of the sampled seedlings are given in Table S2. All species occurred in all plots and treatments with at least one individual, except for Pouteria which occurred only in three of the four $\mathrm{N}$ addition plots at $1000 \mathrm{~m}$.

Immediately before seedling harvest in June 2013, every individual was measured (stem diameter, stem length, number of leaves, length and width of the largest leaf) and photographed. Seedlings were harvested completely and then separated into stem, root and leaf fractions. Fresh leaves were scanned at 150dpi (Canon LIDE 100) and total leaf area and leaf area loss by herbivory were determined with WinFolia 2005b (Régent Intruments Inc., Quebec City, QC, Canada) software. All fractions were dried for two days at $65^{\circ} \mathrm{C}$ and then weighed. We determined specific leaf area (SLA) and leaf area ratio (LAR) i.e., total leaf area per plant per total plant dry mass. Patterns of biomass partitioning were quantified through root:shoot ratio and the root, stem and leaf fractions, which were calculated after Poorter (2000). Additionally, we estimated stem slenderness as the relationship between stem length and basal diameter. The percentage of leaf area lost due to herbivore consumption was optically determined. Dried leaves were sent to the laboratory of the Department of Plant Ecology, Göttingen, and analyzed for foliar $\mathrm{C}, \mathrm{N}$ and $\mathrm{P}$ concentrations using a $\mathrm{C} / \mathrm{N}$ elemental analyzer (Vario EL III, Elementa, Hanau, Germany) and Inductively Coupled Plasma Analysis (Optima 5300DV ICP-OES, Perkin Elmer, Waltham, Massachusetts, USA) in case of total $\mathrm{P}$ after digesting the leaf samples with $\mathrm{HNO}_{3}$. Both foliar $\mathrm{C}: \mathrm{N}$ and $\mathrm{N}: \mathrm{P}$ mass ratios 
were calculated. The dried root material was sent to the laboratory of the Department of Ecology, University of Berlin, Germany, for mycorrhizal analyses.

\subsubsection{Mycorrhizal infection}

The intraradical abundance of mycorrhizal fungi was determined in roots stained with Trypan Blue, according to a modified staining protocol (Phillips \& Hayman, 1970; Camenzind \& Rillig, 2013). Roots were stained with $0.05 \%$ Trypan Blue at $60{ }^{\circ} \mathrm{C}$ after an extended destaining phase with $10 \% \mathrm{KOH}$ at $60^{\circ}$ for 12 hours followed by exposure to $20 \%$ $\mathrm{H}_{2} \mathrm{O}_{2}$ at room temperature for 20-30 min. Exact staining periods depended on the root characteristics of the respective tree species. The percentage of arbuscular mycorrhizal and ectomycorrhizal root colonization was counted at 200x magnification following the lineintersect method of McGonigle et al. (1990). Both Graffenrieda species were found to have AMF as well as ectomycorrhizae. In the case of Pouteria torta, determination of AMF abundance was not possible due to the predominance of a thick taproot and an insufficient amount of fine roots.

\subsubsection{Statistical analyses}

All statistical analyses were done using R 3.1.1 software (R Development Core Team 2014). The seedling attributes mentioned above were evaluated using linear mixed model analysis (LMM). Applying the function "lmer" of the R package "lme4" (Bates et al., 2014), we contrasted the treatments with the control. We included "block" as a random intercept in all cases to consider the potential variability among plots of the same treatment. Comparison of the two fitted models to determine differences between the treatments were made by using a likelihood-ratio test (ANOVA). Predicted values for the fitted model were evaluated by calculating mean values using REML. P-values were estimated with the function "cftest" from the package "multcomp" (Hothorn et al., 2008). To scale the predicted values, we calculated intervals of confidence at $95 \%$ with the function 'confint'. The data were transformed prior to analysis if required for fitting the models. 


\subsection{Results}

The six studied species showed highly species-specific responses to nutrient addition in the morphological traits examined. In general, the seedlings from the two upper sites (2000 $\mathrm{m}$ and $3000 \mathrm{~m}$ ) responded more strongly than those of the two species of the lowermost sites (1000 m, Table 4.2).

Table 4.2 Summary of seedling responses to continued nutrient addition. Symbols represent significant positive (+) or negative (-) effects in one species, or contrasting (+/-) effects in the each two species per elevation. Double symbols indicate that both species responded in the same way.

\begin{tabular}{|c|c|c|c|c|c|c|c|c|c|}
\hline & \multicolumn{3}{|c|}{$1000 \mathrm{~m}$} & \multicolumn{3}{|c|}{$2000 \mathrm{~m}$} & \multicolumn{3}{|c|}{$3000 \mathrm{~m}$} \\
\hline & $\mathrm{N}$ & $\mathrm{P}$ & $\mathrm{N}+\mathrm{P}$ & $\mathrm{N}$ & $\mathrm{P}$ & $\mathrm{N}+\mathrm{P}$ & $\mathrm{N}$ & $\mathrm{P}$ & $\mathrm{N}+\mathrm{P}$ \\
\hline $\operatorname{SLA}\left(\mathrm{cm}^{2} \mathrm{~g}^{-1}\right)$ & & - & + & & & & & + & + \\
\hline $\operatorname{LAR}\left(\mathrm{cm}^{2} \mathrm{~g}^{-1}\right)$ & & - & & & & & + & & + \\
\hline Herbivory (\%) & & & & + & + & + & & & \\
\hline Foliar $\mathrm{N}\left(\mathrm{mg} \mathrm{g}^{-1}\right)$ & & & + & ++ & + & + & + & & ++ \\
\hline Foliar $\mathrm{P}\left(\mathrm{mg} \mathrm{g}^{-1}\right)$ & + & + & $+/-$ & & ++ & + & & ++ & ++ \\
\hline Foliar N:P ratio & - & - & $-/+$ & ++ & - & - & & - & - \\
\hline Leaf fraction & & & & & - & & + & + & + \\
\hline Stem fraction & & $-/+$ & & + & + & + & + & + & \\
\hline Root fraction & & & & & & & + & & \\
\hline Root:shoot ratio & & + & & & & & $+/-$ & - & - \\
\hline AMF colonization (\%) & & & & - & - & -- & - & & \\
\hline
\end{tabular}

\subsubsection{Leaf morphology and herbivory}

The two species at $1000 \mathrm{~m}$ showed contrasting changes in leaf morphology in response to nutrient addition. The leaves of Clarisia in the $\mathrm{N}+\mathrm{P}$ treatment had a higher SLA than the control plants, while the Pouteria seedlings reduced their SLA and LAR compared to the control (Figure 1, Table S3). At $2000 \mathrm{~m}$, the two target species did not adjust their SLA and LAR significantly after nutrient addition. At $3000 \mathrm{~m}$, both species had higher average SLA values in all three nutrient addition treatments; significantly higher values were found for Hedyosmum in the two P treatments (Figure 1, Table S3). G. harlingii increased its LAR in both $\mathrm{N}$ treatments. 
At $1000 \mathrm{~m}$ and $3000 \mathrm{~m}$, we found no significant nutrient addition effects on herbivory rate. However, at $1000 \mathrm{~m}$, P. torta showed a trend toward higher herbivory in response mainly to $\mathrm{P}$ and N+P addition (Figure 2). At 2000 m, G. emarginata showed higher leaf area consumption after $\mathrm{N}$ and $\mathrm{N}+\mathrm{P}$ addition. An opposite response was observed in Palicourea which showed higher leaf area losses in the P treatment.
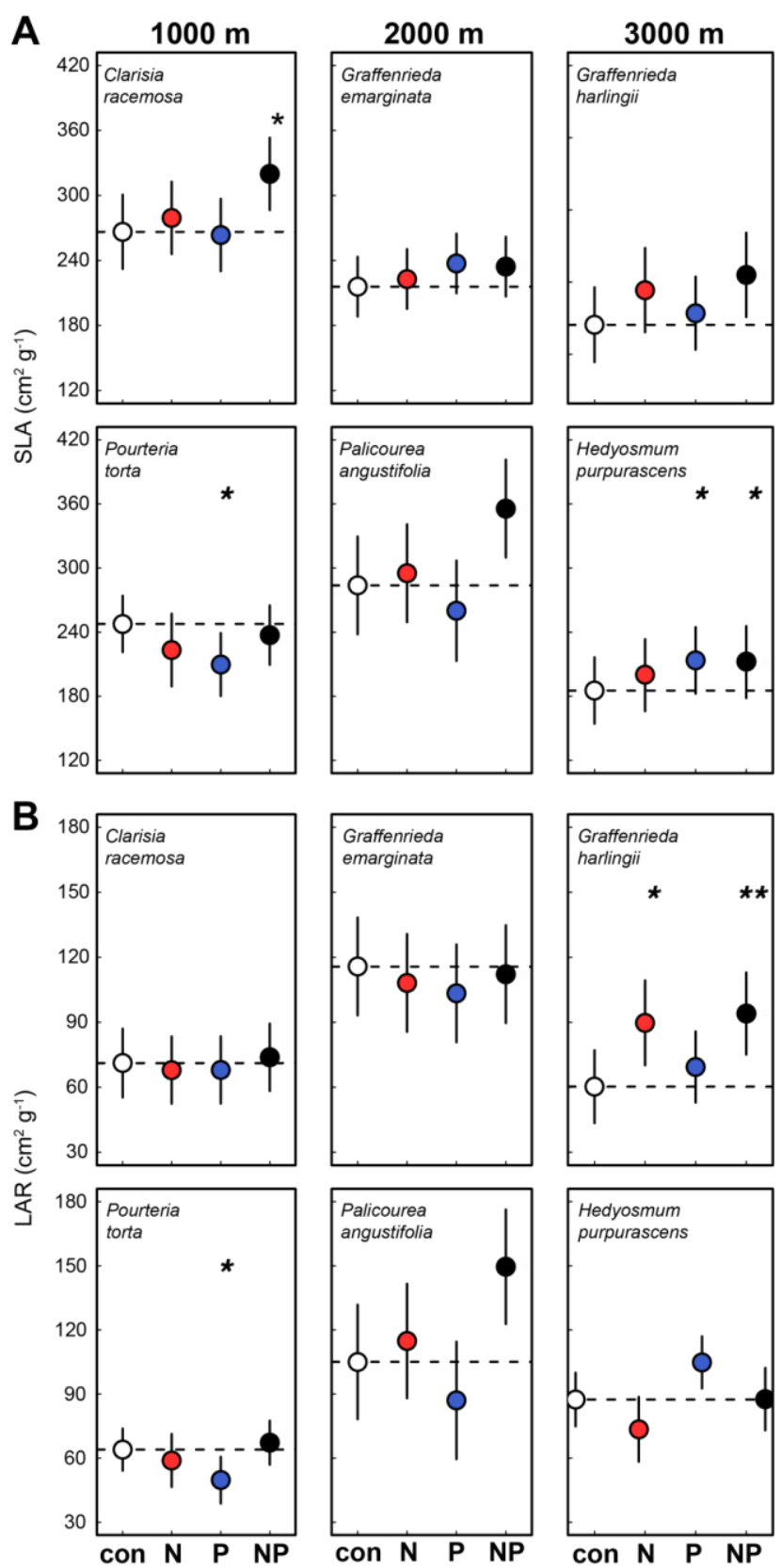

Figure 4.1 Morphological leaf attributes of the seedlings of six common tree species after N (red), P (blue) or combined $\mathrm{N}$ and $\mathrm{P}$ (black) addition. Mean values were obtained from fitted models and scaled to $95 \%$ confidence intervals. A) Specific leaf area (SLA), B) Leaf area ratio (LAR). Significance levels are: $* \mathrm{P}<0.05$, $* * \mathrm{P}<0.01,($.) $\mathrm{P}<0.10$. 

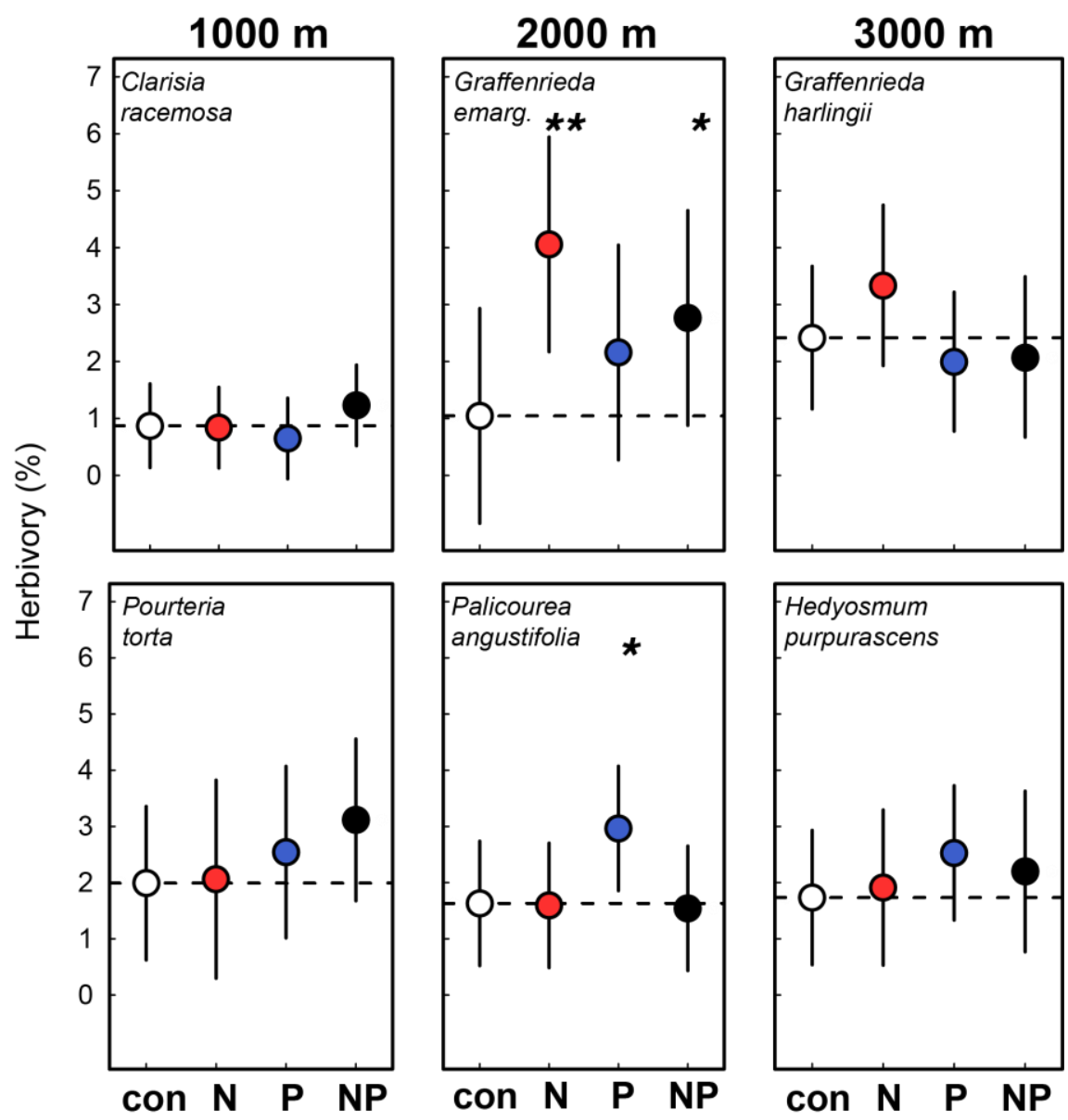

Figure 4.2 Leaf area loss due to herbivory in the seedlings of six common tree species after N (red), P (blue) or combined $\mathrm{N}$ and $\mathrm{P}$ (black) addition. Mean values were obtained from fitted models and scaled to $95 \%$ confidence intervals. Significance levels are: $* \mathrm{P}<0.05, * * \mathrm{P}<0.01$, (.) $\mathrm{P}<0.10$.

\subsubsection{Foliar nutrients}

In the control plots, the Clarisia seedlings had the highest foliar $\mathrm{N}$ concentrations of the six species (mean $=27.3 \mathrm{mg} \mathrm{g}^{-1}$ ), while the two Graffenrieda species showed the lowest means (both $<12 \mathrm{mg} \mathrm{g}^{-1}$ ) (Figure 3, Table S3). All species had at least slightly increased foliar $\mathrm{N}$ concentrations in the $\mathrm{N}$ and $\mathrm{N}+\mathrm{P}$ treatments. Foliar $\mathrm{N}$ was significantly increased in four species in the N+P treatment (Clarisia, G. emarginata, G. harlingii and Hedyosmum), and in three species in the $\mathrm{N}$ treatment (Palicourea, G. emarginata and G. harlingii). 
Among the control plants, the two species from $1000 \mathrm{~m}$ had the highest $\mathrm{P}$ concentrations (Pouteria: $0.92 \mathrm{mg} \mathrm{g}^{-1}$, Clarisia: $1.11 \mathrm{mg} \mathrm{g}^{-1}$ ), while the four species from the 2000 and $3000 \mathrm{~m}$ sites all had lower means in the range of $0.49-0.69 \mathrm{mg} \mathrm{g}^{-1}$ (Figure 3, Table S3). Four species (Clarisia, G. emarginata, G. harlingii and Hedyosmum) showed higher foliar $\mathrm{P}$ concentrations after $\mathrm{P}$ addition ( $\mathrm{P}$ and $\mathrm{N}+\mathrm{P}$ treatment); in Palicourea, foliar $\mathrm{P}$ was increased only in the $\mathrm{P}$ treatment. In contrast to the other species, Pouteria showed reduced foliar $\mathrm{P}$ concentrations in the $\mathrm{N}+\mathrm{P}$ treatment.

All species had foliar N:P ratios > 20; the highest ratio was found in Palicourea (30.4). The two species from $3000 \mathrm{~m}$ had the smallest N:P ratios (G. harlingii: 22.0, Hedyosmum: 21.0) (Figure 4, Table S3). In all species, the N:P ratio was lowered in the P treatment; only in Pouteria, this decrease was not significant. In three species (Clarisia, G. emarginata and Hedyosmum), combined $\mathrm{N}$ and $\mathrm{P}$ addition also resulted in a significantly decreased N:P ratio. In contrast, $\mathrm{N}$ addition increased the N:P ratio of both species at $2000 \mathrm{~m}$ (G. emarginata and Palicourea), while it decreased it in the Clarisia seedlings. 
Chapter 4

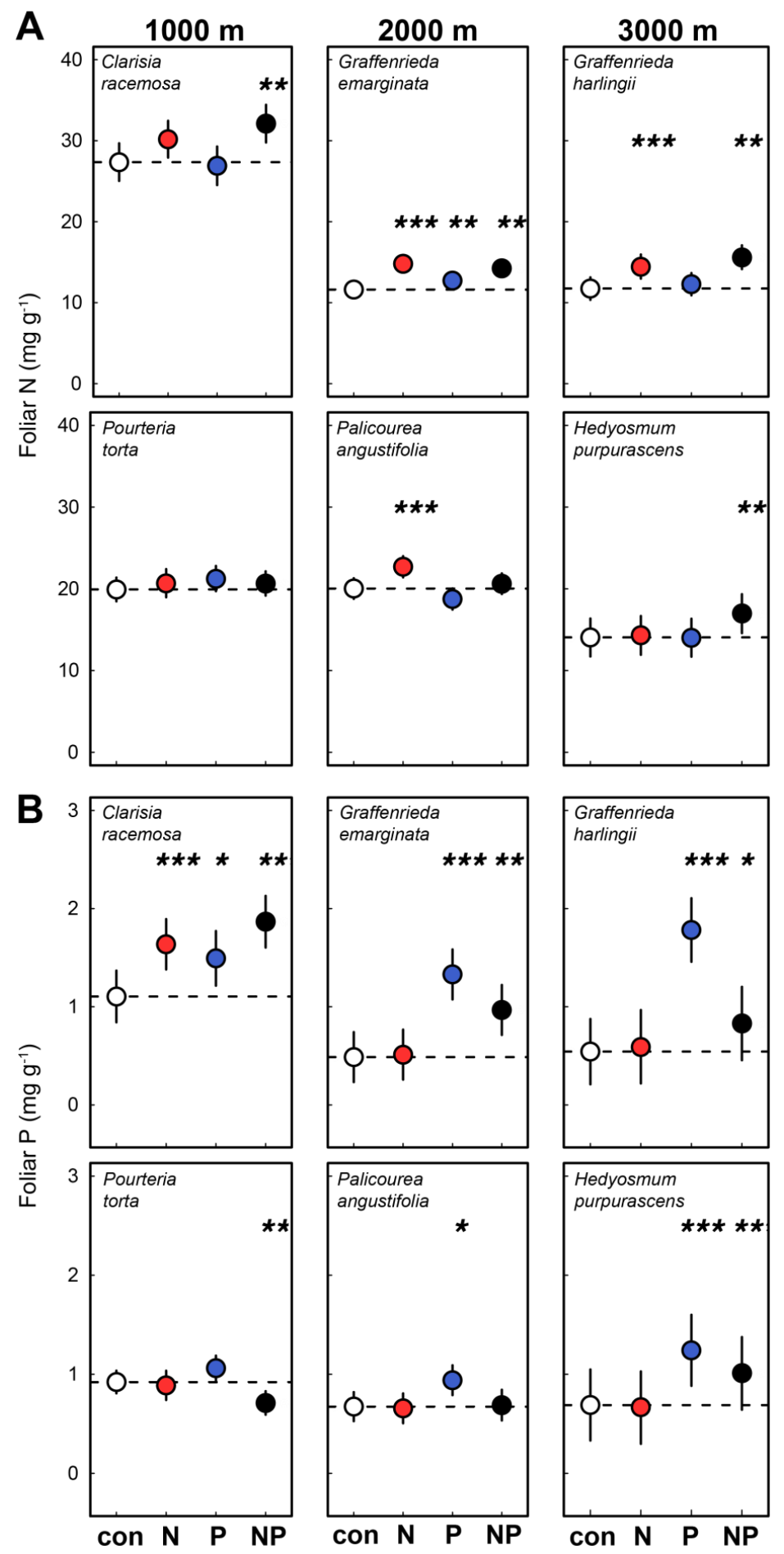

Figure 4.3 Foliar N and P concentrations in the seedlings of six common tree species after N (red), P (blue) or combined $\mathrm{N}$ and $\mathrm{P}$ (black) addition. Mean values were obtained from fitted models and scaled to 95\% confidence intervals. A) Foliar N concentration, B) Foliar P concentration. Significance levels are: * P $<0.05$, $* * \mathrm{P}<0.01, * * * \mathrm{P}<0.001,($.) $\mathrm{P}<0.10$. 

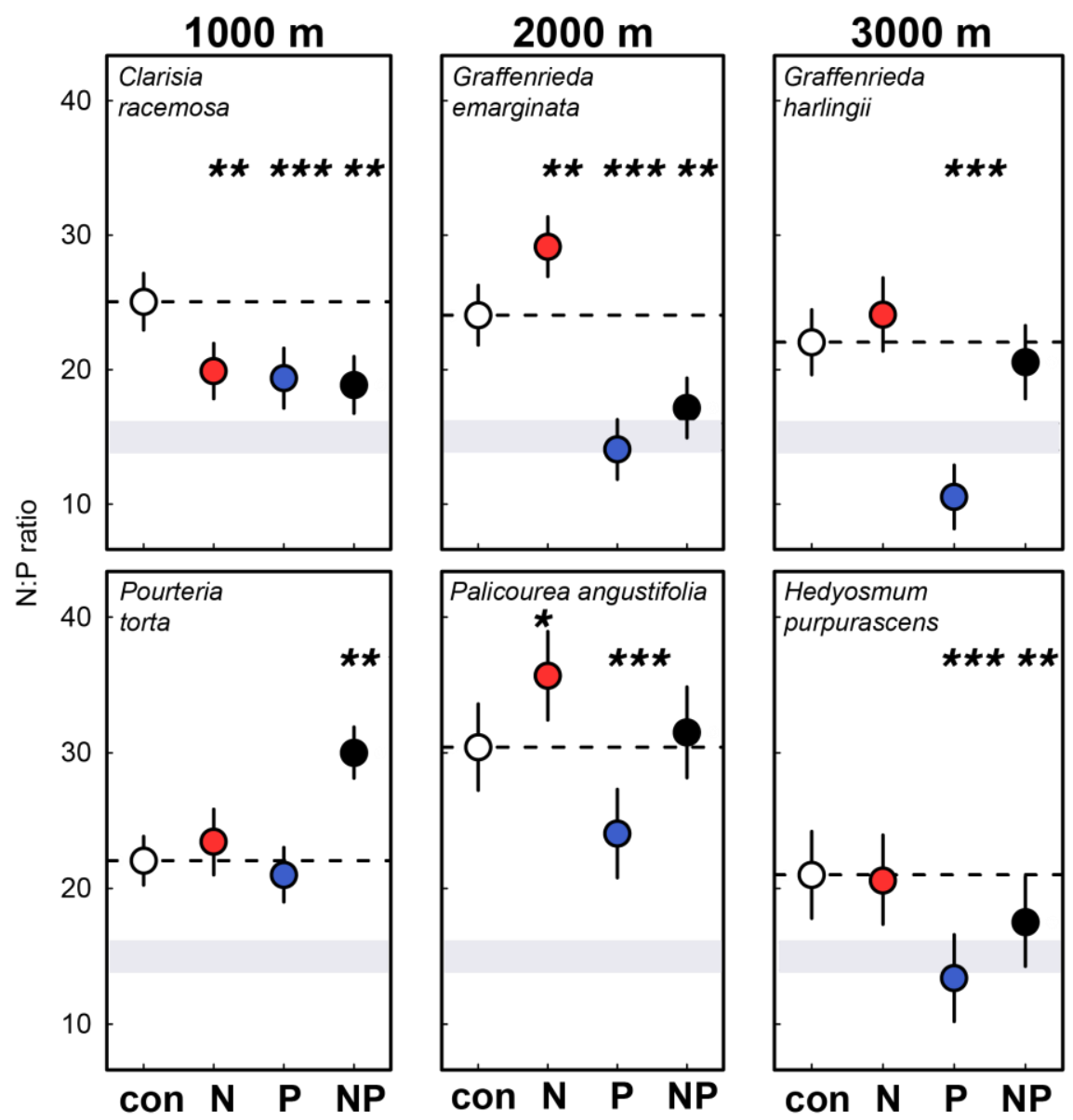

Figure 4.4 Foliar N:P ratios in the seedlings of six common tree species after N (red), P (blue) or combined N and P (black) addition. Following Townsend et al. (2007) and Aerts \& Chapin (2000), values <14 suggest N limitation while $\mathrm{P}$ limitation is given at values >16; the range between these two thresholds is highlighted by the light grey area. Mean values were obtained from fitted models and scaled to $95 \%$ confidence intervals. Significance levels are: $* \mathrm{P}<0.05, * * \mathrm{P}<0.01, * * * \mathrm{P}<0.001$, (.) $\mathrm{P}<0.10$.

\subsubsection{Biomass allocation}

Comparing the fraction of leaves, stem and roots in total seedling biomass, we found strong variation between species and elevations (Figure 5, Table S3). At $1000 \mathrm{~m}$, both species displayed a significant difference in the biomass partitioned to the stems after P addition. In Clarisia, the stem fraction was significantly smaller than in the control plants and also than in the other treatments. Pouteria, in contrast, showed a positive effect of $\mathrm{P}$ on the relative contribution of the stem fraction. At 2000 m, G. emarginata responded to all treatments with an increased stem biomass fraction and had a smaller leaf fraction after $\mathrm{P}$ addition, whereas biomass allocation in Palicourea was not affected at all. In G. harlingii at $3000 \mathrm{~m}$, in all 
Chapter 4

treatments the stem fraction was larger than in the control (difference significant only in the $\mathrm{N}$ and $\mathrm{P}$ treatments). In addition, this species decreased its root fraction in all treatments. At the same elevation, Hedyosmum showed a smaller leaf fraction and an increase of the root fraction in response to $\mathrm{N}$ addition.
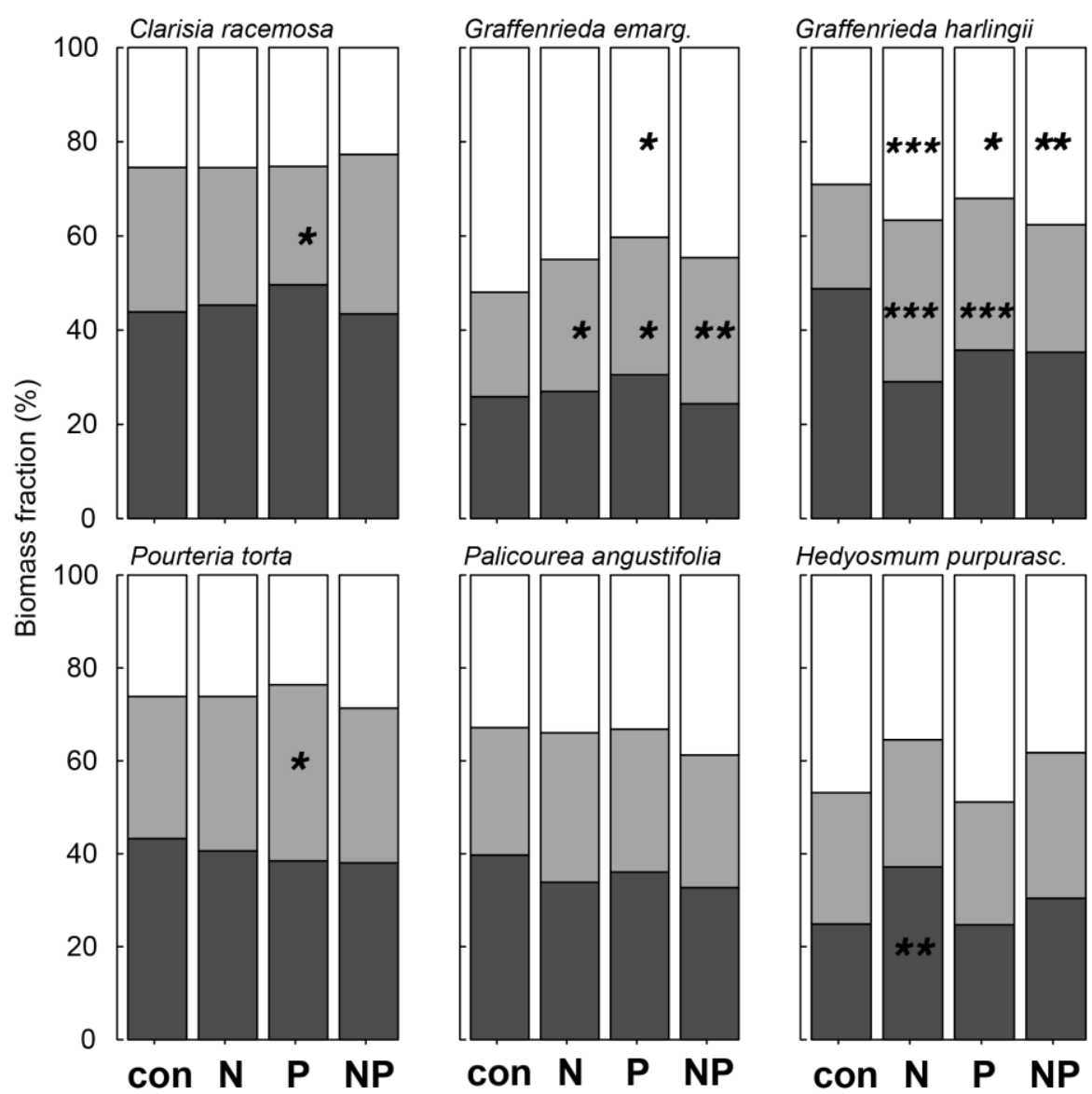

Figure 4.5 Comparison of the proportions of biomass assignable to roots (black), shoots (grey) and leaves (white) in the seedlings of six common tree species after $\mathrm{N}$ or/and $\mathrm{P}$ addition. Significance levels are: * $\mathrm{P}<$ $0.05, * * \mathrm{P}<0.01, * * * \mathrm{P}<0.001,(.) \mathrm{P}<0.10$.

We found no systematic change in the root:shoot ratio with elevation. In all species, the root fraction contributed by $50 \%$ or more of total biomass (Figure 6, Table S3). At the lowest elevation, Clarisia showed a significantly higher root:shoot ratio in seedlings harvested in the $\mathrm{P}$ treatment compared to the control plants. At $2000 \mathrm{~m}$, both species did not adjust their root:shoot ratio after nutrient addition. At $3000 \mathrm{~m}$, G. harlingii seedlings from all 
treatments had lower root:shoot ratios than the control due to a reduced root fraction. In contrast, Hedyosmum showed an increased root:shoot ratio after $\mathrm{N}$ addition.

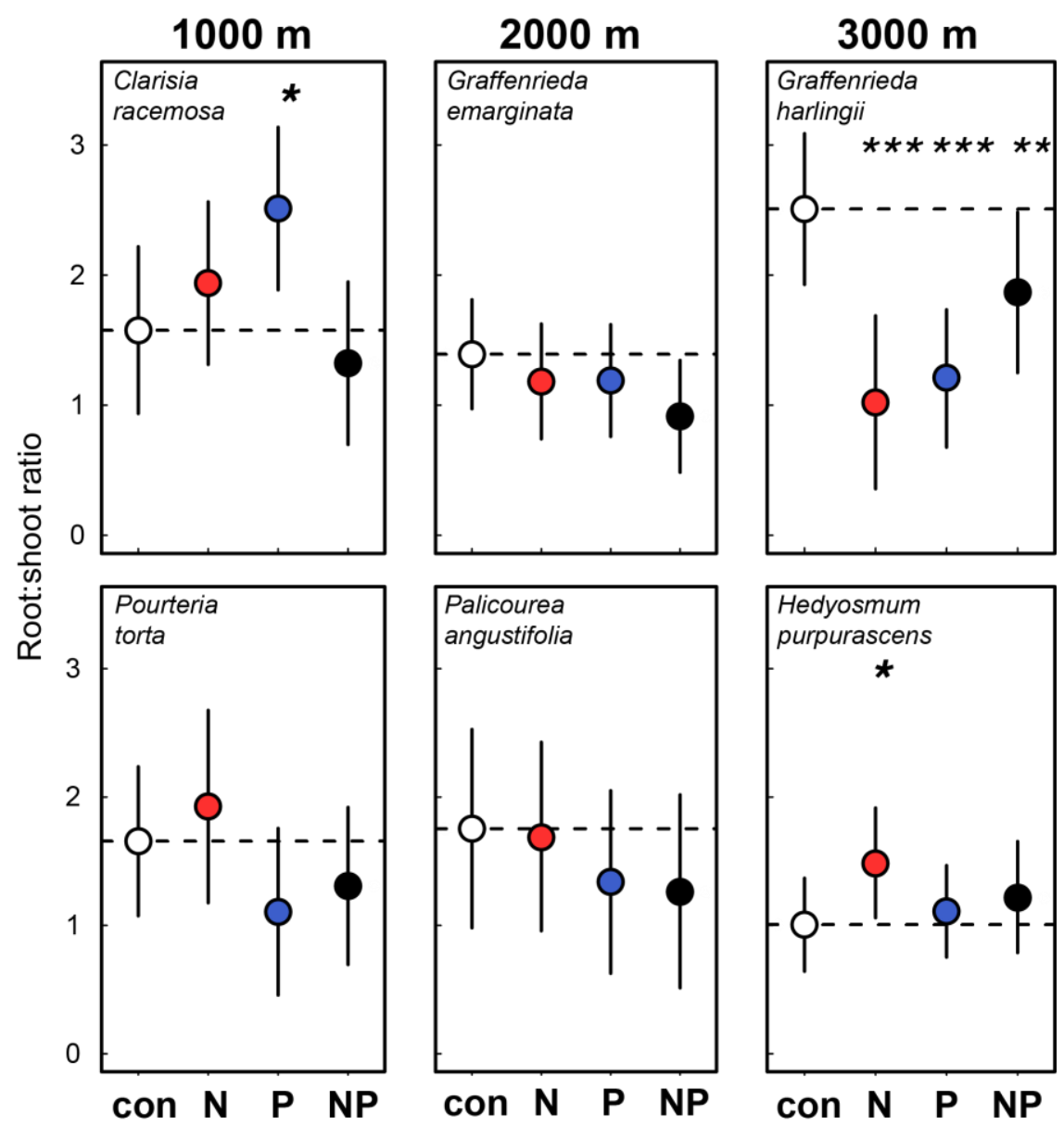

Figure 4.6 Root:shoot ratio of the seedlings of six common tree species after N (red), P (blue) or combined N and $\mathrm{P}$ (black) addition. Mean values were obtained from fitted models and scaled to $95 \%$ confidence intervals. Significance levels are: $* \mathrm{P}<0.05, * * \mathrm{P}<0.01, * * * \mathrm{P}<0.001$, (.) $\mathrm{P}<0.10$.

\subsubsection{Mycorrhizal colonization}

AMF represented the dominant mycorrhizal group in all seedlings, though the two Graffenrieda species were co-colonized by ectomycorrhizae with an average colonization rate of $2 \%$ in G. emarginata and 3\% in G. harlingii (data not presented, no treatment effects observed). The amount of AMF root colonization generally increased with elevation in the control plots (Figure 7). Strongest treatment effects were observed at $2000 \mathrm{~m}$ : in G. 
Chapter 4

emarginata, all three treatments significantly decreased AMF abundance, whereas in Palicourea, only the combined N+P addition exhibited an effect. At $1000 \mathrm{~m}$, no difference to the control was found; at $3000 \mathrm{~m}$, a significant AMF reduction was observed only in Hedyosmum after $\mathrm{N}$ addition.

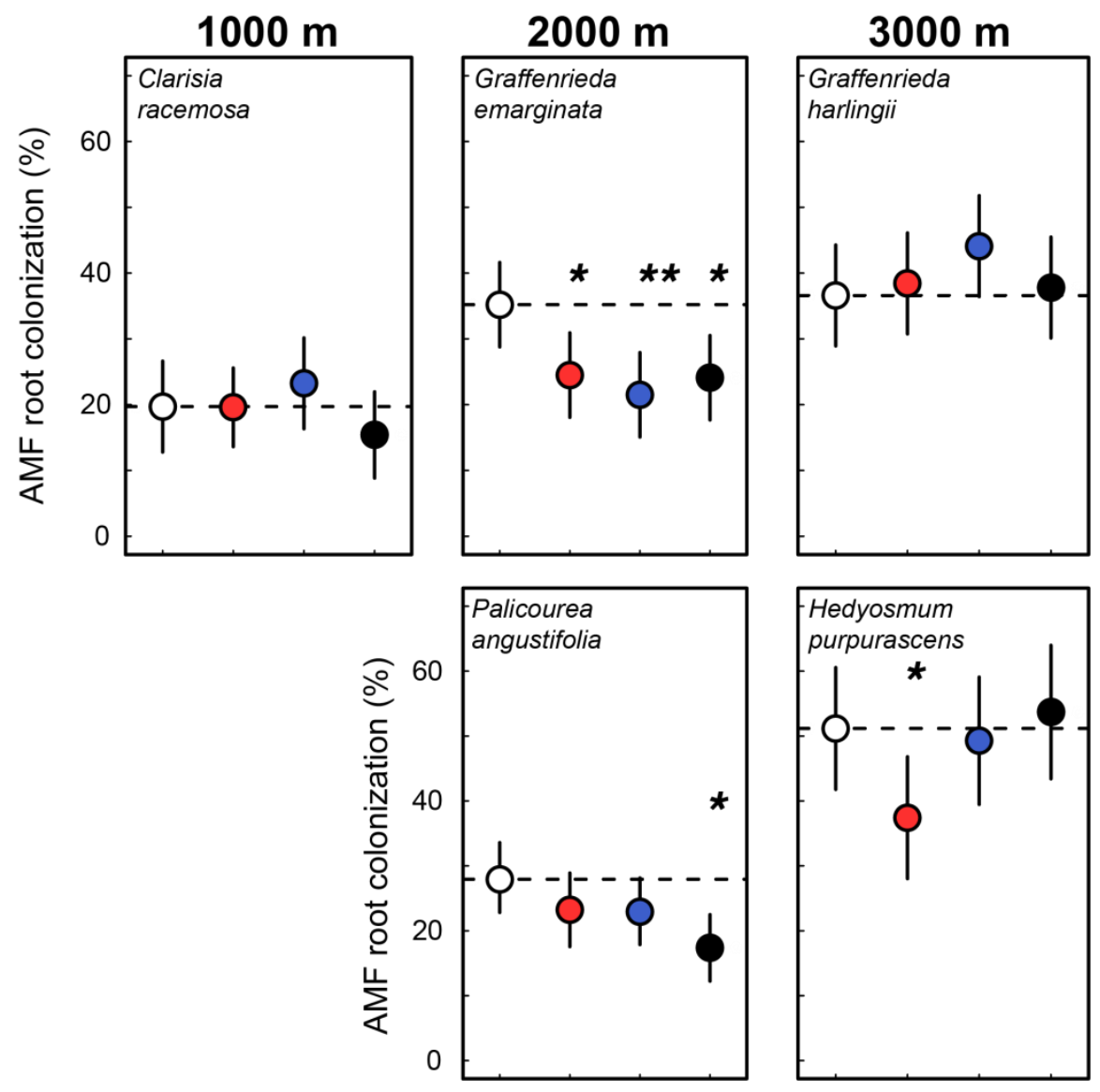

Figure 4.7 Response in the percentage of AMF root colonization to N (red), P (blue) or combined N and P (black) addition. in seedlings of five common tree species. Mean values were obtained from fitted models and scaled to $95 \%$ confidence intervals. Significance levels are: $* \mathrm{P}<0.05$, $* * \mathrm{P}<0.01, * * * \mathrm{P}<0.001$, (.) $\mathrm{P}<0.10$.

\subsection{Discussion}

Our results show that seedling responses to nutrient addition are highly speciesspecific at each elevation level (Table 2). In general, strongest effects were found at 2000 and $3000 \mathrm{~m}$ and some species were more responsive to nutrient addition than others; Seedlings of 
G. harlingii adjusted all studied traits in response to $\mathrm{N}$ and $\mathrm{P}$ addition, while Pouteria seedlings showed only few modifications.

\subsubsection{Leaf morphology, foliar nutrients and herbivory}

Leaf properties are recognized as important traits in determining the establishment and survival success of tree seedlings under varying site conditions. A trade-off has been found between high leaf longevity, leaf toughness and low herbivory on the one hand, and high SLA, foliar nutrient concentrations and seedling growth rates on the other hand (e.g., Poorter \& Bongers, 2006; Wright et al., 2010; Kitajima et al., 2013; Philipson et al., 2014).

The high leaf tissue N:P ratios > 20 in the control plants of all species suggest that $\mathrm{P}$ should limit plant growth at our study sites more than N (Townsend et al., 2007). This matches information gained from foliar N:P ratio data from mature trees in our study sites. The strong effect of $\mathrm{P}$ addition on foliar $\mathrm{P}$ concentration and $\mathrm{N}: \mathrm{P}$ ratio (significant in five species) provides additional evidence for the important role played by P. With the exception of Pouteria (that showed a reduced and not increased foliar $\mathrm{P}$ concentration after combined $\mathrm{N}$ and $\mathrm{P}$ addition), all species were responsive to both added nutrients. Our results coincide with those reported by Homeier et al. (2012), who found a reduction of the foliar N:P ratio after P addition in mature trees of Graffenrieda emarginata and two other common tree species (out of four studied species) after the experiment's first year at the $2000 \mathrm{~m}$ site. Several studies found an increase of foliar nutrient concentrations in shade-tolerant tree seedlings after fertilization (Burslem et al., 1995; Lawrence, 2003; Andersen et al., 2010; Santiago et al., 2012). For Pouteria torta, Cárate-Tandalla et al. (2015) observed in accordance with our findings no effects of nutrient addition on leaf nutrient concentrations in a transplantation experiment with seedlings grown for one year (2011-2012) in the NUMEX plots. They concluded that improved nutrient availability induces higher nutrient uptake only at a rate proportional to the increase in carbon assimilation rate in this species, resulting in a dilution of the added nutrients by carbon and relatively stable foliar nutrient concentrations.

Higher leaf tissue $\mathrm{P}$ concentrations after $\mathrm{N}$ addition as observed in Clarisia might be caused by increased $\mathrm{P}$ acquisition due to higher external phosphatase activity. Such an effect has been observed by Treseder and Vitousek (2001) in Hawaiian rain forests. 
The stronger accumulation of foliar P compared to foliar $\mathrm{N}$ suggests that there is some $\mathrm{P}$ luxury consumption in all species except Pouteria. This species may not be able to acquire additional $\mathrm{P}$ when growth is stimulated by nutrient addition, or it stores additional $\mathrm{P}$ in root and stem tissue but not in the leaves. Luxury consumption of $\mathrm{P}$ was reported for several tropical plant species after P addition (Ostertag, 2010; Mayor et al., 2013), but other species did not respond (e.g., six tropical lowland tree species in Costa Rica; Alvarez-Clare \& Mack, 2015) or even reduced uptake in a similar manner as Pouteria (e.g., the palm Oenocarpus mapora; Mayor et al., 2013). Two studies on tropical tree seedlings (Schreeg et al., 2014) and trees (Mo et al., 2015) suggest that changes in tissue nutrient concentrations after nutrient addition may become more visible in older leaves, stem tissue or roots (these tissues could act as nutrient reservoirs) since the plants try to keep the foliar N:P ratio of young leaves in the range of optimal performance.

We only found significant effects of nutrient addition on the herbivory rate at $2000 \mathrm{~m}$. In G. emarginata, leaf area loss was higher after $\mathrm{N}$ and $\mathrm{NP}$ addition, related to higher foliar $\mathrm{N}$ concentrations in both treatments. In Palicourea, herbivory increased in the $\mathrm{P}$ treatment, where foliar P was higher than in the control. At this site, an earlier study reported increased herbivory on the stand level with higher foliar $\mathrm{N}$ and P concentrations (Werner \& Homeier, 2015). For seedlings of Pouteria torta that were transplanted for one year to our study plots at 1000 m (2011-2012), Cárate.Tandalla et al. (2015) reported an increase in herbivory in the P and $\mathrm{N}+\mathrm{P}$ treated plots. This is in contrast to our results that show only slightly (but not significantly) higher leaf area loss in this species in the same treatments. These contradicting observations may result from inter-annual variation of herbivore pressure.

Herbivory in response to elevated foliar $\mathrm{N}$ levels is a well-studied phenomenon in tropical forests (Campo \& Dirzo, 2003; Eichhorn et al., 2010) which is associated with a preferential choice by predators searching for high-quality food (Andersen et al., 2010). Increased leaf damage by herbivory after $\mathrm{P}$ addition was also reported by Santiago et al. (2012) from a fertilization experiment in Panama where the consumption by herbivores in seedlings was higher after $\mathrm{P}$ or $\mathrm{K}$ addition. These studies show that plant selection by herbivores is strongly driven by resource quality (i.e. nutrient content and palatability of leaves). Damage by herbivores may result from a reduction of assimilating leaf area, but might also be caused by a lowering of photosynthesis rates in the partially damaged leaves (Zangerl et al., 2001; Eichhorn et al., 2010). Thus, herbivory can be an important factor 
structuring seedling communities by negatively affecting the growth and survival of plants or, at least, mediating the responses to increased nutrient availability (e.g., Andersen et al., 2010; Eichhorn et al., 2010; Barton \& Hanley, 2013). Many herbivore species are adapted to specific host taxa, and changes in herbivory rate after nutrient addition may depend on the ability of the herbivores to locate the fertilized plants which might be more suitable for their diet. So, our experiment may also be seen as a test of the responsiveness of herbivores to changed resource availability.

\subsubsection{Biomass partitioning and mycorrhizal colonization}

The carbohydrate allocation patterns observed in the six studied species indicate different strategies with respect to nutrient uptake and accumulation. In accordance with the concept of functional equilibrium discussed by Poorter et al. (2012) and Johnson (2010), seedlings allocate more resources to roots and mycorrhizal structures if nutrients or water are limiting growth, while light limitation should promote shoot growth over root growth. Markesteijn \& Poorter (2009) reported an average root mass fraction (RMF) of 0.3 in seedlings of 37 tropical moist forest tree species; Paz (2007) found RMF site means between 0.12 and 0.31 for seedlings of 55 tree species collected in four Neotropical moist lowland forests and Poorter et al. (2012) reported an average RMF of 0.16 for tropical forest species. In our study, four of the six species partitioned $40 \%$ or more of their biomass to the root system indicating that these species prioritize the maximization of belowground resource acquisition.

Such a strategy may be interpreted as an adaptation to the generally low nutrient availability at our study sites, as is indicated by the observed stimulation of tree root growth after nutrient addition in the ingrowth core experiment of Graefe et al. (2010). Relatively low root:shoot ratios were observed in our experiment in G. emarginata (at $2000 \mathrm{~m}$ ) and Hedyosmum (at $3000 \mathrm{~m}$ ). A possible explanation is that these species are relatively efficient in nutrient acquisition in unfertilized soil due to their mycorrhizal status: G. emarginata shows dual colonization by AMF and ectomycorrhizae (Kottke et al., 2004; Haug et al., 2004) and Hedyosmum had the highest colonization rate by AMF. 
In response to $\mathrm{N}$ and $\mathrm{P}$ addition, we expected a change in biomass partitioning toward aboveground organs in the seedlings (e.g., Marschner, 1995; Poorter et al., 2012). However, G. harlingii was the only species that showed a significant aboveground shift in biomass allocation; this species reduced its investment in root biomass while increasing leaf and stem biomass after $\mathrm{N}, \mathrm{P}$ and $\mathrm{N}+\mathrm{P}$ addition. Its sister species $G$. emarginata did not reduce the root biomass fraction after fertilization; it had a higher percentage of stem tissue in the control and all fertilization treatments. This suggests that seedling height growth is promoted in $G$. harlingii by both $\mathrm{N}$ and $\mathrm{P}$ addition, probably in part driven by a higher photosynthetic capacity due to increased foliar $\mathrm{N}$ concentrations. The percentage of AMF root colonization was reduced in G. emarginata after $\mathrm{N}$ and $\mathrm{P}$ addition, whereas there were no changes in $G$. harlingii. This fact points to different strategies of these congeners with respect to carbohydrate investment in nutrient uptake structures in response to increased $\mathrm{N}$ and $\mathrm{P}$ availability (Johnson, 2010; Ericsson, 1995). The fact that strongest nutrient addition responses in mycorrhization were found at $2000 \mathrm{~m}$ is in line with results obtained from the investigation of mixed tree root samples (Camenzind et al., 2016). However, the direction of effects differs from these observations and species differences seem to be important.

Since both $\mathrm{N}$ and $\mathrm{P}$ caused changes in seedling morphology, chemistry and allocation patterns, we assume that both elements are limiting productivity in our stands as it was suggested for other tropical forest tree species (Lawrence, 2001; Elser et al., 2007; Bracken, et al., 2014). However, since the foliar N:P ratio and the number of affected traits was higher in response to $\mathrm{P}$ addition, it is likely that $\mathrm{P}$ is more effective as a limiting element in the majority of sites in our study region.

Although seedlings may have other nutrient requirements than adult trees, the survival in the seedling community is an essential step for a tree individual in its life cycle. Complementary investigations on seedling growth rates and photosynthetic nutrient use efficiency are needed to reach a more mechanistic understanding of the response of tropical tree seedlings to chronic nutrient addition via deposition. Ideally, such studies should also incorporate measures of light conditions because the light environment and nutrient availability are known to interact in driving seedlings trait variation.

The observed shifts in seedling traits after continued nutrient addition will have consequences for the competitive strength of the studied species. The ongoing increase of 
nutrient deposition to tropical montane forests in the Andes and elsewhere will most likely result in shifts in tree community composition. We observed that uncommon or newlyinvading species benefit from higher nutrient availability and may, therefore, outcompete the currently common species, which predominantly seem to be adapted to less fertile soil conditions.

The responsiveness of the studied tree seedlings to nutrient addition varied largely among the six species, which underlines the need to investigate not only single selected model species but to examine a larger species sample. Data from only a single or very few tropical montane forest tree species seedlings are rarely suitable indicators for assessing the effects of $\mathrm{N}$ and $\mathrm{P}$ addition on plant properties.

\subsection{Supplementary information}

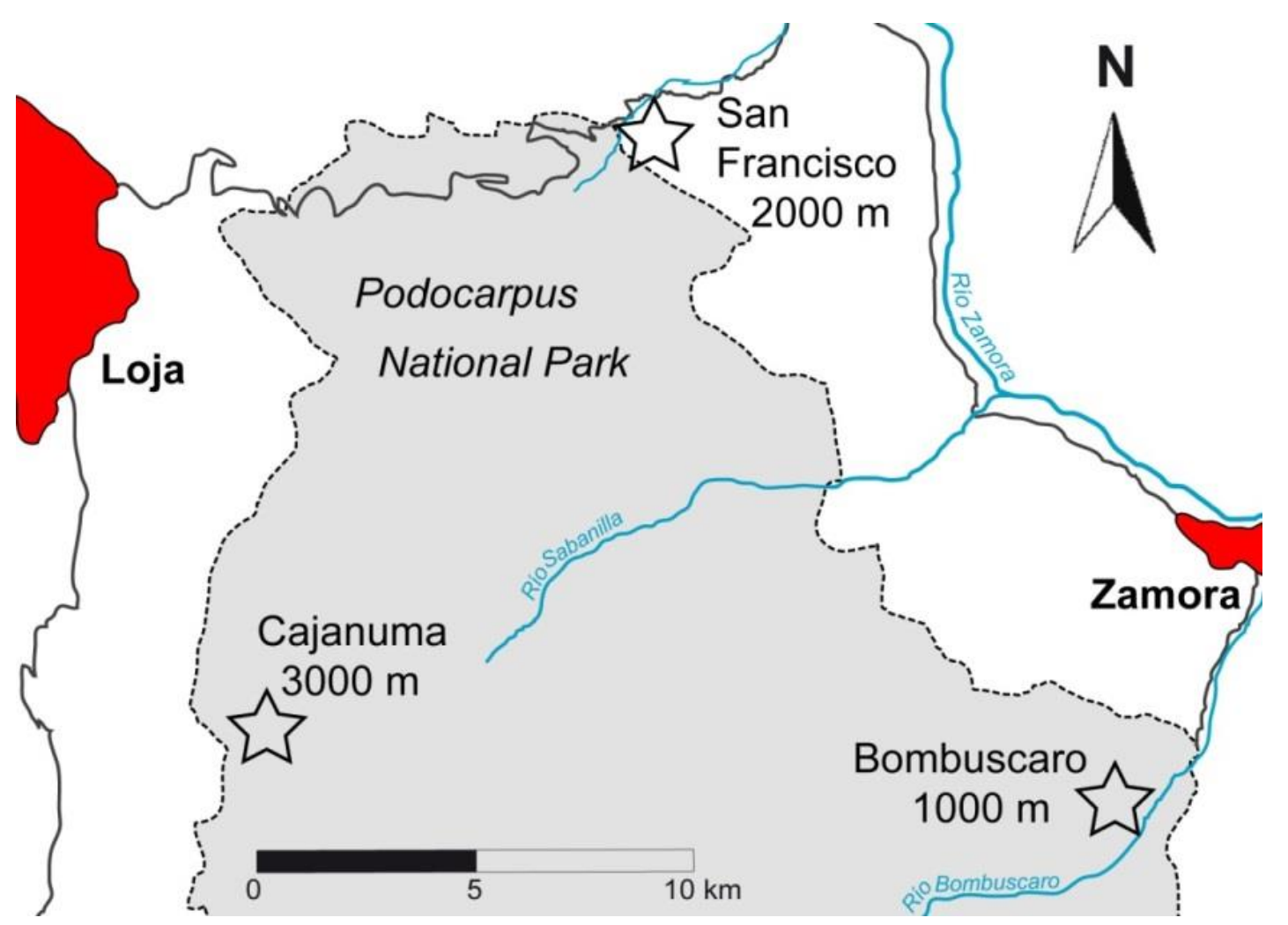

Figure S4.1 Location of the three study sites in Podocarpus National Park and San Francisco Reserve. Every site is marked with a star. 
TableS4.1 Study site soil characteristics after continued nutrient addition.

\begin{tabular}{|c|c|c|c|c|c|c|c|}
\hline $\begin{array}{c}\text { Elevation } \\
\text { (m) }\end{array}$ & Treatment & $\begin{array}{c}\text { pH } \\
\left(\mathbf{H}_{2} \mathbf{O}\right)^{A}\end{array}$ & $\begin{array}{c}\text { Total P } \\
(\mathrm{mg} / \mathrm{kg})^{\mathrm{A}}\end{array}$ & $\begin{array}{c}\mathbf{P}_{\mathbf{i}} \\
(\mathbf{m g} / \mathbf{k g})^{\mathbf{A}}\end{array}$ & $\begin{array}{l}\text { Total N } \\
\left(\mathrm{g} \mathrm{m}^{-2}\right)^{B}\end{array}$ & $\begin{array}{c}\mathrm{NH}_{4} \\
\left(\mathrm{mg} \mathrm{N} \mathrm{m}^{-2}\right)^{\mathrm{C}}\end{array}$ & $\begin{array}{c}\mathrm{NO}_{3} \\
\left(\mathrm{mg} \mathrm{N} \mathrm{m}^{-2}\right)^{\mathrm{C}}\end{array}$ \\
\hline \multirow[t]{4}{*}{1000} & control & $4.7 \pm 0.5$ & $450 \pm 28$ & $45 \pm 9$ & $168 \pm 35$ & $336 \pm 31.38$ & $43.41 \pm 26.01^{\mathrm{c}}$ \\
\hline & $+\mathrm{N}$ & $4.4 \pm 0.4$ & $488 \pm 67$ & $52 \pm 10$ & $172 \pm 27$ & $309 \pm 25.59$ & $76.07 \pm 15.40^{\mathrm{a}}$ \\
\hline & $+\mathrm{P}$ & $4.6 \pm 0.4$ & $516 \pm 58$ & $47 \pm 11$ & $139 \pm 13$ & $317 \pm 15.62$ & $19.44 \pm 8.33^{\mathrm{d}}$ \\
\hline & $+\mathrm{N}+\mathrm{P}$ & $4.4 \pm 0.3$ & $452 \pm 49$ & $52 \pm 14$ & $181 \pm 35$ & $328 \pm 55.86$ & $58.60 \pm 7.88^{\mathrm{b}}$ \\
\hline \multirow[t]{4}{*}{2000} & control & $4.4 \pm 0.4$ & $527 \pm 22^{\mathrm{b}}$ & $129 \pm 11^{\mathrm{bc}}$ & $167 \pm 12$ & $360 \pm 17.12^{\mathrm{c}}$ & $9.59 \pm 2.33^{\mathrm{b}}$ \\
\hline & $+\mathrm{N}$ & $4.0 \pm 0.1$ & $527 \pm 16^{\mathrm{b}}$ & $105 \pm 12^{\mathrm{c}}$ & $169 \pm 6$ & $746 \pm 49.82^{\mathrm{a}}$ & $44.08 \pm 14.81^{\mathrm{a}}$ \\
\hline & $+\mathrm{P}$ & $4.1 \pm 0.2$ & $868 \pm 42^{\mathrm{a}}$ & $253 \pm 32^{\mathrm{a}}$ & $161 \pm 4$ & $325 \pm 20.85^{\mathrm{c}}$ & $8.78 \pm 2.33^{\mathrm{b}}$ \\
\hline & $+\mathrm{N}+\mathrm{P}$ & $4.5 \pm 0.5$ & $783 \pm 16^{\mathrm{a}}$ & $207 \pm 18^{\mathrm{ab}}$ & $167 \pm 10$ & $563 \pm 57.76^{b}$ & $60.49 \pm 6.46^{\mathrm{a}}$ \\
\hline \multirow[t]{4}{*}{3000} & control & $4.3 \pm 0.3$ & $525 \pm 47^{\mathrm{b}}$ & $70 \pm 7^{\mathrm{b}}$ & $75 \pm 4$ & $218 \pm 10.71^{b}$ & $3.77 \pm 0.83^{\mathrm{c}}$ \\
\hline & $+\mathrm{N}$ & $4.2 \pm 0.3$ & $536 \pm 42^{\mathrm{b}}$ & $66 \pm 12^{\mathrm{b}}$ & $86 \pm 6$ & $505 \pm 99.84^{\mathrm{a}}$ & $22.25 \pm 1.11^{\mathrm{a}}$ \\
\hline & $+\mathrm{P}$ & $4.2 \pm 0.3$ & $844 \pm 39^{a}$ & $159 \pm 26^{\mathrm{a}}$ & $84 \pm 6$ & $160 \pm 9.94^{\mathrm{c}}$ & $2.53 \pm 0.77^{\mathrm{d}}$ \\
\hline & $+\mathrm{N}+\mathrm{P}$ & $4.6 \pm 0.4$ & $706 \pm 84^{\mathrm{ab}}$ & $98 \pm 20^{\mathrm{ab}}$ & $95 \pm 3$ & $248 \pm 64.80^{\mathrm{b}}$ & $6.77 \pm 1.36^{\mathrm{b}}$ \\
\hline
\end{tabular}

A Data on mean ( \pm SE) soil pH, total P (digestion with $\left.\mathrm{HNO}_{3}\right)$ and inorganic P (Bray extraction) in the NUMEX plots were taken from Dietrich et al. (2016). Sampling took place in 2014. B Data on mean $( \pm$ SE) soil total nitrogen stock in the top $5 \mathrm{~cm}$ of the NUMEX plots were taken from Baldos et al. (2015). Sampling took place in 2012. C Data on mean $( \pm$ SE) soil mineral nitrogen concentrations in the top $5 \mathrm{~cm}$ of the NUMEX plots were taken from Müller et al. (2015). N concentrations were measured monthly from month 35 to 56 of nutrient addition (2011-2012). Means with superscript small letters indicate significant differences among treatments for each elevation. 
TableS4.2 Summary of the attributes of harvested seedlings of the six most common species in the three study sites

\begin{tabular}{|c|c|c|c|c|c|c|}
\hline & & num (4 exp. plots) & stem length (cm) & diameter (mm) & leaf number & total biomass (g) \\
\hline \multirow[t]{4}{*}{ Clarisia racemosa } & con & $19(4,5,5,5)$ & $29.92(18.5-42.0)$ & $2.61(1.8-4.5)$ & $5(2-8)$ & $1.22(0.4-2.4)$ \\
\hline & $\mathbf{N}$ & $20(5,5,5,5)$ & $25.14(15.5-36.0)$ & $2.06(1.0-3.4)$ & $4.5(2-10)$ & $0.86(0.2-2.0)$ \\
\hline & $\mathbf{P}$ & $18(5,5,3,5)$ & $23.88(13.0-40.0)$ & $2.29(1.5-3.8)$ & $3.9(1-8)$ & $1.00(0.1-3.7)$ \\
\hline & NP & $19(5,5,4,5)$ & $24.75(13.0-44.0)$ & $2.21(1.0-4.8)$ & $3.4(1-5)$ & $0.68(0.2-2.9)$ \\
\hline \multirow[t]{4}{*}{ Pouteria torta } & con & $20(5,5,5,5)$ & $13.29(6.9-20.0)$ & $2.96(1.0-4.8)$ & $4.3(2-9)$ & $1.76(0.4-4.3)$ \\
\hline & $\mathrm{N}$ & $12(4,0,4,3)$ & $13.29(7.8-18.5)$ & $2.76(0.2-4.6)$ & $4.3(2-7)$ & $2.21(0.8-5.6)$ \\
\hline & $\mathrm{P}$ & $16(5,1,5,5)$ & $14.29(6.7-27.2)$ & $3.39(0.4-10.8)$ & $4.1(2-8)$ & $3.43(0.6-21.0)$ \\
\hline & NP & $18(5,3,5,5)$ & $15.01(8.0-29.0)$ & $3.13(2.0-4.9)$ & $4.7(2-13)$ & $2.54(0.6-12.0)$ \\
\hline \multirow[t]{4}{*}{ Graffenrieda emarginata } & con & $20(5,5,5,5)$ & $12.71(7.5-21.0)$ & $2.42(1.3-5.7)$ & $5.4(4-8)$ & $1.02(0.3-4.1)$ \\
\hline & $\mathrm{N}$ & $20(5,5,5,5)$ & $14.90(8.5-32.0)$ & $2.49(1.2-4.6)$ & $5.4(3-10)$ & $1.07(0.2-4.2)$ \\
\hline & $\mathrm{P}$ & $20(5,5,5,5)$ & $17.11(9.0-35.0)$ & $2.74(1.4-5.0)$ & $5.1(3-8)$ & $1.32(0.3-4.6)$ \\
\hline & NP & $20(5,5,5,5)$ & $17.69(10.0-40.0)$ & $2.57(1.3-5.4)$ & $5.3(3-10)$ & $1.15(0.3-5.2)$ \\
\hline \multirow[t]{4}{*}{ Palicourea angustifolia } & con & $20(5,5,5,5)$ & $17.83(11.5-31.0)$ & $1.49(0.8-2.5)$ & $12.3(7-22)$ & $0.32(0.1-1.3)$ \\
\hline & $\mathrm{N}$ & $19(5,5,5,4)$ & $21.88(11.0-43.0)$ & $1.68(1.0-2.7)$ & $13.6(8-21)$ & $0.46(0.1-1.2)$ \\
\hline & $\mathrm{P}$ & $19(5,4,5,5)$ & $21.92(12.0-40.0)$ & $1.54(1.0-2.5)$ & $12.6(6-21)$ & $0.56(0.1-2.1)$ \\
\hline & NP & $20(5,5,5,5)$ & $15.55(10.0-30.0)$ & $1.43(0.8-2.0)$ & $11.7(7-25)$ & $0.25(0.1-0.9)$ \\
\hline \multirow[t]{4}{*}{ Graffenrieda harlingii } & con & $19(5,5,4,5)$ & $18.47(9.0-37.0)$ & $2.38(1.0-4.6)$ & $9.6(3-18)$ & $1.26(0.2-2.9)$ \\
\hline & $\mathrm{N}$ & $15(4,5,5,1)$ & $19.07(11.0-28.5)$ & $3.04(1.8-4.3)$ & $6.4(3-10)$ & $1.06(0.3-2.8)$ \\
\hline & $\mathrm{P}$ & $20(5,5,5,5)$ & $18.75(2.5-29.5)$ & $3.07(1.0-5.2)$ & $9.1(3-25)$ & $1.24(0.3-3.5)$ \\
\hline & NP & $15(2,5,5,3)$ & $18.67(11.0-49.0)$ & $2.39(1.6-3.0)$ & $8(4-13)$ & $0.76(0.2-1.7)$ \\
\hline \multirow[t]{4}{*}{ Hedyosmum purpuracens } & con & $20(5,5,5,5)$ & $17.13(11.0-30.0)$ & $3.31(1.1-5.7)$ & $9.9(5-20)$ & $1.26(0.2-4.2)$ \\
\hline & $\mathrm{N}$ & $15(5,5,5,0)$ & $17.60(10.0-29.5)$ & $2.96(1.7-4.2)$ & $8.9(4-15)$ & $1.01(0.3-2.8)$ \\
\hline & $\mathrm{P}$ & $20(5,5,5,5)$ & $15.38(9.0-33.0)$ & $2.63(1.0-4.4)$ & $10.6(6-20)$ & $0.63(0.2-1.6)$ \\
\hline & NP & $14(5,5,4,0)$ & $19.59(11.0-32.5)$ & $2.80(1.3-3.8)$ & $9.2(4-18)$ & $0.83(0.3-1.8)$ \\
\hline
\end{tabular}


Chapter 4

Table S4.3 Summary of mean values of the attributes analyzed in the six most common species.

Significant levels are given: * $\mathrm{P}<0.05 ; * * \mathrm{P}<0.01 ; * * * \mathrm{P}<0.001 ; \quad$ ns $\mathrm{P}>0.05$.

\begin{tabular}{|c|c|c|c|c|c|c|c|c|c|c|c|c|c|}
\hline & $\begin{array}{c}\text { Foliar N } \\
(\mathrm{mg} / \mathrm{g})\end{array}$ & $\begin{array}{c}\text { Foliar P } \\
(\mathrm{mg} / \mathrm{g})\end{array}$ & $\begin{array}{l}\mathrm{C}: \mathrm{N} \\
\text { ratio }\end{array}$ & $\begin{array}{l}\mathrm{N}: P \\
\text { ratio }\end{array}$ & $\begin{array}{c}\text { SLA } \\
\left(\mathrm{cm}^{2} / \mathrm{g}\right) \\
\end{array}$ & $\begin{array}{c}\text { LAR } \\
\left(\mathrm{cm}^{2} / \mathrm{g}\right) \\
\end{array}$ & $\begin{array}{c}\mathbf{T A} \\
\left(\mathbf{c m}^{2}\right)\end{array}$ & $\begin{array}{c}\text { R:S } \\
\text { ratio }\end{array}$ & $\begin{array}{l}\text { Root } \\
\text { frac }\end{array}$ & $\begin{array}{l}\begin{array}{l}\text { Stem } \\
\text { frac }\end{array} \\
\end{array}$ & $\begin{array}{l}\text { Leaf } \\
\text { frac }\end{array}$ & Slenderness & $\begin{array}{c}\text { Herbivory } \\
(\%)\end{array}$ \\
\hline \multicolumn{14}{|c|}{1000 m.a.s.l. } \\
\hline \multicolumn{14}{|c|}{ Clarisia racemosa } \\
\hline con & 27.329 & 1.11 & 16.65 & 25.06 & 266.44 & 71.21 & 73.64 & 1.58 & 43.88 & 30.68 & 25.44 & 119.50 & 0.86 \\
\hline $\mathrm{N}$ & $30.19 n s$ & $1.64 * * *$ & 15.54 & $19.90 * * *$ & 279.29 & 67.91 & 57.70 & 1.94 & 45.31 & 29.17 & 25.51 & 130.72 & $0.839 n s$ \\
\hline $\mathrm{P}$ & 26.91 & $1.49 *$ & 17.20 & $19.37 * * *$ & 263.49 & 67.99 & 60.91 & $2.51 *$ & 49.63 & $25.14 *$ & 25.23 & 106.80 & $0.65 n s$ \\
\hline $\mathrm{NP}$ & $32.11 * *$ & $1.87 * * *$ & $14.37 *$ & $18.87 * * *$ & $319.89 *$ & 73.82 & $35.82 * * *$ & 1.32 & 43.47 & 33.87 & 22.67 & 118.47 & 1.23 \\
\hline \multicolumn{14}{|c|}{ Pouteria torta } \\
\hline con & 19.93 & 0.92 & 24.89 & 22.05 & 247.69 & 63.98 & 105.32 & 1.66 & 43.28 & 30.57 & 26.15 & 90.33 & 1.99 \\
\hline $\mathrm{N}$ & 20.50 & 0.89 & 24.32 & 23.31 & 223.25 & 59.08 & 118.81 & 1.93 & 40.61 & 33.24 & 26.16 & 140.26 & 2.06 \\
\hline $\mathrm{P}$ & 21.04 & 1.06 & 24.05 & 20.93 & $209.72 *$ & $50.08 *$ & 134.13 & $1.11 n s$ & $38.46 n s$ & $37.91 *$ & 23.63 & 137.45 & 2.54 \\
\hline NP & 20.56 & $0.71 * * *$ & 24.02 & $29.98 * * *$ & 237.26 & 67.40 & 174.53 & 1.31 & 38.06 & 33.28 & 28.66 & 86.67 & 3.12 \\
\hline \multicolumn{14}{|c|}{2000 m.a.s.l. } \\
\hline \multicolumn{14}{|c|}{ Graffenrieda emarginata } \\
\hline con & 11.63 & 0.49 & 41.05 & 24.05 & 215.79 & 115.76 & 90.18 & 1.39 & 25.86 & 22.21 & 51.93 & 57.37 & 1.05 \\
\hline $\mathrm{N}$ & $14.80 * * *$ & 0.51 & $32.51 * * *$ & $29.15 * *$ & 222.85 & 108.17 & 91.70 & 1.18 & 26.97 & $28.04 *$ & 47.74 & 63.74 & $4.056^{* *}$ \\
\hline $\mathrm{P}$ & $12.73^{*}$ & $1.33 * * *$ & 37.08** & $14.07 * * *$ & 237.21 & 103.34 & 104.17 & 1.19 & 30.54 & $29.20 *$ & $41.91 *$ & 63.86 & 2.16 \\
\hline NP & $14.25 * * *$ & $0.97 * * *$ & 33.20*** & $17.16 * * *$ & 234.29 & 112.20 & 94.16 & 0.91 & 24.37 & $31.04 * *$ & 45.69 & 70.43* & $2.765^{*}$ \\
\hline \multicolumn{14}{|c|}{ Palicourea angustifolia } \\
\hline con & 20.04 & 0.67 & 21.63 & 30.42 & 283.82 & 104.98 & 29.86 & 1.73 & 39.73 & 27.45 & 37.05 & 123.61 & 1.63 \\
\hline $\mathrm{N}$ & $22.71 * *$ & 0.66 & $19.34 *$ & $35.64 *$ & 295.18 & 114.79 & 40.14 & 1.67 & $33.88 n s$ & 32.17 & $38.39 n s$ & 130.30 & 1.59 \\
\hline $\mathrm{P}$ & 18.76 & $0.94 *$ & 23.10 & $24.06^{* *}$ & 260.05 & 87.01 & 40.22 & 1.35 & 36.07 & 30.77 & 33.16 & $145.33 *$ & $2.97 n s$ \\
\hline NP & 20.63 & 0.69 & 21.47 & 31.53 & 355.66 & 149.55 & 29.41 & 1.24 & 32.74 & 28.54 & 40.94 & 111.73 & 1.54 \\
\hline
\end{tabular}


Table 4.2 (Continued)

\begin{tabular}{|c|c|c|c|c|c|c|c|c|c|c|c|c|c|}
\hline & $\begin{array}{c}\text { Foliar N } \\
(\mathrm{mg} / \mathrm{g})\end{array}$ & $\begin{array}{c}\text { Foliar P } \\
(\mathrm{mg} / \mathrm{g})\end{array}$ & $\begin{array}{l}\mathrm{C}: \mathrm{N} \\
\text { ratio }\end{array}$ & $\begin{array}{l}\mathrm{N}: \mathrm{P} \\
\text { ratio }\end{array}$ & $\begin{array}{c}\text { SLA } \\
\left(\mathrm{cm}^{2} / \mathrm{g}\right)\end{array}$ & $\begin{array}{c}\text { LAR } \\
\left(\mathrm{cm}^{2} / \mathrm{g}\right)\end{array}$ & $\begin{array}{c}\text { TA } \\
\left(\mathbf{c m}^{2}\right)\end{array}$ & $\begin{array}{l}\mathrm{R}: \mathrm{S} \\
\text { ratio }\end{array}$ & $\begin{array}{l}\text { Root } \\
\text { frac }\end{array}$ & $\begin{array}{c}\text { Stem } \\
\text { frac }\end{array}$ & $\begin{array}{l}\text { Leaf } \\
\text { frac }\end{array}$ & Slenderness & $\begin{array}{c}\text { Herbivory } \\
(\%)\end{array}$ \\
\hline \multicolumn{14}{|c|}{3000 m.a.s.l. } \\
\hline \multicolumn{14}{|c|}{ Graffenrieda harlingii } \\
\hline con & 11.79 & 0.54 & 38.96 & 22.04 & 204.58 & 60.27 & 60.16 & 2.52 & 48.8 & 22.17 & 29.72 & 81.13 & 2.42 \\
\hline $\mathrm{N}$ & $14.15^{* * * *}$ & 0.59 & $34.21 * *$ & 24.04 & 233.34 & $89.73^{*}$ & 76.51 & $0.98 * * *$ & $29.05 * * *$ & $34.31 * * *$ & 36.63 & 63.10 & 3.34 \\
\hline$P$ & 12.28 & $1.78 * * *$ & 37.64 & $10.54 * *$ & 214.15 & 69.36 & 75.11 & $1.21 * *$ & $35.77 *$ & $32.22 * * *$ & 32.01 & $64.98 *$ & 2.00 \\
\hline NP & $15.36 * * *$ & $0.83 *$ & 30.52*** & 20.65 & 245.97 & 94.03** & 58.09 & $1.86 *$ & $35.31 * *$ & $27.08 n s$ & $37.61 n s$ & 77.08 & 2.08 \\
\hline \multicolumn{14}{|c|}{ Hedyosmum purpuracens } \\
\hline con & 14.05 & 0.69 & 32.88 & 21.00 & 185.40 & 87.41 & 87.60 & 1.01 & 24.90 & 28.23 & 46.87 & 60.73 & 1.73 \\
\hline $\mathrm{N}$ & 14.66 & 0.76 & 31.18 & 19.52 & 204.67 & 73.49 & 65.20 & $1.45 *$ & $37.18 * *$ & 27.37 & 35.46 & 60.28 & 1.91 \\
\hline$P$ & 14.02 & $1.24 * * *$ & 31.89 & $13.40 * * *$ & 213.62* & 104.80ns & $60.94 n s$ & 1.11 & 24.71 & 26.45 & 48.84 & 60.59 & 2.53 \\
\hline NP & $17.40^{* * * *}$ & $1.12 * * *$ & $26.32 * * *$ & $16.41^{* *}$ & $216.93^{*}$ & 87.60 & 67.32 & 1.17 & 30.43 & 31.35 & 39.82 & $72.18 n s$ & $2.20 n s$ \\
\hline
\end{tabular}




\section{Chapter 5}

with Christoph Leuschner and Jürgen Homeier

Published in "Frontiers in Earth Science", 2015

doi: 10.3389/feart.20 


\subsection{Summary}

Nitrogen deposition to tropical forests is predicted to increase in many regions due to agricultural intensification. We conducted a seedling transplantation experiment in a tropical premontane forest in Ecuador with a locally abundant late-successional trees pecies (Pouteria torta, Sapotaceae) aimed at detecting species-specific responses to moderate $\mathrm{N}$ and $\mathrm{P}$ addition and to understand how increasing nutrient availability will affect regeneration. From locally collected seeds, 320 seedlings were produced and transplanted to the plots of the Ecuadorian Nutrient Manipulation Experiment (NUMEX) with three treatments (moderate N addition: 50 $\mathrm{kg} \mathrm{N}$ ha-1 year-1, moderate $\mathrm{P}$ addition: $10 \mathrm{~kg} \mathrm{P}$ ha-1 year-1 and combined $\mathrm{N}$ and $\mathrm{P}$ addition) and a control ( 80 plants per treatment). After 12 months, mortality, relative growth rate, leaf nutrient content and leaf herbivory rate were measured. $\mathrm{N}$ and $\mathrm{N}+\mathrm{P}$ addition significantly increased the mortality rate ( 70 vs. $54 \%$ in the control). However, $\mathrm{N}$ and $\mathrm{P}$ additional increased the diameter growth rate of the surviving seedlings. $\mathrm{N}$ and $\mathrm{P}$ addition did not alter foliar nutrient concentrations and leaf $\mathrm{N}: \mathrm{P}$ ratio, but $\mathrm{N}$ addition decreased the leaf $\mathrm{C}: \mathrm{N}$ ratio and increased SLA. $\mathrm{P}$ addition (but not $\mathrm{N}$ addition) resulted in higher leaf area loss to herbivore consumption and also shifted carbon allocation to root growth. This fertilization experiment with a common rain forest tree species conducted in old-growth forest shows that moderate doses of added $\mathrm{N}$ and $\mathrm{P}$ are already affecting seedling performance, which will most likely have consequences for the competitive strength in the understory and the recruitment success of $P$. torta. Simultaneous increases in growth, herbivory and mortality rates make it difficult to assess the species' overall performance and predict how a future increase in nutrient deposition will alter the abundance of this species in the Andean tropical montane forests.

Keywords: Ecuador, tree seedlings, diameter growth, herbivory, foliar nutrients, nutrient manipulation experiment, Pouteria torta, seedling transplantation experiment.

\subsection{Introduction}

Phosphorus $(\mathrm{P})$ and nitrogen $(\mathrm{N})$ are understood to limit stand productivity in the majority of terrestrial ecosystems, including tropical forests (Elser et al., 2007; Harpole et al., 2011; Homeier et al., 2012; Vitousek et al., 2010; Tanner et al., 1998). Anthropogenic influences have modified natural nutrient availability worldwide, through pollutants released 
to the atmosphere and the resulting increased deposition to soils. It is expected that increasing nutrient deposition has the potential to alter the dynamics of tropical forest ecosystems causing structural and compositional changes of the plant communities in response to modified availability of limiting elements (e.g., Lewis \& Tanner, 2000; Homeier et al., 2012).

Nutrient effects on tropical forests largely depend on the local conditions. Factors such as temperature, precipitation, soil type and pedogenesis, and local biota determine overall nutrient availability at a specific site and if an element is limiting plant growth. Thus, tropical lowland rainforests growing on old, highly weathered soils under humid conditions at high temperatures are most likely to be P limited, whereas tropical montane forests that are typically exposed to a cooler and wetter climate most often grow on younger or rejuvenated soils where $\mathrm{N}$ is likely to limit plant growth (Unger et al., 2010; Wolf et al., 2011; Fisher et al., 2013; Vitousek et al., 2010; Tanner et al., 1998). In many cases, terrestrial ecosystems seem to be limited by both $\mathrm{N}$ and $\mathrm{P}$. Hence, addition of $\mathrm{N}$ and/or $\mathrm{P}$ may stimulate plant growth (Elser et al., 2007; Harpole et al., 2011).

Since compositional shifts in communities of long-lived organisms like trees need decades to become visible, studies on mature trees will rarely provide information about future changes in forest dynamics caused by increased nutrient availability. In fact, seedlings of tropical rainforest trees have been found to respond more sensitively to changes in nutrient availability (e.g. Lawrence, 2003; Davitt \& Wright, 2008; Dent \& Burslem, 2009; Andersen et al., 2010; Lu et al., 2010; Holste et al., 2011) due to the strong physiological dependence of this stage on resource availability in a highly competitive environment (Kitajima, 1996).

It is known that processes affecting the seedling stage act as a strong selective filter controlling patterns of recruitment and are thereby influencing the future species composition of the forest (Metz et al., 2008; Swaine, 1996; Whitmore, 1996). Therefore, it is crucial to understand the impact of changed nutrient availability at this stage of the life cycle. Several studies have used seedlings of locally abundant tropical tree species to study if these species are able to optimize their resource use after nutrient addition (e.g., Alvarez-Clare et al., 2013; Pasquini \& Santiago, 2012; Lawrence, 2001; Andersen et al., 2010; Yawitt \& Wright, 2008) and concluded that changes in establishment and growth rates might be considered as a key driver of structural changes of tree communities to altered nutrient availability.

Responses to changed nutrient availability will likely depend on the species' life strategy. Some species are expected to rapidly invest extra nutrients to increase growth, especially 
under favorable light conditions, whereas others may rather store nutrients in their tissues (e.g., Huante et al., 1995b; Raaimakers \& Lambers, 1996; Lawrence, 2003). Biomass allocation varies, depending on how seedlings accumulate carbohydrates to aboveground tissues versus root surface (Burslem, et al. 1995; Wan Juliana et al., 2009). Carbon gain and plant growth are highly dependent on leaf traits, in particular photosynthetic capacity and leaf area, which both tend to increase with nutrient addition (Burslem et al., 1995; Pasquini \& Santiago, 2012; Wan Juliana et al, 2009).

Large increases in nutrient availability, however, may also lead to a decrease in density and diversity of the seedling community by altering survival and establishment rates of a share of species because mortality could be altered by increased herbivory, e.g., as a consequence of $\mathrm{N}$ or P accumulation in leaf tissues (Andersen et al., 2010; Santiago et al., 2012). In addition, seedling establishment might be impeded due to soil acidification (Lu et al., 2010) or due to modified competition with other species (Lawrence, 2001).

To study the effects of increased nutrient availability on a locally abundant climax species, we took advantage of the ongoing nutrient manipulation experiment NUMEX in Ecuador. NUMEX was started in 2008 to study if and to what extent $\mathrm{N}$ and $\mathrm{P}$ limitation are controlling tropical montane forest functioning at three elevation levels $(1000 \mathrm{~m}, 2000 \mathrm{~m}$ and $3000 \mathrm{~m})$ and to simulate the effects of future increasing nutrient availability from atmospheric deposition on different ecosystem processes. In southern Ecuador, nutrient deposition has been suggested to largely origin from extensive biomass burning occurring in the Amazon basin leading to increasing depositions of $>10 \mathrm{~kg} \mathrm{~N}^{-1}$ in the last decade (Fabian et al., 2005; Wilcke et al., 2013). The continued nutrient addition in this experiment had already shown effects on various belowground to aboveground compartments in the experiment's first years; in the common tree species at $2000 \mathrm{~m}$, Homeier et al. (2012) found a positive growth response after $\mathrm{N}$ (two out of four species), $\mathrm{P}$ (two out of four species) and $\mathrm{N}+\mathrm{P}$ addition (three out of four species) and an increase of leaf litter production after $\mathrm{N}$ and $\mathrm{N}+\mathrm{P}$ addition suggesting that $\mathrm{N}$ and $\mathrm{P}$ might be co-limiting. At the same site, Camenzind et al. (2014) detected changes in the abundance and species richness of arbuscular mycorrhizal fungi (AMF) after $\mathrm{N}$ and $\mathrm{P}$ addition. At $1000 \mathrm{~m}$, four years of $\mathrm{N}$ and $\mathrm{N}+\mathrm{P}$ addition (but not $\mathrm{P}$ addition alone) resulted in increased mineral $\mathrm{N}$ production and decreased microbial $\mathrm{N}$ retention and microbial biomass $\mathrm{C}$ and $\mathrm{C}: \mathrm{N}$ ratio (Baldos et al., 2015). $\mathrm{N}_{2} \mathrm{O}$ emissions only increased during the first two years of $\mathrm{N}$ and $\mathrm{N}+\mathrm{P}$ addition (but not $\mathrm{P}$ addition alone), and $\mathrm{P}$ 
addition tended to reduce soil $\mathrm{N}$ cycling and to decrease $\mathrm{N}_{2} \mathrm{O}$ fluxes (Martinson et al., 2013; Müller et al., 2015). Morevover, P (but not N) additions increased the amount of water stable soil macroaggregates, which play an important role for soil stability and nutrient cycling (Camenzind et al., submitted). Krashevska et al. (2013) found that the decomposer system (microorganisms and saprophytic fungi) of the studied NUMEX plots responded to the changes in nutrient inputs concluding that at all elevations, microorganisms were generally limited by $\mathrm{N}$ and saprophytic fungi also by $\mathrm{P}$. In addition, $\mathrm{P}$ and $\mathrm{N}+\mathrm{P}$ treatments increased the bioavailable inorganic P concentrations and decreased phosphatase activity (Dietrich et al., submitted).

At the premontane study site at $1000 \mathrm{~m}$ we found an average foliar N:P ratio of 28.0 in 80 unfertilized trees from 25 different plant families sampled at mid-slope position (Homeier et al., unpublished data). We assume that $\mathrm{P}$ is the prevailing limiting nutrient at this site, since according to Townsend et al. (2007) N:P ratios >16 suggest P-limitation. The two other NUMEX sites also show average foliar N:P ratios $>16(2000 \mathrm{~m}: \mathrm{N}: \mathrm{P}$ ratio $=22.1,78$ trees from 31 plant families; $3000 \mathrm{~m}$ : 26.0, 65, 16) (Homeier et al., unpublished data). Thus, the foliar N:P ratio does not indicate a shift to $\mathrm{N}$ limitation towards higher elevations.

To test the response of seedlings of the locally most abundant climax tree species Pouteria torta to continued nutrient addition, we transplanted nine-month-old seedlings to the NUMEX experimental plots at $1000 \mathrm{~m}$ in 2011. Our investigation aimed to test how continued nutrient addition a) will alter mortality and growth rates in seedlings, b) whether leaf morphology, folivory and foliar nutrient concentrations will indicate changed nutrient use (e.g., higher area loss and high foliar $\mathrm{N}$ concentration after $\mathrm{N}$ addition) and c) how biomass partitioning to above and belowground organs will change as a response to extra nutrient availability.

We aimed to understand how $\mathrm{N}$ and $\mathrm{P}$ limitation are influencing seedling growth and vitality in this abundant species and how its dominant role in the forest might change under increasing nutrient deposition. Based on earlier findings on the nutrient response of shadetolerant tropical tree seedlings, we hypothesized that after being released from potential nutrient limitation, Pouteria torta seedlings would primarily respond by accumulating $\mathrm{N}$ and $\mathrm{P}$ in the biomass rather than by increasing its growth rate. 


\subsection{Methods}

\subsubsection{Study site}

The study was conducted in Podocarpus National Park, southern Ecuador (province Zamora-Chinchipe), close to the Bombuscaro entrance ( $\mathrm{S} 4^{\circ} 7^{\prime}, \mathrm{W} 78^{\circ} 58^{\prime}$ ) in the transition zone between tropical lowlands and lower montane forests. Vegetation has been described as evergreen premontane forest with tree heights up to 40m (Homeier et al., 2008), but average stand height is between 20 and $25 \mathrm{~m}$. Most abundant tree families are Fabaceae, Melastomataceae, Moraceae, Myristicaceae, Rubiaceae and Sapotaceae; common tree species are Pouteria torta (Mart.) Radlk. (Sapotaceae) and Clarisia racemosa Ruiz \& Pav. (Moraceae) (Homeier et al., 2008; 2013).

Mean annual temperature at the study site is around $20{ }^{\circ} \mathrm{C}$ and annual mean precipitation $2200 \mathrm{~mm}$, without a clear seasonal pattern (Emck, 2007; T. Peters, unpublished data). Soils are Dystric Cambisols developed from deeply-weathered granodioritic rock of the Jurassic Zamora granitoide formation (Wolf et al., 2011). The mineral soil is covered by a thin layer of decomposing leaves (Ol layer) (Homeier et al., 2013). Soil characteristics (means $\pm \mathrm{SE})$ of the mineral topsoil $(0-5 \mathrm{~cm})$ after four years of nutrient addition (April 2012) are summarized in Supplementary Table S5.1.

\subsubsection{Study species}

The locally most abundant tree species of the old-growth forests at Bombuscaro, Pouteria torta subsp. glabra T. P. Penn., is a late successional shade-tolerant tree species (Wittich et al., 2015; Homeier, own observations), accounting for $9.5 \%$ of the stems $\geq 10 \mathrm{~cm}$ dbh or about 69 stems ha ${ }^{-1}$ in the NUMEX plots. It reaches heights up to $30 \mathrm{~m}$ and about 50 $\mathrm{cm}$ stem diameter and its wood specific gravity is high with $0.79-0.87 \mathrm{~g} \mathrm{~cm}^{-3}$ (Homeier, unpublished data). The species is widely distributed in the Neotropics from Colombia to the Guianas and in western South America to Bolivia. It is known to occur from the lowlands up to $1500 \mathrm{~m}$ (Pennington, 2007). 


\subsubsection{Experimental design}

The full-factorial Ecuadorian nutrient manipulation experiment (NUMEX) was set up at $990-1100 \mathrm{~m}$ in a stratified random design which consists of four blocks with four treatments (control, $\mathrm{N}, \mathrm{P}$ and $\mathrm{N}+\mathrm{P}$ addition) assigned to every block (16 experimental plots). Experimental plots $(20 \times 20 \mathrm{~m})$ were installed in old-growth forest with closed canopy at mid slope position; the plots are separated from each other by at least $10 \mathrm{~m}$-wide strips of untreated forest (Supplementary Figure S5.1).

Fertilizations started in February 2008. Fertilizers are applied by hand to the experimental plots at rates of $50 \mathrm{~kg} \mathrm{~N} \mathrm{ha}^{-1}$ (as urea) in the $\mathrm{N}$ treatment plots, or $10 \mathrm{~kg} \mathrm{P} \mathrm{ha}^{-1}$ $\left(\mathrm{NaH}_{2} \mathrm{PO}_{4}\right)$ in the $\mathrm{P}$ treatment plots, or $50 \mathrm{~kg} \mathrm{~N}$ and $10 \mathrm{~kg} \mathrm{P}(\mathrm{N}+\mathrm{P}$ treatment plots $)$ applied in two portions per year (Homeier et al., 2013). For the seedling experiment, four new subplots of $1 \mathrm{~m}^{2}$ were randomly placed into each NUMEX experimental plot (64 subplots in total). Irradiance at the forest floor was quantified in every subplot with hemispherical photos (Nikon D5000 camera with $8 \mathrm{~mm}$-fish eye lens) taken at the midpoint $1 \mathrm{~m}$ above ground under uniform sky conditions in 2012. Images were analyzed using Gap Light Analyzer 2.0 software (Frazer et al., 1999). Light availability in the subplots indicated a mean canopy openness of $8.85 \pm 4.1(\mathrm{SD}) \%$ with a range of $1.25-19.48 \%$.

Seedlings of Pouteria torta were raised after a massive fruiting event that occurred in 2010. More than 400 seeds from about 15 trees were collected in September 2010 at the study site and sown in a greenhouse supplied by a local farmer. In June 2011, 320 seedlings were selected and transported to the study site. All seedlings were measured for total height and labeled before planting; mean initial height was $17.4 \pm 4.9$ (SE) $\mathrm{cm}$ (Table 5.1). At that time, there were no cotyledons left on the plants and seedlings had completely consumed the reserves stored in the seeds.

Five seedlings were assigned to each experimental subplot. Because of small differences in initial height, we classified seedlings into height categories before planting and then equally distributed them to the 64 subplots to ensure a similar seedling height distribution in each plot. Subplots were also cleaned from other tree seedlings and ground herbs to avoid root competition. Once seedlings were planted, initial size characteristics were measured (stem height and basal diameter, leaf number, length and width of the largest leaf). 
After one year, in May 2012, all surviving seedlings were carefully harvested after a final assessment of basal diameter and leaf area loss. We excavated all seedlings, removed all soil from the roots, and then separated the plants into root, stem and leaf fractions. Fresh leaves were scanned immediately after harvesting seedlings (color, $150 \mathrm{dpi}$ ) with a Cannon LIDE 1000 flatbed scanner. All seedling fractions were dried for 72 hours at $60{ }^{\circ} \mathrm{C}$ and then transferred to Germany.

Table 5.1 Properties of the initial seedling cohort before transplantation to NUMEX plots in June 2011. Means and ranges are given (in parentheses).

\begin{tabular}{lcccc}
\hline \hline Seedling properties & \multicolumn{3}{c}{ Treatments } \\
& Control & $\mathbf{N}$ & $\mathbf{P}$ & $\mathbf{N}+\mathbf{P}$ \\
\hline \multirow{2}{*}{ Height $(\mathrm{cm})$} & 17.2 & 16.8 & 18.1 & 17.4 \\
& $(9.2-31.0)$ & $(5.5-27.0)$ & $(9.5-30.0)$ & $(6.5-29.0)$ \\
Diameter $(\mathrm{mm})$ & 3.0 & 3.0 & 3.0 & 3.1 \\
& $(2.0-4.1)$ & $(1.8-4.0)$ & $(1.7-5.2)$ & $(1.9-4.5)$ \\
Leaf number & 8.0 & 7.3 & 8.0 & 7.4 \\
& $(3-19)$ & $(1-18)$ & $(1-18)$ & $(2-17)$ \\
Leaf length $(\mathrm{cm})$ & 6.7 & 7.4 & 6.7 & 7.6 \\
& $(1.1-14.8)$ & $(2.2-17.0)$ & $(1.4-15.0)$ & $(1.4-17.0)$ \\
Leaf width $(\mathrm{cm})$ & 2.2 & 2.3 & 2.1 & 2.5 \\
& $(0.5-4.0)$ & $(0.4-5.5)$ & $(0.4-4.5)$ & $(0.5-5.0)$ \\
\hline \hline
\end{tabular}

\subsubsection{Leaf analyses}

The scanned images of the Pouteria leaves were analysed using Win Folia 2005b software (Régent Intruments Inc., Quebec City, QC, Canada) to calculate total leaf area including damaged areas (hole area). Subsequently, images were manually adjusted by filling in missing leaf sections, to estimate the original leaf area prior to damage. Specific leaf area (SLA, $\mathrm{cm}^{2} \mathrm{~g}^{-1}$ ) was calculated for each seedling by dividing the entire remaining leaf area of all leaves by its mass. Proportional leaf area loss was determined as an estimate of herbivory rate, the damage inflicted over the life span of the leaves with the following formula:

Leaf area loss $(\%)=$ damaged area $\left(\mathrm{cm}^{2}\right) /$ total original leaf area $\left(\mathrm{cm}^{2}\right)$ 
Chapter 5

Leaf length ratio and leaf width ratio were calculated by dividing the respective dimension of the biggest leaf at harvest and before planting to estimate changes in leaf dimensions during our experiment:

Leaf length ratio $=$ final lamina length $(\mathrm{cm}) /$ initial lamina length $(\mathrm{cm})$

The leaf area ratio (LAR) was calculated as the amount of leaf area per unit of total plant mass.

\subsubsection{Nutrient analyses}

We determined total $\mathrm{N}$ and $\mathrm{C}$ concentrations of the leaf mass with a $\mathrm{C} / \mathrm{N}$ elemental analyzer (Vario EL III, Elementa, Hanau, Germany). Total P concentrations were analyzed using an Inductively Coupled Plasma Analyzer (Optima 5300DV ICP-OES, Perkin Elmer, Waltham, Massachusetts, USA) after digesting the leaf samples with concentrated $\mathrm{HNO}_{3}$. Nutrient analyses were conducted at the laboratory of the Department of Ecology and Ecosystems Research, University of Göttingen, Germany for all individual seedlings harvested at the end of the experiment.

\subsubsection{Data treatment and statistical analyses}

Mortality rates were calculated from the proportion of dead individuals in the subplots (i.e., number of dead seedlings divided by seedlings planted). Effects of nutrients on mortality were tested with a generalized linear mixed model (GLMM) for a binomial distribution using counts of the dead individuals in a full factorial approach using the function "glmer" in the lme4 package (Bates et al., 2014) with $\mathrm{N}$ and $\mathrm{P}$ as fixed effects and "block" as a random factor. Significance values were obtained after testing the model with the "cftest" function from the multcomp package (Hothorn et al., 2008). This function calculates, in a univariate testing way, the p-values from estimated model coefficients obtained from a z-test. The relative stem diameter growth rate $\left(\mathrm{RGR}_{\mathrm{D}}\right)$ was calculated from diameter measurements for the study interval as:

$$
\left(\ln \left(\mathrm{d}_{2}\right)-\ln \left(\mathrm{d}_{1}\right)\right) /\left(\mathrm{t}_{1}-\mathrm{t}_{0}\right),
$$

where $d_{2}$ represents the final diameter and $d_{1}$ the initial diameter, and $t_{1}-t_{0}$ represents the time span between planting and harvesting dates. 
The mass fractions for leaves (LMF), stems (SMF) and roots (RMF) were calculated by relating organ mass to total plant mass for each seedling following Poorter et al. (2012).

Data were transformed to reduce heteroscedasticity when required (log transformations for biomass ratios, leaf area and leaf nutrient contents and sqrt transformations for biomass, leaf fractions and leaf area loss).

To test specifically how nutrients are influencing seedling performance, we used a full factorial linear mixed model with $\mathrm{N}$ and $\mathrm{P}$ as fixed effects using the "lme" function of the nlme package (Pinheiro et al., 2014) for all seedlings measured and harvested in 2012 ( $\mathrm{n}=$ 124). For all parameters assessed $\left(\mathrm{RGR}_{\mathrm{D}}\right.$, SLA, leaf area loss, foliar N/P and C/N ratio, root/shoot and root/leaf ratios, LAR, biomass fractions, foliar nutrient contents), canopy openness was evaluated first in order to check for interaction with fixed effects (treatment). Since it had no influence on the responses to nutrient addition, canopy openness was not included in the final models. In all models, we included "block" as a random factor.

All comparisons contrasted differences between treatments $(\mathrm{N}, \mathrm{P}$ or interaction of $\mathrm{N}$ and $\mathrm{P}$ ) with control. All analyses and figures were done with $\mathrm{R} 3.1 .1$ software (R Development Core Team, 2014). Specific information about the structure of the fitted models all parameters analyzed is summarized in Supplementary Table S5.2.

\subsection{Results}

\subsubsection{Seedling growth and mortality}

The seedlings suffered high mortality (Figure 5.1); only 124 (con=37, N=24, P=39, $\mathrm{N}+\mathrm{P}=24$ ) of the initially planted 320 Pouteria torta seedlings survived the first year. On average, $54 \%(n=43)$ of all seedlings in the control and $51 \%(n=41)$ of those in the P treatment died. $\mathrm{N}$ fertilization increased seedling mortality significantly $(\mathrm{p}=0.016)$ to $70 \%$ $(\mathrm{n}=56)$ in both $\mathrm{N}$ treatments compared with the control (Table 5.2).

The relative diameter growth rate $\left(\mathrm{RGR}_{\mathrm{D}}\right)$ of the surviving seedlings was $0.23 \mathrm{yr}^{-1}$ in the control subplots (Figure 5.2). $\mathrm{N}$ fertilization $(\mathrm{p}=0.006)$ and $\mathrm{P}$ fertilization $(\mathrm{p}=0.021)$ significantly increased diameter growth by 30-50\% compared to the control. 


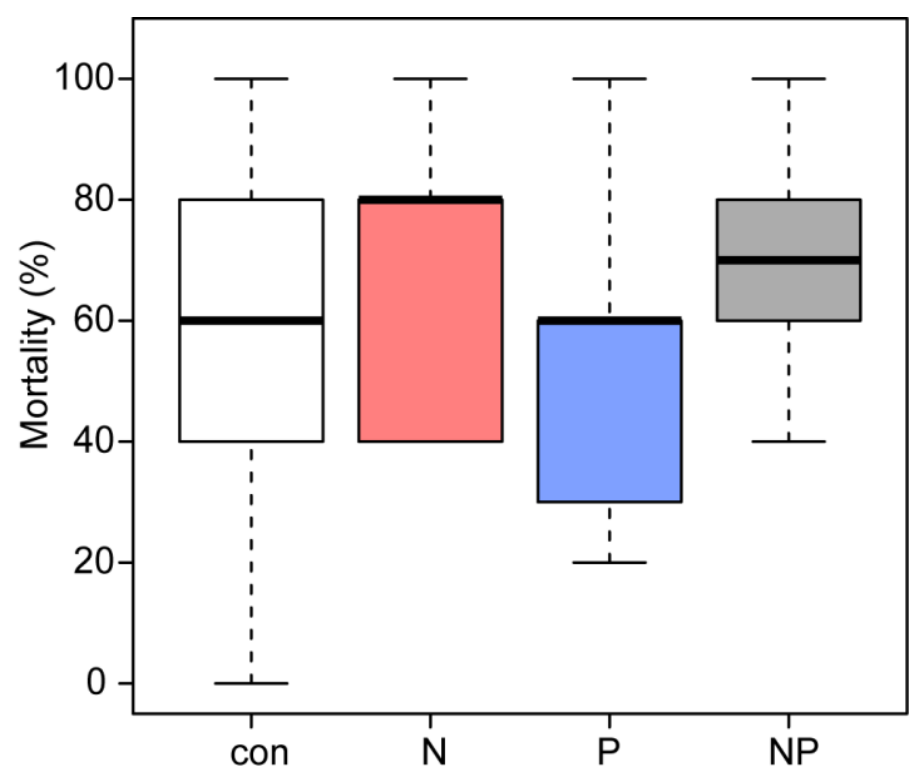

Figure 5.1 Mean percentages of mortality in Pouteria torta seedlings observed during one year of exposure to moderate nutrient additions (2011-2012). Addition of $\mathrm{N}$ and of $\mathrm{N}+\mathrm{P}$ resulted in a significantly higher mortality of the seedlings $(\mathrm{p}=0.016)$.

\subsubsection{Leaf properties and herbivory}

Leaf area showed no significant difference between treatments although largest leaves were found in the $\mathrm{N}$ and $\mathrm{N}+\mathrm{P}$ treatments (Table 5.2). Compared to the control, SLA showed a significant increase of more than $40 \%$ after $\mathrm{N}$ addition (Figure 5.3, Table 5.2). In addition, we observed higher leaf length and leaf width ratios after $\mathrm{N}$ addition, whereas leaves in the control and in the $\mathrm{P}$ addition plots did not increase their dimensions.

Seedlings grown in the $\mathrm{P}$ and $\mathrm{N}+\mathrm{P}$ treatments had highest leaf area losses compared with seedling in control plots indicating a stimulation of herbivory by $\mathrm{P}$ fertilization (Figure 5.3, Table 5.2).

Mass based foliar $\mathrm{N}$ and $\mathrm{P}$ concentrations were only weakly affected by the fertilization since we found only marginally higher foliar $\mathrm{N}$ after $\mathrm{N}$ addition, but the foliar $\mathrm{C} / \mathrm{N}$ ratio was lowered (Figure 5.3). Area-based foliar $\mathrm{N}$ and $\mathrm{P}$ concentrations were lower in the $\mathrm{N}$ treatment.

$\mathrm{N}$ and $\mathrm{P}$ foliar contents on a mass basis (i.e., total foliar nutrient content per plant) showed no differences between treatments. The mean values of foliar N:P ratios varied between the treatments from 15.9 in the control to 17.9 in the $\mathrm{N}+\mathrm{P}$ treatment. 


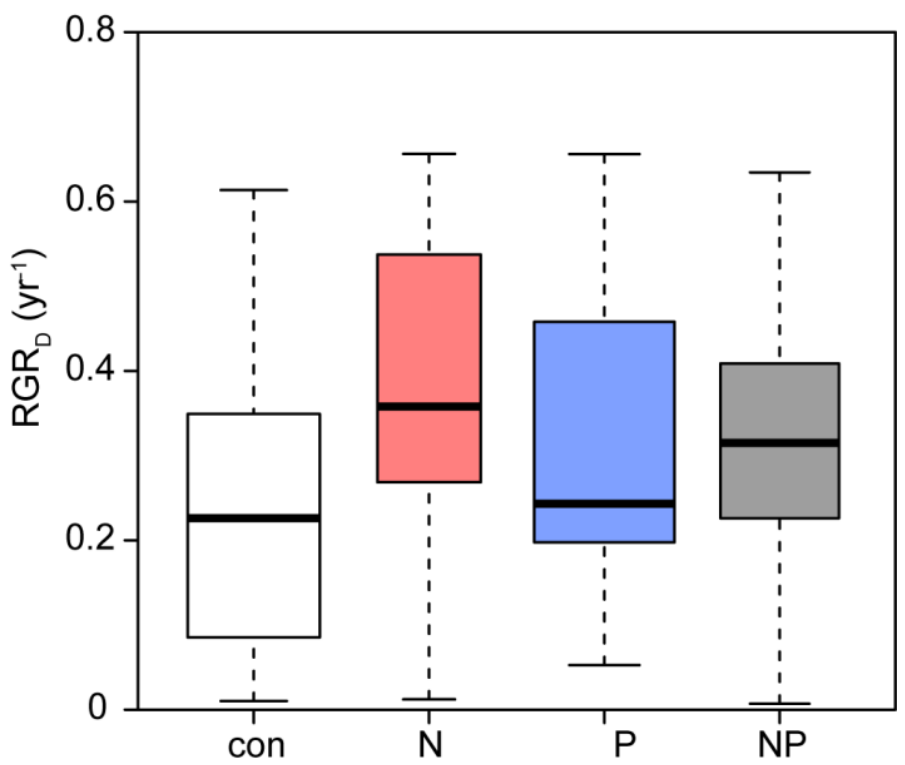

Figure 5.2 Relative diameter growth rates of Pouteria torta seedlings as a response to moderate nutrient addition. Single addition of $\mathrm{N}$ or $\mathrm{P}$ caused increased growth rates $(\mathrm{N}: \mathrm{p}=0.006 ; \mathrm{P}: \mathrm{p}=0.021)$, interaction of both nutrients resulted in a smaller effect than when the elements were added alone $(\mathrm{N}+\mathrm{P}: \mathrm{p}=0.017)$.

\subsubsection{Biomass allocation}

Across all treatments, Pouteria seedlings allocated most of their biomass to the roots (Table 5.2, Figure 5.4). P addition shifted allocation even more to roots as expressed by an increasing root mass fraction (P: 55\%, N+P: $56 \%$ vs. control: $51 \%$ ) and a higher root/shoot ratio (P: 1.87, N+P: 2.07 vs. control: 1.69).

The leaf mass fraction of the seedlings in the $\mathrm{N}$ treatments was significantly reduced $(\mathrm{N}: 12 \%, \mathrm{~N}+\mathrm{P}: 13 \%$ vs. control: $16 \%)$ and the stem mass fraction was higher after $\mathrm{N}$ addition (N: 0.35 vs. control: 0.32 ). Mean LAR was slightly but not significantly higher in the fertilized plots compared to the control. 

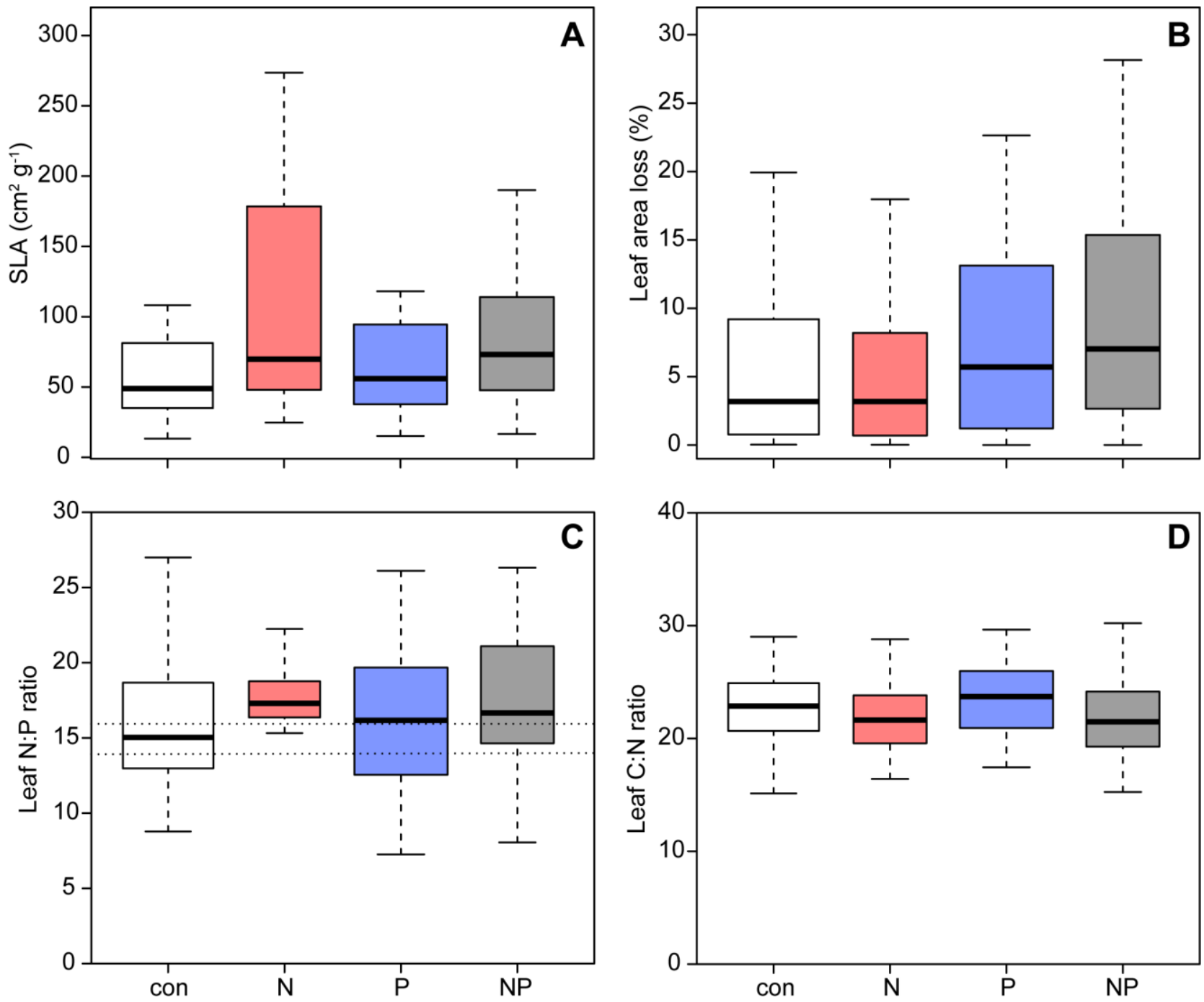

Figure 5.3 Leaf morphology, leaf area loss and nutrient ratios of Pouteria torta seedlings after one year of experimental exposure to nutrient addition. (A) Specific leaf area (SLA) increased after $\mathrm{N}$ addition $(\mathrm{p}=0.009)$, (B) the proportion of lost leaf area showed a significant increment after $\mathrm{P}$ addition $(\mathrm{p}=0.020)$, (C) foliar $\mathrm{N}: \mathrm{P}$ ratio was not affected in the treatments (dotted lines mark the range of N:P ratios indicating a balanced supply of both nutrients after Townsend et al., 2006), and (D) leaf C:N ratio was decreased in the two $\mathrm{N}$ treatments ( $\mathrm{p}=0$ 0.024).

\subsection{Discussion}

\subsubsection{Seedling mortality and growth}

During the life cycle of a tree, the seedling stage is the most vulnerable phase with susceptibility to physical harm (e.g., litterfall, trampling, herbivory or pathogen attack) and 
carbohydrate shortage (Alvarez-Clare \& Kitajima, 2007; 2009). Seedling mortality is highly related to the plants' physical and physiological robustness to withstand adverse conditions in order to establish successfully (Kitajima, 2000; Alvarez-Clare \& Kitajima, 2007).

Under natural forest conditions, seedling transplantation experiments in tropical forests commonly experience high mortality during the first two months after seedling transplantation (Alvarez-Clare \& Kitajima, 2009; Brenes-Arguedas et al., 2011; Eichhorn, et al., 2006), which is mainly attributed to damage by herbivores and defoliation (Paine et al., 2012). In our study, Pouteria torta experienced a high mortality of $>50 \%$ in the first year after planting, although transplantation occurred 6 months after germination when we assumed that the seedlings already had reached a "robust" stage.

The increase in mortality in the two $\mathrm{N}$ treatments is contrary to results of Vincent and Tanner (2013) who reported no reduction of survival rate in transplanted seedlings of two late-successional tree species after NPK addition in a Panamanian lowland forest. Since there was no significant change in soil $\mathrm{pH}$ in our plots after four years of nutrient addition (Supplementary Table S5.1; Baldos et al., 2015), we cannot argue that soil acidification impeded seedling establishment as reported by Lu et al. (2010).

In spite of the complex interaction among drivers of seedling growth under natural forest conditions, we found positive effects of either $\mathrm{N}$ or $\mathrm{P}$ addition on diameter growth of the surviving Pouteria seedlings. Both $\mathrm{N}$ and $\mathrm{P}$ are essential for photosynthesis, since ribulose 1-5-bisphosphate oxygenase/carboxylase ( $\mathrm{RuBisCO}$ ) protein accounts for $\sim 30 \%$ of leaf $\mathrm{N}$, and $\mathrm{P}$ plays an important role in membrane solubility, ATP, and NADPH production (Marschner, 1995; Walker et al., 2014). Since foliar N and P did not increase while SLA increased, an increase in photosynthetic rate cannot be the cause of higher productivity; rather, the (non-significant) increase in plant leaf area must have led to the higher productivity in the fertilized plants. Several other pot experiments with tropical tree seedling showed positive effects of $\mathrm{N}$ and/or $\mathrm{P}$ addition on growth as well, though other studies reported no effects (see compilation in Lawrence, 2003). In general, tree growth limitation by $\mathrm{N}$ and $\mathrm{P}$ depends on specific site conditions and on co-limitation by other nutrients. Santiago et al. (2012) showed a $24 \%$ increase in relative height growth in naturally established tropical tree seedlings as a response to $\mathrm{K}$ addition and a smaller but also positive effect of combined long-term addition of $\mathrm{N}$ and $\mathrm{P}$. Increased growth rates are probably the result of enhanced 
Chapter 5

photosynthetic productivity as reported by Pasquini and Santiago (2012) for Alseis blackiana seedlings from the same tropical lowland forest in Panama.
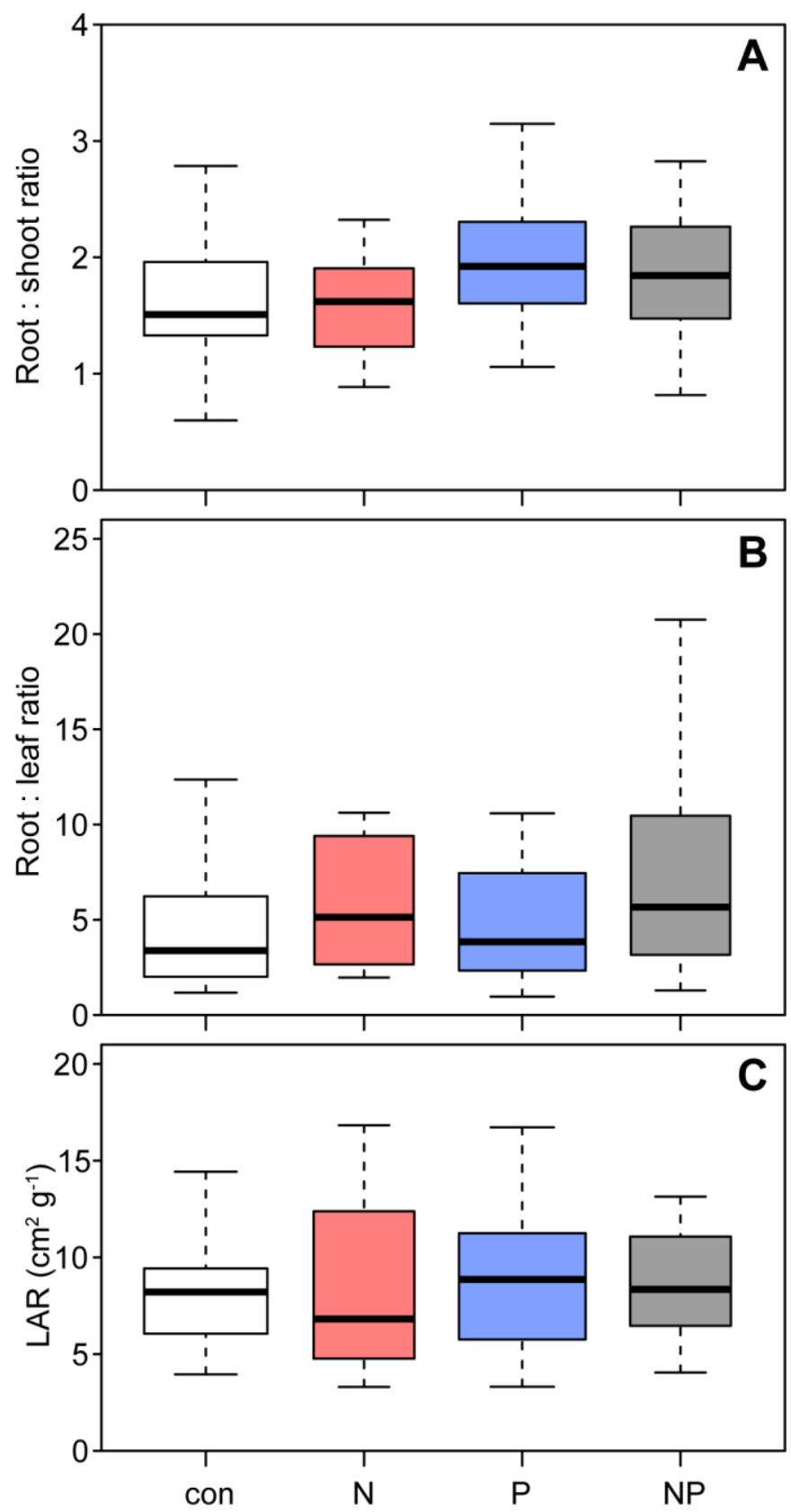

Figure 5.4 Effects of nutrient addition on the biomass allocation of Pouteria torta seedlings. (A) Changes in the root:shoot ratio indicate a shift in allocation towards the roots after $\mathrm{P}$ addition $(\mathrm{p}=0.003),(\mathrm{B}) \mathrm{N}$ addition increased the root:leaf ratio marginally $(\mathrm{p}=0.061),(\mathrm{C})$ but the leaf area ratio (LAR) was not affected. 
Table 5.2 Summary of the properties of surviving Pouteria torta seedlings after one year. The direction of significant effects (compared to the control treatment) is indicated (+/-) $\left({ }^{*} \mathrm{p} \leq 0.05 ; * * \mathrm{p} \leq 0.01\right)$.

\begin{tabular}{|c|c|c|c|c|c|c|c|}
\hline \multirow[b]{2}{*}{ Parameter } & \multicolumn{4}{|c|}{ Treatment } & \multicolumn{3}{|c|}{ Effect } \\
\hline & $\begin{array}{c}\text { Control } \\
\text { mean }(\mathrm{SE})\end{array}$ & $\begin{array}{c}\mathrm{N} \\
\text { mean }(\mathrm{SE})\end{array}$ & $\begin{array}{c}\mathrm{P} \\
\text { mean }(\mathrm{SE})\end{array}$ & $\begin{array}{c}\mathrm{N}+\mathrm{P} \\
\text { mean }(\mathrm{SE})\end{array}$ & $\mathbf{N}$ & $\mathbf{P}$ & $\mathbf{N} \times \mathbf{P}$ \\
\hline Mortality (\%) & $0.54(0.05)$ & $0.70(0.03)$ & $0.51(0.04)$ & $0.70(0.03)$ & $+^{*}$ & & \\
\hline Range of Mortality (\%) & $35-75$ & $60-80$ & $40-65$ & $60-85$ & & & \\
\hline $\operatorname{RGR}_{\mathrm{D}}\left(\mathrm{mm} \mathrm{mm} \mathrm{mr}^{-1} \mathrm{yr}^{-1}\right)$ & $0.23(0.02)$ & $0.39(0.02)$ & $0.34(0.03)$ & $0.37(0.03)$ & $+* *$ & $+*$ & $-*$ \\
\hline $\mathrm{LA}\left(\mathrm{cm}^{2}\right)$ & $\begin{array}{l}13.44 \\
(1.05)\end{array}$ & $\begin{array}{l}15.21 \\
(2.45)\end{array}$ & $\begin{array}{l}14.85 \\
(1.06)\end{array}$ & $\begin{array}{l}16.70 \\
(2.01)\end{array}$ & & & \\
\hline Leaf length ratio & $0.96(0.11)$ & $1.05(0.12)$ & $\begin{array}{l}0.85(0.08) \\
0.88\end{array}$ & $1.00(0.10)$ & & & \\
\hline Leaf width ratio & $0.99(0.13)$ & $1.15(0.14)$ & $(0.08)$ & $1.09(0.10)$ & $+*$ & & \\
\hline $\operatorname{SLA}\left(\mathrm{cm}^{2} \mathrm{~g}^{-1}\right)$ & $68.2(1.0)$ & $103.7(1.7)$ & $73.5(1.0)$ & $\begin{array}{l}100.3(1.6) \\
10.14\end{array}$ & $+* *$ & & \\
\hline Leaf area loss (\%) & $\begin{array}{l}5.16(0.87) \\
22.04\end{array}$ & $\begin{array}{l}4.87(1.03) \\
22.77\end{array}$ & $\begin{array}{l}8.88(1.85) \\
21.33\end{array}$ & $\begin{array}{l}(2.22) \\
22.90\end{array}$ & & $+*$ & \\
\hline Foliar $\mathrm{N}\left(\mathrm{mg} \mathrm{g}^{-1}\right)$ & $(0.63)$ & $(0.63)$ & $(0.50)$ & $(0.82)$ & & & \\
\hline Foliar P $\left(\mathrm{mg} \mathrm{g}^{-1}\right)$ & $1.44(0.08)$ & $1.39(0.11)$ & $1.41(0.08)$ & $1.39(0.10)$ & & & \\
\hline Foliar $\mathrm{N}\left(\mathrm{mg} \mathrm{cm}^{-2}\right)$ & $0.46(0.04)$ & $0.32(0.03)$ & $0.44(0.04)$ & $0.35(0.05)$ & $-* *$ & & \\
\hline Foliar P $\left(\mathrm{mg} \mathrm{cm}^{-2}\right)$ & $0.03(0.002)$ & $0.02(0.003)$ & $0.03(0.003)$ & $0.02(0.01)$ & $-* *$ & & \\
\hline $\begin{array}{l}\text { Foliar N (mg) per } \\
\text { seedling }\end{array}$ & $5.62(0.60)$ & $4.54(0.75)$ & $5.83(0.78)$ & $5.48(1.04)$ & & & \\
\hline $\begin{array}{l}\text { Foliar P (mg) per } \\
\text { seedling }\end{array}$ & $0.38(0.04)$ & $0.32(0.06)$ & $0.40(0.05)$ & $0.38(0.09)$ & & & \\
\hline Foliar N:P ratio & $\begin{array}{l}15.90 \\
(0.72) \\
22.62\end{array}$ & $\begin{array}{l}17.15 \\
(0.76) \\
21.69\end{array}$ & $\begin{array}{l}16.51 \\
(0.82) \\
23.55\end{array}$ & $\begin{array}{l}17.90 \\
(1.31) \\
21.73\end{array}$ & & & \\
\hline Foliar C:N ratio & $(0.61)$ & $(0.66)$ & $(0.53)$ & $(0.73)$ & $-*$ & & \\
\hline Total biomass (g) & $1.63(0.10)$ & $1.65(0.12)$ & $1.77(0.13)$ & $1.86(1.15)$ & & & \\
\hline LMF & $0.16(0.02)$ & $0.12(0.01)$ & $0.16(0.02)$ & $0.13(0.02)$ & $-*$ & & \\
\hline SMF & $0.32(0.01)$ & $0.35(0.01)$ & $0.29(0.02)$ & $0.32(0.02)$ & $+^{*}$ & $-* *$ & \\
\hline RMF & $0.51(0.02)$ & $0.53(0.02)$ & $0.55(0.02)$ & $0.56(0.01)$ & & $+*$ & \\
\hline Root : shoot ratio & $1.69(0.09)$ & $\begin{array}{l}1.58(0.08) \\
10.04\end{array}$ & $2.07(0.12)$ & $1.87(0.11)$ & & $+* *$ & \\
\hline Root : leaf ratio & $7.82(2.60)$ & $(2.66)$ & $6.98(1.22)$ & $7.87(1.54)$ & & & \\
\hline LAR & $8.38(0.62)$ & $8.95(1.17)$ & $8.95(0.61)$ & $9.62(0.77)$ & & & \\
\hline
\end{tabular}

\subsubsection{Leaf properties and herbivory}

Leaf properties are recognized as key traits in determining establishment and survival success of tree seedlings under varying site conditions and they are usually a good indicator of potential growth rates. There is a strong trade-off between high leaf lifespan, high leaf 
toughness, low herbivory and low mortality on the one hand, and high foliar nutrient concentrations and fast growth rates on the other hand (e.g., Wright et al., 2010; Kitajima et al., 2013; Philipson et al., 2014; Poorter \& Bongers, 2006).

We observed a strong positive effect of $\mathrm{N}$ addition on SLA. Other studies reported a higher SLA in tropical tree seedlings after P addition (e.g., Burslem et al., 1995: Antidesma cuspidatum in Singapore; Wan Juliana et al, 2009: Lagerstroemia floribunda in Malaysia) or found no effect of fertilization on SLA (Santiago et al., 2012: five shade-tolerant tree species). SLA is known to be a good predictor of growth rates in seedlings (Wright \& Westoby, 1999; 2000), so the increased growth rates in the $\mathrm{N}$ treatments are not surprising. Strong effects of herbivory in the $\mathrm{P}$ treatments were probably masking an even larger productivity stimulation by the nutrient addition (especially in the $\mathrm{N}+\mathrm{P}$ treatment, where herbivory and also SLA were significantly increased compared to the control); a similar masking of growth increase by herbivory was shown by Andersen et al. (2010) for different palm species after $\mathrm{N}$ addition. Increased leaf damage through herbivory after $\mathrm{P}$ addition was also reported by Santiago et al. (2012) in Panama where the proportion of herbivory in seedlings was higher after P or K addition. Werner and Homeier (2015) found a positive correlation of eaten leaf area with both foliar $\mathrm{N}$ and $\mathrm{P}$ concentrations in a montane forest close to our study site. All these studies show that herbivore choice is strongly driven by resource quality (i.e., nutrient content and palatability of leaves). Hence, herbivory can play a fundamental role in structuring seedling communities by directly affecting the survival of plants or mediating responses to soil nutrient availability (e.g., Barton \& Hanley, 2013; Andersen et al., 2010; Eichhorn et al., 2010).

Leaf tissue $\mathrm{N}: \mathrm{P}$ ratios of 15.9 in the control plots point at a balanced supply of both nutrients (Townsend et al., 2007) and after addition of N or P, Pouteria seedlings did not accumulate the respective nutrient in their leaves. This is contrary to the results of several studies that found an increase of foliar nutrient concentrations in shade-tolerant tree seedlings after fertilization (Burslem et al., 1995; Andersen et al., 2010; Santiago et al., 2012; Lawrence 2003). It appears that improved nutrient availability induced higher nutrient uptake only at a rate proportional to the increase in growth rate, resulting in a dilution of the added nutrients by carbon and fairly stable foliar nutrient concentrations. Furthermore, Pouteria seedlings may store the added nutrients in stems or roots as investment in long-term survival. 
Such a strategy of late-successional species was reported by Raaimakers \& Lambers (1996) for Lecythis corrugata seedlings in Guyana.

\subsubsection{Biomass allocation}

The high root mass fraction of Pouteria seedlings compared to other shade-tolerant tropical tree seedlings (Burslem et al., 1995; Wan Juliana et al., 2009; Huante et al., 1995a) could be explained as an adaptation to generally low nutrient availability at the study site, as was shown for our study site by the stimulation of tree root growth after $\mathrm{N}$ and $\mathrm{P}$ (and also K) addition in the ingrowth core experiment of Graefe et al. (2010). These results indicate that trees put a high priority on the maximization of belowground resource acquisition at this site, as also reported by Paz (2003) and Poorter et al. (2012) for other tropical forests.

Upon nutrient addition, we expected a compensatory change in carbon allocation to aboveground tissues as a result of increased soil nutrient availability (e.g., Marschner, 1995; Poorter et al., 2012). Surprisingly, SMF was reduced and the root:shoot ratio increased after $P$ addition, and the root:leaf ratio was higher after $\mathrm{N}$ addition. In addition, LAR was not affected by nutrient addition. Enhanced $\mathrm{C}$ allocation to roots in a shade-tolerant species suggests that carbon and other elements are mainly stored in belowground organs to improve seedling survival under the very low light intensity at the forest floor of this stand (Raaimakers \& Lambers, 1996).

\subsection{Conclusion}

Foliar nutrient concentrations are apparently not a good indicator of nutrient limitation in the rainforest tree Pouteria torta, since nutrient addition did not change the N/P concentrations or the ratio of the two nutrients. The species' high abundance in the forests is another indication that it is well-adapted to the current growing conditions at this site. Nevertheless, this shade-tolerant species was capable of responding to improved nutrient supply with higher seedling growth rates, if the plants were able to survive in the relatively dark and nutrient-poor environment. On the population level, however, it is difficult to make predictions on how a future increase in nutrient deposition will change the recruitment success of this species, because individual growth increases are coupled with increased herbivory and higher mortality. In any case, the moderate addition of $50 \mathrm{~kg} \mathrm{~N}$ ha $^{-1}$ and $10 \mathrm{~kg}$ 
Chapter 5

$\mathrm{P} \mathrm{ha}{ }^{-1}$ provoked a number of morphological and physiological responses that will likely alter the performance of this common tree species and will have consequences for competition with other tree species. In further studies it would be interesting to investigate whether the cooccurring tree species respond similarly to $\mathrm{N}$ and $\mathrm{P}$ addition or if currently less abundant species gain competitive strength, thus indicating potential changes in the composition of future forests under increased nutrient deposition.

\subsection{Supplementary information}
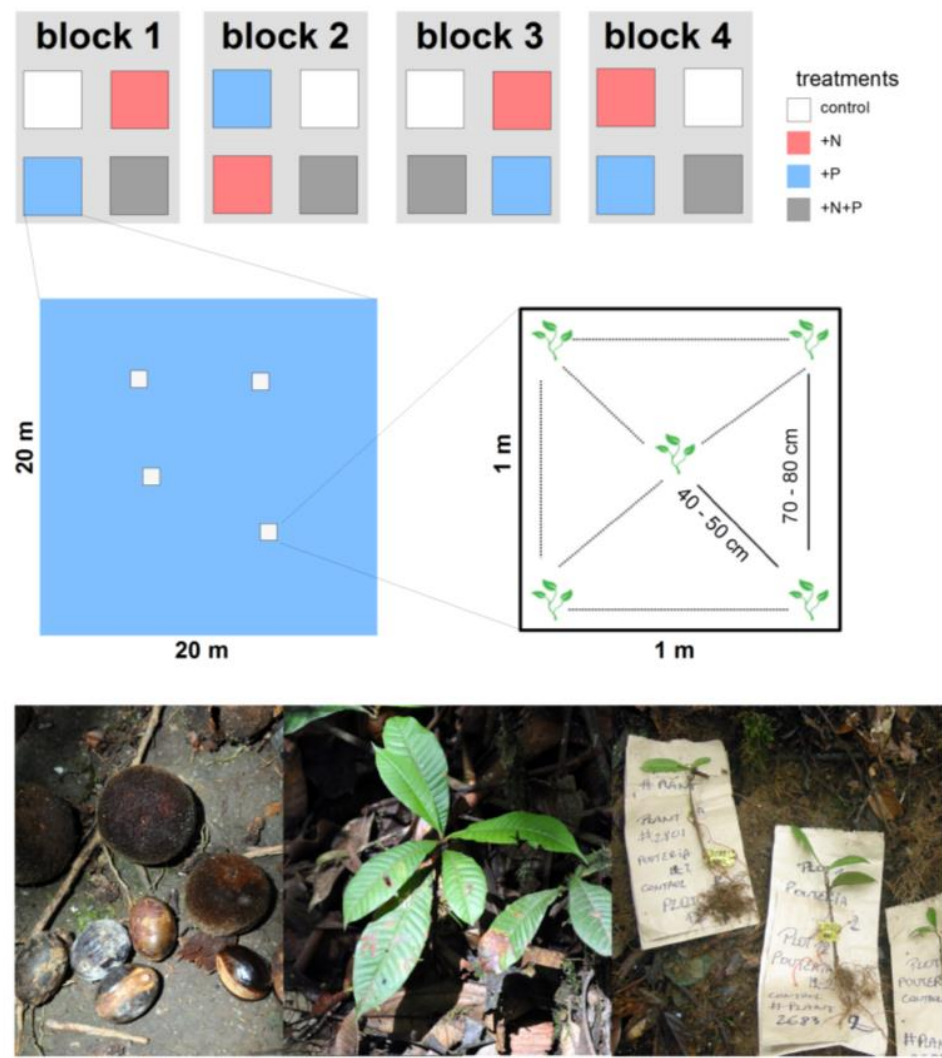

Figure S5.1 Nutrient manipulation experiment (NUMEX) and seedling study design. Above: Schematic overview of the experimental design. The two-factorial block design of the Ecuadorian Nutrient Manipulation Experiment (NUMEX) includes four blocks placed in old-growth forest, each including one 20 x $20 \mathrm{~m}$ plot per treatment (control, $\mathrm{N}$-addition, $\mathrm{P}$-addition, both nutrients). One plot is shown in detail to illustrate the additional four randomly assigned seedling subplots $(1 \times 1 \mathrm{~m})$. Each seedling plot was planted with five Pouteria torta seedlings as illustrated. Below: Fruits and seeds, naturally established seedlings in a control plot and some of the harvested seedlings of Pouteria torta. 
Table S5.1 Soil biochemical characteristics in top 5-cm of mineral soil of the Numex plots at $1000 \mathrm{~m}$, measured in April 2012 after 4 years of treatment, data from Baldos et al. (2015). Treatments do not differ significantly in the shown properties.

\begin{tabular}{lcccc}
\hline \hline Soil properties & Control & $\mathbf{N}$ & $\mathbf{P}$ & $\mathbf{N}+\mathbf{P}$ \\
\hline $\mathrm{pH}\left(\mathrm{H}_{2} \mathrm{O}\right)$ & $4.3(0.2)$ & $3.9(0.2)$ & $4.3(0.2)$ & $3.8(0.2)$ \\
Total N $\left(\mathrm{g} \mathrm{N} / \mathrm{m}^{2}\right)$ & $168(35)$ & $172(27)$ & $139(13)$ & $181(35)$ \\
Total N $(\mathrm{mg} / \mathrm{g})$ & $3.99(0.82)$ & $4.09(1.36)$ & $3.32(0.34)$ & $4.32(1.01)$ \\
C:N ratio & $14(1)$ & $14(1)$ & $14(1)$ & $13(2)$ \\
\hline \hline
\end{tabular}

Table S5.2 Structure of the used statistical models.

\begin{tabular}{|c|c|c|c|c|c|c|}
\hline Parameter & data & distribution & transformation & model & $\begin{array}{l}\text { fixed } \\
\text { effects }\end{array}$ & $\begin{array}{c}\text { random } \\
\text { factor }\end{array}$ \\
\hline Mortality & $\begin{array}{l}\text { subplot } \\
\text { counts }\end{array}$ & binomial & none & glmm & $\mathrm{N} * \mathrm{P}$ & block \\
\hline $\mathrm{RGR}_{\mathrm{D}}$ & individuals & normal & $\log$ & lme & $\mathrm{N} * \mathrm{P}$ & block \\
\hline $\mathrm{RGR}_{\mathrm{L}}$ & individuals & normal & $\log$ & lme & $\mathrm{N} * \mathrm{P}$ & block \\
\hline LA & individuals & normal & $\log$ & lme & $\mathrm{N} * \mathrm{P}$ & block \\
\hline Leaf length ratio & individuals & normal & $\log$ & lme & $\mathrm{N} * \mathrm{P}$ & block \\
\hline Leaf width ratio & individuals & normal & $\log$ & lme & $\mathrm{N} * \mathrm{P}$ & block \\
\hline SLA & individuals & normal & $\log$ & lme & $\mathrm{N} * \mathrm{P}$ & block \\
\hline Leaf area loss & individuals & normal & sqrt & lme & $\mathrm{N} * \mathrm{P}$ & block \\
\hline Foliar N & individuals & normal & $\log$ & lme & $\mathrm{N} * \mathrm{P}$ & block \\
\hline Foliar P & individuals & normal & $\log$ & lme & $\mathrm{N} * \mathrm{P}$ & block \\
\hline Foliar $\mathrm{N}$ mass basis & individuals & normal & $\log$ & lme & $\mathrm{N} * \mathrm{P}$ & block \\
\hline Foliar P mass basis & individuals & normal & $\log$ & lme & $\mathrm{N} * \mathrm{P}$ & block \\
\hline Foliar N:P ratio & individuals & normal & $\log$ & lme & $\mathrm{N} * \mathrm{P}$ & block \\
\hline Foliar C:N ratio & individuals & normal & $\log$ & lme & $\mathrm{N} * \mathrm{P}$ & block \\
\hline Total biomass & individuals & normal & sqrt & lme & $\mathrm{N} * \mathrm{P}$ & block \\
\hline LMF & individuals & normal & sqrt & lme & $\mathrm{N} * \mathrm{P}$ & block \\
\hline SMF & individuals & normal & none & lme & $\mathrm{N} * \mathrm{P}$ & block \\
\hline RMF & individuals & normal & none & lme & $\mathrm{N} * \mathrm{P}$ & block \\
\hline Root : Shoot ratio & individuals & normal & $\log$ & lme & $\mathrm{N} * \mathrm{P}$ & block \\
\hline Root : leaf ratio & individuals & normal & $\log$ & lme & $\mathrm{N} * \mathrm{P}$ & block \\
\hline LAR & individuals & normal & $\operatorname{logit}$ & lme & $\mathrm{N} * \mathrm{P}$ & block \\
\hline
\end{tabular}




\section{Chapter \\ 6}

GENERAL DISCUSSION 


\subsection{Introduction}

This study tested how natural regeneration of tropical montane forest seedlings responded to changes in soil characteristics, resulting from the long-term addition of moderate amounts of fertilizer to experimental plots distributed across an elevational range. Three years of monitoring and experimental data in situ were recorded, and the resulting data were used to address hypotheses concerning the effects of fertilization on seedling community dynamics (Chapter 3) and the specific responses of common species to fertilization (Chapter 4 and Chapter 5). Here, I will first summarize the most important results and conclusions from each chapter. Second, I will review the literature on seedling fertilization experiments. Third, I will contrast the findings of the present study with other fertilization experiments conducted in tropical forests. Finally, I will discuss the final conclusion of this study and highlight some productive avenues for future research.

\subsection{Summary of main results and conclusions}

In Chapter 3, the community response of seedlings to moderate fertilization was analyzed. Community analyses were divided into two relevant groups (common and rare species) with the aim to determine which group was more representative of the seedling dynamics in the whole community. Changes in the density of one of these groups would represent significant changes in seedlings by altering recruitment, mortality and growth rates.

Using linear mixed models, I modelled seedling density, recruitment, survival, and species richness as a function of fertilization to determine responses in seedlings assemblages. Additionally, I analyzed the relative growth rate of height growth (RGRh), leaf production (RGRl), height, and herbivory with the aim to determine the main drivers of survival and mortality of individual seedlings after fertilization.

Responses at the community level were moderate and suggested that $\mathrm{N}$ and $\mathrm{P}$ might co-limit regeneration at the $2000 \mathrm{~m}$ site, as has been postulated in several prior investigations in montane forests (Tanner et al., 1990; 1992; 1998; Cavelier et al., 2000; Wolf et al., 2011). Significant negative responses (e.g., reduced in seedling densities) to $\mathrm{N}$ addition were manifested in the $\mathrm{N}+\mathrm{P}$ treatment in both the common and rare species groups but not for all 
seedlings species together (although total seedling density increased from 2011 - 2013). The negative community response of recruitment to $\mathrm{N}$ was largely driven by rare species. I observed large inter-annual variation in seedling density at $2000 \mathrm{~m}$, which is likely a strategy used by many species to ensure persistence over changeable climatic conditions (Tunner, 2001; Metz et al., 2008; Bendix et al., 2006). Contrary to the main expectations of this study, I found a decrease in seedling density in nutrient-treated plots, which suggested that any density-dependent pressure would alter species assemblages in this case.

Seedling survival did not appear to be affected by nutrient addition at the community level. The negative effects of fertilization on survival observed in common species might have been caused by other factors such as herbivory (Eichhorn et al., 2010) or biotic factors close related (e.g., parental trees and root pathogens), which reduced the competitive strength of individual common species.

Significant height increases were observed in seedlings, although average height decreased over the study due to the increasing number of newly recruited seedlings in the common species group every year (Table 3.1). Rare species showed significant higher differences in height as a response of $\mathrm{N}$ addition, which might have been partly influenced by the lower recruitment rates in this species group (Figure 3.2). Height growth did not vary significantly at the community level between the two parallel groups, contrary to the results that Alvarez-Clare (2013) showed for Costa Rica (the percentage of growing seedlings increased after P addition) and Wright et al. (2011) showed for Panama (seedlings responded to addition of $\mathrm{N}+\mathrm{K}$ but $\mathrm{P}$ had no effects).

Seedling herbivory increased with $\mathrm{N}$ addition every year, although it was not affected by other soil nutrients or light. This result was expected for such nutrient-poor soils. Nonetheless, similar studies in lowland forests have found equivocal results. Santiago et al (2012: BCI, Panama) found that an interaction of P + K increased the level of leaf damage in a pooled common species analysis, but Eichhorn et al. (2006: Sepilok, Sabah) found no effect of complete fertilizer $(\mathrm{N}+\mathrm{P}+\mathrm{K}+\mathrm{Mg})$ on seedling herbivory.

Since no effects of fertilization on survival and growth were found, this indicated that herbivory rates might affect habitat partitioning at this site (Fine et al., 2004; Eichhorn et al., 2006) and the increase in herbivory perhaps masked positive growth responses to elevated 
nutrient supply as suggested by Andersen et al., (2010) and Santiago et al., (2012) for lowland tropical forest.

Changes in species richness might be $\mathrm{N}$ mediated via changes in soil properties such as low $\mathrm{pH}$, leaching of cations, and $\mathrm{N}$ mobility. In San Francisco, species richness decreased in all treatments among years, but this was only significantly lower in $\mathrm{N}$ addition in 2013, perhaps due to few species recruiting that year. I suggested that changes in the structure of the forest are slow so far, although some mechanisms did respond to the fertilization. Therefore, I expected stronger effects in seedling dynamics would take place over a longer time, when soil reaches a saturation of $\mathrm{N}$ or/and $\mathrm{P}$.

In Chapter 4, I made complementary comparisons among the six most common species along the elevational gradient. This approach aimed to determine specific responses in morphology attributes and biomass allocation patterns of seedlings growing in the NUMEX experimental plots, which were not monitored as part of the seedling community censuses at every altitude. I conducted comparisons of morphological leaf traits (i.e., SLA, LAR, LA, and herbivore), foliar nutrient content (including nutrient ratios) and differences of biomass allocation. The main objective in this study was to determine to what extent common species show plasticity in adaptation to moderate changes in nutrient supply. Additionally, I wanted to test whether more adapted species (common species) are more responsive to predicted nutrient limitations of the altitudinal range (i.e., limitation of P at 1000 and $2000 \mathrm{~m}$; limitation of $\mathrm{N}$ at $3000 \mathrm{~m}$ ).

The following common shade tolerant species were chosen: at $1000 \mathrm{~m}$ (Bombuscaro), Clarisia racemosa and Pouteria torta; at $2000 \mathrm{~m}$ (San Francisco), Graffenrieda emarginata and Palicourea angustifolia; at $3000 \mathrm{~m}$ (Cajanuma), Graffenrieda harlingii and Hedyosmum purpuracens. Approximately twenty individuals of each species were harvested in every experimental plot (Figure 2.8).

In general, all species showed a skewed limitation to $\mathrm{P}$ which was evident in the high $\mathrm{N}: \mathrm{P}$ ratios (values $>16$ ) in all species (Figure 4.4). Seedlings of species at $3000 \mathrm{~m}$ exhibited the strongest effects among treatments. No evidence of an exclusive limitation related to the altitudinal range was found, but rather every species responded differently individually to $\mathrm{N}$ and $\mathrm{P}$, suggesting an interspecific variation in nutrient uptake and use (Figure 4.1). In nutrient-poor soils, species coexistence is facilitated due to the fact that competition for a low 
mobility resource like $\mathrm{P}$ might be weaker than for a high mobility one like $\mathrm{N}$ (Güsewell, 2004). Thus, my results may indicate a balance of interspecific competition among species responding to $\mathrm{P}$.

Only $P$. torta responses were neutral, suggesting that there is a unique preference to assimilate additional nutrients according to availability. The results in Chapter 5 demonstrated that, indeed, Pouteria torta shows a particular response to changes in soil nutrient concentrations.

Morphological leaf attributes changed moderately in all species and showed varied responses to nutrient concentrations (Figure 4.1, Table 4.2), which is contrary to my initial hypotheses. Nevertheless, other studies in tropical tree species anticipated that no correlation between nutrient concentration and leaf morphology changes might be explained by a colimitation of nutrients (Lawrence, 2001; Bracken et al., 2014; Elser et al., 2007) or by synergetic interactions among species adaptability traits.

Seedlings need to acquire resources to support the physiological functions of growth, survival and defense (Kitajima, 1996; Boege, 2005) and to compete for scarce light in the understory (Yavitt, 2008). If other resources are not limiting, seedlings will benefit from photosynthetic rates changing proportionally with leaf $\mathrm{N}$ concentration (Field \& Mooney, 1986). Therefore, assuming changes in leaf areas are directly caused by nutrient limitation might not be an accurate interpretation. Responses in morphological changes in leaf areas were contradictory. For instance, $C$. racemosa exhibited higher SLA responding to $\mathrm{N}+\mathrm{P}$ contrary to $P$. torta (at the same elevation) which showed smaller leaves in $\mathrm{P}$ treatment (Figure 4.1). Leaf areas in G.harlingii seemed to be affected by $\mathrm{N}$ addition whereas leaves in $H$. purpuracens mainly responded to $\mathrm{P}$ at $3000 \mathrm{~m}$ suggesting different mechanisms of adaptation to resources at the same altitude.

Addition of $\mathrm{N}$ to soil resulted in significantly higher $\mathrm{N}$ in foliar tissues of three species in the altitudinal range (C. racemosa, $1000 \mathrm{~m}$; G. emarginata, $2000 \mathrm{~m}$; G. harlingii, $3000 \mathrm{~m}$ ) but contrary to my expectations, no other significant morphological changes were associated with higher N (Figure 4.3). In addition, G. emarginata showed significant N concentration in $\mathrm{P}$ treatments, which was a unique particular mechanism similar to the one described by Tresender \& Vitousek (2001). This response is attributed to the fact that $\mathrm{N}$ might alleviate $\mathrm{P}$ limitation by providing enough substrate to construct extracellular 
phosphatase to acquire P. Consequently, the results observed in this study might indicate that physiological processes to acquire $\mathrm{N}$ or $\mathrm{P}$ may be promoted by additional nutrient availability in this species.

Four of the six species allocated more that $40 \%$ of the biomass to roots indicating that these species prioritize maximization of belowground resource acquisition. A similar pattern was reported by Poorter et al. (2012) and Paz (2003) in other tropical forests. However, this strategy could be interpreted as an adaptation to the generally low nutrient availability, as it was reported by the stimulation of tree root growth upon nutrient addition on the ingrowth core experiment of Graefe et al. (2010). In the case of G. emarginata and Hedyosmum, because they showed the smallest root fractions in the gradient, they seem to be more efficient in nutrient acquisition under the control conditions. This might be related to their mycorrhizal status; G. emarginata has a dual colonization by AMF and ectomycorrhizae (Kottke et al., 2004; Haung et al., 2004) whereas Hedyosmum has the highest colonization rate by AMF. Among the studied species, other symbiotic associations have been described only in adult trees of C. racemosa (Homeier, unpublished data).

Impacts of herbivory were low and resulted in less than $10 \%$ of leaf area loss in all species. Only two species showed leaf area loss that may be associated with nutrient addition: G. emarginata had significantly higher herbivory in $\mathrm{N}$ and $\mathrm{N}+\mathrm{P}$ treatments and $P$. angustifolia had higher herbivory in P treatments (Figure 4.3). It is well known that even minimal herbivory can be harmful for seedling performance. So, these effects are not directly related with the area damaged but might be detrimental by modifying photosynthetic balance and retarding growth (Eichhorn et al., 2010; Zanger et al., 2001). Increased herbivory is also associated with high foliar N concentration (Eichorn et al., 2000; Campo \& Dirzo, 2003) since $\mathrm{N}$ results in better palatability of foliar tissues (Andersen et al., 2010) and thus has higher attraction for predators. In this study not all species with higher $\mathrm{N}$ concentration suffered highest herbivory. Herbivory caused by $\mathrm{P}$ accumulation in leaf tissues is still not well known for seedlings since P is relatively immobile in soils (Tresender \& Vitousek, 2001), although few studies showed that an increase of herbivory produced by other nutrients could be possible in the tropics (Santiago et al., 2012; Werner \& Homeier, 2015).

Different mechanisms of biomass allocation were observed among common species in the altitudinal gradient (Figure 4.5). In the most N-rich soil at $1000 \mathrm{~m}$, Bombuscaro, $C$. 
racemosa and $P$. torta showed higher biomass accumulation located belowground but these differences were not significant. Shoot fractions were higher in $\mathrm{P}$ fertilization plots in P. torta but lower in $C$. racemosa. Allocation in shoots is explained as the result of carbohydrate deficiencies as a consequence of reduced sugar export from chloroplasts to the cytosol (Ericsson, 1995; Huante et al., 1995b). In San Francisco, neither of the species showed big differences in root:shoot ratios (Figure 4.6) although it is evident that biomass is accumulated aboveground. G. emarginata shoot fractions were significantly higher in all treatments compared with controls, although shoots had low levels of both $\mathrm{N}$ and $\mathrm{P}$ after fertilization (Figure 4.6). Species in Cajanuma showed much more allocation to above-ground biomass after fertilization. In $G$. harlingii, leaf fractions showed that nutrient transport may be facilitated equally as described in species that showed co-limitation of nutrients (Bracken et al., 2004). Additionally, root:shoot ratios in H. purpuracens were higher in the leaf fraction and significant lower after $\mathrm{N}$ addition (Figure 4.5). In both species, $\mathrm{N}$ seems trigger more allocation to leaf biomass.

Successful species in poor soils normally have functional mechanisms for the acquisition of $\mathrm{N}$ or $\mathrm{P}$ to become dominant and show a particular plasticity to adapt to resource availability. Those mechanisms do not always constitute specific adaptations but their expression depends on the availability of $\mathrm{N}$ or $\mathrm{P}$ (Güsewell, 2004). In the altitudinal gradient, species specific resources requirement were observed by changes in morphological and chemical attributes which did not respond according to the initial predictions.

In Chapter 5, I analyzed a particular case of species-specific responses to moderate nutrient addition, showing the results of the first seedling transplantation experiment conducted in a pre-montane forest, Bombuscaro (Cárate Tandalla et al., 2015).

Using Pouteria torta (Sapotaceae), a locally abundant late-successional species, I transplanted seedlings of the same age to NUMEX subplots from the surrounding forest, eliminating aboveground competition. After 10 months, I harvested the seedlings and analyzed leaf traits, biomass allocation, herbivory and nutrient concentration and ratios in response to the nutrient addition.

Initial seedling mortality in $P$. torta after transplanting was high, even up to $70 \%$ in the $\mathrm{N}$ addition treatments (Figure 5.1). In seedling transplantation experiments, high mortality is commonly observed in the first months after setting up the experiment (Alvarez-Clare \& 
Kitajima, 2009; Brenes-Arguedas et al., 2011; Eichhorn et al., 2006). This high mortality is mainly related to the robustness of seedlings to the transplant process and the conditions of their new site (Kitajima, 2000; Alvarez-Clare \& Kitajima, 2007). After 4 years of experimental fertilization, changes in soil $\mathrm{pH}$ could have been sufficient to drive high mortality (Table 5.2.), but this was not the case for the soils in Bombuscaro (Baldos et al., 2015). The transplanted seedlings should have been robust enough to survive transplantation (i.e., they were about 6 months old), but the high mortality indicates that there was still some degree of fragility and they did not adapt easily to a new substrate.

Seedling growth is the sum of responses to complex interactions in the local neighborhood of each individual. In this case, diameter growth $\left(\mathrm{RGR}_{\mathrm{D}}\right)$ increased $30-50 \%$ in $\mathrm{N}$ and $\mathrm{P}$ treatments compared to controls for the surviving seedlings (Figure 5.2). $\mathrm{N}$ and $\mathrm{P}$ are essential for photosynthesis, since the Rubisco protein accounts for ca. $30 \%$ of leaf $\mathrm{N}$ and $\mathrm{P}$ and play a vital role in membrane solubility, ATP, and NADPH production (Walker et al., 2014). Since there was not an increase of $N$ or $P$ concentrations with the increase of $40 \%$ in SLA (Figure 5.3a; Table 5.2), I could not assume higher photosynthetic rates might cause higher productivity as previous studies have suggested (Pasquini \& Santiago, 2012 for Alseis blackniana). On the contrary, the increase in leaf area (LA, no significantly response to $\mathrm{N}$ and $\mathrm{N}+\mathrm{P}$ ) in this case may have led to higher productivity after fertilization.

Increases in SLA are known to be a good predictor of growth rates for seedlings (Wright \& Westoby, 1999; 2000), so a positive response of SLA to N addition is not surprising. Contrary to my initial hypothesis, seedlings growing in $\mathrm{P}$ and $\mathrm{N}+\mathrm{P}$ treatments showed a significant leaf area loss, indicating P-mediated herbivory (Figure 5.3b). Herbivory can play a fundamental role in structuring seedling communities, both directly affecting plant survival as well as mediating responses to soil nutrient availability (Barton \& Hanley, 2003; Andersen et al., 2010; Eichhorn et al., 2010). The strong effect of herbivory probably masked larger biomass productivity by seedlings in nutrient addition treatments (especially in $\mathrm{N}+\mathrm{P}$, where herbivory and also SLA were significantly increased compared to the control). Similar patterns of masking productivity were found in Andersen et al. (2010) in different palm species in response to $\mathrm{N}$ addition, but only Santiago et al. (2012) found a similar response in terms of high herbivory after $\mathrm{P}$ addition. Foliar $\mathrm{N}$ and $\mathrm{P}$ concentrations after 10 months were not significantly different (Figure 5.3c; Table 5.2). I expected an accumulation of $\mathrm{N}$ in leaf tissues, as has been observed in several studies in tropical forests (Burslem et al., 1995; 
Chapter 6

Andersen et al., 2010; Santiago et al., 2012) but it did not ocurre. It seems, for Pouteria torta, that improved nutrient availability induced higher nutrient uptake only at a rate proportional to the increase of growth rate, causing a dilution of the extra nutrients by carbon and stable foliar nutrient concentrations. The ratio of $\mathrm{N}$ to $\mathrm{P}$ varied between 15.9 in the control treatment to 17.9 in the $\mathrm{N}+\mathrm{P}$ treatment (Figure 5.3c), indicating no limitation either for $\mathrm{N}$ or $\mathrm{P}$ since control values showed a balanced supply of both nutrients (Townsend et al., 2007).

We observed that $\mathrm{P}$ addition shifted a high root mass fraction (Figure 5.4a, $\mathrm{b}$ ) in this shadetolerant species which might be explained as an adaptation to generally low nutrient availability at the $1000 \mathrm{~m}$ study site as it was proven by previous experiments conducted by Graefe et al., (2010) in mature trees. Graefe et al., demonstrated that the addition of $\mathrm{N}$ and $\mathrm{P}$ (and $\mathrm{K}$ ) caused trees to put a higher priority on maximizing belowground resource acquisition (e.g., Paz, 2003; Poorter et al., 2012). In such cases, given the increase in nutrient supply, a compensatory carbon allocation aboveground is also expected. However, for Pouteria torta neither shoot mass fraction nor leaf mass fraction indicated a significant increase after $\mathrm{N}$ or $\mathrm{P}$ addition (Table 5.2, Figure 5.4b). In this case, $\mathrm{C}$ allocation might be mainly stored in belowground organs and used later to improve seedling survival under low light environments (Raaimakers \& Lambers, 1996).

\subsection{Effects of nutrient addition on tropical tree seedlings}

In this section, I address the state of knowledge concerning the effects of nutrient availability on the survival and growth of seedlings and therefore establishment and recruitment of tree species in tropical forests. One extensive meta-analysis summarized the literature up until 2003 (Lawrence, 2003). I will extend this to include the results of 49 experiments published in 36 references from 1987 to August 2015, including the present study (Table 6.1).

Studies of successional dynamics (including natural regeneration) have shown highly conflicting results (Norden et al., 2015), mainly attributed to the divergence in inter- and intra-specific variability and spatio-temporal dynamics of species recruitment and demography. Fertilization experiments have been conducted in many cases in fragmented tropical ecosystems (Ceccon et. at, 2003; 2004; Campo \& Dirzo, 2003) to assess mechanisms 
of natural succession after decades of intensive land use. Additionally, studies aimed to find out how nutrient addition to soils would facilitate long term succession in primary forests. In recent decades, fertilization experiments have also been conducted in order to determine changes in the performance of ecologically distinctive seedlings adapted to different resources (i.e., light, leaf litter, water). Most of these studie used target species classified by their tolerance to light availability (i.e., shade-tolerant versus light-demanding species); and hypothesized particular responses based on these life history strategies attributes to their habitat (Kitajima et al., 2000; Kitajima, 2010). Thus, among 36 references reviewed for this dissertation three main approaches have been used to assess specific responses to variation in nutrient availability. The differences and main conclusions from these approaches are summarized below.

\subsubsection{Experimental approaches}

\section{"Pot Experiments"}

Growing seedlings in experimental pots allows for control of abiotic factors (i.e., light, water, nutrients) as well as the local biotic neighbourhood of each seedling to control potential competition. Most pot experiments varied either the percentage of light intensity (e.g., Thompson et al., 1992; Bungard et al., 2000), quantity of irrigation (e.g., Lawrence, 2001; Baraloto et al., 2006), litter presence (e.g., Vincent et al., 2013) or various nutrients in combination with other abiotic factors (e.g., Denslow et al., 1987; 1990; Burslem et al., 1994). The elimination of belowground competition is achieved in these studies by sieving and cleaning soils before sowing the seeds. In most cases, doses of nutrients provided to seedlings were small and fertilization was done together with irrigation during short (from 23 months) and long (in this review, a maximum of two years) experiments. The growth and biomass allocation responses to fertilization were directly observed in seedlings and didn't require extensive analyses. However, the general applicability of pot experiments is limited because of lack of natural interactions of seedlings with their local biotic and abiotic neighbourhood. Interpretation of these results requires complementary information in order to evaluate the responses of seedlings in the real environmental conditions of tropical forests. 
Chapter 6

\section{"Seedling Transplantation Experiments"}

Reciprocal transplantation experiments (seedling transplantation experiments) try to determine responses of seedling dynamics to variation in nutrient availability in the absence of interspecific competition by the consideration of mainly belowground factors. The standard procedure consists of germinating seedlings separately in neutral soils and, after a minimum period of establishment (e.g., 2-9 months), moving them to bags in nurturing houses. Subsequently, seedling transplantation and fertilization takes place in plots using higher amounts of nutrients (mainly, N, P, Ca, K and combinations) than the "normal" quantity of nutrients in forests (i.e., $>100 \mathrm{~kg} \mathrm{ha}^{-1}$ of $\mathrm{N},>50 \mathrm{~kg} \mathrm{ha}^{-1}$ of P). Many experiments of reciprocal transplantation evaluate natural light availability by setting up plots under or near forest gaps, or under various degrees of canopy openness (e.g., Fetcher et al., 1996; Eichhorn et al., 2006 and 2010). In this revision of bibliographic material, I found that many studies including reciprocal transplant used well-determined light-demanding and shadetolerant tree species. Assessments have also considered variation in interactions of soil elements as well as litter accumulation (e.g., Vincent et al., 2013), dung (e.g., Nussbaum et al., 1995), and soil type (e.g., Palmiotto et al., 2004) to examine particular preferences in adaptability to different soils. Transplant experiments generate more complex information than pot experiments over a relatively short term (6-42 months). The analyses of these experiments show assessments of growth rate, biomass allocation patterns, leaf morphology, herbivory (Cárate-Tandalla et al., Chapter 4 and 5), and even use efficiency of main nutrients ( $\mathrm{N}$ and/or $\mathrm{P})$.

\section{"Seedling Monitoring Experiments"}

Monitoring seedling responses to fertilization in situ provides the most complex panorama of seedling dynamics and demography but it requires more extensive monitoring areas, effort and time. Generally, most of the experiments required long-term observations in the field (2-10 years) and periodic measurement of attributes such as: height, diameter, leaf production and damage, and mortality in target species (i.e., normally, common or abundant species). Fully factorial arrangements of plots and treatments are ideal to evaluate abiotic variation in factors such as light, soil moisture, nutrient content, temperature, or irradiation (e.g., Turner et al., 1993; Campo \& Dirzo, 2003; Ceccon et al., 2003 and 2004; Cárate- 
Tandalla, et al., Chapter 3). Long-term assessments have focused on community responses using experimental treatments to determine the future changes in species composition, driven by high or low seedling recruitment, mortality, and survival (e.g., Raaimakers \& Lamber, 1996; Santiago et al., 2012; Schreeg et al., 2014; Salinas-Peba et al., 20013; Cárate-Tandalla et al., Chapter 3). Additionally, changes in species richness and diversity over time (Ceccon et al, 2004; Cárate-Tandalla, Chapter 3), annual growth effects (e.g., Turner et al., 1993; Santiago et al., 2012; Schreeg et al., 2014), and changes in nutrient concentration in seedlings (e.g., Schreeg et al., 2014; Cárate-Tandalla et al., Chapter 4) are evaluated. Community-level experiments have tended to produce muted effects of nutrient addition in many cases (e.g., Alvarez-Clare et al., 2013; Andersen et al., 2010) due to the numerous different interactions of individual species-level responses that might dampen the average community-level signal.

\subsubsection{Contrasting Seedlings responses}

\section{Community vs. Species Responses}

For years, tropical forests have been expected to be P-limited due to the fact that soils are assumed to be rich in available $\mathrm{N}$ through decomposition of litter increasing $\mathrm{N}$ availability in the topsoil, and taking into account that tropical forests grow on old soils. A main hypothesis made by Townsend (2008) is that $\mathrm{N}$ availability decreases with elevation in tropical forests. Therefore, many experimental studies expect species to respond according to the degree of limitation. Nonetheless, after many fertilization experiments (Table 6.1), a wide variety of positive and negative responses were found. The results of many of these studies have been summarized in a meta-analysis published by Lawrence (2003) but are also considered in this revision.

Studies at the community level (Table 6.1: references 10, 17 and 34) have mainly shown moderate responses of seedlings to fertilization. Responses indicated neither a general effect modifying all seedling assemblages nor a direct association with $\mathrm{N}$ or $\mathrm{P}$ by type of forest or elevation.

Indeed, multiple resource limitation at the community level may be likely (e.g., Turner et al., 1998) due to the number of interactions among species of plants, fungi, mycorrhiza and other organisms. Community seedling responses integrate over multiple 
nutrients and other abiotic and biotic factors as I summarized in Figure 6.1. Consequently, species communities may not be limited by only one nutrient. For instance, Ceccon et al. (2004) found that factors such as light availability and soil bulk properties, in addition to nutrients, interacted to determine seedling survival (Table 6.1: 10).

In general, effects of fertilization in studies of species communities not often found strong or dramatic effects working out in the same way in seedlings' growth and survival around all species. Three studies from the 36 publications reviewed in this chapter suggested that community effects masked individual species effects in seedlings since there is not a general strategy to overcome additional doses of nutrient availability among species. Recently, Bracken et al. (2014) suggested that tropical forests experience a compensatory relationship between nutrients and plants, so that a co-limitation of $\mathrm{N}$ and $\mathrm{P}$ may be the rule in these forests. However, another study found neither a specific limitation nor a co-limitation of nutrients in species from the Fortuna Forest in Panama where plants responded weakly to soil nutrients and light availability (Andersen et al., 2014). In this case, weak or neutral responses were attributed to an intermediate nutrient fertility level.

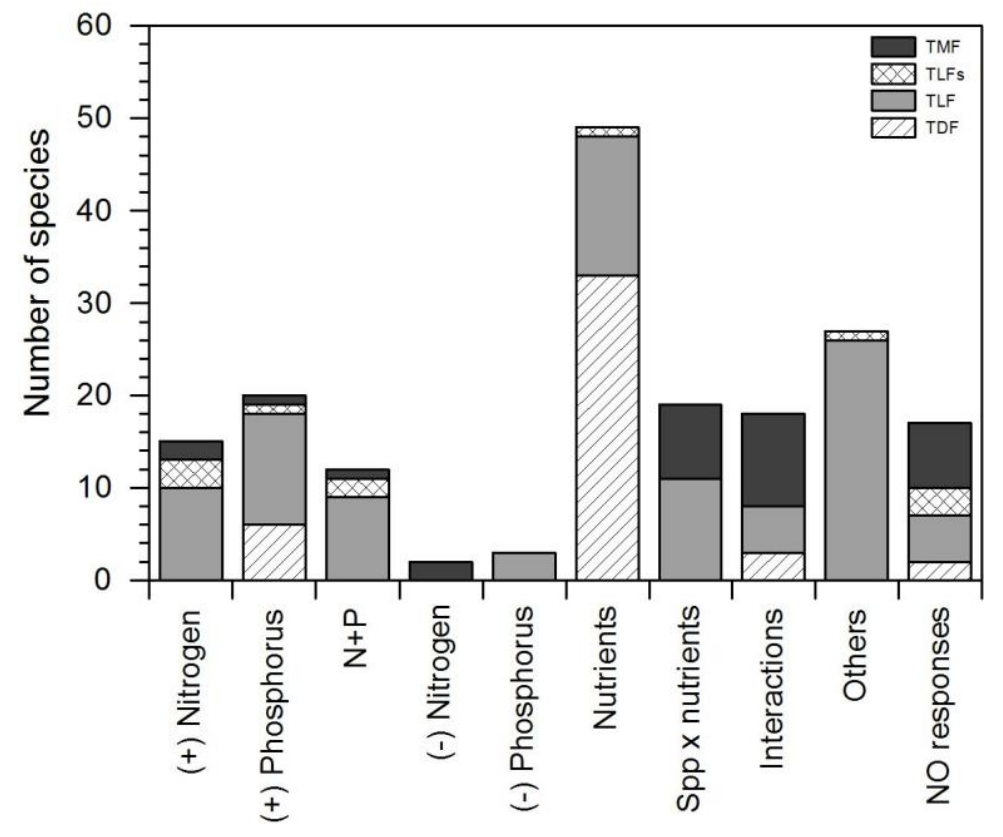

Figure 6.1 Summary of the type of responses found in seedling growth in 36 studies from 1987-2015. All studies analyze reponses of seedling to experimental fertilization. Responses do not show a specific pattern related with forest type. Abbreviations: (TMF), Tropical montane forest, (TLFs) Tropical secondary lowland forest, (TLF) Tropical lowland forest, (TDF) Tropical dry forest. 
Processes driven by nutrient availability might also be dependent on complementary traits interacting with soil nutrient cycles. For instance, in a P-rich environment, acceleration of litter decomposition enhances soil $\mathrm{N}$ mineralization, increasing community-level $\mathrm{N}$ uptake (Bracken et al., 2014). In Chapter 4, I reported that adding limiting nutrients to enhance growth additionally decreased the concentration of non-limiting nutrients relative to initial values (Chapter 4: Figure 4.3). The mechanism in this case might be attributed to the enhancement of $\mathrm{N}$ fixation by $\mathrm{P}$ addition.

In the forest understory (low percentage of canopy openness), light availability is thought to favour species with high plasticity and adaptability among shade-tolerant seedlings species. High temporal variation in light availability can increase the risk of negative carbon balance in seedlings due to the cost of maintaining new tissue (Paz, 2003). Thus, in the majority of shade-tolerant species, adaptability to variation in resource availability is very flexible whereas other life history strategies in species might need specific conditions to survive (i.e., pioneer species will be more adapted to high radiation, or compensatory adaptation mechanisms in specific niches).

In the results of Chapter 3, I found that light is not the main resource limiting growth in a montane forest species at $2000 \mathrm{~m}$ in southern Ecuador, or at least not to the extent expected for other tropical forests. Effects observed in both polled groups of common and rare species at $2000 \mathrm{~m}$ suggested overall community responses hide the effects occurring in individual species. Moreover, it was also clear that among common species there is not a similar strategy among them to adapt to variation in nutrient availability.

On the other hand, rare species did show similar coherent responses among them perhaps due to the the low intraspecific competition among individuals of the same rare species that probably enhance the effects of nutrient addition in every individual.

The fact that common species showed particular individual responses may result in one possible effective strategy to survive and grow as a result of the ability to tolerate changes in nutrient supply. The results observed in the seedling transplantation experiment with Pouteria torta (Chapter 5, Cárate-Tandalla et al., 2015) suggested no limitation for a specific main nutrient, although plants responded to $\mathrm{N}$ and $\mathrm{P}$ in terms of biomass allocation and SLA (Chapter 5: Figure 5.3a). 
Species richness (and therefore forest structure) in some natural forest communities has been found to vary over time, reflecting the capability of some species to recruit regularly and other species doing so only periodically (Norden et al., 2015). Therefore, evaluate changes in individual species will show changes in densities (i.e., due to mortality, recruitment and species richness) and might allow to contrasts real variation in species richness at the community level. Studying effects in abundant species helps to understand to what extent they are successful in establishing in the understory. In tropical forests, the majority of species reported in the studies reviewed (Table 6.1), responded in some degree to P availability but not as a general trait. In fact, several species, as Denslow et al. (1987) described, are also associated with phenotypic specialization.

To sum up, even though the evaluating specific effects of nutrient addition on seedlings in forests is not always possible due to excessive variation, it is clear that identifying differences in natural conditions is relevant to understanding how species will perform in long term.

\section{Seedlings Growth and Survival}

Growth expressed as relative growth rates (RGR: biomass, height, diameter, stem length, leaf number and P dependency; Table 6.1) were calculated in 29 of the 46 experiments reviewed. The majority of fertilization studies hypothesized positive effects by enhancing growth and strengthening seedlings, therefore guaranteeing better survival of seedlings in the understory.

Positive responses to nutrient addition were found in all tropical forests and were not differentiated by forest type (Figure 6.1). Responses were mostly associated to specific species requirements, although the majority of species studied (49 from 183 species) had preferential responses to the addition of nutrients in combination (e.g., NPK, Ca, Mg, micro nutrients: $\mathrm{B}, \mathrm{Zn}, \mathrm{Cu}, \mathrm{Mo}$ ) demonstrating that responsiveness of young forests is highly sensitive to nutrient addition. Furthermore, another vital factor influencing growth in many of these studies was light; 27 species showed high responsiveness to light availability (Figure 6.1) alone or in combination with nutrients. 
Fertilization using only main nutrients $(\mathrm{N}, \mathrm{P}$ or $\mathrm{N}+\mathrm{P})$ was more effective in a high number of species causing a higher percentage of seedlings growth rates among species (Figure 6.2). Limitation of growth by $\mathrm{P}$ was found in 18 species but was not related to the type of forest. Responses were observed in: tropical lowland forests distributed in Costa Rica (Alvarez-Clare et al., 2013), Singapore (Burslem et al., 1994) and Panama (Pasquini \& Santiago, 2012; Yawitt \& Wright, 2008), montane forest in Sri Lanka (Gunatilleke et al., 1997) and Ecuador (Chapter 3) and secondary dry forest in México (Huante et al., 1995b). Limitation of growth caused by $\mathrm{N}$ was observed in 16 species distributed in: tropical lowland forest in Borneo (Bungard et al., 2000) subtropical forest in China (Mo et al., 2008) and tropical dry forest in México (Salinas-Peba et al., 2013). Co-limitation by N+P was shown only in 8 species for tropical lowland forest in Costa Rica (Denslow et al., 1987), Malaysia (Nussbaum et al., 1995), Panama (Santiago et al., 2011) and Borneo (Turner et al., 1991) although co-limitation has been strongly suggested for all tropical forests (Wright et al., 2011; Fisher et al., 2013; Homeier et al., 2012) in the last years.

As expected, in most tropical forests, $\mathrm{P}$ was found to facilitate seedling survival (Alvarez-Clare et al., 2013; Burslem et al., 1994; Salinas-Peba et al., 2013) although, importantly, many studies included light (Denslow et al., 1990) and the interaction of both factors contributed greatly in some species (Ceccon et al., 2004). For instance, seedlings in young and old secondary dry forest (N-rich soils) in Yucatán, México performed better with the combination of $\mathrm{P}$, light and bulk driving positive survival in seedling community. 


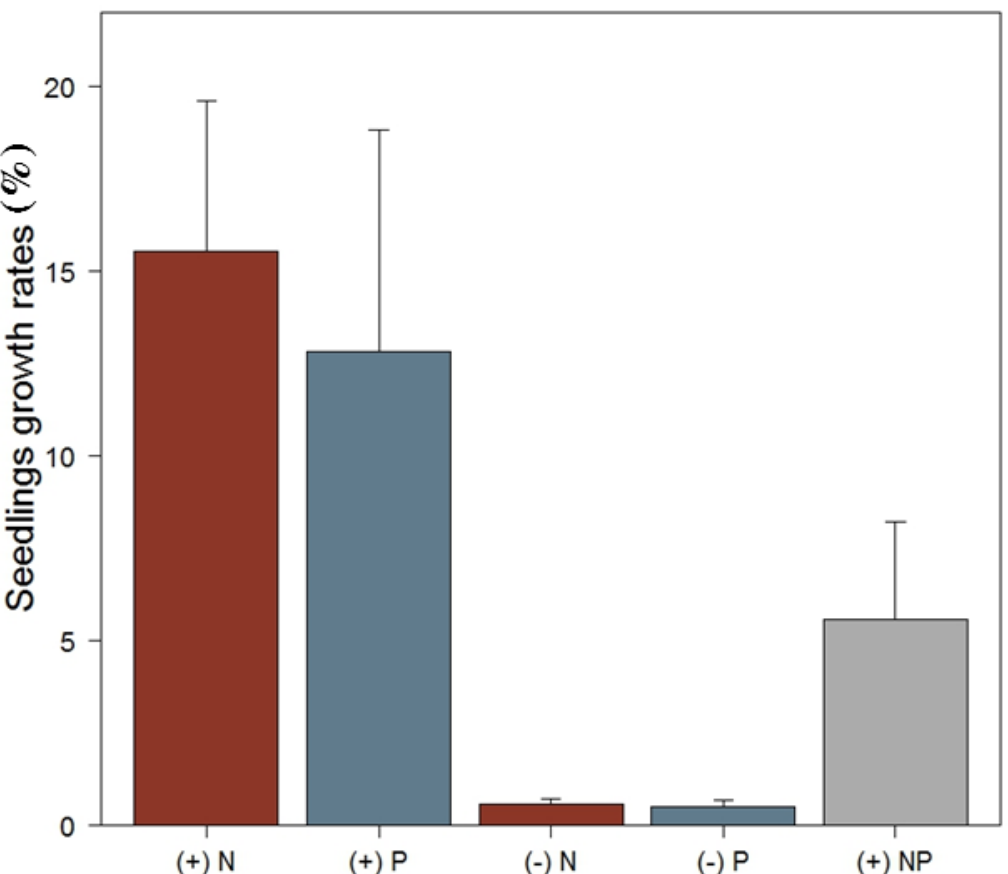

Figure 6.2 Comparisons of growth rates (y-axis) for 37 seedling species responding to N, P and NP experiments from 36 publications for tropical forests. Every column represents positive or negative responses reported.

Undoubtedly, a factor causing detrimental effects in seedling growth and survival is herbivory. Leaf area loss by herbivory alters growth trade-off mechanisms among coexisting species as a consequence of damage to photosynthetic structures (Eichhorn et al., 2010). Herbivory is expected to increase with the increment of $\mathrm{N}$ availability (Andersen et al., 2010), due to extra $\mathrm{N}$ making increase the palatability of leaves for predators.

Detrimental effects on growth caused by herbivory are also consequences of premature abscission of damage in leaves which affects leaf life span depending on the percentage of area damaged (Zverera et al., 2014). In some cases, even small amounts of damage affect leaves by reducing photosynthetic activity and interrupting circulation of water and nutrients through the xylem (Zangerl et al., 2002), which will retard growth. Selective pressure imposed by herbivores still depends upon the damage of individual seedlings (Eichhorn et al., 2006). Few studies investigating the role of nutrient addition in increment of herbivory (leaf area loss) suggested a dependency of this role with other complex variation agents (i.e., 
generalists vs. specialist consumption, plant pathogens, damage caused by fallen branches and damage by vertebrates). Responses found by Andersen et al. (2010) in BCI, Panama, demonstrated that $\mathrm{N}$ addition resulted in higher palatability in palm leaves, which were consumed up to $30 \%$ of the foliar area. This study also suggested herbivory can hide effects of real growth triggered by $\mathrm{N}$ acquisition. In a complementary study, Eichhorn et al. (2010) determined that species survival was negatively correlated with herbivory, although significant correlations to seedling growth were not clear.

Different responses were found for Pouteria torta (Chapter 5, Cárate-Tandalla et al., 2015) in a tropical montane forests suggesting that $P$ addition increased seedling herbivory in a common species. Also, Santiago et al. (2012) observed in five shade-tolerant species a particular responsiveness to the combination of $\mathrm{P}+\mathrm{K}$. Nevertheless, it is still unknown how $\mathrm{P}$ might activate palatability or improve quality of resources in leaves.

\section{Seedlings Biomass Allocation indicate Nutrient Limitations}

It is well known that seedling's biomass allocation increases aboveground while the investments for absorbing the nutrient available belowground decreases (Andersen et al., 2014; Poorter, 2000) which ocurre when nutrients (especially N) are available in soils. On the other hand, the increment in biomass belowground responds to the increment of absorption surface in roots looking for nutrients resources in poor soils (Poorter et al., 2011). Deficiencies in $\mathrm{N}$ availability on soils result in an accumulation of carbohydrates in leaves at the time that plants are driving higher levels of carbon allocated to roots. As a result nutrients availability affects primary photosynthesis, sugar metabolism and carbohydrate allocation between sources and sink tissues (Hermans, 2006). Root:shoot ratios are examined to compare changes in biomass allocation above and belowground, which are indicative of the type of resource limitation in plants. High values in root:shoot ratios are commonly observed in P-limited conditions due to the increase of starch concentration in leaves as a consequence of sugar export from the chloroplast to the cytosol (Ericsson, 1995).

Among all studies reported in this chapter, the majority showed an increase in root biomass in response to P addition (Burslem et al., 1994; Gunatilleke et al., 1997) caused by scarcity of $\mathrm{N}$ or another limiting resource in seedlings. 
Studies of seedling transplants found varied responses: in Mo et al (2008) the increment in $\mathrm{N}$ positively affected root biomass after one year of continued fertilization, suggesting that Schima superrba and Cryptocarya concinna are limiting by $\mathrm{P}$ in tropical forests of southern China. In Nussbaum et al., (1995), root biomass increments after NPK + dung suggested a limitation of other resources than nutrient availability. Responses were also found by Fetcher et al. (1996) in early successional species (light-demanding species), which responded to $\mathrm{N}+\mathrm{P}$ and $\mathrm{P}$ and showed species specific responses. Results of these studies suggested plants' phenotypical plasticity may also be involved in nutrient acquisition. For instance, in the pot experiments conducted by Wan Juliana et al. (2009) and Burslem et al. (1995) in rich-soil adapted species, $\mathrm{P}$ addition was observed to reduce root biomass, which might be attributed to plants also requiring $\mathrm{P}$ in aboveground tissues.

All the studies regarding biomass allocation show that in a competitive environment, each plant species has a unique set of responses to adapt to changing soil nutrients. This set of responses may include a variety od trade-off mechanisms (e.g., Burslem et al. 1994; Vincent et al., 2013; Palmiloto et al., 2004) to enhance nutrient uptake. The set of responses exhibited by each species indicates how well adapted they are to any particular habitat.

\section{Leaf traits change as a response of Nutrient addition}

Seedlings adapt to resource limitations by changing biomass allocation and morphology. In general, seedlings adapted to poor soils (i.e., low $\mathrm{N}$ availability) show lower SLA, RGR, lower foliar $\mathrm{N}$ content and lower maximum photosynthetic rate, but longer lifespan (Batzer et al., 2005). Seedlings adapted to rich soils (i.e., high N availability) show high relative growth rates, associated with higher SLA, RGR and higher foliar N (Andersen et al., 2014).

Nitrogen improves physiological leaf traits, enhancing seedlings performance through better leaf quality (Andersen et al., 2010). Light is also crucial to modify physiological mechanisms in leaves in some species (Press et al., 1996). Nutrient and light interactions were observed in four early successional species studied by Fetcher et al. (1996). In this case light played an important role in the increment of LA (leaf area) although seedlings were influenced by $\mathrm{N}$ addition to better establish even though $\mathrm{N}$ was not significant in changing 
photosynthesis. Contrasting results were shown by the shade-tolerant species Pouteria torta (Chapter 5, Cárate-Tandalla et al., 2015), which exhibited and increase in SLA after N addition but apparently there was no correlation between light and species performance.

In tropical montane forests, Thompson et al. (1992) studied different levels of light and $\mathrm{N}$, and found that positive responses in leaf morphology can also occur in the presence of only one resource in excess. For example, an increase of LAR (leaf area ratio) was observed in seedlings exposed to low light and higher level of $\mathrm{N}$ addition, but also SLW (specific leaf weight) was higher in seedlings exposed to strong light and low levels of $\mathrm{N}$ addition.

Interpretation of changes in morphological traits as SLA and LAR are challenging, since these attributes can be modified in response to different variations in resource availability (light and nutrients). For instance, Baraloto et al. (2006) found a negative response of SLA to $\mathrm{P}$ addition in nine tree species of the French Guiana while Wan Juliana et al., (2009), found positive increment of SLA in Lagestroemia floribunda as a response to P addition.

Interspecific seedling dynamics seems to be the result of ensemble factors driven by the variation of light availability and the location of seedlings in a heterogeneous understory. Many species responses similarly nutrients and/or light variations. However, it is clear that in all cases diversification of species is driven for a more complex chain of interactions, and species plasticity developed by phenotypical adaptation.

\section{Nutrient contents do not always anticipate responses of seedlings to fertilization}

Seedlings store $\mathrm{N}$ and $\mathrm{P}$ differently in tissues; $\mathrm{P}$ is manly retained internally as polyphosphates in vacuoles, whereas $\mathrm{N}$ must be converted into amino acids to be stored (Bracken et al., 2014). N:P ratios are interpreted by values estimated based on the proportion of nutrient retention in rich and poor soils. Ranges to describe limitation suggest values of 14 for N limitation and values over 16 for P limitation (Aerts \& Chapin, 200; Güseewell, 2004; Tessier \& Raynal, 2003).

$\mathrm{N}$ or P limitation is estimated by N:P ratios (Poorter \& Sack, 2012) for biomass fractions (stem, shoot and leaf). Nevertheless, the complexity in physiological plasticity to 
Chapter 6

nutrient availability results, in some cases, to over- or under-estimation of $\mathrm{N}: \mathrm{P}$ ratios as Ostertag (2010) and Townsend et al. (2007) stated. For instance, Ostertag (2010) suggested that $\mathrm{N}: \mathrm{P}$ ratios might be complicated to interpret because inorganic $\mathrm{P}$ stored in vacuoles is only $1 / 3$ of the total $\mathrm{P}$ although $2 / 3$ of this nutrient is moving through xylem and phloem. Additionally, in a comparison of nutrient uptake in seedling parts (new and mature leaves, shoot and roots), Schreeg et al. (2014) showed that real proportions of N against real P stocks are mainly associated with mature leaves. New leaves do not have real stocks due to the high metabolic nutrient-demanding activity.

In the publications reviewed, only the study conducted by Mo et al. (2008) showed a direct limitation for $\mathrm{N}$ among the tropical forests. Other comparisons (Chapter 4) showed N:P ratios indicating gradual limitation to $\mathrm{P}$ along common species in an elevation range. Species in Cajanuma (3000 m) presented the lowest limitation for P (Figure 4.4) although Cajanuma was considered to have P-rich soils. However, $\mathrm{N}$ and $\mathrm{P}$ contents in all species varied but Pouteria torta, which acquired $\mathrm{N}$ instead. Responses of Pouteria torta demonstrated an intermediate fertility level in Bombuscaro $(1000 \mathrm{~m})$ since any alteration in nutrient content occurred after fertilization (Andersen et al., 2014). Unexpected limitation for $\mathrm{P}$ when $\mathrm{P}$ is present in excess has been argued by Lawrence (2001) by postulating a "Luxury consumption" of nutrients as a mechanism of nutrient use. Luxury consumption indicates uptake of a nutrient over and above what is immediately required for growth (Sterne \& Elser, 2002) and might explain why seedlings responded to $\mathrm{P}$ rather than to $\mathrm{N}$ in some species.

In tropical seedlings, luxury consumption results in unbalanced growth, variable chemical composition and retention of nutrients in special storage compounds. Nevertheless, there is scarce knowledge about luxury consumption in seedlings so far, although Lawrence (2001) already suggested this mechanism as a possible trade-off in seedlings co-existence. However, this hypothesis still has to be studied further, since it does not consider that unexpected responses to nutrient limitation might also be related to other factors such as life history traits of individual species. 
Table 6.1 Summary of 36 references published about fertilization experiments in tree seedlings in tropical forests worldwide from 1987-2014. The main three approaches in every experiment has been indicated (exp). Main results of every reference have been compiled in four main sections affecting survival, growth and biomass allocation. The review included as well fertilization experiments cited in Lawrence (2003).

\begin{tabular}{|c|c|c|c|c|c|c|c|c|c|c|c|c|}
\hline $\mathbf{R}$ & species & site & Habit & $\exp$ & treat & abiotic & Time & Survival & Growth & Allocation & Leaves & Nutrients \\
\hline 1 & 4 & TLF $p$ & ST, LD & M & $\mathrm{P}, \mathrm{N}, \mathrm{NP}$ & & $31 \mathrm{~m}$ & $+: \mathrm{P}$ & >RGRd: P, NP & & & \\
\hline 2 & 8 & $\mathrm{TMF} p$ & palms & $\mathrm{T}$ & $\mathrm{N}$ & & $21 \mathrm{~m}$ & & n.s. & & $+\mathrm{H}: \mathrm{N}$ & $+1 \mathrm{~N}: \mathrm{N}$ \\
\hline 3 & 9 & TLF & $\mathrm{C}$ & $\mathrm{P}$ & $\mathrm{P}$ & $\begin{array}{l}\text { water, } \\
\text { soils }\end{array}$ & $12 \mathrm{~m}$ & & n.s. & $<\mathrm{RMR}$ & $\begin{array}{c}\text {-SLA: P+ } \\
\text {-NAR: *RGR }\end{array}$ & \\
\hline 4 & 4 & TLF $p$ & ST & $\mathrm{P}$ & $\mathrm{N}$ & light & $87 \mathrm{~d}$ & & >RGRw: N & $>\mathrm{TB}$ & & $+1 \mathrm{~N}: \mathrm{N}$ \\
\hline 4 & 4 & $\mathrm{TLF} p$ & ST & $\mathrm{P}$ & $\mathrm{N}$ & light & $63 \mathrm{~d}$ & & & & & \\
\hline 5 & 1 & TLF & shrub & $\mathrm{P}$ & $\begin{array}{l}\mathrm{N}, \mathrm{P}, \mathrm{K} \\
\mathrm{Mg}, \mathrm{Na}\end{array}$ & micro & $44 d$ & & $\begin{array}{l}\text { >RGRh: P } \\
\text { >RGRl: P }\end{array}$ & $\begin{array}{l}\text { >TB: } \mathrm{P} \\
\text { >RMR: } \mathrm{P}\end{array}$ & & \\
\hline 5 & 1 & TLF & shrub & $\mathrm{P}$ & $\begin{array}{c}\mathrm{P}, \mathrm{Na}, \mathrm{N}, \\
\mathrm{K}, \mathrm{Ca} \\
\mathrm{Mg}\end{array}$ & & $67,94 \mathrm{ds}$ & $-: \mathrm{P}$ & & $\begin{array}{c}\text { > TB: NP, PMg, PK } \\
\text { > RMR: NP, PMg, } \\
\text { P } \\
\text { >LMR: PMg, NP }\end{array}$ & & \\
\hline 5 & 1 & TLF & shrub & $\mathrm{P}$ & $\mathrm{N}, \mathrm{P}, \mathrm{K}$ & & $67,94 \mathrm{ds}$ & & & $\begin{array}{l}\text { >TB: ns } \\
\text { > RMR: NP }\end{array}$ & & \\
\hline 6 & 3 & TLF & ST & $\mathrm{P}$ & $\begin{array}{l}\mathrm{N}, \mathrm{P}, \mathrm{K} \\
\mathrm{Mg}, \mathrm{Ca}\end{array}$ & light & $18 \mathrm{~m}$ & n.s. & $>$ RGRw: all & $\begin{array}{l}\text { > RMR: } \mathrm{P}+\mathrm{N}+\mathrm{spp} \\
\text { >SMR: } \mathrm{P}+\mathrm{N}+\mathrm{spp} \\
\text { >LMR: } \mathrm{P}+\mathrm{N}+\mathrm{spp}\end{array}$ & $\begin{array}{l}+/- \text { SLA: } \\
\text { all+spp }\end{array}$ & $\begin{array}{l}+\mathrm{rN}: \mathrm{P} \\
+\mathrm{sN}: \mathrm{P} \\
+\mathrm{lN}: \mathrm{P}\end{array}$ \\
\hline 6 & 1 & TLF & ST & $\mathrm{P}$ & $\begin{array}{l}\mathrm{N}, \mathrm{P}, \mathrm{K} \\
\mathrm{Mg}, \mathrm{Ca}\end{array}$ & light & $18 \mathrm{~m}$ & & n.s. & < RMR: P & & $+\mathrm{rN}: \mathrm{P}$ \\
\hline 7 & 5 & TLF & ST, LD & $\mathrm{P}$ & $\mathrm{N}$ & light & $6 \mathrm{~m}$ & & & $\begin{array}{c}>\mathrm{TB},<\mathrm{RMR} \\
>\mathrm{LMR}\end{array}$ & +LAR: LD+spp & \\
\hline 8 & 6 & TDFsy & $\mathrm{C}$ & M & $\mathrm{N}, \mathrm{P}, \mathrm{NP}$ & & $24 \mathrm{~m}$ & & & & H: specific & $\begin{array}{l}\text { specific } \\
+1 P: N P\end{array}$ \\
\hline 8 & 6 & TDFso & $\mathrm{C}$ & M & $\mathrm{N}, \mathrm{P}, \mathrm{NP}$ & & $24 \mathrm{~m}$ & & & & $\mathrm{H}$ : specific & $\begin{array}{l}\text { Specific } \\
+ \text { lP: NP }\end{array}$ \\
\hline 9 & 2 & TDFsy & $\mathrm{C}$ & M & $\mathrm{N}, \mathrm{P}, \mathrm{NP}$ & light, bulk & $24 \mathrm{~m}$ & $+:$ NP*light & & & & \\
\hline 9 & 2 & TDFso & $\mathrm{C}$ & M & $\mathrm{N}, \mathrm{P}, \mathrm{NP}$ & light, bulk & $24 \mathrm{~m}$ & $+: \mathrm{N}^{*}$ light & & & & \\
\hline
\end{tabular}




\section{Chapter 6}

Table 6.1 (continued)

\begin{tabular}{|c|c|c|c|c|c|c|c|c|c|c|c|c|}
\hline $\mathbf{R}$ & species & site & habit & $\exp$ & treat & abiotic & Time & Survival & Growth & Allocation & Leaves & Nutrients \\
\hline 10 & com & TDFsy & $\mathrm{C}, \mathrm{R}$ & $\mathrm{M}$ & $\mathrm{N}, \mathrm{P}, \mathrm{NP}$ & light, bulk & $24 \mathrm{~m}$ & + : P*light*bulk & & & & \\
\hline 10 & com & TDFso & $\mathrm{C}, \mathrm{R}$ & M & $\mathrm{N}, \mathrm{P}, \mathrm{NP}$ & light, bulk & $24 \mathrm{~m}$ & $+:$ P*light*bulk & & & & \\
\hline 11 & 6 & TLF & shrubs & $\mathrm{P}$ & $\mathrm{N}, \mathrm{P}, \mathrm{NP}$ & micro & $16-29 w$ & & $\begin{array}{l}\text { > RGRw: N, P, } \\
\text { NP } \\
\text { >RGRh: N, P, } \\
\text { NP }\end{array}$ & & & \\
\hline 11 & 7 & TLF & shrubs & $\mathrm{P}$ & $\mathrm{N}, \mathrm{P}, \mathrm{NP}$ & micro & $8 w$ & & $\begin{array}{c}\text { <RGRs: P-, K } \\
\text { <RGRl: P- }\end{array}$ & & & +1P: P \\
\hline 12 & 7 & TMF & ST, LD & $\mathrm{T}$ & $\begin{array}{c}\text { N, } \mathrm{P}, \mathrm{Ca}, \\
\mathrm{Mg}\end{array}$ & $\begin{array}{c}\text { micro, } \\
\text { light }\end{array}$ & $6 \mathrm{~m}$ & +/- : light & $\begin{array}{l}\text { >RGRs: } \\
\text { spp+light }\end{array}$ & & & lnut: nut*light \\
\hline 12 & 3 & TMF & ST, LD & $\mathrm{P}$ & $\begin{array}{c}\text { N, P, Ca, } \\
\mathrm{Mg}\end{array}$ & $\begin{array}{c}\text { micro, } \\
\text { light }\end{array}$ & $6 \mathrm{~m}$ & +/- : light & $\begin{array}{l}\text { >RGRw: } \\
\text { spp+light }\end{array}$ & >LMR: light & & \\
\hline 13 & 5 & TLF & LSS & $\mathrm{T}$ & $\begin{array}{c}\mathrm{N}, \mathrm{P}, \mathrm{K} \\
\mathrm{Mg}\end{array}$ & & $24 \mathrm{~m}$ & & & & H: n.s. & \\
\hline 14 & 5 & TLF & ST & $\mathrm{T}$ & $\begin{array}{c}\mathrm{N}, \mathrm{P}, \mathrm{K} \\
\mathrm{Mg}\end{array}$ & light & $42 \mathrm{~m}$ & $-: \mathrm{H}$ & n.s. & & & \\
\hline 15 & 4 & TLF & ESS & $\mathrm{T}$ & $\mathrm{N}, \mathrm{P}, \mathrm{NP}$ & & $4-10 \mathrm{~m}$ & & $>$ RGRw: ns+NP & $\begin{array}{c}\text { >TB: N, NP+spp } \\
\text { >LMR: NP } \\
\text { > RMR: NP, P+spp }\end{array}$ & $\begin{array}{c}\text { +LA: } \mathrm{N+} \\
+ \text { SLA: light- }\end{array}$ & $\begin{array}{c}+1 \mathrm{P}: \mathrm{P}, \mathrm{NP} \\
+\mathrm{lN}: \mathrm{N}, \text { light }\end{array}$ \\
\hline 16 & 8 & TMF & $\mathrm{C}$ & $\mathrm{P}$ & $\mathrm{P}, \mathrm{Mg}$ & & $24 \mathrm{~m}$ & & $\begin{array}{l}\text { >RGRh: P } \\
\text { >RGRl: P }\end{array}$ & $\begin{array}{l}\text { > TB: } \mathrm{Mg}, \mathrm{P}- \\
\text { > RMR: } \\
\text { >SMR: } \mathrm{P} \\
\text { >LMR: } \mathrm{P}+\mathrm{spp}\end{array}$ & & \\
\hline 17 & com & $\mathrm{TDF}$ & $\mathrm{C}, \mathrm{R}$ & $\mathrm{P}$ & NPK & Soils & $60 \mathrm{~d}$ & & $>$ RGRw: all & $\begin{array}{l}\text { >TB: all } \\
\text { >RMR: poor soil } \\
\text { >SMR: N }\end{array}$ & $\begin{array}{c}\text { +LA: NPK half } \\
\text { spp } \\
\text { +SLA: n.s. }\end{array}$ & $+1 \mathrm{~N}:+$ all \\
\hline 18 & 9 & TDF & ESS & $\mathrm{P}$ & $\mathrm{P}$ & & $50 \mathrm{~d}$ & & >RGR-Pdep: P & $\begin{array}{l}\text { >TB: } \mathrm{P} \\
\text { >RMR: P- }\end{array}$ & LAR: n.s. & $\begin{array}{l}+\mathrm{PP}, \mathrm{lN}: \mathrm{P} \\
+\mathrm{PUE}:+\mathrm{P}\end{array}$ \\
\hline
\end{tabular}


Table 6.1. (continued)

\begin{tabular}{|c|c|c|c|c|c|c|c|c|c|c|c|c|}
\hline $\mathbf{R}$ & species & site & habit & $\exp$ & treat & abiotic & Time & Survival & Growth & Allocation & Leaves & Nutrients \\
\hline 19 & 4 & TLFs & ST & $\mathrm{P}$ & $\mathrm{N}, \mathrm{P}, \mathrm{NP}$ & water & $18 \mathrm{w}$ & n.s. & >RGRl: n.s. & $>\mathrm{TB}: \mathrm{NP}+\mathrm{spp}$ & & $\begin{array}{c}\text { Specific } \\
\text { luxury } \\
\text { consumption } \\
+\mathrm{sN}: \mathrm{NP} \\
+\mathrm{lN}: \mathrm{NP}\end{array}$ \\
\hline 20 & 2 & TLF & $\mathrm{C}$ & $\mathrm{T}$ & $\mathrm{N}$ & & $11 \mathrm{~m}$ & n.s. & $\begin{array}{l}\text { >RGRh:N } \\
\text { >RGRd: N }\end{array}$ & $\begin{array}{l}\text { >RMR: N } \\
\text { <SMR: N }\end{array}$ & & $\begin{array}{c}+\mathrm{N}: \mathrm{N} \\
-\mathrm{P}, \mathrm{K}: \mathrm{N} \\
>\mathrm{N}: \mathrm{P}: \mathrm{P}, \mathrm{K} \lim \\
>\mathrm{N} / \mathrm{K}: \mathrm{P}, \mathrm{Klim}\end{array}$ \\
\hline 21 & 4 & TLF & ESS & $\mathrm{T}$ & NPK & dug & $6 \mathrm{~m}$ & & $\begin{array}{l}\text { >RGRh: NPK } \\
\text { >RGRd: NPK }\end{array}$ & $\begin{array}{c}\text { >TB: NPK } \\
\text { >RMR: NPK*dug }\end{array}$ & & \\
\hline 22 & 6 & TLF & ST & $\mathrm{T}$ & $\mathrm{P}$ & light, soils & $20 \mathrm{~m}$ & $-: \mathrm{P}$ & > RGRd: light & $\begin{array}{l}\text { > TB: light+spp } \\
\text { >RMR, <LMR: P }\end{array}$ & & +lP: soil \\
\hline 23 & 1 & TLF & ST & $\mathrm{M}$ & $\mathrm{N}, \mathrm{P}, \mathrm{K}$ & light & $10 \mathrm{y}$ & & & & +SLA: NP & $\begin{array}{c}+\mathrm{lN}: \mathrm{N} \\
+\mathrm{lP}: \mathrm{P}, \mathrm{N}-, \mathrm{NK}-\end{array}$ \\
\hline 24 & 2 & TLF & ST, LD & $\mathrm{P}$ & $\mathrm{P}$ & & $87,126 \mathrm{~d}$ & & >RGRw: P & $>\mathrm{TB}: \mathrm{P}+\mathrm{spp}$ & & +rP,sP,lP: P \\
\hline 25 & 3 & TDF & $\mathrm{C}$ & $\mathrm{T}$ & $\mathrm{N}, \mathrm{P}, \mathrm{NP}$ & & $6 \mathrm{~m}$ & $+: \mathrm{N}, \mathrm{P}$ & $>$ RGRw: N & & & \\
\hline 26 & 5 & TLF & ST & M & $\mathrm{N}, \mathrm{P}, \mathrm{K}$ & micro & $8 \mathrm{y}$ & & $\begin{array}{c}\text { >RGRh: K, PK } \\
\text { >RGRl: n.s. }\end{array}$ & $>\mathrm{R} / \mathrm{S}: \mathrm{K}-$ & $\begin{array}{l}\text { +LAR: NP } \\
\text { +H: PK }\end{array}$ & $\begin{array}{c}+1 \mathrm{~N}: \mathrm{N}, \mathrm{P}, \mathrm{NP} \\
+\mathrm{rK}: \mathrm{K}\end{array}$ \\
\hline 27 & 5 & TLFso & ST & M & $\mathrm{N}, \mathrm{P}, \mathrm{K}$ & & $9 y$ & & & & & $\begin{array}{l}\text { >rN:P: N } \\
\text { >sN:P: N } \\
\text { <lN:P: N } \\
\text { < rN:P: Plim } \\
\text { <sN:P: Plim } \\
\text { >IN:P: Plim }\end{array}$ \\
\hline 28 & 4 & TMF & ST, LD & $\mathrm{P}$ & $\mathrm{N}$ & $\begin{array}{c}\text { light } \\
(\mathrm{s}, \mathrm{m}, \mathrm{w})\end{array}$ & $180 \mathrm{~d}$ & & & $\begin{array}{l}\text { >TB: N+*light } \\
\text { > RMR: N- }\end{array}$ & $\begin{array}{l}\text { +LAR: } \\
\text { N+wlight } \\
\text { +SLW: } \\
\text { slight+N- }\end{array}$ & $\begin{array}{l}+1 \mathrm{~N}: \mathrm{N}+\text { light } \\
\text { +fine-rN: } \mathrm{N}+\end{array}$ \\
\hline 29 & 2 & TLF & $\mathrm{ST}$ & $\mathrm{P}$ & NPK & light & $2 \mathrm{~m}$ & & $\begin{array}{c}\text { >RGRh: NPK } \\
\text { >RGRd: } \\
\text { NPK+spp }\end{array}$ & $\begin{array}{l}\text { >TB: NPK+spp } \\
\text { >LMR: spp }\end{array}$ & & \\
\hline 30 & 1 & TLF & C & $\mathrm{P}$ & NPK & & $6 \mathrm{~m}$ & & & TB: n.s. & & \\
\hline
\end{tabular}


Chapter 6

Table 6.1 (continued)

\begin{tabular}{|c|c|c|c|c|c|c|c|c|c|c|c|c|}
\hline $\mathbf{R}$ & species & site & habit & exp & treat & abiotic & Time & Survival & Growth & Allocation & Leaves & Nutrients \\
\hline 30 & 1 & TLF & $\mathrm{C}$ & $\mathrm{M}$ & $\mathrm{N}, \mathrm{P}$ & & $10 \mathrm{~m}$ & & $\begin{array}{l}\text { >RGRh: n.s. } \\
\text { >RGRd: n.s. }\end{array}$ & & & \\
\hline 30 & 1 & TLF & ST & M & NKP & & $10 \mathrm{~m}$ & & >RGRh: n.s. & & & \\
\hline 31 & 2 & TLFsd & ST & $\mathrm{T}$ & $\begin{array}{l}\text { N, P, K, } \\
\text { NPK }\end{array}$ & $\begin{array}{c}\text { litter } \\
(\mathrm{L}+, \mathrm{L}-)\end{array}$ & $6-13 \mathrm{~m}$ & n.s. & & & & $+1 \mathrm{P}:$ light $* \mathrm{~L}-$ \\
\hline 31 & 1 & TLFsd & LD & $\mathrm{P}$ & $\begin{array}{c}\text { N, P, K, } \\
\text { NPK }\end{array}$ & $\begin{array}{c}\text { litter } \\
(\mathrm{L}+, \mathrm{L}-)\end{array}$ & $167 \mathrm{~d}$ & & & $\begin{array}{l}\text { >TB: NPK } \\
\text { > RMR: NPK } \\
\text { > SMR: NPK } \\
\text { >LMR: NPK }\end{array}$ & $\begin{array}{l}\text { +SLA: L } \\
\text { +LA: NPK }\end{array}$ & \\
\hline 32 & 1 & TLF & ST & $\mathrm{P}$ & $\begin{array}{c}\text { N, P, Ca, } \\
\text { Mg }\end{array}$ & & $54 \mathrm{~d}$ & & >RGRl: P & $\begin{array}{l}\text { <RMR: P } \\
\text { <SMR: P } \\
\text { >LMR: P }\end{array}$ & $\begin{array}{l}\text { +LA: P } \\
\text { +SLA: P }\end{array}$ & \\
\hline 33 & 3 & TLF & ST & M & $\begin{array}{c}\mathrm{N}, \mathrm{P}, \mathrm{K}, \\
\mathrm{Ca}, \mathrm{Mg}, \\
\mathrm{B}, \\
\mathrm{Zn}, \mathrm{Cu}, \\
\mathrm{Mo}\end{array}$ & $\begin{array}{l}\text { water, } \\
\text { light, } \\
\text { icro }\end{array}$ & $5 \mathrm{y}$ & & $\begin{array}{c}\text { >RGRh: all } \\
\text { >RGRl: specific }\end{array}$ & & & \\
\hline 34 & com & TMF & ST & M & $\mathrm{N}, \mathrm{P}, \mathrm{NP}$ & & $5 \mathrm{y}$ & $-: N$ & $\begin{array}{l}\text { >RGRh: } n . s . \\
\text { > RGRl: } P \text { in } \\
2013\end{array}$ & & & \\
\hline 35 & 6 & TMF & ST & M & $\mathrm{N}, \mathrm{P}, \mathrm{NP}$ & & $5 \mathrm{y}$ & & & $\begin{array}{l}\text { >SMR: all+spp } \\
\text { >LMR: all+spp } \\
\text { R/S: specific }\end{array}$ & $\begin{array}{c}\text { +/- SLA: N, } \\
\text { P+spp } \\
\text { +LAR: N, NP }\end{array}$ & $\begin{array}{c}\text { specific } \\
+ \text { +lN: N, NP } \\
+ \text { lP: P,NP } \\
\text { >IN:P: Plim }\end{array}$ \\
\hline 36 & 1 & $\mathrm{TMF}$ & ST & $\mathrm{T}$ & $\mathrm{N}, \mathrm{P}, \mathrm{NP}$ & & $5 \mathrm{y}$ & $-: N$ & >RGRd: all & $\begin{array}{c}\text { >RMR: P } \\
\text { <SMR: P } \\
\text { <LMR: N } \\
\text { >R/S: P } \\
\text { >R/TB: } \mathrm{P} \\
\text { >R/L: } \mathrm{P} \\
\text { > sl-ratio, sw- } \\
\text { ratio: } \mathrm{N}\end{array}$ & $\begin{array}{l}\text { +H: P, NP } \\
\text { +SLA: N } \\
\text { +SLA: n.s. }\end{array}$ & $>\mathrm{C} / \mathrm{N}: \mathrm{N}-$ \\
\hline
\end{tabular}

$(R N)$ reference number. 1. Alvarez-Clare et al. 2013, 2. Andersen et al. 2010, 3. Baraloto et al. 2006, 4. Bungard et al. 2000, 5. Burslem et al. 1994, 6. Burslem et al. 1995, 7. Cai, et al. 2008, 8. Campo and Dirzo 2003, 9. Ceccon et al. 2003, 10. Ceccon et al. 2004, 11. Denslow et al. 1987, 12. Denslow et al. 1990, 13. Eichhorn et al. 2006, 14. Eichhorn et al. 2010, 15. Fetcher et al. 1996, 16. Gunatilleke et al. 1997, 17. Huante et al. 1995a, 18. Huante et al. 1995b, 19. Lawrence 2001, 20. Mo, Li \& Gundersen, 2008, 21. Nussbaum et al. 1995, 22. Palmiotto et al. 2004, 23. Raaimakers and Lambers 1996, 24. Pasquini and Santiago 2012, 25. Salinas-Peba et al 2013, 26. Santiago et al. 2011, 27. Schreeg et al.2014, 28. Thompson et al. 1992, 29. Turner, et al. 1991, 30. Turner et al. 1993, 31. Vincent et al. 2013, 32. Wan Juliana et

al. 2009, 33. Yawitt and Wright 2008, 34. this thesis, Chapter 3, 35. this thesis, Chapter 4, 36. Cárate-Tandalla et al., 2015. 


\section{Table abbreviations ordered by column:}

\begin{tabular}{|c|c|c|c|}
\hline$($ site $)=$ & forests type & \multicolumn{2}{|c|}{$\begin{array}{l}\text { TLF: tropical lowland forest, } \\
\text { TLFp: primary tropical lowland forest, } \\
\text { TLFs: secondary tropical lowland forest, } \\
\text { TLFsd: semi deciduous tropical lowland forest, } \\
\text { TMF: tropical montane forest, } \\
\text { TDFsy: secondary young tropical dry forest, } \\
\text { TDFso: secondary old tropical dry forest. }\end{array}$} \\
\hline$($ habit $)=$ & species type & \multicolumn{2}{|c|}{$\begin{array}{l}\text { ST: shade tolerance, } \\
\text { LD: light demanding, } \\
\text { C: common species, } \\
\text { R: rare species, } \\
\text { LSS: late successional species, } \\
\text { ESS: early successional species. }\end{array}$} \\
\hline$(\exp )=$ & experiment type & \multicolumn{2}{|l|}{$\begin{array}{l}\text { M: in situ, monitoring; } \\
\text { T: in situ, transplantation; } \\
\text { P: pot experiment. }\end{array}$} \\
\hline$($ abiotic $)=$ & other abiotic factors & \multicolumn{2}{|c|}{$\begin{array}{l}\text { micro: micronutrients, } \\
\text { light levels (s: strong, m: medium, w: weak) } \\
\text { litter levels= L+: with litter, } \\
\text { L-: without litter. }\end{array}$} \\
\hline$($ Growth $)=$ & relative growth rates & $\begin{array}{l}\text { RGRd: Diameter, } \\
\text { RGRw: Biomass, } \\
\text { RGRh: Height, }\end{array}$ & $\begin{array}{l}\text { RGRs: Stem length, } \\
\text { RGRI: Leaf number, } \\
\text { RGR_Pdep: P dependency }\end{array}$ \\
\hline$($ Allocation $)=$ & biomass allocation and ratios & $\begin{array}{l}\text { TB: Total biomass, } \\
\text { RMR: root mass, } \\
\text { SMR: shoot mass, } \\
\text { LMR: leaf mass ratio, } \\
\text { Sw-ratio: stem width ratio }\end{array}$ & $\begin{array}{l}\text { R/S: root-shoot, } \\
\text { R/TB: root-total biomass, } \\
\text { R/L: root-leaf, } \\
\text { sl-ratio: stem length ratio, }\end{array}$ \\
\hline$($ Leaves $)=$ & leaves attributes and herbivory & $\begin{array}{l}\text { H: herbivory, } \\
\text { SLA: specific leaf area, } \\
\text { NAR: net assimilation rate, } \\
\text { LAR: leaf area ratio, } \\
\text { SLW: specific leaf weight, } \\
\text { LA: total leaf area }\end{array}$ & \\
\hline$($ Nutrients $)=$ & nutrient concentrations and ratios & $\begin{array}{l}\text { rN: root Nitrogen, } \\
\text { sN: shoot Nitrogen, } \\
\text { IP: foliar Phosphorus, } \\
\text { IN: foliar Nitrogen, } \\
\text { Inut: foliar nutrients, } \\
\text { PUE: P use efficiency, }\end{array}$ & $\begin{array}{l}\text { rK: root Potassium } \\
\text { rN:P: root N-P ratio, } \\
\mathbf{s N : P : ~ s h o o t ~ N - P ~ r a t i o , ~} \\
\text { IN:P: foliar N-P ratio; } \\
\text { finer-rN: fine root N } \\
\text { C/N: Carbon-N ratio }\end{array}$ \\
\hline
\end{tabular}

In all effects: $(+)$ indicates particular factors combination producing the effect,

$(*)$ indicates interactions in different levels,

$(+)$ positive effects, $(-)$ negative effects,

$(>)$ increment, $(<)$ decrease,

$(\mathbf{N}+)$ indicates high levels of $\mathrm{N}$ fertilization,

(P-, K-) indicates low levels of $\mathrm{P}, \mathrm{K}$ fertilizations. 


\subsection{General conclusions}

\subsubsection{Final conclusions}

Seedlings community dynamics responded to nutrient addition moderately since mechanisms regulating growth and survival are diverse, and affected by multiple biotic and abiotic factors. Studying community responses to nutrient addition suggested that exclusive limitation by a single nutrient does not occur in this community, and possibly montane forests in general (Figure 3.1, 3.2). Instead, the seedling community responded to multiple limiting nutrients or co-limitation between $\mathrm{N}$ and $\mathrm{P}$ as other studies have suggested for tropical forests (Wright et al., 2011; Alvarez-Clare et al. 2013). Additionally, responses at the community level might hide specific effects since every species performs according to particular adaptive mechanisms in order to survive and the net effect of these at the community level may not be obvious. Species trade-off mechanisms might explain plasticity in resource acquisition, strong dependency of nutrients or light, and/or life history in functional groups (common versus rare species) and individual species.

Decreasing seedling density and recruitment rates in response to nutrient addition in all groups at San Francisco, suggested that other soil characteristics drive seedling establishment (Figure 3.2). The fact that herbivory was higher in the $\mathrm{N}$ addition treatment is comparable with other tropical forests, suggesting that herbivory may mask real growth responses to nutrient addition (Andersen et al., 2010) by the destabilization of physiological seedling strength (e.g., carbon loss by foliar damage) (Zangerl et al., 2002; Kitajima, 1996; Poorter, 2005).

Changes in seedling assemblages were not evident from 2011-2013 in this community. Seedling species richness suffered a significant decrease only in 2013 in all experimental plots (Figure 3.3). However, these observations are not enough to assume that nutrient deposition will generally decrease species richness over the short term. Seedling populations in tropical forests (and many other ecosystems) fluctuate much more than adult populations (Norden et al., 2015) due to variability in phenology, inter-annual variation in flower and fruit production, as well as variation in the resources that enable reproduction. Thus, it will require a far longer period of monitoring under continuous fertilization to determine the effect of nutrient addition on reproduction, recruitment and seedling dynamics. 
Seedlings were more responsive to moderate fertilization than matures trees due to the high requirements of major nutrient in young life stages. At the seedling stage, growth is important (Kitajima \& Myers, 2008), as is minimizing carbon loss (Poorter, 2005), so seedlings will benefit from $\mathrm{N}$ and/or $\mathrm{P}$ addition and put on height or leaves to better survive in a highly competitive environment. We observed in all six common species over the elevational range, significant accumulation of $\mathrm{N}$ and $\mathrm{P}$ after fertilization, pointing to a high consumption of the additional nutrient stock from the soil (Figures 4.3).

All the species analyzed over the elevational range seemed to be limited by $\mathrm{P}$ (Figure 4.4). However, limitation by $\mathrm{P}$ tended to decrease with elevation: in Bombuscaro and San Francisco values of N:P ratios were $>25$ and in Cajanuma N:P ratios were $>20$. However, the morphological responses of leaves varied among species. Grafferieda harlingii increased SLA and LAR in response to $\mathrm{N}$ addition suggesting $\mathrm{N}$ acquisition and use, but Pouteria torta and Graffenrieda emarginata showed no change, suggesting a neutral balance in acquisition and nutrient use (Figure 4.3; Table 4.2). In general, shade-tolerant species allocate more biomass to belowground reserves than aboveground, in order to protect in some way from herbivory. Differential biomass allocation in seedlings of all species confirmed my expectations regarding the specific responsiveness to fertilization over the elevation gradient (Figure 4.6, Table 4.2).

Additionally, I found no significant correlation between growth and light availability at the community-level, or in Pouteria torta. Nevertheless, it is known that shade-tolerant species have strong trade-off mechanisms to survive in low light in order to maintain carbon balance, which may drive diversification of strategies for nutrient use (Garwood, 1996; Turner, 2001).

In my study, such a diversification of strategies was observed in the various morphological responses of seedlings at all three sites (Figure 4.1, 4.6). The fact that species did not show expected responses to additional nutrients suggests that other variables that were not recorded may have responded instead, including photosynthetic capacity, development of defense structures, or even nutrient storage to enable opportunistic growth activated by the higher light of canopy openings, or sun flecks. These seedlings often depend on short term irradiation in understory, since shade-tolerant seedlings acclimatize much faster to increases of light and carbon fixation (Poorter, 2005) 
Maintenance of a positive carbon balance is a prerequisite for long-term survival and growth (Kitajima, 2007). This balance does not necessarily mean the maximization of the rate of carbon gain and growth (in terms of maximum total photosynthesis and minimal total respiration). In the comparison of six species $\mathrm{C} / \mathrm{N}$ ratios (Figures $4.3 \mathrm{~d}$ and $\mathrm{S} 4.2$ ), $\mathrm{N}$ content was neutral in the species less responsive to nutrient addition (i.e., C. racemosa, P. torta and $P$. angustifolia).This might be the result of species plasticity in nutrient update since no strong morphological changes were observed other than storage of $\mathrm{N}$ and $\mathrm{P}$ in leaves. However, further research is required in order to determine whether species are maximizing photosynthesis.

Uniqueness in responses were observed in the common species Pouteria torta but not completely understood. However, I conclude that this species is well adapted to the poor soils of Bombuscaro. Diameter growth increased 30-50\% compared with control seedlings after N and $\mathrm{P}$ addition (Figure 5.2). Additionally, seedlings showed an increase of $40 \%$ in SLA (Figure 5.3a), which must be closely related with higher foliar nutrient accumulation of $\mathrm{N}$ and $\mathrm{P}$. Further, $\mathrm{N}$ and $\mathrm{P}$ are involved in building photosynthetic proteins as Rubisco, produce ATP, NADPH and made cellular membranes permeable (Marschner, 1995; Walker et al., 2014). Conversely, as neither $\mathrm{N}$ nor $\mathrm{P}$ changed in foliar concentrations (Table 5.2; Figure $5.3 \mathrm{c}$ ), I cannot compare photosynthetic rates in response to $\mathrm{N}$ or $\mathrm{P}$ addition although productivity was shown to increase in other studies (e.g., for Alseis blackniana: Pasquini \& Santiago, 2012).

Finally, my study demonstrated that individual species are more responsive to nutrient availability than the community of species. Responses showed specific mechanisms driving co-existence of common species since expected hypotheses were not achieved for all species. Nutrients improved growth (Pouteria torta) and mediated herbivory (Graffenrieda emarginata, Palicourea angustifolia) indicating that young plants more easily assimilate nutrients to survive. Responses to nutrient addition of tropical montane forests in Ecuador are gradual and slow, and involve many mechanisms that are only reproducible in natural conditions, but not yet completely understood. 


\subsubsection{Implications}

Nutrient deposition as an effect of climate change is affecting forests in the south of Ecuador. Minimum nutrient deposition is estimated at $5 \mathrm{~kg} \mathrm{ha}^{-1}$ for $\mathrm{N}, 0.49 \mathrm{~kg} \mathrm{ha}^{-1}$ for P (Homeier et. al., 2013) due to wind bringing particles from eastern Amazon where many forests are burned and cleared (Fabian et al., 2005; Wilcke et al., 2013). Therefore, the moderate nutrient fertilization conducted by the Ecuadorian NUMEX project is a realistic scenario of nutrient deposition in the region, and the responses of seedlings that we observed can be consideredrealistic future changes.

In terms of biodiversity conservation, the moderate responses of the community could allow species to adapt to new conditions without drastically modifying seedling assemblages in the short term.

On the other hand, common species in the three study sites responded with varying morphological differences although there appeared to be no significant effect on survival. We observed higher mortality in Pouteria torta as a result of $\mathrm{N}$ addition (Chapter 3). Relevant information from these results highlights the gradual change of seedling responses to achieve carbon balance before death. Nonetheless, complementary studies will demonstrate other sources of variance in the responses of seedling species and forest dynamics in general.

Montane forests in the south of Ecuador are described as biodiversity hotspots (Homeier \& Werner, 2008; Gradstein et al., 2008; Bendix et al., 2013) but at the same time the region is one of the most fragmented zones in the country due to new settlements, changing land use and the mining industry. Consequently, knowledge about primary forests should be prioritized for future actions.

I found that the montane forest seedlings responded slowly to nutrient deposition in southern Ecuador. Other results from the same experiment (NUMEX) found changes in mycorrhizal ecology (Camenzind et al., 2014; Krashevska et al., 2014), altered soil N cycles (Baldos et al., 2015; Müller K., 2014) and fertilization effects in canopy soils (Matson et al., 2015). My study contributes to new knowledge about regeneration mechanisms of common species and the community of species, and is ecological evidence to elucidate how these might be modified by altered nutrient concentrations in montane forests. 


\subsection{Future work}

Regeneration of tree species includes a chain of interactions and variations, which are potential extensions of this study. It is important to continue monitoring tagged seedlings in the NUMEX experimental plots in Bombuscaro, San Francisco and Cajanuma in order to identify new sources of variation for seedling survival (e.g. potential density-dependence mortality in productive years, addition effects of drought in dry years). Long term monitoring of fertilization studies are scarce for seedling dynamics in the tropics (Raaimakers \& Lambers, 1996; Santiago et al., 2011; Schreeg et al., 2014; Yawitt \& Wright, 2008), and few include spatiotemporal variation of seedling coexistence. For instance, belowground competition must be considered to estimate mature tree responsiveness to additional nutrient availability and how the number of seedlings might change in the presence of a higher number of paternal trees. Inter-annual changes in productivity of mature trees (flowering and fruiting) would also be a source of variation directly related to seedling densities in natural conditions and affected by nutrient limitation in the forests.

During the fieldwork in San Francisco in 2013, there was a huge sudden increment of seedling recruitment of some species (e.g. Clusia sp., Prunus sp. nov., Myrcia sp. nov., see Table S3.1) due to a massive flowering event starting in 2011-2012. It is evident that annual differentiation between species will also contribute to the densities of species. For that reason, more censuses will allow us to determine whether the effects of fertilization are also contributing to the natural spatiotemporal differentiation of species survival.

Reciprocal transplantation experiments in this study had been designed with the aim of describing unique species strategies. In a parallel experiment to seedling transplantation experiment conducted in Bombuscaro (STE1) and following the design of Santiago (2012), I aimed to compare a light availability gradient and nutrients availability in three species commonly distributed in San Francisco. By planting all species in two locations (lower slope vs. upper slope), I hypothesized different adaptability capacity of ravine species to bridge and vice versa in relation to light availability, microhabitat and nutrients. So far, this experiment is not concluded and it was not included in this dissertation. However, the conclusion from this approach will provide further insight into common species preferences of vital aboveand below-ground resources such as light, microhabitats and soil conditions (e.g. ravine and ridge). 
As a replicate of STE in Bombuscaro, we installed in San Francisco an additional STE in December 2013 using one of the most common species in this study site: Prunus sp. nov. This experiment is also not included in this dissertation due to the time required to assess growth in this species, since Prunus sp.nov. grew slow and it will require more time to observe changes induced by additional nutrient availability.

Finally, application of physiological experiments (e.g. pot experiments) in some key species in montane forests would also help to comprehend some poorly-understood mechanisms since photosynthetic responses (as Huante et al., 1995b conducted) were not measured. Thus, complementary information would probably facilitate the identification of specific strategies for seedling performance. 


\section{REFERENCES}

Aber, J., McDowell, W., Nadelhoffer, K., Magill, A., Berntson, G., Kamakea, M., et al., \& Fernandez, I. (1998). Nitrogen saturation in temperate forest ecosystems. BioScience, 921-934.

Aerts, R. and Chapin, F.S. (2000). The mineral nutrition of wild plants revisited: a reevaluation of processes and patterns. Advances in Ecological Research 30:1-67.

Alvarez-Clare, S., \& Kitajima, K. (2007). Physical defense traits enhance seedling survival of geotropically tree species. Functional Ecology, 21(6), 1044-1054.

Alvare-Clare, S., \& Kitajima, K. (2009). Susceptibility of tree seedlings to biotic and abiotic hazards in the understory of a moist tropical forest in Panama. Biotropica, 41(1), 47-56.

Alvarez-Clare, S., Mack, M. C., \& Brooks, M. (2013). A direct test of nitrogen and phosphorus limitation to net primary productivity in a lowland tropical wet forest. Ecology, 94(7), 1540-1551.

Andersen, K. M., Corre, M.D., Turner, B.L. \& Dalling, J.W. (2010). Plant-soil associations in a lower tropical forest: physiological acclimation and herbivore-mediated responses to nitrogen addition. Functional Ecology 24(6): 1171-1180.

Andersen, K. M., Turner, B. L., \& Dalling, J. W. (2014). Seedling performance trade-offs influencing habitat filtering along a soil nutrient gradient in a tropical forest. Ecology, 95(12), 3399-3413.

Ashton, M. S., Singhakumara, B.M.P. \& Gamage, H.K.(2006). Interaction between light and drought affect performance of Asian tropical tree species that have differing topographic affinities. Forest Ecology and Management 221: 42-51.

Bachelot, B \& Kobe, R.K. (2013). Rare species advantage? Richness of damage types due to natural enemies increases with species abundance in a wet tropical forest. Journal of Ecology. doi:10.1111/1365-2745.12094.

Bai, X., Queenborough, S.A., Wang, X., Zhang, J., Li, B., Yuan, Z., Xing, D., Lin, F., Ye, J. \& Hao, Z. (2012). Effects of local biotic neighbors and habitat heterogeneity on tree and shrub seedling survival in an old-growth temperate forest. Oecologia. doi: 10.1007/s00442-012-2348-2. 
Baldos, A., Corre, M. D. \& Veldkamp, E. (2015). Responses of N cycling to nutrient inputs in forest soils across a 1000-3000 m elevation gradient in the Ecuadorian Andes. Ecology 96(3): 749-761.

Baltzer, J. L., Thomas, S. C., Nilus, R., \& Burslem, D. F. R. (2005). Edaphic specialization in tropical trees: physiological correlates and responses to reciprocal transplantation. Ecology, 86(11), 3063-3077.

Baker, T. R., Swaine, M. D. \& Burslem, D.F.R.P. (2003). Variation in the tropical forest growth rates: combined effects of functional group composition and resource availability. Perspectives in Plant Ecology Evolution and Systematics. Vol. 6. Issues1-2: 21-36.

Baraloto, C. \& Goldberg, D. E. (2004). Microhabitat associations and seedling bank dynamics in a neotropical forest. Oecologia 141: 701-712.

Baraloto, C., Goldberg, D. E. \& Bonal, D. (2005). Performance trade-offs among tropical tree seedlings in contrasting microhabitats. Ecology 86 (9), pp. 2461-2472.

Baraloto, C., Bonal, D., \& Goldberg, D. E. (2006). Differential seedling growth response to soil resource availability among nine neotropical tree species. Journal of Tropical Ecology, 22(05), 487-497.

Barberis, I. M., \& Tanner, E. V. (2005). Gaps and root trenching increase tree seedling growth in Panamanian semi-evergreen forest. Ecology, 86(3), 667-674.

Barton, K. E., \& Hanley, M. E. (2013). Seedling-herbivore interactions: insights into plant defence and regeneration patterns. Annals of botany, 112(4), 643-650.

Bates, D., Maechler, M., Bolker, B. \& Walker, S. (2014). _lme4: Linear mixed-effects models using Eigen and S4_. R package version 1.1-7, <URL: http://CRAN.Rproject.org/package $=\operatorname{lme} 4>$.

Beckage, B., \& Clark, J. S. (2003). Seedling survival and growth of three forest tree species: the role of spatial heterogeneity. Ecology, 84(7), 1849-1861.

Bellard, C., Bertelsmeier, C., Leadley, P., Thuiller, W., \& Courchamp, F. (2012). Impacts of climate change on the future of biodiversity. Ecology letters, 15(4), 365-377.

Bellingham, P. J., \& Richardson, S. J. (2006). Tree seedling growth and survival over 6 years across different microsites in a temperate rain forest. Canadian Journal of Forest Research, 36(4), 910-918. 
Bendix, J., Homeier, J., Ortiz, E.C., Emck, P., Breckle, S.-W., Richter, M. \& Beck, E. (2006). Seasonality of weather and tree phenology in a tropical evergreen mountain rain forest. Int. J. Biometeorol. 50: 370-384.

Bendix, J., Beck, E., Bräuning, A., Makeschin, F., Mosandl, R., Scheu, S., \& Wilcke, W. (eds). (2013). Ecosystem services, biodiversity and environmental change in a tropical mountain ecosystem of South Ecuador. Ecological Studies Vol. 221, Springer Verlag, Berlin, Heidelberg, New York.

Boege, K., \& Marquis, R. J. (2005). Facing herbivory as you grow up: the ontogeny of resistance in plants. Trends in Ecology \& Evolution, 20(8), 441-448.

Born, J., Pluess, A.R., Burslem, D.F.R.P., Nilus, R., Maycock, C.R. \& Ghazoul, J. (2014). Differing life history characteristics support coexistence of tree soil generalist and specialist species in tropical rain forests. Biotropica 46(1): 58-68.

Born., J., Bagchi, R., Buslem, D., Nilus, R., Tellenbach, C., Pluess, A.R., \& Ghazoul, J. (2015). Differential responses of Dipterocarp seedlings to soil moisture and microtopography. Biotropica 47(1): 49-58.

Boy, J., Valarezo, C. \& Wilcke, W. (2008). Water flow paths in soil control element exports in an Andean tropical montane forest. European Journal of Soil Science. 59, 12091227.

Bracken, M.E., Hillebrand, H., Borer, E.T., Seabloom, E.W., Cebrian, J., Cleland, E.E., Elser, J.J., Gruner, D.S., Harpole, W.S., Ngai, J.T. \& Smith, J.E. (2014). Signatures of nutrient limitation and co-limitation: responded of autotroph internal nutrient concentration to nitrogen and phosphorus additions. Oikos. doi:10.1111/oik.01215.

Brehm, G., Homeier, J., Fiedler, K., Kottke, I., Illig, J., Nöske, N.M., Werner, F.A. \& Breckle, S.W. (2008). Mountain rain forests in Southern Ecuador - limited knowledge and diverging patterns. In: Beck E, Bendix J, Kottke I, Makeschin F \& Mosandl R (eds.) Gradients in a Tropical Mountain Ecosystem of Ecuador. Ecological Studies Vol. 198, Springer Verlag, Berlin, pp 15-23.

Brenes-Arguedas, T., Roddy, A. B., Coley, P. D., \& Kursar, T. A. (2011). Do differences in understory light contribute to species distributions along a tropical rainfall gradient?. Oecologia, 166(2), 443-456. 
Bungard, R. A., Scholes, J. D., \& Press, M. C. (2000). The influence of nitrogen on rain forest dipterocarp seedlings exposed to a large increase in irradiance. Plant, Cell \& Environment, 23(11), 1183-1194.

Burslem, D. F. R. P., Turner, I. M., \& Grubb, P. J. (1994). Mineral nutrient status of coastal hill dipterocarp forest and adinandra belukar in Singapore: bioassays of nutrient limitation. Journal of Tropical Ecology, 10(04), 579-599.

Burslem, D. F. R. P., Grubb, P. J., \& Turner, I. M. (1995). Responses to nutrient addition among shade-tolerant tree seedlings of lowland tropical rain forest in Singapore. Journal of Ecology, 113-122.

Cai, Z. Q., Poorter, L., Han, Q., \& Bongers, F. J. J. M. (2008). Effects of light and nutrients on seedlings of tropical Bauhinia lianas and trees. Tree physiology, 28(8), 1277-1285.

Camenzind, T. \& Rilling, M.C. (2013) Extraradical arbuscular mycorrhizal fungal hyphae in an organic tropical montane forest soil. Soil Biology \& Biochemistry 64:96-102. doi: 10.1016/j.soilbio.2013.04.011

Camenzind, T., Hempel, S., Homeier, J., Horn, S., Velescu, A., Wilcke, W. \& Rilling, M. (2014). Nitrogen and phosphorus addition impact arbuscular mycorrhizal abundance and molecular diversity in a tropical montane forest. Global Change Biology 20: 3646-3659.

Camenzind, T., Papathanasiou, H.J., Förster, A., Dietrich, K., Hertel, D., Homeier, J., Oelmann, Y., Olsson, P.A., Suárez, J.P. \& Rilling, M.C. (2016). Increases in Soil Aggregation Following Phosphorus Additions in a Tropical Premontane Forest are Not Driven by Root and Arbuscular Mycorrhizal Fungal Abundances. Front. Earth Sci. 3:89. doi: 10.3389/feart.2015.00089

Camenzind, T., Homeier, J., Dietrich, K., Hempel, S., Hertel, D., Krohn, A., Leuschner, C., Oelmann, Y., Olsson, P.A., Suarez, J.P. and Rillig, M.C. (2016) Opposing effects of nitrogen versus phosphorus additions on mycorrhizal fungal abundance along an elevational gradient in tropical montane forests. Soil Biology and Biochemistry 94: 37-47. doi:10.1016/j.soilbio.2015.11.011

Campo, J., \& Dirzo, R. (2003). Leaf quality and herbivory responses to soil nutrient addition in secondary tropical dry forests of Yucatán, Mexico. Journal of Tropical Ecology, 19(05), 525-530. 
Cárate-Tandalla, D., Leuscher, C., \& Homeier, J. (2015). Performance of seedlings of a shade-tolerant tropical tree species after moderate addition of $\mathrm{N}$ and $\mathrm{P}$. Frontiers in Earth Science. doi: 10.3389/feart.2015.00075.

Cavelier, J., Tanner, E., \& Santamaría, J. (2000). Effect of water, temperature and fertilizers on soil nitrogen net transformations and tree growth in an elfin cloud forest of Colombia. Journal of Tropical Ecology, 16(01), 83-99.

Ceccon, E., Huante, P., \& Campo, J. (2003). Effects of nitrogen and phosphorus fertilization on the survival and recruitment of seedlings of dominant tree species in two abandoned tropical dry forests in Yucatán, Mexico. Forest ecology and management, 182(1), 387-402.

Ceccon, E., Sánchez, S., \& Campo, J. (2004). Tree seedling dynamics in two abandoned tropical dry forests of differing successional status in Yucatán, Mexico: a field experiment with $\mathrm{N}$ and $\mathrm{P}$ fertilization. Plant Ecology, 170(2), 277-285.

Clark, D. B. \& Clark, D. A. (1985). Seedling dynamics of a tropical tree: Impacts of herbivory and meristem damage. Ecology 66: 1884-1892.

Cleveland, C. C., \& Townsend, A. R. (2006). Nutrient additions to a tropical rain forest drive substantial soil carbon dioxide losses to the atmosphere. Proceedings of the National Academy of Sciences, 103(27), 10316-10321.

Coley, P.D. (1983). Herbivory and Defensive Characteristics of Tree Species in a Lowland Tropical Forest. Ecological Monographs, Vol53, No. 2: 209-234.

Coley, P.D. \& Barone, J.A. (1996). Herbivory and plant defenses in tropical forests. Annu.Rev. Ecol.Syst.27:305-335.

Comita, L.S. \& Hubbell, S.P. (2009). Local neighborhood and species' shade tolerance influence survival in a diverse seedling bank. Ecology 90(2): 328-334.

Connell, J. H., Tracey J.G., \& Webb, L.(1984). Compensatory Recruitment, Growth and Mortality as factors maintaining rain forest tree diversity. Ecological Monographs. 54(2): 1441-164.

Coomes, D. A., \& Grubb, P. J. (1998). Responses of juvenile trees to above-and belowground competition in nutrient-starved Amazonian rain forest. Ecology, 79(3), 768-782.

Davidson, E. A., Reis de Carvalho, C. J., Vieira, I. C., Figueiredo, R. D. O., Moutinho, P., Yoko Ishida, F., et 1., \& Tuma Sabá, R. (2004). Nitrogen and phosphorus limitation 
of biomass growth in a tropical secondary forest. Ecological Applications, 14(sp4), 150-163.

Dent, D. H., \& Burslem, D. F. (2009). Performance trade-offs driven by morphological plasticity contribute to habitat specialization of Bornean tree species. Biotropica, 41(4), 424-434.

Denslow, J. S., Vitousek, P. M., \& Schultz, J. C. (1987). Bioassays of nutrient limitation in a tropical rain forest soil. Oecologia, 74(3), 370-376.

Denslow, J. S., Schultz, J. C., Vitousek, P. M., \& Strain, B. R. (1990). Growth responses of tropical shrubs to treefall gap environments. Ecology, 71(1), 165-179.

Dietrich, K., Spoeri, E. \& Oelmann, Y. (2016). Nutrient addition modifies phosphatase activities along an altitudinal gradient in tropical montane forest in Southern Ecuador. Front. Earth Sci. 4:12. doi: 10.3389/feart.2016.00012

Eichhorn, M. P., Compton, S. G., \& Hartley, S. E. (2006). Seedling species determines rates of leaf herbivory in a Malaysian rain forest. Journal of Tropical Ecology, 22(05), 513519.

Eichhorn, M. P., Nilus, R., Compton, S. G., Hartley, S. E., \& Burslem, D. F. (2010). Herbivory of tropical rain forest tree seedlings correlates with future mortality. Ecology, 91(4), 1092-1101.

Elser, J. J., Bracken, M. E., Cleland, E. E., Gruner, D. S., Harpole, W. S., Hillebrand, H., Ngal, J. T., Seabloom, E. W., Shurin, J. B. \& Smith, J. E. (2007). Global analysis of nitrogen and phosphorus limitation of primary producers in freshwater, marine and terrestrial ecosystems. Ecology letters, 10(12), 1135-1142.

Emck, P. (2007). A climatology of South Ecuador with special focus on the major Andean ridge as Atlantic-Pacific Climate divide. PhD thesis, University of Erlangen, Germany.

Ericsson, T. (1995). Growth and shoot: root ratio of seedlings in relation to nutrient availability. Plant and soil 168-169: 205-214.

Fabian, P., Kohlpaintner, M. \& Rollebck, R. (2005). Biomass burning in the Amazonfertilizer for the mountainous rain forests in Ecuador. ESPR-Environmental Science \& Pollution Research, 12(5), 290-296.

Fetcher, N., Haines, B. L., Cordero, R. A., Lodge, D. J., Walker, L. R., Fernandez, D. S., \& Lawrence, W. T. (1996). Responses of tropical plants to nutrients and light on a landslide in Puerto Rico. Journal of Ecology, 331-341. 
Fine, P. V., Mesones, I., \& Coley, P. D. (2004). Herbivores promote habitat specialization by trees in Amazonian forests. Science 305, 663-665.

Fine, P.V.A, Miller, Z.J., Mesones, I., Irazuzta, S., Apperl H.M., Stevens, M.H.H., Sääksjärvi, I., Schultz, J.C. \& Coley, P.D. (2006). The growth-defende trade-off and habitat specialization by plants in Amazonian forests. Ecology 87(7): S150-S162.

Fisher, J.B., Malhi, Y., Cuba Torres, I., Metcalfe, D.B., van den Weg, M.J., Meir, P., SilvaEspejo, J.E. \& Huaraca Huaso, W. (2013). Nutrient limitation in rainforests and cloud forests along a 3000 m. elevation gradient in the Peruvian Andes. Oecologia 172:889902.

Frazer, G. W., Canham, C. D., \& Lertzman, K. P. (1999). Gap light analyzer (GLA), Version 2.0: Imaging software to extract canopy structure and gap light transmission indices from true-color fisheye photographs, user's manual and program documentation. Copyright 1999: Simon Fraser University, Burnaby, British Columbia, and the Institute of Ecosystem Studies, Millbrook, Nek York.

Fournier, D. A., Skaug, H. J., Ancheta, J., Ianelli, J., Magnusson, A., Maunder, M., Nielsen, A. \& Sibert, J. (2012). AD Model Builder: using automatic differentiation for statistical inference of highly parameterized complex nonlinear models. Optimization Methods and Software, 27(2), 233-249.

Gamboa, A. M., Hidalgo, C., De León, F., Etchevers, J. D., Gallardo, J. F., \& Campo, J. (2010). Nutrient Addition Differentially Affects Soil Carbon Sequestration in Secondary Tropical Dry Forests: Early- versus Late- Succession Stages. Restoration Ecology, 18(2), 252-260.

Galloway, J. N., Townsend, A. R., Erisman, J. W., Bekunda, M., Cai, Z., Freney, J. R., ... \& Sutton, M. A. (2008). Transformation of the nitrogen cycle: recent trends, questions, and potential solutions. Science, 320(5878), 889-892.

Garwood, N.C. (1996). Chapter 3. Functional morphology of tropical tree seedlings. In: Swaine (Eds.) The Ecology of tropical forest tree seedlings. Volume 17. The Parthenon Publishing Group.UK. pp: 59-121.

Garwood, N.C. (2009). Seedlings of Barro Colorado Island and the Neotropics. Cornell University Press. New York, The United States of America. 
Giardina, C. P., Binkley, D., Ryan, M. G., Fownes, J. H., \& Senock, R. S. (2004). Belowground carbon cycling in a humid tropical forest decreases with fertilization. Oecologia, 139(4), 545-550.

Goodale, U. M., Berlyn, G. P., Gregoire, T. G., Tennakoon, K. U., \& Ashton, M. S. (2014). Differences in survival and growth among tropical rain forest pioneer tree seedlings in relation to canopy openness and herbivory. Biotropica, 46(2), 183-193

Graefe, S., Hertel, D., \& Leuschner, C. (2010). N, P and K limitation of fine root growth along an elevation transect in tropical mountain forests. Acta Oecologica, 36(6), 537542.

Gruber, N., \& Galloway, J. N. (2008). An Earth-system perspective of the global nitrogen cycle. Nature, 451(7176), 293-296.

Gunatilleke, C. V. S., Gunatilleke, I. A. U. N., Perera, G. A. D., Burslem, D. F. R. P., \& Ashton, P. M. S. (1997). Responses to nutrient addition among seedlings of eight closely related species of Shorea in Sri Lanka. Journal of Ecology, 301-311.

Güsewell, S. (2004). N:P ratios in terrestrial plants: variation and functional significance. New Phytologist 164: 243-266.

Harpole, W. S., Ngai, J. T., Cleland, E. E., Seabloom, E. W., Borer, E. T., Bracken, M. E., Elser, J. J., Gruner, D. S., Hillebrand, H., Shurin, J. B. \& Smith, J. E. (2011). Nutrient co-limitation of primary producer communities. Ecology Letters, 14(9), 852-862.

Harms, K.E., Condit, R., Hubbell, S.P. \& Foster, R.B.(2001). Habitata associations of tree and shrubs in a 50-ha neotropical forest plot. Journal of Ecology 89: 947-959.

Haug, I., Lempe, J., Homeier, J., Weiß, M., Setaro, S., Oberwinkler, F. \& Kottke, I. (2004) Graffenrieda emarginata (Melastomataceae) forms mycorrhizas with Glomeromycota and with a member of the Hymenoscyphus ericae aggregate in the organic soil of a neotropical mountain rain forest. Canadian Journal of Botany 82(3):340-356.

Hermans, C., Hammond, J.P. White, P.J. \& Verbruggen, N. (2006). How do plants respond to nutrient shortage by biomass allocation?. Trends in Plant Science 11: 610-617.

Lambers, J. H. R., Clark, J.S. \& Beckage, B. (2002). Density-dependent mortality and the latitudinal gradient in spscies diversity. Nature 417:732-735.

Hoegberg, P., Fan, H., Quist, M., Binkley, D. A. N., \& Tamm, C. O. (2006). Tree growth and soil acidification in response to 30 years of experimental nitrogen loading on boreal forest. Global Change Biology, 12(3), 489-499. 
Hoffmann, W. \& Poorter, H. (2002). Avoiding Bias in Calculations of Relative Growth Rate.Annals of Botany 80: 37-42.

Holste, E. K., Kobe, R. K. \& Vriesendorp, C. F. (2011). Seedling growth responses to soil resources in the understory of a wet tropical forest. Ecology 92(9): 1828 - 1838.

Homeier, J., Werner, F. A., Gradstein, S. R., Breckle, S. -W. \& Richter, M. (2008). Potential vegetation and floristic composition of Andean forests in South Ecuador, with a focus on the RBSF. In: Beck, E., Bendix, J., Kottke, I., Makeschin, F. \& Mosandl, R. (Eds.), Gradients in a Tropical Mountain Ecosystem of Ecuador. Ecological Studies, vol. 198. Springer, Berlin, Heidelberg, pp. 87-100.

Homeier, J., Breckle, S. W., Günter, S., Rollenbeck, R. T., \& Leuschner, C. (2010). Tree Diversity, Forest Structure and Productivity along Altitudinal and Topographical Gradients in a Species-Rich Ecuadorian Montane Rain Forest. Biotropica, 42(2), 140148.

Homeier, J., Hertel, D., Camezid, T., Cumbicus, N. L., Maraun, M., Martinson, G., Poma, L.N., Rilling, M.C., Sandmann, D., Scheu, S., Veldkamp, E., Wilcke, W., Wullaert, H. \& Leuschner, C. (2012). Tropical Andean Forests are highly susceptible to nutrient inputs- Rapid effects of experimental $\mathrm{N}$ and $\mathrm{P}$ addition to an Ecuadorian montane forest. PLoS One 7(10): e47128.

Homeier, J., Leuschner, C., Bräuning, A., Cumbicus, N. L., Hertel, D., Martinson, G. O., Spannl, S \& Veldkamp, E. (2013). Chapter 23 Effects of Nutrient Addition on the Productivity of Montane Forests and Implications for the Carbon Cycles. In: Bendix, J., Beck, E., Bräuning, F. M., Mosandl, R., Scheu, S. (Eds.). Ecosystem services, biodiversity and environmental change in a tropical Mountain Ecosystem of South Ecuador, vol. 221. Ecological Studies, Springer, Heidelberg. Pp: 315-329.

Horton, T. R., \& Van Der Heijden, M. G. A. (2008). The role of symbioses in seedling establishment and survival. Seedling ecology and evolution. Cambridge University Press, Cambridge, 189-213.

Hothorn, T., Bretz, F., \& Westfall, P. (2008). Simultaneous Inference in General Parametric Models. Biometrical Journal 50(3), 346-363.

Houlton B.Z., Wang, Y.P., Vitousek, P.M. \& Field C.B. (2008). A unifying framework for dinitrogen fixation in the terrestrial biosphere. Nature 454: 317-330. 
Huante, P., Rincón, E., \& Acosta, I. (1995a). Nutrient availability and growth rate of 34 woody species from a tropical deciduous forest in Mexico. Functional Ecology, 849858.

Huante, P., Rincón, E., \& Chapin III, F. S. (1995b). Responses to phosphorus of contrasting successional tree-seedling species from the tropical deciduous forest of Mexico. Functional Ecology, 760-766.

Hubbell, S. P. \& Foster, R. B. (1986). Biology, chance and history and the structure of tropical rain forest tree communities. in J. M. Diamond and T. J. Case, eds., Community Ecology. Harper and Row, NY., pp314-329.

Hyvönen, R., Ågren, G. I., Linder, S., Persson, T., Cotrufo, M. F., Ekblad, A., et al. \& Wallin, G. (2007). The likely impact of elevated [CO2], nitrogen deposition, increased temperature and management on carbon sequestration in temperate and boreal forest ecosystems: a literature review. New Phytologist, 173(3), 463-480.

Johnson, N.C. (2010) Resource stoichiometry elucidates the structure and function of arbuscular mycorrhizas across scales. New Phytologist 185(3): 631-647.

Joy Massad, T. (2013). Ontogenetic differences of herbivory on woody and herbaceous plants: a meta-analysis demonstrating unique effects of herbivory on the young and the old, the slow and the fast. Oecología 173: 1-10.

Kitajima, K. (1996). Ecophysiology of Tropical tree seedlings. In: S. Mulkey, R. Chazdon and A. Smith (Eds.) Tropical Forest Plant Ecophysiology. 559-596. Chapman and Hall, NY.

Kitajima, K. \& Fenner, M. (2000). Ecology of seedlings regeneration. In: Fenner M. (Eds.) Seeds: the ecology regeneration in plant communities. 2nd Edition. CABI. London, UK. Pp: 331-359.

Kitajima, K. (2007). Seed and Seedlins Ecology. In: pugnaire, F. \& Valladares, F. (eds). Functional Plant Ecology. CRC Press, USA. Pp: 549-579.

Kitajima, K. \& Myers, J.A. (2008). Seedling ecophysiology: strategies toward achievement of positive net carbon balance. In: Leck, M.A., Parker, V.T. \& Simpson, R.L. (eds). Seedling ecology and evolution. Cambridge University Press, UK: 172-188.

Kitajima, K. \& Poorter, L. (2008). Functional basis for resource niche partitioning by tropical trees. In: Schnitzer, S.A. and Carson, W.P. (eds.) Tropical Forest Community Ecology, Blackwell Science, Pp. 160-181. 
Kitajima, K. \& Poorter, L. (2010). Tissue-level leaf toughness, but not lamina thickness, predicts sapling leaf lifespan and shade tolerance of tropical tree species. New Phytologist 186: 708-721.

Kitajima, K., Cordero, R. A., \& Wright, S. J. (2013). Leaf life span spectrum of tropical woody seedlings: effects of light and ontogeny and consequences for survival. Annals of botany, 112(4), 685-699.

Koerselman, W., \& Meuleman, A. (1996). The vegetation N:P ratio: a new tool to detect the nature of nutrient limitation. Journal of Applied Ecology 33: 1441-1450.

Kobe, R. K. (1999). Light gradient partitioning among tropical tree species through differential seedling mortality and growth. Ecology 80(1): 187-201.

Kottke, I., Beck, A., Oberwinkler, F., Homeier, J. and Neill, D. (2004) Arbuscular endomycorrhizas are dominant in the organic soil of a neotropical montane cloud forest. Journal of Tropical Ecology 20:125-129.

Kottke, I., Beck, A., Haug, I., Setaro, S., Jeske, V., Suárez, J. P., ... \& Oberwinkler, F. (2008). Mycorrhizal state and new and special features of mycorrhizae of trees, ericads, orchids, ferns, and liverworts. Ecological Studies, 198, 137.

Krashevska, V., Sandmann, D., Maraun, M., \& Scheu, S. (2014). Moderate changes in nutrient input alter tropical microbial and protist communities and belowground linkages. The ISME journal, 8(5), 1126-1134.

Kueffer, C., Schumacher, E., Fleischmann, K., Edwards, P. J., \& Dietz, H. (2007). Strong below-ground competition shapes tree regeneration in invasive Cinnamomum verum forests. Journal of Ecology, 95(2), 273-282.

Lawrence, D. (2001). Nitrogen and phosphorus enhance growth and luxury consumption of four secondary forest tree species in Borneo. Journal of Tropical Ecology, 17(06), 859869.

Lawrence, D. (2003). The response of tropical tree seedlings to nutrient supply: meta-analysis for understanding a changing tropical landscape. Journal of Tropical Ecology, 19(03), 239-250.

Leuschner, C., Moser, G., Bertsch, C., Röderstein, M., \& Hertel, D. (2007). Large altitudinal increase in tree root/shoot ratio in tropical mountain forests of Ecuador. Basic and Applied Ecology, 8(3), 219-230. 
LeBauer, D. S., \& Treseder, K. K. (2008). Nitrogen limitation of net primary productivity in terrestrial ecosystems is globally distributed. Ecology, 89(2), 371-379.

Lewis, S. L., \& Tanner, E. V. (2000). Effects of above-and belowground competition on growth and survival of rain forest tree seedlings. Ecology, 81(9), 2525-2538.

Lieberman, D., Lieberman, M., Peralta, R. \& Hartshorn, G.S. (1996) Tropical forest structure and composition on a large-scale altitudinal gradient in Costa Rica. Journal of Ecology 1996, 84, 137-152.

Long, W., Zang, R., Schamp, B.S. \& Ding, Y. (2011). Within-and among species variation in specific leaf area drive community assembly in a tropical cloud forest. Oecologia 167: 1103-1113.

Lu, X., Mo, J., Gilliam, F. S., Zhou, G., \& Fang, Y. (2010). Effects of experimental nitrogen additions on plant diversity in an old-growth tropical forest. Global Change Biology, 16(10), 2688-2700.

Luque, G. M., Hochberg, M. E., Holyok, M., Hossaert, M., Gaill, F., \& Courchamp, F. (2013). Ecological Effects of environmental change. Ecology Letter, 16:1-3.

Magill, A. H., Aber, J. D., Currie, W. S., Nadelhoffer, K. J., Martin, M. E., McDowell, W. H., et al. \& Steudler, P. (2004). Ecosystem response to 15 years of chronic nitrogen additions at the Harvard Forest LTER, Massachusetts, USA. Forest Ecology and Management, 196(1), 7-28.

Mahowald, N. M., Artaxo, P., Baker, A. R., Jickells, T. D., Okin, G. S., Randerson, J. T. et al. (2005) Impacts of biomass burning emissions and land use change on Amazonian atmospheric phosphorus cycling and deposition. Global Biogeochemical Cycles 19: GB4030.

Martinson, G. O., Corre, M. D., \& Veldkamp, E. (2013). Responses of nitrous oxide fluxes and soil nitrogen cycling to nutrient additions in montane forests along an elevation gradient in southern Ecuador. Biogeochemistry, 112(1-3), 625-636.

Marschner, H. (1995). Mineral nutrition of higher plants. Academic Press, London.

Matson, A. L., Corre, M. D., \& Veldkamp, E. (2014). Nitrogen cycling in canopy soils of tropical montane forests responds rapidly to indirect $\mathrm{N}$ and $\mathrm{P}$ fertilization. Global change biology, 20(12), 3802-3813.

Matson, A. (2014). Canopy soil nutrient cycling and responses to elevated nutrient levels along an elevation gradient of tropical montane forest. Dissertation zur Erlangung des 
Doktorgrades der Mathematisch-Naturwissenschaftlichen Fakultäten der GeorgAugust-Universität Göttingen, Deutschland.

Matson A.L., Corre M.D., Burneo, J.L. \& Veldkamp, E. (2015). Free-living nitrogen fixation responds to elevated nutrient inputs in tropical montane forest floor and canopy soils of southern Ecuador. Biogeochemistry 122: 281-294.

Markesteijn, L., \& Poorter, L. (2009) Seedling root morphology and biomass allocation of 62 tropical tree species in relation to drought- and shade- tolerance. Journal of Ecology, 97: 311-325.

Mayor, J. R., Wright, S. J., \& Turner, B. L. (2014). Species- specific responses of foliar nutrients to long-term nitrogen and phosphorus additions in a lowland tropical forest. Journal of Ecology, 102(1), 36-44.

McConnaughay, K.D.M. \& Coleman, J.S. (1999). Biomass allocation in plants: Ontogeny or optimality? A test along three resources gradients. Ecology80(8): 2581-2593.

Metcalfe, D. B., Asner, G. P., Martin, R. E., Silva Espejo, J. E., Huasco, W. H., Farfán Amézquita, F. F. et al. (2014). Herbivory makes major contributions to ecosystem carbon and nutrient cycling in tropical forests. Ecology Letters, 17, 324-332.

McGonigle, T.P., Miller, M.H., Evans, D.G., Fairchild, G.L., Swan, J.A. (1990) A new method which gives an objective-measure of colonization of roots by vesiculararbuscular mycorrhizal fungi. New Phytologist 115: 495-501. doi: 10.1111/j.14698137.1990.tb00476.

Metz, M. R., Comita, L. S., Chen, Y. Y., Norden, N., Condit, R., Hubbell, S. P., ... \& Wright, S. J. (2008). Temporal and spatial variability in seedling dynamics: a cross-site comparison in four lowland tropical forests. Journal of Tropical Ecology, 24(01), 918.

Metz, M.R., Sousa, W.P. \& Valencia, R. (2010). Widespread density-dependent seedling mortality promotes species coexistence in a highly diverse Amazonian rain forest. Ecology 91(12): 3675-3685.

Metz, M.R. (2012). Does habitat specialization by seedlings contribute to the high diversity of lowland rain forests?. Journal of Ecology 100: 969-979.

Mirmanto, E., Proctor, J., Green, J., Nagy, L., \& Surintata. (1999). Effects of nitrogen and phosphorus fertilization in a lowland evergreen rainforest. Phil. Trans. R. Soc. Lond. B 354, 1825-1829. 
Mo, J., Li, D., \& Gundersen, P. (2008). Seedling growth response of two tropical tree species to nitrogen deposition in southern China. European Journal of Forest Research, 127(4), 275-283.

Mo, Q., Zou, B., Li, Y., Chen, Y., Zhang, W., Mao, R. et al. (2015) Response of plant nutrient stoichiometry to fertilization varied with plant tissues in a tropical forest. Scientific Reports 5:14605. DOI: 10.1038/srep14605.

Moser, G., Hertel, D., \& Leuschner, C. (2007). Altitudinal change in LAI and stand leaf biomass in tropical montane forests: a transect study in Ecuador and a pan-tropical meta-analysis. Ecosystems, 10(6), 924-935.

Müller, A. (2014). Soil greenhouse gas fluxes under elevated nutrient input along an elevation gradient of tropical montane forests in southern Ecuador. Dissertation thesis, Georg-August-Universität Göttingen.

Müller, A.K., Matson, A.L., Corre, M.D. \& Veldkamp, E. (2015). Soil $\mathrm{N}_{2} \mathrm{O}$ fluxes along an elevation gradient of tropical montane forests under experimental nitrogen and phosphorus addition.. Frontiers in Earth Science. doi: 10.3389/ feart/2015.00066.

Nasto, M.K., Alvarez-Clare, S., Lekberg, Y., Sullivan, B.W., Townsend, A.R. \& Cleveland, C.C. (2014). Interactions among nitrogen fixation and soil phosphorus acquisition strategies in lowland tropical rain forests. Ecology Letters 17: 1282-1289.

Norden, N., Angarita. H. A., Bongers, F., Martínez-Ramos, M., Granzow-de la Cerda, I., van Breugel, M., Lebrija-Trejos, E., Meave, J.A., Vandermeer, J., Williamson, G.B., Finegan, B., Mesquita, R. \& Chazdon, R.L. (2015). Successional dynamics in Neotropical forests are as uncertain as they are predictable. Proceedings of the National Academy of Sciences. 10.1073/pnas. 1500403112.

Norghauer, J. M., \& Newbery, D. M. (2014). Herbivores differentially limit the seedling growth and sapling recruitment of two dominant rain forest trees. Oecologia, 174(2), 459-469.

Nussbaum, R., Anderson, J., \& Spencer, T. (1995). Factors limiting the growth of indigenous tree seedlings planted on degraded rainforest soils in Sabah, Malaysia. Forest Ecology and Management, 74(1), 149-159.

Oksanen, J., Blanchet, F. G., Kindt, R., Legendre, P., Minchin, P. R., O'Hara, R. B., Simpson, G. L., Solymos, P., Stevens, M. H. H. \& Wagner, H. (2013). vegan: Community 
Ecology Package. $\mathrm{R}$ package version 2.0-10. http://CRAN.Rproject.org/package=vegan.

Ordoñez, J.C., van Bodegom, P.M., Witte, J.M., Wright, I.J., Reich, P.B. \& Aerts, R. (2009). A global study of relationships between leaf traits, climate and soil measures of nutrient fertility. Global ecology and biogeography 18: 137-149.

Ostertag, R. (2010). Foliar nitrogen and phosphorus accumulation responses after fertilizations: an example from nutrient-limited Hawaiian forests. Plant Soil 334:8598.

Ostertag, R. \& DiManno, N.M. (2016) Detecting terrestrial nutrient limitation: A global meta-analysis of foliar nutrient concentrations after fertilization. Front. Earth Sci. 4:23. doi: 10.3389/feart.2016.00023.

Paine, C.E.T., Harms, K.E., Schnitzer, S.A. and Carson, W.P. (2008) Weak competition among tropical tree seedlings: Implications for species coexistence. Biotropica 40(4): 432-440. doi: 10.1111/j.1744-7429.2007.00390.x

Paine, C.E.T, Stenflo, M., Philipson, C.D. Saner, P., Bagchi, R., Ong, R.C. \& Hector, A. (2012). Differential growth responses in seedlings of ten species of Dipterocarpaceae to experimental shading and defoliation. Journal of Tropical Ecology 28: 377-384.

Palmiotto, P. A., Davies, S. J., Vogt, K. A., Ashton, M. S., Vogt, D. J. \& Ashton, P. S. (2004). Soil-related habitat specialization in dipterocarp rain forest tree species in Borneo. Journal of Ecology 92: 609-623.

Pardo, L. H., McNulty, S. G., Boggs, J. L., \& Duke, S. (2007). Regional patterns in foliar 15 $\mathrm{N}$ across a gradient of nitrogen deposition in the northeastern US. Environmental pollution, 149(3), 293-302.

Pasquini, S. C., \& Santiago, L. S. (2012). Nutrients limit photosynthesis in seedlings of a lowland tropical forest tree species. Oecologia, 168(2), 311-319.

Paz, H. (2003). Root:shoot Allocation and Root Architecture in Seedlings: Variation among Forest Sites, Microhabitats, and Ecological Groups1. Biotropica, 35(3), 318-332.

Pennington, T. D. (2007). Sapotaceae. Flora of Ecuador. Department of Plant and Environmental Sciences, Göteborg University. Göteborg, Sweden.

Peñuelas, J., Poulter, B., Sardans, J., Ciais, P., van der Velde, M., Bopp, L. et al.(2013) Human-induced nitrogen-phosphorus imbalances alter natural and managed ecosystems across the globe. Nature Communications 4:2934. 
Phillips, J.M., Hayman, D.S., 1970. Improved procedures for clearing roots and staining parasitic and vesicular-arbuscular mycorrhizal fungi for rapid assessment of infection. Transactions of the British Mycological Society 55:158-161.

Philipson, C. D., Dent, D. H., O'Brien, M. J., Chamagne, J., Dzulkifli, D., Nilus, R., Philips, S., Reynolds, G., Saner, P. \& Hector, A. (2014). A trait-based trade-off between growth and mortality: evidence from 15 tropical tree species using size-specific relative growth rates. Ecology and evolution, 4(18), 3675-3688.

Pinheiro, J., Bates, D., DebRoy, S., Sarkar, D. \& R Core Team (2014). _nlme: Linear and Nonlinear Mixed Effects Models_. R package version 3.1-117, <URL: http://CRAN.Rproject.org/package $=$ nlme $>$.

Poorter, H. \& Remkes, C. (1990). Leaf area ratio and net assimilation rate of 24 wild species differing in relative growth rate. Oecologia 83: 553-559.

Poorter, H. and Evans, J.R. 1998. Photosynthetic nitrogen-use efficiency of species that differ inherently in specific leaf area. Oecologia 116: 26-37.

Poorter, H. \& Nagel, O. (2000). The role of biomass allocation in the growth response of plants to different levels of light, $\mathrm{CO} 2$, nutrients and water: a quantitative review. Aust. J. Plant Physiol. 27, 595-607.

Poorter, L. (2005). Resource capture and use by tropical forest tree seedlings and their consequences for competition. In: Burslem, D., Pinard, M. \& Hartley, S. (eds). Biotic interactions in the tropics: The role in the maintenance of species diversity. Cambridge University Press. Pp: 35-64.

Poorter, L., \& Bongers, F. (2006). Leaf traits are good predictors of plant performance across 53 rain forest species. Ecology, 87(7), 1733-1743.

Poorter, L. \& Markesteljn, L. (2008). Seedlings traits determine drought tolerance of tropical species. Biotropica 40(3): 321-331.

Poorter, H., Niklas, K. J., Reich, P. B., Oleksyn, J., Poot, P., \& Mommer, L. (2012). Biomass allocation to leaves, stems and roots: meta-analyses of interspecific variation and environmental control. New Phytologist, 193(1), 30-50.

Poorter, H. \& Sack, L.(2012) Pitfalls and possibilities in the analysis of biomass allocation patterns in plants. Frontiers in Plant Science. Vol.3. 259: 1-10. 
Press, M. C., Brown, N. D., Barker, M. G., \& Zipperlen, S. W. (1996). Photosynthetic responses to light in tropical rain forest tree seedlings. Man and the Biosphere Series, $17,41-58$.

Queenborough, S., Burslem, D. F. R. P., Garwood, N., \& Valencia, R. (2007). Neighborhood and community interactions determine the spatial pattern of tropical tree seedling survival. Ecology 88(9): 2248-2258.

Raaimakers, D., \& Lambers, H. (1996). Response to phosphorus supply of tropical tree seedlings: a comparison between a pioneer species Tapirira obtusa and a climax species Lecythis corrugata. New Phytologist, 132(1), 97-102.

R Core Team. (2013). R: A language and environment for statistical computing. R Foundation for Statistical Computing, Vienna, Austria. URL http://www.Rproject.org/.

R Core Team (2014). R: A language and environment for statistical computing. R Foundation for Statistical Computing, Vienna, Austria. URL http://www.R-project.org/.

Richter, M., Beck, E., Rollenbeck, R. \& Bendix, J. (2013). Chapter 1. The Study Area. In: Bendix, J., Beck, E., Bräuning, A., Makeschin, F., Mosandl, R., Scheu, S., and Wilcke, W. (Eds.). Ecosystems services, Biodiversity and Environmental Change in a tropical mountain ecosystem of south Ecuador. Ecological Studies 221. Springer. Berlin. Pp: 315- 329.

Salinas-Peba, L., Parra-Tabla, V., Campo, J., \& Munguía-Rosas, M. A. (2014). Survival and growth of dominant tree seedlings in seasonally tropical dry forests of Yucatan: site and fertilization effects. Journal of Plant Ecology, 7(5), 470-479.

Santiago, L. S., Wright, S. J., Harms, K. E., Yavitt, J. B., Korine, C., Garcia, M. N., \& Turner, B. L. (2012). Tropical tree seedling growth responses to nitrogen, phosphorus and potassium addition. Journal of Ecology, 100(2), 309-316.

Schreeg, L. A., Santiago, L. S., Wright, S. J., \& Turner, B. L. (2014). Stem, root, and older leaf $\mathrm{N}$ : $\mathrm{P}$ ratios are more responsive indicators of soil nutrient availability than new foliage. Ecology, 95(8), 2062-2068.

Skaug, H. Fournier, D., Bolker, B., Magnusson, A. \& Nielsen, A. (2014). Generalized Linear Mixed Models using AD Model Builder_. R package version 0.8.0.

Sterner, R. W. \& Elser, J.J. (2002). Ecological Stoichiometry. The biology of elements from molecules to the biosphere. Princeton University Press. USA.Pp:80-82. 
Svenning, J. C., Fabbro, T., \& Wright, S. J. (2008). Seedling interactions in a tropical forest in Panama. Oecologia, 155(1), 143-150.

Swaine, M. D. (1996). Rainfall and soil fertility as factors limiting forest species distributions in Ghana. Journal of Ecology, 419-428.

Tanner, E. V. J., Kapos, V., Freskos, S., Healey, J. R., \& Theobald, A. M. (1990). Nitrogen and phosphorus fertilization of Jamaican montane forest trees. Journal of Tropical Ecology, 6(02), 231-238.

Tanner, E.V.J. \& Kapos, V. (1992). Nitrogen and phosphorus fertilization effects on Venezuelan montane forest truck growth and litterfall. Ecology 73 (1): 78-86.

Tanner, E.V.J., Vitousek, P.M. \& Cuevas, E. (1998). Experimental investigation of nutrient limitation of forest growth on wet tropical mountains. Ecology 79 (1): 10-22.

Tessier, J.T. \& Raynal, D.J.(2003). Use of nitrogen to phosphorus ratios in plant tissue as an indicator of nutrient limitation and nitrogen saturation. Journal of Applied Ecology 40: 523-534.

Thompson, W. A., Huang, L. K., \& Kriedemann, P. E. (1992). Photosynthetic response to light and nutrients in sun-tolerant and shade-tolerant rainforest trees. II. Leaf gas exchange and component processes of photosynthesis. Functional Plant Biology, 19(1), $19-42$.

Townsend, A. R., Cleveland, C. C., Asner, G. P., \& Bustamante, M. M. (2007). Controls over foliar N: P ratios in tropical rain forests. Ecology, 88(1), 107-118.

Townsend, A.R., Asner, G.P. \& Cleveland, C.C. (2008). Trends in Ecology and Evolution. Vol.23,No.8: 424-431.

Treseder, K.K. \& Vitousek, P.M. (2001). Effects of soil nutrient availability on investments in acquisition of $\mathrm{N}$ and $\mathrm{P}$ in Hawaiian rain forests. Ecology 82(4): 946-954.

Turner, I.M. (1991). Effects of shade and fertilizer addition on the seedlings of two tropical wood pioneer species. Tropical Ecology 32(1): 24-29.

Turner, I. M., Brown, N. D., \& Newton, A. C. (1993). The effect of fertilizer application on dipterocarp seedling growth and mycorrhizal infection. Forest Ecology and Management, 57(1), 329-337.

Turner, I. M. (2001). The Ecology of Trees in Tropical Rain Forest. Cambridge University press. Cambridge, United Kingdom. 
Turner, I.M. (2002). The Ecology of Trees in the Tropical Rain Forest. Cambridge University Press. pp: $180-226$.

Unger, M., Leuschner, C. \& Homeier, J.(2010). Variability of indices of macronutrient availability in soils at different spatial scales along an elevation transect in tropical moist forests (NE Ecuador). Plant and Soil, 336, 443-458.

Vitousek, P. M., \& Farrington, H. (1997). Nutrient limitation and soil development: experimental test of a biogeochemical theory. Biogeochemistry, 37(1), 63-75.

Vitousek, P. M., Porder, S., Houlton, B. Z., \& Chadwick, O. A. (2010). Terrestrial phosphorus limitation: mechanisms, implications, and nitrogen-phosphorus interactions. Ecological applications, 20(1), 5-15.

Vincent, A. G., \& Tanner, E. V. (2013). Major litterfall manipulation affects seedling growth and nutrient status in one of two species in a lowland forest in Panama. Journal of Tropical Ecology, 29(05), 449-454.

Walker, A.P., Beckerman, A.P., Gu, L., Kattge, J., Cernusak, L.A., Domingues, T.F et al. (2014). The relationship of leaf photosynthetic traits-Vcmax and Jmax-to leaf nitrogen, leaf phosphorus, and specific leaf area: a meta-analysis and modeling study. Ecology and Evolution, 4(16), 3218-3235.

Wan Juliana, W., Burslem, D. F., \& Swaine, M. D. (2009). Nutrient limitation of seedling growth on contrasting soils from Pasoh Forest Reserve, Peninsular Malaysia. Journal of tropical forest science, 316-327.

Webb, C.O. \& Peart, D.R. (2000). Habitat associations of tress and seedlings in a Bornean rain forest. Journal of Ecology 88: 464-478.

Werner, F. A. \& Homeier, J. (2015). Is tropical montane forest heterogeneity promoted by a resource-driven feedback cycle? Evidence from nutrient relations, herbivory and litter decomposition along a topographical gradient. Functional Ecology. 29(3), 430-440.

Whitmore, T. C. (1996). A review of some aspects of tropical rain forest seedling ecology with suggestions for the further enquiry. In: Swaine, M. D.(ed.) The ecology of tropical forest tree seedling. Man and biosphere series, Vol. 17. UNESCO, Paris., 339.

Wilcke, W., Yasin, S., Abramowski, U., Valarezo, C., \& Zech, W. (2002). Nutrient storage and turnover in organic layers under tropical montane rain forest in Ecuador. Europ $\mathbf{J}$ Soil Sci 53: 15-27. 
Wilcke, W., Leimer, S., Peters, T., Emck, P., Rollenbeck, R., Trachte, K., Valarezo, C. \& Bendix, J. (2013). The nitrogen cycle of tropical montane forest in Ecuador turns inorganic under environmental change. Global Biogeochem. Cycles 27, 1194-1204.

Wittich, B., Homeier, J., \& Leuschner, C. (2014). Ammonium, nitrate and glycine uptake of six Ecuadorian tropical montane forest tree species: an in situ pot experiment with saplings. Journal of Tropical Ecology, 1-14.

Wolf, K., Veldkamp, E., Homeier, J., \& Martinson, G. O. (2011). Nitrogen availability links forest productivity, soil nitrous oxide and nitric oxide fluxes of a tropical montane forest in southern Ecuador. Global Biogeochemical Cycles, 25(4).

Wright, I. J., \& Westoby, M. (1999). Differences in seedling growth behavior among species: trait correlations across species, and trait shifts along nutrient compared to rainfall gradients. Journal of Ecology, 87(1), 85-97.

Wright, I. J., \& Westoby, M. (2000). Cross-species relationships between seedling relative growth rate, nitrogen productivity and root vs leaf function in 28 Australian woody species. Functional Ecology, 14(1), 97-107.

Wright, I.J. \& Westoby, M. (2001). Understanding seedling growth relationships through specific leaf area and Leaf nitrogen concentration: generalizations across growth forms and growth irradiance. Oecologia 127: 21-19.

Wright, S.J., (2002). Plant diversity in tropical forest: a review of mechanisms of species coexistence. Oecologia 130:1-14. doi:10.1007/s004420100809.

Wright, S. J. (2005). Tropical forests in a changing environment. Trends in Ecology \& Evolution, 20(10), 553-560.

Wright, S. J., Kitajima, K., Kraft, N. J., Reich, P. B., Wright, I. J., Bunker, D. E., et al. (2010). Functional traits and the growth-mortality trade-off in tropical trees. Ecology, 91(12), 3664-3674.

Wright, S. J., Yavitt, J. B., Wurzburger, N., Turner, B. L., Tanner, E. V., Sayer, E. J., ... \& Corre, M. D. (2011). Potassium, phosphorus, or nitrogen limit root allocation, tree growth, or litter production in a lowland tropical forest. Ecology, 92(8), 1616-1625.

Wullaert, H., Homeier, J., Valarezo, C., \& Wilcke, W. (2010). Response of the N and P cycles of an old-growth montane forest in Ecuador to experimental low-level $\mathrm{N}$ and $\mathrm{P}$ amendments. Forest Ecology and Management 260: 1434-1445. 
References

Xia, J., \& Wan, S. (2008). Global response patterns of terrestrial plant species to nitrogen addition. New Phytologist, 179(2), 428-439.

Yavitt, J. B., \& Wright, S. J. (2008). Seedling growth responses to water and nutrient augmentation in the understory of a lowland moist forest, Panama. Journal of Tropical Ecology, 24(01), 19-26.

Zalamea, P.C., Turner, B.L., Winter, K., Jones, F.A., Sarmiento, C. and Dalling, J.W. (in press) Seedling growth responses to phosphorus reflect adult distribution patterns of tropical trees. New Phytologist. doi 10.1111/nph.14045

Zangerl, A.R., Hamilton, J.G., Miller, T.J., Crofts, A.R., Oxborough, K., Berenabum, M.R. \& de Lucia, E.H. (2002). Impact of folivory on photosynthesis is greater than the sum of its holes. PNAS vol.99, no.2, 1088-1091.

Zuur, Alain F., Ieno, E. N., Walker, N. J., Saveliev, A. A. \& Smith, G. H. (2009). Mixed effects models and extensions in ecology with R. Springer. NY, USA. Pp: 101- 142. 


\section{ACKNOWLEDGMENTS}

This dissertation was possible thanks to the unconditional support, collaboration and advise of Dr. Jürgen Homeier to whom I am truly grateful for working together with me from the very beginning of this project until the final period in every report, document and publication during the last four years. Many thanks to Prof. Dr. Christoph Leuschner for his support and advice during the work on this dissertation.

I am very grateful to Roman Link for sharing with me his mathematical talents and friendship during all those long journeys gathering with stats and "R". I want also to say "Thanks you very much" to Dr. Simon Queenborough for always giving me some time to read and advise my junior science and to Dr. Florian Werner for helping me to connect ideas and concepts.

I gratefully acknowledge the financial support of the Deutsche Akademischer Austauchdients (DAAD) during the four years of my doctorate studies in Germany and the Deutsche Forschungsgesellschaft (DFG) as part of the project A1 in the research unit 816. In Ecuador, I am grateful to the "Ministerio del Ambiente" for granting research permits and the "local government of the Loja province" for facilitating the seedlings and seeds for the experiments.

Many students, assistants and volunteers among Germans and Ecuadorians helped me during the fieldwork excursions at the tropical montane forests. I want to give my appreciation for the nice company and hardworking partnership of Marlene Kroner, Adrian Thiele, María López, Jaime Peña, Nelson Jaramillo and Patricio Salas for all journeys camping, walking, working and talking in the forests. A huge “iDios les Pague mis Wambritas!” to my lovely sister Sil Cárate Tandalla and friends Mayra Ninazunta and Stephany Vega for joining the team during short time to visit me and/or hanging out together while we measured seedlings. I want also to recognize the strength and happy spirit of the small battalion which helped me to carry more than 1200 seedlings from the ECSF up to the mountain, "Sí se puede, Sí se puede".

All the logistics and transportations were in charge of the staff of the San Francisco station to which I would like to say thanks. The drivers Taty, Abraham and Robert, the station crew Rocío Aguirre and María Feijoo. Also to Nohemy Poma for facilitating material and extra hard-working assistants. Big thanks to Felix Matt and Jörg Zeilinger for managing permits, plants and sample deliveries to Germany and the ECSF.

Back to Germany, "Science Saturdays during 2012-2013" would have not been possible without the inspired ideas of the juniors Drs. Angelica Baldos, Anke Müller and Amanda Matson, members of the TMF research team, enthusiastic ex-students at the Uni Göttingen and, most 
importantly, lovely nerdy friends of mine with whom I also shared house, blocks, plots, and roads during our long journeys of field work in Ecuador.

Other students also contributed importantly to this work in Göttingen and Ecuador. I want to thank Kerstin Burns, Teresa van Aken, Marion Schmelz, Anne Bergman, Paolo Villegas and Matti Fellmann for helping me with previous monitoring assessments, hemispherical photos, herbivory analyses, grinding seedlings during long journeys and on the field harvesting seedlings.

And last but not least to my big family here and there. In Ecuador: "Gracias Totales Familia" for all support and love from Ecuador to Nelly Tandalla, Alonsito Cárate, Silvana and Edison Cárate Tandalla and Godot (-the house dog-) to bear my long absences from home and still remember, care about me and unconditionally love me.

"Danke Schön” to my friends and colleagues in Germany for all sympathy, good experiences and times together: To Yasmina Abou Rajab always sharing her positivism, good energy and clarity; a Sarah Lilian Burns por tantas largas caminatas a casa conversando y aprendiendo de nuestras vidas!, für Stefanito Meyer du bist já ein schone gute vorbildliche DDR kind, to Stefan Kaufmann Kaufi- "thank you very much!!! for became in the best rock/punk-buddy for me", to Tina Stepphen for all those nights in the poetry slams at THOP, to Maude Erasmi -I will call you from UIO to read one more "Frag doch mal...", to Bettina Wagner for introduced me to die Echte echte Liebe "black and yellow BvB"-Heja BvB, Heja BvB-, and to Christian Schöbitz for bringing back to me calm and happy smiles during the dissertation-writting process. Thanks also to all colleagues, mates and friends who have shared with me short or long remarkable good times during these four years, the Latincommunity: Jorgito Gómez, Lupita Xalapa and Suremcito, Euge and Elena Vásques, Cristina Romero, Hilario Espinoza, Margarita Cabra, Jhenny Salgado, Laurita Salazar, the European friends: Natalia Sierra (Nube), Fede Dradi (Rat), Laura Sutcliffe, Mike Egan (Irish Rat), Petra Kubish, and the local German heroes: Laura Demant, Nele Janz (Nonna), Fabian Brambach, Torben Lübbe, Marc Appelhaus and Klaus Schützenmeister. A big hug to those buddies far away in America (-the continent-) cheering me up and sending me electronic kisses and hugs, and nice postcards: Natalia Hernández (Nato), Janeth Santiana (Jane), Mónica Guerra (Monkey), Diego Alvarado (Diegueins), Sebastián Tello (Tellin) and Miguel Pinto (Miguelon), all biologists from my early years at the PUCE.

Finally, a gigantic special gratitude to Denisse Garza, Daniela García-Sánchez, Daniel Avendaño, Miguel Camacho, and my little nephew Mickey Camacho-Garza, "My unforgettable Mexican Family" for create all those amazing and significant moments together being so far away from our homes and because thanks to them I can now eat tons of "chili bravo" and "tajin". 


\title{
Dayssy M. Cárate Tandalla
}

\author{
Born on $18^{\text {th }}$ of July, 1981 in Latacunga, ECUADOR
}

\section{EDUCATION}

2011- Oct. 2015

Oct. 2005

$1999-2005$

$1993-1999$

\section{LANGUAGES}

Spanish

English

German

\section{EXPERIENCE}

2011 - present

2011

2010

$2008-2010$

2008
University of Göttingen. Department of Plant Ecology and Ecosystem

Research. PhD. candidate

Licenciatura in Biological Sciences graduation (equivalent to Diplom).

The Pontifical Catholic University of Ecuador (PUCE). Quito, Ecuador

Faculty of Exact and Natural Science. School of Biology Sciences.

"Hermano Miguel” High school. Latacunga, Ecuador

High school degree in Science: Physics and Mathematics, Informatics.

Mother tongue

English proficiency. Fulbright Commission. Quito, Ecuador

B1.2 level. Institute Goethe. Göttingen-Germany

Ph.D. Studies. Research student in NUMEX project sponsor by DFG in Ecuador. Research unit FOR 816. Group A1.

Research Scholar. Missouri Botanical Garden. Taxonomic Revision of Four Vascular Plants Genera Living in Association with Polylepis (Rosaceae) forests in Ecuador. Bascom Fellow.

Teacher. School of Biological Sciences. Faculty of Exact and Natural Sciences. PUCE. Subjects: "Systematic Botany of Ecuadorian Flora"

Member of Research Team. CONDESAN-Páramos Andinos Project. Project: "Identification of priority areas for conservation in PáramoEcosystems in Chimborazo province".

Research Assistant. Ecociencia-Páramos Andinos Project, associated with QCA Herbarium (PUCE). "Map of Páramos: Associated flora in 
$2007-2010$

$2006-2008$

$2003-2004$

OTHER RELEVANT EXPERIENCE

$2001-2004$

2003

PRESENTATIONS

Feb. 2014

Apr. 2013

Feb. 2012

Jun. 2009 PUCE. PUCE.
Polylepis forests in Ecuador."

Member of Research Team. QCA Herbarium-PUCE. Project: "Ecology and biodiversity of the Polylepis forests in the Ecuadorian Highlands."

Teacher's Assistant. School of Biological Sciences. PUCE. Subjects of Botany II and Systematic Botany of Ecuador.

Curator Assistant. QCA Herbarium. PUCE.

Botanical Field Research Assistant. School of Biological Science. PUCE. Project: "Distribution of Legume Species in two 1-HectarePlots in the Yasuní National Park, Ecuadorian Amazon." Licenciatura's thesis research.

Research Scholar. QCA Herbarium. School of Biological Science.

Research Scholar. QCAZ Museum. School of Biological Science.

"Performance of Pouteria torta (Sapotaceae) seedlings after moderate addition of $\mathrm{N}$ and $\mathrm{P}$ in a Premonate Tropical Forest in Southern Ecuador". Poster presented at the Conference of the Society for Tropical Ecology-Tropical Ecosystems-between protection and production. Freising, Germany.

"Effect of nutrient addition on the performance of tree seedlings in a tropical montane forest in Southern Ecuador" Talk presented at the Conference of the Society for Tropical Ecology -Tropical organisms and Ecosystems in a Changing World. Vienna, Austria.

"Effects pf experimental nutrient addition on the establishment and growth of Tropical Montane Forest tree species in Southern Ecuador". Poster presented at the Conference of the Society for Tropical EcologyIslands in Land-and seascape: The challenges of fragmentation. Erlangen, Germany

"Diversidad de la Flora asociada de los bosques de Polylepis (ROSACEAE) en Oyacachi, provincia de Napo" (in Spanish). Poster presented in the Second World Congress of Páramos, PARAMUNDI. Loja, Ecuador. 
Jan. 2008

"Herbariun QCA, one of the largest plant collections in Ecuador" and "Plant-Diversity and Extension of Polylepis Forest in Oyacachi" (coauthor). Poster presented in the 1st. Fulbright Symposium. Quito, Ecuador.

Nov. 2006

"Phenological Cycles of Fifteen Tree Species in One Hectare Plot in The Yasuni National Park, Ecuadorian Amazon." Talk presented at the XXX National Meeting of Biology. Quito, Ecuador.

\section{AWARDS}

DAAD Scholarship 2011-2015. Deutscher Akademischer Austausch Dienst.

Programme: "Forschungsstipedium für Doktoranden und Nachwuchwissenschatfttler".

Maria Sibylla Merian Award 2011. At the Conference of the Society for Tropical Ecology. For the third best poster presented at the conference.

Elizabeth E. Bascom Fellowship. 2010. Missouri Botanical Garden. Project awarded: "Taxonomic Revision of four Vascular plants genera associated to the Polylepis forests in Ecuador". 


\section{DECLARATION OF ORIGINALITY AND CERTIFICATE OF AUTHORSHIP}

I, Dayssy Maritza Cárate Tandalla, hereby declare that I am the sole author of this dissertation entitled: "Effects of moderate Nitrogen and Phosphorus addition on the species composition and dynamics of the tree seedlings community in tropical montane forests in Southern Ecuador“.

All quotations in this thesis have been distinguished by quotation marks, and all sources of information are acknowledged by reference to the authors.

I furthermore declare that this work has not been submitted elsewhere in any form as part of another dissertation procedure. I certify that the manuscripts presented in chapters 3,4 , and 5 have been written by me as first author.

Göttingen, October, 2015

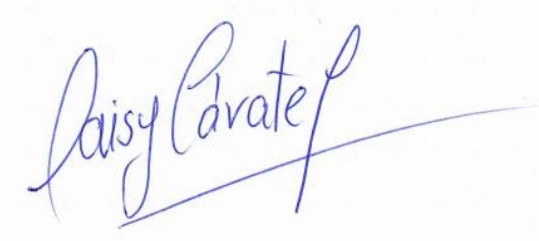

Dayssy Cárate Tandalla 